\title{
Beoordelingen van organisatiekenmerken : een sociaal gezondheidkundige studie naar organisatiekenmerken en ziekteverzuim
}

Citation for published version (APA):

Nijhuis, F. J. N. (1984). Beoordelingen van organisatiekenmerken : een sociaal gezondheidkundige studie naar organisatiekenmerken en ziekteverzuim. [Doctoral Thesis, Maastricht University]. Rijksuniversiteit Limburg. https://doi.org/10.26481/dis.19840524fn

Document status and date:

Published: 01/01/1984

DOI:

10.26481/dis.19840524fn

Document Version:

Publisher's PDF, also known as Version of record

Please check the document version of this publication:

- A submitted manuscript is the version of the article upon submission and before peer-review. There can be important differences between the submitted version and the official published version of record.

People interested in the research are advised to contact the author for the final version of the publication, or visit the DOI to the publisher's website.

- The final author version and the galley proof are versions of the publication after peer review.

- The final published version features the final layout of the paper including the volume, issue and page numbers.

Link to publication

\footnotetext{
General rights rights.

- You may freely distribute the URL identifying the publication in the public portal. please follow below link for the End User Agreement:

www.umlib.nl/taverne-license

Take down policy

If you believe that this document breaches copyright please contact us at:

repository@maastrichtuniversity.nl

providing details and we will investigate your claim.
}

Copyright and moral rights for the publications made accessible in the public portal are retained by the authors and/or other copyright owners and it is a condition of accessing publications that users recognise and abide by the legal requirements associated with these

- Users may download and print one copy of any publication from the public portal for the purpose of private study or research.

- You may not further distribute the material or use it for any profit-making activity or commercial gain

If the publication is distributed under the terms of Article 25fa of the Dutch Copyright Act, indicated by the "Taverne" license above, 


\section{BEOORDELINGEN VAN ORGANISATIEKENMERKEN}

Een sociaal gezondheidkundige studie naar organisatiekenmerken en ziekteverzuim.

$\begin{array}{llllllllllll}P & R & O & E & F & S & C & H & R & I & F & T\end{array}$

ter verkrijging $v a n$ de graad van doctor in de Sociale Wetenschappen aan de R1jksuniversiteit Limburg te Mastricht op gezag van de Rector Magnificus

Prof.Dr. H.C. Hemker, volgens besluit van het College der Dekanen in het openbaar te verdedigen op donderdag 24 me1 1984, des namiddags om vier uur precies in de aula van de universiteit

door

Franciscus Johannes Nicolaas Nijhuis, geboren te Oldenzaal op 5 december 1949 . 
Promotores : Prof.Dr. J.J.C.B. Bremer, Prof.Dr. H. Philipsen,

Referenten: Prof.Dr. Tj. de Boorder, Prof.Dr. Ch.J. de Wolff. 
Het in dit proefschrift beschreven onderzoek is uftgevoerd, als onderdeel van een groter onderzoek naar de relatie tussen organisatiekenmerken en afwezigheid wegens ziekte en mate van uittreding wegens arbeidsongeschiktheid in het Herstructureringsgebied Zuid-Limburg.

Dit onderzoek is uitgevoerd in opdracht van het Provinciale Bestuur van Limburg en met subsidies van het Ministerie van Sociale Zaken en Werkgelegenheld en van Economische Zaken (Perspectieven Nota Limburg gelden). Dit onderzoek is verricht onder begeleiding van een commissie, waarvan de samenstelling in bijlage 1 staat vermeld. 
Administratieve verwerking Omslag Druk
: A. Silanoe-Verweij

: G. van Roolj

: B. Meerstad 


\section{INHOUDSOPGAVE}

Inleiding

1. Ziekteverzuim sociaal-gezondheidkundig bezlen

1.1. Inleiding

1.2. Afwezigheid wegens ziekte als beslissingsmodel

1.2.1. De afwezigheids- en uittredingsnoodzaak

1.2.2. De afwezigheids- en uittredingsgelegenheid

1.2.3. De afwezigheids- en uittredingsbehoefte

1.3. Ziekteverzuim als een sociaal-gezondheldkundig probleem

1.3.1. Algemeen

1.3.2. De sociaal-gezondheldkundige oriëntatle toegepast op ziekteverzuim

1.4. Mogelijkheden voor sociaal-gezondheidkundige interven-

ties

1.4.1. Op individueel niveau: beslissing tot ziekme1ding

1.4.2. Op organisatie niveau: ten aanzien van de organisatiekenmerken

1.4.3. Op structureel niveau: ten aanzien van de structuur van de gezondheidszorg en de soclale wetgeving

2. Organisatiekenmerken en ziekteverzuim

2.1. Inleiding

2.2. Opzet van het onderzoek

2.2.1. Het aantal deelnemende organisaties

2.2.2. Enkele statistische kenmerken van de onderzochte organisaties

2.2.3. De representativiteit van de deelnemende organisaties

2.2.4. De verschillende beoordelaars

2.3. Samenvatting van de belangrijkste resultaten van de relaties tussen de ziekteverzuim- en arbeidsongeschiktheidsindicatoren enerzijds en de organisatiekenmerken anderzijds

2.3.1. Invloed van bezwarende werkomstandigheden

2.3.1.1. Invloed van fysiek bezwarende werkomstandigheden

2.3.1.2. Invloed van laag gekwalificeerde a rbeld 
2.3.2. Invloed van social support

2.3.3. Invloed van de economische situatie van de organisatie

2.3.4. Invloed van personeelsbeleid

2.3.5. Invloed van de factor personeelsbezetting

2.3.6. Invloed van verschillen in arbeidsoriëntatie

2.3.7. Invloed van de grootte van de arbeidsorganisatie

2.4. Probleemstelling

3. Discrepantie als onderzoeksproject

3.1. Inleiding

3.2. Verschiliende benaderingen in het organisatieonderzoek

3.3. Discrepantie: een begripsverheldering

3.4. Theoretische oorzaken voor discrepantie

3.5. De discrepantievariabelen

3.6. De analyse van de discrepantlevariabelen

3.7. De discrepantiemat

3.8. De Multitralt-Multimethod Matrix

4. Organisatilekenmerken en de discrepantievariabelen:

Beschrijuing van de variabelen en de veronderstellingen.

4.1. Inleiding

4.2. Verantwoording van de keuze der variabelen

4.3. Beschrijving van de variabelen

4.4. Hypothesen betreffende discrepantie in de arbeidsorganisatie

5. Discrepantle binnen de werkorganisatie

5.1. De discrepantievariabelen

5.1.1. Statistische kenmerken

5.1.2. De onderlinge relatie tussen de discrepantievariabelen

5.1.3. De relatie tussen de discrepantievariabelen en de arbeldsomstandighedenvariabelen

5.2. De analyse van de discrepantiescores

5.2.1. Inleiding

5.2.2. De analyse 
5.2.3. De analyse van de discrepantie tussen het management en het hoofd personeelszaken

(Dman-pz)

5.2.3.1. De multiple regressie-analyse van de Dman-pz

5.2.3.2. De discriminant-analyse op de Dman-pz

5.2.3.3. Onderlinge relaties tussen de organisatiekenmerken en de interpretatie van de gevonden verbanden

5.2.4. De analyse van de discrepantie tussen het management en de personeelsvertegenwoordiging (Dman-pv)

5.2.4.1. De multiple regressie-analyse van de Dman-pv

5.2.4.2. De discriminant-analyse op de Dman-pv

$5 \cdot 2 \cdot 4.3$. Onderlinge relaties tussen de organisatiekenmerken en de interpretatie van de daartussen gevonden verbanden

5.2.5. De analyse van de discrepantie tussen het hoofd personeelszaken en de personeelsvertegenwoordiging ( $D p z-p v$ )

5.2.5.1. De multiple regressie-analyse van de Dpz-pv

5.2.5.2. De discriminant-analyse op de Dpz-pv

5.2.5.3. Onderlinge relaties tussen de organisatiekenmerken en de interpretatie van de daartussen gevonden verbanden

104 5.2.5.4. Aanvullende analyse betreffende de Dpz-pv

5.3. Samenvattende bevindingen

5.4. Discrepantie en de indicatoren voor verzuim en arbeidsongeschiktheid

5.4.1. Correlaties tussen de discrepantievariabelen en de verzuim- en arbeldsongeschiktheidsindicatoren

5.4.2. Interpretatie van de relaties tussen de verzuim- en arbeidsongeschiktheidsindicatoren en de discrepantiematen

5.4.3. Verzuimindicatoren en organisatiekenmerken

5.4.4. Conclusies ten aanzien van de relatie tussen de verzuimindicatoren en de discrepantievariabelen 
6. Discrepantie-items nader belicht

6.1. Inleiding

6.2. Beschrijuing van de discrepantie-items

6.3. Analyse van de discrepantie-items

6.3.1. Analyse van de discrepantie-items

management-personeels zaken

6.3 .1 .1 . De resultaten

6.3 .1 .2 . Interpretatie van de verschillen tussen beoordelingen tussen het management en het hoofd personeelszaken

6.3.2. Analyse van de discrepantie-items management versus personeelsvertegenwoordiging

6.3 .2 .1 . De resultaten

6.3.2.2. Interpretatie van de bevindingen

6.3.3. Analyse van de discrepantie-items hoofd personeelszaken versus personeelsvertegenwoordiging 6.3.3.1. Analyse-resultaten

6.3.3.2. Interpretatie van de bevindingen

6.4. De Multitrait-Multimethod Matrix

6.4.1. De MTMM-matrices tussen management en hoofd personeelszaken

6.4.1.1. Resultaten

6.4.1.2. Interpretatie van de MTMM-matrix: management versus hoofd personeelszaken

6.4.2. De MTMM-matrices tussen management en personeelsvertegenwoordiging

6.4 .2 .1 . Resultaten

6.4.2.2. Interpretatie van de MTMM-matrix: management versus personeelsvertegenwoordiging

6.4.3. De MTMM-matrices tussen het hoofd personeelszaken en de personeelsvertegenwoordiging

6.4 .3 .1 . Resultaten

6.4.3.2. Interpretatie van de MTMM-matrix: hoofd personee1szaken versus personeelsvertegenwoordiging

6.5. Samenvatting van de analyse van de discrepantie-items 
7. Discrepantie bij de beoordeling van de arbeidsomstandighedenitems

7.1. Inleiding

7.2. De onderlinge relaties tussen de gesommeerde arbeidsomstandighedenscores

7.2.1. De samenhang tussen de gesommeerde materiële en immaterlële arbeldsomstandighedenscores

$7 \cdot 2.2$. Verschillen in gemiddelden tussen de gesommeerde materiële en immateriële arbeidsomstandighedenscores

7.3. Beoordeling van arbeidsomstandigheden en klaaggedrag 141

7.4. Arbeidsomstandigheden per item beschouwd

7.4.1. Verschillen en overeenkomsten tussen de beoordelingen van het management, het hoofd personeelszaken en leden van de personeelsvertegenwoordiging

7.4.1.1. De correlaties nader beschouwd

7.4.1.2. De verschillen in absolute waarden nader beschouwd

7.4.1.3. Interpretatie

7.4.2. Verschillen en overeenkomsten tussen de beoordelingen van management, hoofd personee lszaken en leden personeelsvertegenwoordiging enerzijds en de gemiddelde werknemersbeoordeling anderzijds

7.4.2.1. De correlaties tussen de beoordelaars nader beschouwd

7.4.2.2. De gemiddelden van de verschillende beoordelingen nader beschouwd

7.4.3. Interpretatie

7.5. De Multitrait-Multimethod-Matrix

7.5.1. De MTMM-arbeidsomstandighedenitems-matrices tussen management en hoofd personeelszaken

7.5.1.1. De 'management-matrix'

7.5.1.2. De "personeelszaken-matrix"

7.5.1.3. De onderlinge vergelijking van MTMMarbeidsomstandigheden-matrices

7.5.2. De MTMM-arbeidsomstandighedenitem-matrices tussen management en personeelsvertegenwoordiging

7.5.2.1. De 'personeelsvertegenwoordigingmatrix" 
7.5.2.2. Onderlinge vergelijking van de MTMMarbeidsomstandigheden-matrices

7.5.3. De MTMM-arbeldsomstandigheden-matrix van personeelszaken en personeelsvertegenwoordiging 158 7.5.3.1. De onderlinge vergelijking van de MTMM-arbeidsomstandighedenitemsmatrices

7.5.4. De arbeldsomstandigheden matrix

'gemiddelde werknemersscore'

7.5.4.1. De intrabeoordelaarcorrelatie werknemersscore-matrix

De onderlinge vergelijking van de MTM-arbeldsomstandigheden-matrices

7.5.4.2.

7.6. Samenvatting van de bevindingen

8. Discrepantie en concordantie nader beschouwd

8.1. Inleiding

8.2. Relevantie van de bevindingen

8.2.1. Organisatiekenmerk of statistisch artefact

8.2.2. Implicaties voor organisatie-onderzoek

8.2.3. Implicaties voor interventies

8.3. Bronnen van discrepantie

170

8.4. Afsiulting

Samenvatting

Summa ry

Literatuurli jst

B1jlagen

Nawoord 
De bevinding dat Zuid-Limburg een specifiek regionaal ziekteverzuimpatroon kent, vormde een aanlelding om onderzoek te doen naar de condities in arbeidsorganisaties, die van invloed zijn op de mate waarin werknemers afwezig zijn wegens ziekte of op de uittreding uit het arbeidsproces middels WAO of IP (Invaliditeitspensioen).

Bij de opzet van dit onderzoek naar de relatie tussen organisatiekenmerken enerzijds en arbeidsongeschiktheidsindicatoren anderzijds werd het zowel door de onderzoekers, als door de begeleidingscommissie noodzakelijk geacht on bij het meten van organisatiekenmerken gebruik te maken van meerdere categorieën informanten.

De veronderstelling daarbij was dat werknemers en de personeelsvertegenwoordiging anders tegen eenzelfde arbeidsorganisatie aankijken als het management of het hoofd personeelszaken. Dientengevolge zouden tussen het management en het hoofd personeelszaken, maar ook tussen werknemers en personeelsvertegenwoordiging verschillen in beoordeling plats kunnen vinden. Deze veronderstelling bracht de onderzoekers ertoe om bepaalde vragen aan verschillende categorieën beoordelaars te stellen. Met name is daarbij uftgegaan van vragen met betrekking tot kenmerken van de organisatie of van de arbeidssituatie.

Tijdens de uitwerking van de interviews, welke aan de hand van voorgestructureerde vragenlifsten hebben plaatsgehad, bleek dat op sommige vragen de antwoorden van de respondenten strijdig waren met elkaar. Zo constateerden we tussen bepaalde categorieën beoordelaars verschillen in de beantwoording van de vraag naar het hanteren van beoordelingssystemen in de betreffende arbeidsorganisatie. Dergelijke salllante verschillen maken vaak meer indruk op de warneming van de onderzoeker, dan een groter aantal malen dat overeenkomsten gevonden worden.

Vandaar dat de vraag rees of deze verschillen reëel waren, dat wil zeggen bij statistische toetsing significante afwijkingen van het gemiddelde te zien zouden geven. Met andere woorden of we hier slechts met een onderzoekersvertekening te maken hadden, danwel met een werkel $1 \mathrm{jk}$ bestaand organisatiefenomeen.

Deze vragen werden versterkt doordat de auteur vanuit vroegere contacten met vakbondskaderleden in bedrifven regelmatig geconfronteerd is met onderlinge discrepanties, die voor een deel voortspruiten uit verschil in Informatie, ult verschillende groepsbelangen of uit verschillende posities in organisaties. 
Bovendien werden deze vragen versterkt door het felt dat vanuit organisatieveranderingsperspectlef regelmatig gemeld wordt dat bepalde veranderingen, c.q. interventles (Bagchus, 1982) niet die vruchten arterpen, die daarvan verwacht werden. Als een van de oorzaken is hiervoor aan te merken dat binnen organisaties verschilende groepen verschillende doeleinden nastreven (verborgen agenda"s) ten aanzien $v$ an de geperclpleerde noodzakelijke veranderingen. Ook hier blijken verschillen in beoordeling een heel belangrijk element.

Vandaar dan ook dat, naast de relatie tussen arbeidsongeschiktheidsindicatoren en organisatiekenmerken, een tweede probleemstelling naar boven kwam, uitmondend in de vragen:

- Z1jn er verschillen in beoordeling wan organisatiekenmerken door management, personeelszaken of personeelsvertegenwoord1ging? Zo ja,

- Vormen deze verschillen een specifiek organisatiekenmerk, dat wil zeggen hangen zij samen met andere organisatievariabelen? Zo ja,

- Ten aanzien van welke organisatieaspecten worden deze discrepantles dan gevonden en ten aanzlen van welke organisatieaspecten bestaat de nodige mate van overeenstemming?

Het zijn deze vragen die de inspiratiebron vormden voor deze dissertatie.

De eerste 2 hoofdstukken zullen een neerslag zijn van de gevonden relaties tussen arbeidsongeschiktheidsindicatoren en organisatiekenmerken. Deze relaties kunnen slechts tot interventie leiden, indien duidelijk is dat de organisatiekenmerken een getrouwe weergave zijn van de beoordeling van de arbeldssituatie, ofwel indien duidelijk is in welke opzichten de verschillende groepen in de organlsatie verschillende beoordelingen hanteren van organisatiekenmerken en daarmee impliclet van organisatieproblemen. 
HOOFDSTUK 1. ZIEKTEVERZUIM SOCIAAL-GEZONDHETDKUNDTG BEZIEN

1.1 .

Inleiding

Gegevens over ziekteverzuim halen met grote regelmat de landelijke media, dit in tegenstelling tot andere vergelifkbare fenomenen zoals het aantal persoonlijke ongevallen in de bedrijfssituatie, ontwikkelingen in het doktersbezoek en de mate (kwantitatief) waarin bezwarende werkomstandigheden voorkomen. Blijkbaar fungeert het ziekteverzulmpercentage -evenals het werkloosheidspercentage- als een indicator voor het rellen en zellen in het Nederlandse bedrijfsleven. Het zlekteverzuimpercentage $1 \mathrm{jjkt}$ een betrouwbaar gegeven, dat wil zeggen: het zlekteverzulmpercentage is een maat die goed registreerbaar is en die tegelifkertijd een indicator is voor de kwalitelt van de arbeld en arbeidsomstandigheden in de Nederlandse Industrle. Dit fungeren als indicator kan slechts indien het ziekteverzulmpercentage (meer of minder gemakkelijk) beInvloedbaar is, een maat die over een groot aantal jaren constant is, kan namelijk niet dienen als indicator voor het effect van sociaal-economische en bedrijfsorganisatorische veranderingen op het individu. Ook in dit opzicht vertoont zij een overeenkomst met het werkloosheidspercentage. Bovendien zijn de financiële kosten zowel van werkloosheld als van zlekteverzulm en arbeidsongeschiktheid zeer hoog.

Een laatste hier te noemen punt van overeenkomst is dat zowel het zlekteverzuimpercentage, als het werkloosheidspercentage indicatoren vormen voor ongewenst, te vermijden gedrag (werkloos-zijn en ziek zijn), dat afwijkt van het 'ideaal'-beeld van het individu In de moderne westerse samenleving.

Het is dan ook nlet vreemd dat zlekteverzulm al sinds zeer lange tijd object van studie is binnen de sociale wetenschappen. Ziekteverzuim wordt binnen deze wetenschappen bestudeerd op versch11lende wijzen en met verschillende doelstellingen, namelijk:

1) Ziekteverzuim als individueel te beinvloeden gedrag. onder deze noemer valt onder andere: onderzoek naar het effect van verschillen in riskante leefgewoonten op het zlekteverzuimfrequentie (Philipsen, 1977), onderzoek naar verschil in individuele ziektekans en lichamelijke gesteldheid (semmence, 1971), onderzoek naar persoonlijkheldsfactoren, gedrags- en motivatieaspecten in relatie tot zlekteverzuim (Chadwick-Jones e.a., 1973; Ilgen en Hollenback, 1977; Muchinsky, 1977; Steers en Rhodes, 
1978), onderzoek naar zogenaand onelgenlijk gebruik van de ziektewet ("baaldagen') en de benadering van verzuim als "protest" van de werknemers tegen de kwalitatief slechte arbeldssituatie (Kulper, 1980).

2) Ziekteverzuim in relatie met organisatiekenmerken.

Deze studies hebben vooral tot doel om te ontdekken welke faktoren in de arbeldssituatie ziekte- en arbeldsongeschiktheidsbevorderend $z 1 j n$, of ertoe leiden dat sneller, c.q. langduriger ziekmelding platsvindt. Veelal worden deze studies vanuit de arbelidsorganisaties geëntameerd, omdat ziekteverzuim direkt negatieve consequenties heeft voor de (organisatie van) de productie. Deze studies vormen dan vaak aanzetten om te komen tot verbeteringen in de arbeldssituaties (Philipsen, 1969a; Ris, 1978).

3) Ziekteverzuim in relatie met maatschappelijke context-variabelen.

3a) Ziekteverzuim in relatie met conjunctuur.

Hferonder valt bijwoorbeeld de relatie tussen ziekteverzuim en de conjuncturele schommelingen. Zo stelt bijvoorbeeld Behrend (1953), dat de angst voor werkloosheid de belangrijkste prikkel is om het ziekteverzuim te verminderen. Ook in Nederland is het verband tussen ziekteverzuim en conjunctuur object van onderzoek geweest (Buringh, 1977a en b en Kruidenier, 1981, 1983; Smulders e.a., 1983; Smulders, 1983; N1jhuls, 1983).

3b) Zlekteverzuim in relatie met de structuur van de gezondheidszorg.

Bekend is dat zowel de structuur van de gezondheidszorg alsook de sociale wetgeving een duurverlengende invloed op het verzuim kunnen hebben (Tordolr e.a., 1978; Soeters, 1983a, 1983b).

3c) Ziekteverzuim vanuit economisch perspectief.

Voorop staan de maatschappelijke kosten, die een hoog zlekteverzuim met zich meebrengt. Deze kunnen zowel uitgedrukt worden in:

- kosten ten behoeve van loondervingsregelingen,

- kosten vanwege verminderde productivitelt.

Deze yerschillende benaderingen kunnen niet in zijn geheel als onafhankelijk van elkaar gezlen worden. Ondanks hun verwevenheid is het toch noodzakelijk deze verschillende benaderingen van zlekteverzuim te onderscheiden. Immers onder de aanname dat 
zilekteverzuim een te vermijden of althans een te beperken grootheld is, blijken deze verschillende visies op de oorzaken van een "te" hoog zlekteverzulm tot verschillende "oplossings"-strategieën te leiden.

Indien de oorzaken voor ziekteverzuim in de eerste plaats bij het individu gezocht worden (bijvoorbeeld gebrek aan motivatie, gebrek aan plichtsbetrachting, vermindering van het arbeldsethos, een neer instrumentele werkbinding), dan zal het effect zijn dat interventies eveneens gericht zullen worden op het individuele niveau. Hierbij kan zowel gedacht worden aan strengere controle en toepassing van sancties, als aan motiverende en de werkbinding bevorderende acitviteiten. Met het opsporen van individuele kenmerken die bepalend zijn voor een hoger verzuim wordt eveneens de oplossing van de ziekteverzulmproblematiek op het niveau van het individu gedefinieerd.

Organisatieonderzoek naar kenmerken van de arbeldssituaties die de verzuimfrequentie en -duur beinvloeden zal ertoe leiden dat interventies ook op organisatieniveau gezocht zullen worden. En waar uit onderzoek blijkt dat de structuur van de gezondheldszorg een duurverlengende invloed op het ziekteverzuim heeft, daar zullen beperkende matregelen op het terrein van de gezondheidszorg ontwikkeld worden.

Deze verschillende benaderingswijzen en de daaraan inherente interventies gaan uit van de aanname dat, waar ook de bron van een hogere gemiddelde verzuimfrequentle of van een langere gemlddelde verzuimduur gelegen moge zijn, op individueel niveau de gezondheidstoestand niet in alle gevallen zo dwingend is dat zij de afwezigheld wegens ziekte voor $100 \%$ dicteert. Er wordt derhalve verondersteld dat er een marge 1 s warblnnen de werknemer, c.q. de gezondheidszorg speelruimte heeft om zich-bij een bepaalde mate van arbeidsongeschiktheld- al dan niet (nog) af te melden wegens zlekte.

1.2 . Afwezigheid wegens ziekte als beslissingsmodel

Deze beslissingsvrijheid is door Philipsen (1969a) -voortbouwend op De Groot (1958) - benoemd in drie te onderschelden elementen, te weten de afwezigheidsnoodzaak, de afwezligheidsgelegenheid en de afwezigheidsbehoefte. Deze driedeling is eveneens van toepassing op de toetreding tot de WAO (De Jong e.a., 1981; N1jhuis en Soeters, 1982), al moet daarbij gesproken worden van ulttredingsin plaats van afwezigheidsaspecten. In de volgende beschrijuing 
zullen wij ons wooral baseren op Philipsen (1969a) en De Jong e.a. (1981), daarb1j grotendeels de $11 \mathrm{jn}$ volgend van N1jhuis en Soeters (1982). Daarbif zal een beperking plaats hebben tot de factoren, die op organisatieniveau de afwezigheids- en uittredingsnoodzaak, -gelegenheid en -behoefte beinvloeden. Persoonlifke factoren, zoals de individuele lichamelijke gesteldheid, de belasting buiten het werk, versch1llen in individuele belastbaarheld en dergelijke, worden hier buiten beschouwing gelaten.

\subsubsection{De afwezigheids- en uittredingsnoodzaak}

Arbeldsorganisatles verschillen in de mate waarin zlekte, c.q. aandoeningen gecreëerd worden of voorkomen en de mate waarin $z i j$ afwezigheid wegens ziekte trachten te verminderen. Ten aanzien van de afwezigheids- en uittredingsnoodzaak zijn de volgende factoren te noemen:

- arbeidsomstandigheden.

Deze kunnen per organisatie verschillen; enerzijds zijn er verschillen in de mate waarin arbeldsomstandigheden relatief lichte aandoeningen veroorzaken, anderzijds in de mate, waarin de arbeldsomstandigheden bij relatief lichte aandoeningen of bij beperkte handicaps de continuering van het werk bemoeilijken.

Het betreft hier arbeldsbelasting in de meest ruime zin des woords, variërend van fysisch-chemische omstandigheden tot taakkenmerken en kenmerken van de werksfeer (stressoren).

- mogelijkheden tot aangepaste arbeid.

organlsaties kunnen variëren in de mate waarin aanwezigheid van passende arbeld voor gedeeltelijk gehandicapten binnen de organisatie mogelijk 1s. Deze factor is niet alleen van belang in verband met de uittredingsnoodzaak, maar voorzover het tijdelijk aangepast werk betreft, ook in verband met de afwezigheidsnoodzaak.

- leeftijasopbouw.

De leeftijdsopbouw van het personeelsbestand kan per organisatie verschillen. Naarmate er meer oudere werknemers in een organisatie werkzaam zijn, zullen meer ernstige aandoeningen en meer beperkingen in de arbeldsgeschiktheid voorkomen.

- selectie op zlekterisico.

Al naar gelang de aard van het wervings- en selectiebeleid van de organisatie is het mogelijk dat die betreffende organisatie meer of minder selecteert op het ziekterisico van werknemers. Verder kan ook de aard van het personeelsbeleid in algemene zin 
voorkomen of tenminste vroegtijdig signaleren, dat problemen in de mens-werk-relatie ontstaan.

\subsubsection{De afwezigheids- en uittredingsgelegenheid}

De mogelijkheden die werknemers hebben bij een ziekte of handicap ook daadwerkelijk te verzuimem totdat herstel is opgetreden, kan per bedrijf en per werkaktiviteit verschillen.

Deze mogelijkheden worden belnvloed door:

- de onmisbaarheid.

Een eerste factor met betrekking tot de afwezigheids- en uittredingsgelegenheid betreft de onmisbaarheid van het personeelslid in kwestie. Indicatief hiervoor kan de mate zijn waarin in de personeelsbezetting van de organisatle is voorzien en bovendien, de manier, waarop men de afwezigheid van een zlek personeelslid op zijn werkplek opvangt. Een ziektemelding in een Eenmansbedrijf heeft uiteraard andere consequenties dan een zlektemelding in een groot industrieel concern, waar men reserves in het personeelsbestand heeft ingecalculeerd. Bovendien kan het bestaan van een intensief begeleidingsbeleid ten aanzien van zieke personeelsleden erop duiden, dat de werknemers relatief minder goed misbaar $z i j n$ voor een goede voortgang van het werkproces. Deze indicatoren zeggen lets over de onmisbaarheid van het personeel en zijn daarmee (mede) bepalend voor de afwezigheids- en uittredingsgelegenheid.

- (mogelijke) sancties op afwezigheid wegens ziekte. Bij de toepassing van sancties in deze zijn een drietal verschillende mechanismen te onderscheiden:

- In de eerste plaats zijn de uitkeringsvoorwaarden van belang. Naarmate bij afwezigheld wegens zlekte een grotere inkomensachteruftgang direct of in de nabije toekomst te verwachten is, dan zal waarschijnlijk de afwezlgheld wegens ziekte en arbeldsongeschiktheid geringer zijn.

- Ten tweede speelt in dit verband de wijze van afwezigheidscontrole een rol. Organisaties kunnen in dit opzicht van elkaar verschillen. Deze controle kan bijvoorbeeld plaats hebben vanuit de organisatie zelf, maar kan ook gebeuren vanuit de bedrijfsvereniging.

- Ten derde kan de mate van werkzekerheld van belang zijn; daarbij speelt de sociaal-economische positie van de organisatie een belangrijke rol. Frequente of langdurige afwezigheid wegens ziekte kan lelden tot een, objectief of subjectief, vergrote kans op ontslag bij mogelijke inkrimping. 
- woonplaats van het personeel.

Naarmate de personeelsleden meer in stedelfjke milieus wonen, zal het mechanisme der sociale belnvloeding minder sterk zijn. Dientengevolge 18 vernoedelijk zowel de afwezigheildsgelegenheid als de uittredingsgelegenheld groter. Voorzover er sprake is van sociale belnvloeding vanult het verstedelijkt woonmilieu op afwezigheid wegens ziekte en arbeidsongeschiktheid, zal dit eerder een verhogend dan beperkend effect hebben. In het algemeen wordt in verstedelijkte woonmilieu's namelijk een ruimere ziektedefinltie gehanteerd. Zlekte- of arbeldsongeschiktheidsgevallen zullen daarom minder snel als een afwijking van de norm worden beschouwd.

1.2.3. Afwezigheids- en ultcredingsbehoefte

Naarmate in een organisatie de arbeid meer in overeenstemming met de verlangens van de werknemers georganlseerd 1s, zal de afwezigheids- en uittredingsbehoefte kleiner $z 1 j n$. De belangrijkste belnvloedende factoren hlerbij zijn:

- de bindingskracht van het werk of de organisatie.

De ulttredingsbehoefte zal geringer zijn, indien een organisatie zijn werknemers meer weet te binden, bijvoorbeeld door middel van:

- een grote mate van identificatie,

- extrinsieke lokmiddelen (carrière-perspectief, secundaire arbeidswoorwaarden, beloning),

- intrinsieke bindmiddelen (regelcapaciteit (De Sitter, 1981), discretie, verantwoordelijkheid, zelfontplooling, medezeggenschap),

- arbeldsomstandigheden.

Ongekeerd kunnen werkomstandigheden dermate eentonig en weinig uitdagend zijn en/of Intrinslek of extrinsiek zo weinig motiveren, dat de nelging tot vermijding van het werk, tot afwezigheldsbehoefte groot is.

Gesteld kan worden dat het individu bif elke vorm van verminderde arbeidsgeschiktheld een beslissing moet nemen ten aanzien van werkcontinuering of werkhervatting. Dit betekent echter geenszins dat strategleën om verzuim te verminderen op individueel niveau gevoerd dienen te worden, maar wel dat het in latste instantie het Individu zelf is die, al of niet op advies van anderen, beslist tot of kiest voor (continuering van) afwezigheld wegens ziekte. 
Deze conclusie maakt beinvloeding van de hoogte van het ziekteverzuim mogelijk. Zou deze individuele afweging geen rol in het verzuimproces spelen dan zou de beinvloeding van afwezigheld wegens zlekte uitsluitend kunnen verlopen middels het aangrijpen van de directe oorzaken van verzuim. Slechte arbeidsomstandigheden kunnen een legitieme grond vormen voor afwezigheid wegens ziekte, echter meestal zullen zij geen directe ziektebron zijn, althans voor wat betreft de lichamelijke ziekten.

1.3. Ziekteverzuim als een sociaa1-gezondheidkundig probleem

1.3.1. Algemeen

Ziekteverzuim, arbeidsverzuim wegens ziekte is een onwenselijke, te vermijden toestand. Soclaal-gezondheldkundig is ziekteverzulm bestuderenswaard, omdat het zowel een indicator voor de aantasting van het gezond bestaan als door middel van interventies in zijn omvang beinvloedbaar is. Het hiervoor geschetste beslismodel makt het mogelijk om op verschillende niveau's interventiemogelijkheden te postuleren:

- op het niveau van het individu

- op het niveau van de organisatie

- op het niveau van de gezondheidszorg en de sociale wetgeving. Volgens Philipsen (z.j.) berust het sociaal-gezondheidkundig denken op een drietal pijlers, te weten: 'het gezonde bestaan', 'bedreigende en begunstigende factoren" en 'interventies'. Het zijn vooral deze relaties die binnen de soclaal-gezondheidkundige visie de aandacht krijgen. Philipsen bouwt hierbij voort op Kuiper (1975), die stelt dat de gezondheidkundigen gericht $z 1 j n$ op het herkennen van bedreigingen van het gezonde bestaan (begunstigende en bedreigende factoren) en het ellmineren daarvan (interventies) in het belang van concrete subjecten (het gezonde bestaan).

Toegepast op afwezigheld wegens zlekte levert een dergelijke benadering de in figuur 1 gegeven, beschrijving op (zie ook: Schets voor de oprichting van ARBO-instituten, 1982). 
Figuur 1: De centrale concepten binnen de soclaal-gezondheldkundige orlentatie.

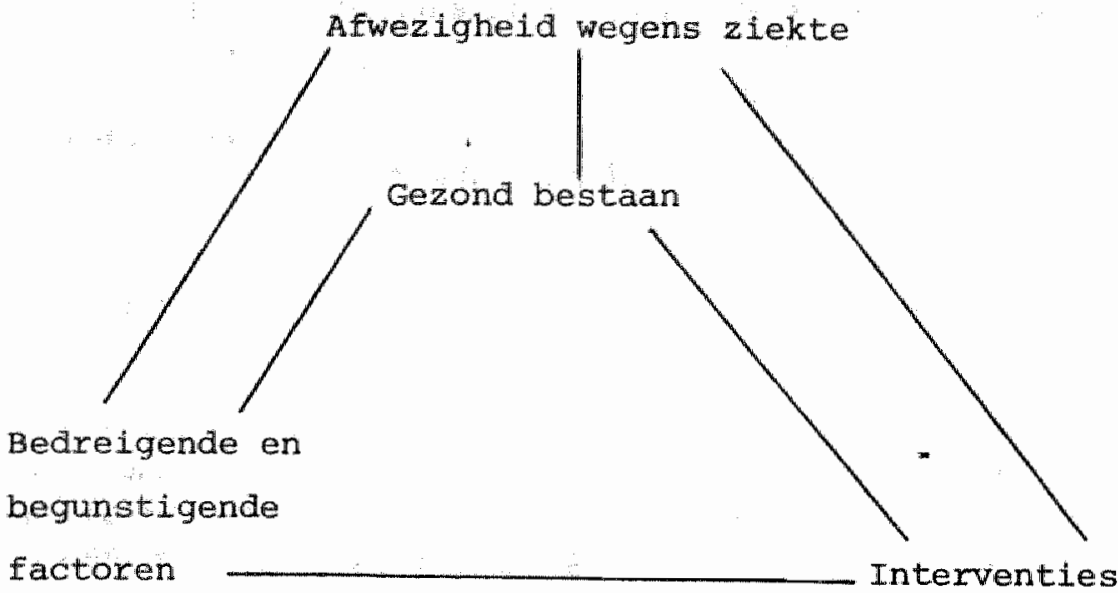

De concepten 'gezond bestaan', 'bedreigende en begunstigende factoren" en "Interventies" vormen niet meer dan een globaal analyseschema. Door middel van deze concepten worden de relaties verhelderd die centraal staan in het soclaal-gezondheldkundig onderzoek. Het is evident dat het gewicht dat aan de verschillende relaties moet worden toegekend ongelijk is. Zo zal het gezond bestaan sterker belinvloed worden door de bedreigende en begunstigende factoren dan dat het direct beinvloed wordt door interventles. Interventies zullen veelal gericht zijn op de vermindering van bedreigende en bevordering van begunstigende factoren.

Toegepast op afwerigheid wegens ziekte moet geconstateerd worden dat de afwezigheid wegens ziekte direct beinvloed kan worden: -door het gezond bestaan, bijvoorbeeld verzulim ten gevolge van een hartinfarct, -door bedreigende en begunstigende factoren, bijvoorbeeld doordat de arbeldsomstandigheden het werken met een ' 11 chte" kwaal onmogelijk maken,

-door interventles, bijvoorbeeld door strengere controle, op aanwijzing door de verzekeringsgeneeskundige.

Binnen de soctaal-gezondheldkundige benadering wordt geprobeerd deze driehoek in haar geheel te bekijken, omdat er sprake is van een complexe samenhang. Alvorens ons specifiek op de sociaal- 
gezondheldkundige analyse van 'Afwezigheid wegens ziekte' te richten zal ingegaan worden op de algemene begrippen zoals deze in figuur 1 voorkomen.

gezond bestaan:

Gezond bestaan omvat meer dan ultslultend fysische en psychische gezondheld. Dit veelomvattende begrip plaatst het welbevinden van het individu als psychosomatische eenheid in relatie met hem omringende- tijd, plaats en cultuur.

Het begrip 'gezond bestaan' is dan ook geen absoluut begrip en het kan slechts gedefinieerd worden in zijn bloculturele en historische context. Het antwoord op de vraag wat gezond bestaan is, verschilt tengevolge van individuele percepties, door tijden heen, door de levensfase waarin iemand verkeert, en dergelijke. bedreigende en begunstigende factoren:

Er is een aantal factoren dat onder bepaalde omstandigheden direct schadelijke effecten hebben op de fysieke gezondheld, andere factoren hebben dat effect pas op langere termijn.

De invloed van bedreigende en begunstigende factoren op het gezond bestaan als geheel heeft echter een meer diffuus karakter. Wel kan gesteld worden dat onder zeer nauw omschreven omstandlgheden bepaalde factoren spectfieke effecten sorteren op aspecten van het gezond bestaan; maar daar het gezonde bestaan slechts begrepen kan worden in relatie tot zijn totale 'Umwelt' zullen, zeker binnen de arbeidssituatie, grote verschillen bestaan in de mate, waarin bepaalde individuen specifieke factoren als begunstigend of bedreigend voor het gezond bestaan ervaren.

interventies:

Interventies zullen in de regel het gezond bestaan belnvioeden, door de bevordering van begunstigende en de vermindering van bedreigende factoren. Dit kan zowel door middel van preventieve als curatieve activiteiten.

1.3.2. De sociaal-gezondheidkund1ge orlëntatle toegepast op ziekteverzuim

In dit hoofdstuk hebben wij tot nog toe een drietal elementen genoemd die meespelen in het besilssingsproces om bij een ziekte/aandoening over te gaan tot of voort te gaan met afwezigheld wegens ziekte.

Deze drie elementen waren: de afwezigheldsnoodzaak, -gelegenheld en -behoefte.

Vanuit de sociaal-gezondheldkundige optiek is het belangrijk om te zlen dat het genoemde besilssingsproces ook belnvloed wordt 
door:

a. de perceptie van het gezond bestaan

b. de bedreigende en begunstigende factoren

c. de interventies.

De afwezigheldsnoodzaak kan direct belnvloed worden door de bedreigende en begunstigende factoren in de werksituatie. De afwezlgheldsnoodzaak kan eveneens direct beinvloed worden door het scheppen van meer begunstigende arbeidsfactoren (door het plegen van interventies).

Deze relatie zal echter meestal een indirect karakter hebben; de Individuele perceptle van het gezond bestaan en de mate waarin geoordeeld wordt, dat dit gezond bestaan bedrelgd wordt door bijvoorbeeld de arbeldssituatie, zal leiden tot verzulm. Ook voor zover aanpassingen tot stand komen om het verzuim te beperken, zullen de effecten daarvan afhankelijk zijn van de mate warin geperclpleerd wordt, dat deze interventies een bijdrage leveren aan de verbetering van het gezond bestaan.

De afwezigheldsnoodzaak kan gezien worden als het resultaat van een weging die wordt aangebracht om te beslissen of bepaalde omstandigheden zo zijn dat zij tot een aanvang of continuering van afwezlgheid wegens ziekte moet leiden. Ook bij de afwezigheidsbehoefte en blj de afwezlgheidsgelegenheld spelen deze wegingsprocessen een rol en wel ten aanzien van de geschatte voor- en nadelen van verzuim wegens zlekte. Hierbij heeft de afwezigheidsbehoefte voora1 betrekking op de mate waarin begunstigende aspecten in de werksituatie ontbreken. De afwezigheidsgelegenheid heeft vooral betrekking op het aspect van interventles en het ontbreken van negatleve gevolgen van afwezigheld wegens ziekte.

Grafisch is dit weergegeven in figuur 2. Hierbij heeft de stress-cyclus, zoals deze ontwikkeld is door Van Bastelaer en Van Beers (1982) op basis van Katz en Kahn (1978), als basis gediend. 
Figuur 2. Het beslissingsmodel tot ziekmelding of continuering ervan.

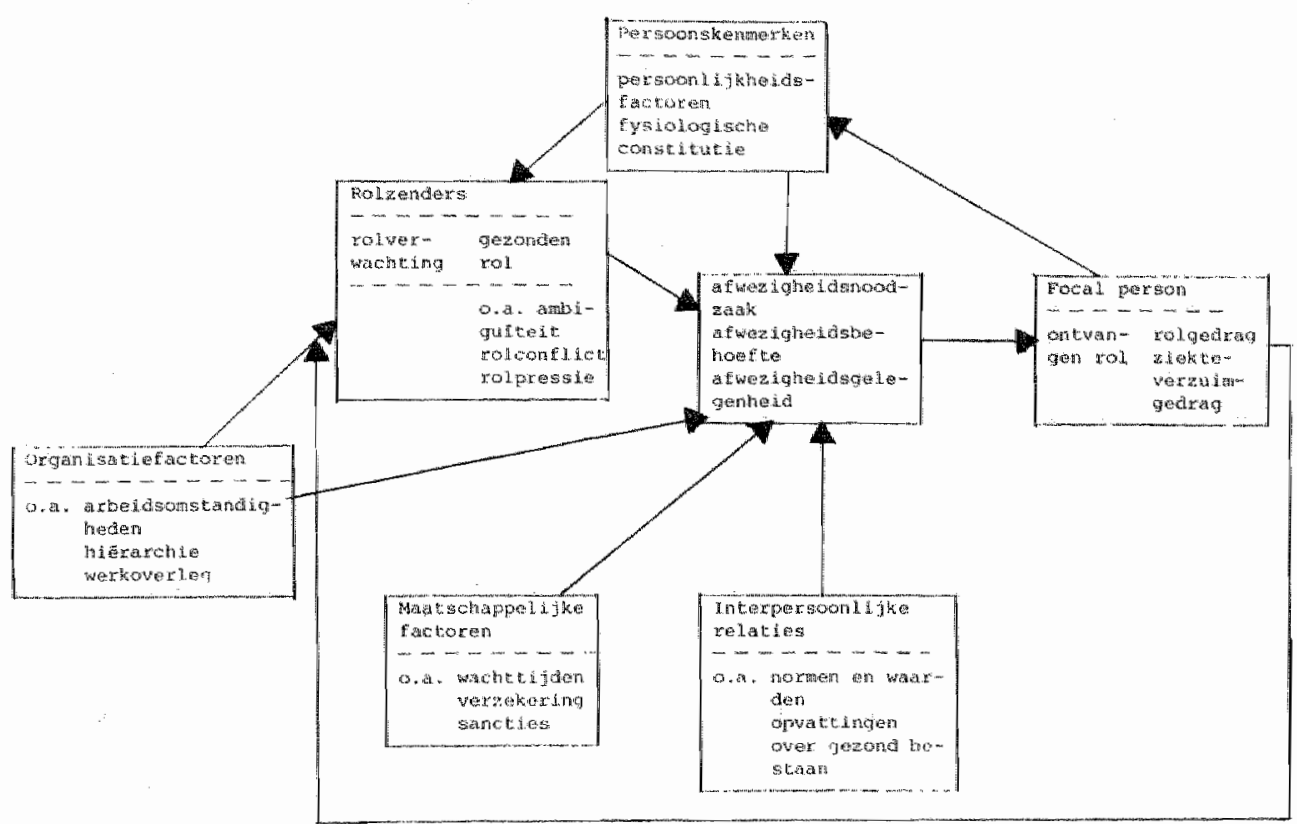

Aan de hand van dit beslissingsmodel kan geconcludeerd worden, waar -althans theoretisch- mogelijkheden bestaan om zo te interveniëren dat het ziekteverzuim af gaat nemen. De afwezigheldsnoodzaak, -behoefte en -gelegenheld wordt volgens dit schema belnvloed door de positie van lemand in de organisatie, door de objectieve arbeldsomstandigheden, door waarden- en normenpatronen ten aanzlen van zowel de (on)geoorloofdheid van verzulm, als van 'gezondheld', door persoonskenmerken en door matschappelijke factoren. Het gewicht van de versch1liende aspecten kan per organisatie en per regio verschillen. 
1.4. Mogeli jkheden voor sociaal-gezondheidkundige interventies

In deze paragraaf zullen wij de belangrijkste soclaal-gezondheidkundige aspecten, die een rol spelen bij afwezigheld wegens ziekte, de revue laten passeren (verg. Prins en Velthuijsen, 1979; Van Putten e.a., 1982). Hierbij dient in gedachten gehouden te worden dat afwezigheid wegens ziekte altijd op individueel niveau geëffectueerd wordt. Het individu neemt de beslissing tot ziekmelding. In veel gevallen is het niet een enkele factor die bijdraagt tot het verzuim. Het negatief doorslaan van de draagkracht-draaglast balans zal beInvloed worden door aspecten van het individu, door aspecten van het werk en door aspecten buiten het werk (sport, (vrijwilligers)werk, huishoudelijke arbeid, relationele problemen, de directe sociale omgeving, etc.) (Zielhuis, 1973; Ettema, 1973; Bremer, 1983). Hoe belangrijk deze latste factor ook is, toch zullen wij daarop niet verder ingaan, omdat dit -vanuit de werkorganisatie gezien- de minst beinvloedbare factor is. Wij zullen hier op een drietal belangrijke -door of vanuft de werkorganisatie beinvloedbare- elementen ingaan.

1.4.1. Op individueel niveau: de beslissing tot ziekmelding

Het individu beslist in welke mate de gegeven omstandigheden (bedreigende en begunstigende factoren en de interventies) een bedrelging vormen voor zijn gezond bestaan. In een aantal gevallen zal deze beslissingsvrijheld nihil zijn: de aandoening makt werken onmogelijk. In andere gevallen zal de aandoening echter minder dwingend zijn en moet het individu op basis van onder andere de gepercipieerde ernst van de aandoening en van de belasting binnen de werksituatie besilssen tot verzuim wegens ziekte of niet. Een dergelijke beslissingsvrijheid makt evenzeer het fenomeen van "doorwerken bij ziekte" mogel1jk.

Bif dit beslissingsproces spelen een veelheid van factoren een rol, zoals de individuele persoonlijkheidsstructuur, individuele en soclaal-culturele opvattingen ten aanzien van ziekte en ziekteverzulm, de soclale omgeving, de geschatte voor- en nadelen van afwezigheld wegens ziekte, de belasting in de werksituatie en de eigen belastbaarheid. In deze benadering past ook de benadering van De Jongh-Hylkema (1973) die naast de term zllekteverzulm voor het 'gedwongen' verzuim ook de term matschappelijk verzuim zou willen invoeren. "Maatschappeli jk verzuim is dat verzuim dat niet veroorzaakt wordt door zlekte in strikt medische zin, maar door 
maatschappelijke factoren, hetzij direct, hetzlj indirect, namelijk door beinvloeding van de instelling van de betrokkenen'. Indien de beinvloeding van de beslissing tot ziekmelding op individueel niveau gezocht wordt, dan kunnen interventies onder andere tot doel hebben om:

- het ziekteverzuim van een negatief stempel te voorzien,

- het sociaal waarden- en normenpatroon (de arbeldsmoraal) te be:nvloeden,

- de individuele binding aan de arbeldsorganisatie te bevorderen,

- ideeën over het gezond bestaan te belnvloeden,

- op individueel niveau de nadelen van afwezigheld wegens ziekte groter te maken dan de voordelen.

Voorbeelden hiervan zijn de vergroting van de individuele nadelen van ziekte, door beperkingen van de uitkeringen bij ziekte, het invoeren van baaldagen, van wacht-dagen, versterking van de contrôle. Zo wordt in 'De Werkgever' (1972) de toenmalige staatssecretaris van sociale zaken, Mr. J. Rietkerk, geciteerd die pleit voor het daadwerkelijk toepassen van wachtdagen en 'aangesjorde' contróle, vanuit de motivering dat mensen het nu eenmaal niet zonder controle kunnen stellen. Deze matregelen zijn echter vooral effectief voorzover er sprake is van een overschot op de arbeidsmarkt. Organisaties kunnen bij krapte op de arbeldsmarkt niet tot dergelijke matregelen overgaan, omdat deze matregelen mogel1jk een groter verloop van arbeldskrachten zullen bevorderen (het ontlopen van sancties), en de aantrekkingskracht van de arbeidsorganisatie op de arbeldsmarkt zal verkleinen. Het is dan ook niet vreemd dat bij het huidige toenemend overschot op de arbeidsmarkt geconstateerd wordt dat de zlektewet-controle door de verzekeringsarts en de zeer algemene soclale controle ten opzichte van ziekteverzuim in de afgelopen 2 a 3 jaar sterk is toegenomen (Smulders e.a., 1983).

1.4.2. Op organisatieniveau: ten aanzien van de organisatiekenmerken

Hierbij moet opgemerkt worden dat organisatiekenmerken op twee manieren het proces van afwezlgheld wegens ziekte kunnen beInvloeden enerz1jds omdat er mogel1jk een directe relatie bestat met het gezond bestaan, anderzijds omdat bepaalde aspecten van de werkorganisatie verzuimbevorderend of verzuimbeperkend $z 11 \mathrm{n}$. Indien de bron voor verzuim in de arbeidsorganisatie gezocht wordt zullen interventies vooral gericht zijn op de arbeldssituatie en de kenmerken van de arbeidsorganlsatles. 
Bekend is dat elke werkorganisatie zijn elgen patroon van afwezigheid wegens ziekte bezit, dat het afwezigheldspatroon van een bepalde arbeldcorganisatie systematisch en bij voortduring afwijkt van de afwezigheidspatronen van andere organlsaties (Philipsen, 1969a). Het, in hoofdstuk 2 beschreven, onderzoek van Nijhuis en Soeters (1983) heeft deze stelling tot ultgangspunt. De hisergenoemde organisatiegewijze verschillen in zlekteverzuimpatronen blijken voor een groot deel te verklaren te zijn met behulp van kenmerken van de organisatle zelf. Deze organlsatiekenmerken verklaren overigens niet de hoogte van het zlekteverzuim in een organlsatie, maar wel de verschillen in ziekteverzuim tussen organisaties. Het 'basis-percentage' waarin arbeidsorganisaties overeenkomen wat betreft zlekteverzuim, wordt in dit soort onderzoek niet verklaard. Per organisatie kunnen zodoende de 'verzuimbevorderende' aspecten worden opgespoord. Indien aan verzuimbestrijding binnen de organisatie gedaan gat worden moet dit met name leiden tot veranderingen ten aanzien van deze verzuimbevorderende aspecten. Soortgelijke benaderingen worden ook teruggevonden bij van Putten e.a., 1982; Ris, 1978; Draalsma en Smulders, 1978; Smulders, 1980; Den Hartog, 1982).

1.4.3. Op structureel niveau: ten aanzien van de structur van de gezondheldszorg en de sociale wetgeving

Te denken valt hierbij zowel aan de structuur van de gezondheidszorg als aan de sociale wetgeving (verg. Soeters, 1983a en b; Tordoir e.a., 1978).

Bif Interventies zal in dit geval vooral de aandacht gericht worden op het verzulmverlengende effect van de structuur van de gezondheidszorg, zoals deze o.a. tot uitdrukking komt in de wachttijd en in het aanbod aan gezondheidszorgvoorzieningen.

Soeters ( $1983 a$ en b) komt ten aanzien van dit aspect tot een aantal aanbevellingen:

- de ultbreiding van specifleke gezondheidszorgvoorzieningen, om het antal wachtdagen te beperken,

- het terugdringen van het aantal verwijzingen,

- een meer systematische informatie-overdracht van de behandelend arts naar de verzekeringsgeneeskundige,

- een verbeterde interactie tussen de verzekeringsgeneeskundige en de patient moet lelden tot een vermindering van de stuurloze periodè.

De keuze voor een benaderingswijze, die gebaseerd is op een van 
de drie bovenstaande aspecten heeft directe repercussies op de aard en inhoud van de interventies.

In dit hoofdstuk zijn de soclaal-gezondheldkundige bastsprinclpes aangegeven, met name de bedreigende en begunstigende factoren en verschillende vormen van interventies. Duldelijk zal zijn dat de oorzaken en vermindering van ziekteverzuim op vele gebleden gezocht kan worden. In hoofdstuk 2 wordt geanalyseerd in welke mate organisatiekenmerken een bijdrage leveren aan de verklaring van verschillen in verzuim tussen organisaties.

Organisatiekenmerken kunnen echter op verschillende manieren gemeten worden, zowel middels objectleve analyses, als door interviews met groepen of individuen werkzaam in die organisatie. De keuze van de aard van de meting zou van invloed kunnen zijn op de effectiviteit van de interventie. Indien gekozen wordt, voor het interviewen van verschillende groepen of individuen in een arbeidsorganisatie, kunnen mogelifk verschillende oordelen over specifieke organisatieaspecten verkregen worden. Dat probleem van verschillen in beoordeling zal centraal staan in de volgende hoofdstukken.

Alvorens over te gaan tot een beschrijuing van de gevonden resultaten, zal in hoofdstuk 2 ingegaan worden op het onderzoek naar de relatie tussen organisatiekenmerken en verschillende arbeidsongeschiktheidsindicatoren, zoals dit ten grondslag heeft gelegen aan het hier besproken onderzoek.

In hoofdstuk 3 zal nader ingegaan worden op de theoretische oorzaken van discrepantie ten aanzien van organisatiekenmerken en op de analyse van deze discrepantle. In hoofdstuk 4 zullen de variabelen beschreven worden die in de volgende hoofdstukken geanalyseerd gaan worden en zullen -op basis van de in hoofdstuk 3 beschreven oorzaken voor discrepantie en de in hoofdstuk 4 beschreven variabelen- de te onderzoeken hypotheses geformuleerd worden. 
$-24-$ 
HOOFDSTUK 2. ORGANISATIEKENMERKEN EN ZIEKTEVERZUIM

\subsection{Inle1ding}

Zoals uit hoofdstuk 1 duidelijk is geworden vormt ziekteverzuim een probleem op zowel micro-, meso-, als macro niveau, dat w11 zeggen respectievelijk op dat van het individu, de organlsatie en de maatschappij. In het kader van deze studie zal de aandacht in eerste instantie gericht worden op de samenhang tussen verzulmen organisatiekenmerken; een samenhang die uitelndelifk zal moeten resulteren in verzulmbeperkende interventies. Verzuimbeperkende interventies op organisatieniveau zullen eveneens hun weerslag hebben op individueel en op matschappelijk niveau. Zo kan bijvoorbeeld door op bedrijfsniveau de arbeldsomstandigheden te verbeteren, de verzuimfrequentie en -duur worden teruggebracht, hetgeen tevens een vermindering van de matschappelijke kosten $\mathrm{van}$ verzuim teweeg $\mathrm{kan}$ brengen. Omdat afwezigheid wegens ziekte op individueel niveau 'zlekte' is, impliceert een genoemde verbetering $v$ an arbeidsomstandigheden eveneens een vermindering $v$ an de individuele gezondheidsproblematiek.

Een goed uitgevoerde diagnose-fase is dus van elementair belang voor het welslagen van een interventie (verg. Rouwenhorst, 1981; Bagchus, 1982 en 'Werk en Ziekte' (Nijhuis en Soeters, 1982) In dat rapport $z i j n$ de relaties weergegeven tussen de betreffende organisatiekenmerken en de drie arbeidsongeschiktheidsindicatoren (verzuimfrequentie, verzuimduur en WAO/IP-toetreding). De methodische aspecten van dat onderzoek zijn beschreven in 2.2 . Van de belangrijkste onderzoeksbevindingen zullen wij in 2.3. een verslag doen. In 2.4 . zullen wij de probleemsteliling uitwerken die, met het hier beschreven onderzoek als basis, de kern vormt van deze studie.

Opzet van het onderzoek

2.2.1. Het aantal deelnemende organisaties

Van de gegevens $v$ an het onderzoek naar de relatie tussen organ1satiekenmerken en ziekteverzuim (N1jhuis en Soeters, 1982) zullen slechts die gegevens vermeld worden die in het kader van dit onderzoek naar discrepantie tussen beoordelaars van belang zifn (voor een uitvoeriger beschrijving, zie Nijhuis en Soeters, 1982 , 
hoofdstuk 3).

Ten behoeve van dat ziekteverzuimonderzoek is een steekproef getrokken ult organisaties, die voldeden aan de volgende criteria:

- vest Iging ultsluitend in Zuld-Limburg, en

- een minimale bezetting van rond de 50 werknemers/sters.

Geen selectle is gemaakt naar de aard van de bedrijvigheld (industrie, overheid, dienstverlening).

De betrokken organisaties verbonden zich om deel te nemen aan:

- het organisatieonderzoek, bestaande ult interviews met zowe1 het hoofd van de productieafdeling, als met het hoofd van de afdeling personeelszaken en met een afvaardiging van de personeelsvertegenwoordiging,

- het patiẻntenonderzoek bij langdurig zieke werknemers (zie Soeters, 1983a),

- de werknemersenquête.

Het verzoek om deelname aan het onderzoek moest positief worden beantwoord door zowel het management als de personeelsvertegenwoordiging. In totaal zijn er 99 organisaties schriftelijk benaderd, waarvan 56 ut de industriële setting en 43 uit de niet-industriële setting. Van de industrlële organisatie heeft $47 \%$ $(\mathrm{N}=26)$ aan het onderzoek deelgenomen. Van de niet-industriële groep bedroeg het deelnemingspercentage $58 \%(\mathrm{~N}=25)$. De gemiddelde positieve respons van $52 \%(\mathrm{~N}=51)$ is niet hoog. Dit kan onder andere verkl aard worden door:

- het grote tijdsbeslag dat deze drie onderzoeken op de organisatie leggen; vooral voor de klelnere organisaties,

- de vrees voor het schaden van de privacy van langdurig zieke werknemers,

- de door ons gestelde dubbele instemmings-els en

- het beperkte directe belang van de organisaties bij de studie.

Voor het hier te beschrijven discrepantieonderzoek werden uit deze 51 bedrijuen die bedrijven geselecteerd, die konden voldoen aan de twee volgende eisen:

- de aanwezigheld van een personeelsvertegenwoordiging,

- de aanwezigheid van direct-uitvoerend mannelijk personee1; hieronder valt het mannelijk personeel dat met $z 1 j n$ werkzaamheden rechtstreeks bif de productie betrokken is. Afwijkend van wat de naam suggereert zijn personeelsleden, werkzasm in storings- of onderhoudsdlensten in het algemeen eveneens als direct-uitvoerend beschouwd.

Deze laatste eis is gesteld, ondat de discrepantie-analyses uit- 
sluitend gedaan zullen worden voor deze, kwantitatief grootste en meest eenduidige, personeelscategorie.

Deze selectie leverde 43 arbeldsorganisaties op, die aan de gestelde elsen voor het discrepantie-onderzoek konden voldoen.

2.2.2. Enkele statististische kenmerken van de onderzochte organisaties

De complexe en uitgebreide opzet van dit project heeft waarschijnlijk geleid tot een lets lager deelnemingspercentage dan gebruikelijk is bij dit type ziekteverzuimonderzoek. Overigens ligt het niet hoge response-percentage in de $11 \mathrm{jn}$ van de algemene tendens tot daling van response bij sociaal-wetenschappelijk onderzoek. Het aantal deelnemende organisaties bereikt echter ruimschoots het oorspronkelijk gestelde doel van 45 deelnemende organisaties.

Tot zover het totalbeeld van de arbeidsorganisaties, die aan dit onderzoek deelnemen. On een eerste indruk te krijgen van het type organisatie, waarover gegevens $z i j n$ verzameld, is een opsplitsing van deelnemende, $c . q$. weigerende organisaties naar sector van be1 ang. Bovendien is aangegeven over welk deel van de organisatles dit discrepantie-onderzoek heeft plaatsgevonden. Tabel 2.1 . bevat deze informatie. 
Tabel 2.1. Deelneming en ultval per sector.

\begin{tabular}{|c|c|c|c|c|c|}
\hline Extor & deondrat & $\begin{array}{l}\text { wedgerng } \\
\text { con non- } \\
\text { dectighe }\end{array}$ & $\begin{array}{l}\text { andere } \\
\text { uitral } \\
\text { (siluting } \\
\text { bedrijf. } \\
\text { e.d.) }\end{array}$ & 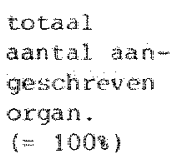 & $\begin{array}{l}\text { aantal } \\
\text { organisaties } \\
\text { in de dis- } \\
\text { crepamtia } \\
\text { ancilyse }\end{array}$ \\
\hline 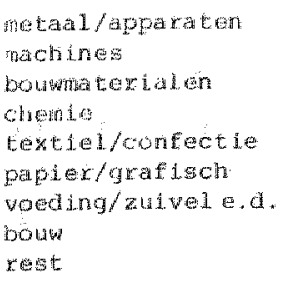 & $\begin{array}{ll}9 & (56 \%) \\
5 & (100 \%) \\
3 & (38 \%) \\
2 & 33 \% \\
2 & (40 \%) \\
1 & (17 \%) \\
4 & (50 \%) \\
- & \end{array}$ & $\begin{array}{ll}7 & (440) \\
- & \\
4 & (504) \\
3 & (50 \%) \\
3 & (608) \\
4 & (670) \\
4 & (50 \%) \\
2 & (100 \%)\end{array}$ & 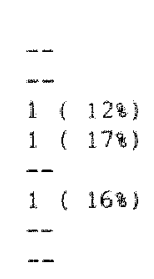 & $\begin{array}{r}16 \\
5 \\
8 \\
6 \\
5 \\
6 \\
8 \\
2\end{array}$ & $\begin{array}{l}7 \\
5 \\
4 \\
2 \\
1 \\
1 \\
3 \\
-\end{array}$ \\
\hline Lndusdre & $26(476)$ & $27(48 \%)$ & $3(58)$ & 56 & 23 \\
\hline 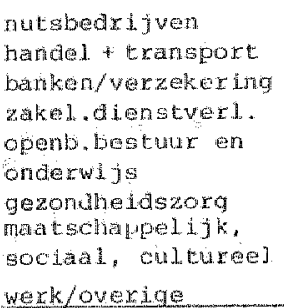 & $\begin{array}{l}6(100 \%) \\
3(25) \\
3(60 \%) \\
4(504) \\
6(100) \\
3 \times 50 \%)\end{array}$ & $\begin{array}{l}9(75) \\
2(408) \\
4(509) \\
3(509)\end{array}$ & $\begin{array}{c}-- \\
-- \\
-\cdots \\
-\infty \\
-\infty \\
--\end{array}$ & $\begin{array}{r}6 \\
12 \\
5 \\
8 \\
6 \\
6\end{array}$ & $\begin{array}{l}5 \\
1 \\
2 \\
4 \\
6 \\
1\end{array}$ \\
\hline $\begin{array}{l}\text { niet-incustriele } \\
\text { organisaties }\end{array}$ & $25(584)$ & $18(428)$ & -- & 43 & 19 \\
\hline totaral & $514521)$ & $45 \quad(458)$ & $3(38)$ & 99 & 42 \\
\hline
\end{tabular}

Bij deze tabel zijn de volgende opmerkingen te maken ten aanzien van de gehele steekproef:

- De reden van uitval, die het meest voorkomt is de welgering van of namens de directie. Deze reden is hier niet verder uitgesplltst; meestal gaat het om verwijzingen naar te drukke werkzaamheden in de organisatie, personeelsgebrek en in sommige gevallen om verwijzingen naar op handen zijnde reorganisaties en/of naar soortgelifk reeds eerder in de organisatie verricht onderzoek. De uitval vanwege non-decisie, na meerdere pogingen van onze kant on een uftspraak te krijgen, is in de meeste gevallen onder de noemer 'weigering directie' te scharen.

- In drie gevallen is de weigering expliciet afkomstig van de personeelsvertegenwoordiging; twee keer gebeurde dit in verband met de privacy-problematiek ten aanzien van het doorgeven van 
namen van zleke personeelsleden.

- Uit de opsplitsing naar sector blijkt dat van de grotere sectoren alleen de voedingsbranche en de handel ondervertegenwoordigd zijn. De steekproef van deelnemende organisaties vertoont enkele duidelijke clusters, bijvoorbeeld de metaalindustrie, de bouwmaterialenindustrie, de nutsbedrijven en de gezondheidszorg. In deze sectoren is in het algemeen coôperatief gereageerd op de uitnodiging tot deelname aan het project.

Tot slot van deze globale steekproefbeschrijving volgt in tabel 2.2. een overzicht van de omvang van de aan het ziekteverzuimonderzoek deelnemende organisaties.

Tabel 2.2. Personeelsomvang van de deelnemende organisaties.

\begin{tabular}{|lcc|}
\hline Personeelsomvang & $\begin{array}{c}\text { aantal } \\
\text { organisaties }\end{array}$ & $\begin{array}{l}\text { percentage van het } \\
\text { totaal aantal deel- } \\
\text { nemende organisaties }\end{array}$ \\
\hline minder dan 100 werknemers & 14 & $27 \%$ \\
$100-200$ werknemers & 17 & $33 \%$ \\
$200-500$ werknemers & 12 & $24 \%$ \\
meer dan 500 werknemers & 8 & $16 \%$ \\
\hline totaal & 51 & $100 \%$ \\
\hline
\end{tabular}

Bij het industriële gedeelte van onze steekproef hebben we nog de non-respons naar organisatie-omvang kunnen nagaan.

Hieruit bleek, dat de uitval groter was, naarmate het om kleinere organisaties ging. Dit is goed te begrijpen, gegeven de veel genoemde reden tot weigering: $t i j d s-$ en personeelsgebrek. Vanwege het schaalvoordeel zal dit bezwaar zich bij grotere organisaties mogelijk in mindere mate voordoen.

Wellicht ten overvloede $z i j$ nog vermeld, dat voor ledere ultgevallen organisatie een reserve uit dezelfde sector- en omvangscategorle werd aangeschreven.

Ten aanzien van de organisaties die in de discrepantie-analyse zullen worden meegenomen kunnen wij constateren dat de ultval van arbeidsorganisaties uit de niet-industriële sector groter 18 . Enerzijds wordt dit veroorzaakt door de afwezlgheid van directproductiepersoneel en anderz1jds doordat deze organisaties vaak 
kleiner zijn, waardoor een personeelsvertegenwoordiging ontbreekt.

Bovendien valt een aantal kleinere arbeidsorganisaties uit de analyse weg. Door het ontbreken van een personeelsvertegenwoordiging, in klelnere arbeldsorganisaties, wordt de hier te verrichten discrepantle-analyse namelijk onmogelijk. De personeelsomvang van de in de discrepantie-analyse betrokken organisaties 1 s vermeld in tabel 2.3 .

Tabel 2.3. Onvang van de bij de discrepantie-analyse betrokken organisaties.

\begin{tabular}{|lcc|}
\hline Personeel somvang & $\begin{array}{c}\text { aantal } \\
\text { organisaties }\end{array}$ & $\begin{array}{l}\text { percentage van het } \\
\text { totaal aantal deel- } \\
\text { nemende organisaties }\end{array}$ \\
\hline $\begin{array}{l}\text { minder dan } 100 \text { werknemers } \\
100-200 \text { werknemers }\end{array}$ & 15 & $17 \%$ \\
$200-500$ werknemers & 12 & $35 \%$ \\
meer dan 500 werknemers & 8 & $29 \%$ \\
totaal & 42 & $19 \%$ \\
\hline
\end{tabular}

2.2.3. De representatitiveit van de deelnemende organisaties

Bij een organisatieonderzoek als het onderhavige is het moellijk om grote antallen in de steekproef op te nemen; dit zowel vanwege de hoge non-respons als vanwege het tijdsbeslag en de financlële voorwaarden voor een dergelijk onderzoek. Een dergelljke beperking doet de vraag rijzen naar de representativiteit van de bevindingen.

Naast het feit dat geanalyseerd zal worden of, en ten aanzien van welke organisatiekenmerken, systematische verschillen tussen beoordelaars bestaan, is tevens het doel om verbanden aan te geven tussen discrepanties tussen beoordelaars enerzijds en verzuim- en organisatiekenmerken anderzijds is een statistische representatieve steekproef uit het bekende universum niet noodzakel1jk 1s (vergelijk: Philipsen, 1969a en b). Het gaat er namelifk niet om hoe groot de gevonden verschillen tussen beoordelaars in Zuld-Limburg zijn, maar om vast te stellen welke organisatieaspecten een samenhang vertonen met een hogere of 
lagere discrepantie.

Dat wij onze steekproef beperkt hebben tot Zuid-Limburg doet evenmin afbreuk aan de generaliseerbaarheid van de conclusies, omdat er geen reden is om aan te nemen dat de organisatiekemerken en de te vinden verschillen tussen beoordelaars in Zuid-Limburg afwijkend is $v$ an dezelfde aspecten in de rest van Nederland.

2.2.4. De verschillende beoordelaars

Zoals eerder gesteld zijn er interviews geweest met:

a) het hoofd van de productie of dienstverlening, hier verder management genoemd (indien niet lemand met een dergelifke positie gevonden kon worden werd de chef van de belangrijkste afdeling(en) geinterviewd);

b) de voor het personeelsbeleid verantwoordelijke functionaris;

c) een aantal leden van de functionerende personeelsvertegenwoordiging, meestal de ondernemingsraad.

De functies van de respondenten zijn vermeld in tabel 2.4 .

Deze verschillende categorieën respondenten zullen in deze dissertatie beoordelaars genoemd worden.

Tabe1 2.4. Functies $v$ an de respondenten.

\begin{tabular}{|c|c|c|}
\hline$\longdiv { \text { Categorie } }$ & Functile & Aantal \\
\hline Management & $\begin{array}{l}\text { hoofd van de productie of dienst- } \\
\text { verlening } \\
\text { chef van de belangrijkste } \\
\text { afdeling } \\
\text { directeur of een directie-/ } \\
\text { bestuurslid } \\
\text { anders }\end{array}$ & $\begin{array}{r}19 \\
9 \\
12 \\
2\end{array}$ \\
\hline Personeelszaken & $\begin{array}{l}\text { hoofd/directeur personeelszaken } \\
\text { algemeen directeur/directielid } \\
\text { algemeen personeelschef } \\
\text { anders (coordinator, bedrijfslei- } \\
\text { der, chef salarisadministratie) }\end{array}$ & $\begin{array}{r}11 \\
19 \\
8 \\
4\end{array}$ \\
\hline $\begin{array}{l}\text { Personeelsver- } \\
\text { tegenwoordiging }\end{array}$ & $\begin{array}{l}\text { ondernemingsraad } \\
\text { georganiseerd overleg } \\
\text { andere vormen (bureauraad, mede- } \\
\text { zeggenschapscommissle) }\end{array}$ & $\begin{array}{r}31 \\
6 \\
5\end{array}$ \\
\hline
\end{tabular}


Deze drie interviews bestonden uit gestructureerde vragenlijsten. Wij namen elk maximaal een halve dag in beslag. Deze gesprekken zijn ter plaatse gevoerd bij alle organisaties door een drietal verschillende veldonderzoekers. Per groep respondenten is gebrulk getiakt van twee verschillende interviewers. Dit komt de unfformitelt van de ciffertoekenningen ten goede. Voor en tijdens het veldwerk heeft regelmatig overleg plaats gevonden over de interpretatie van diverse vragen; hierbij werd $0 . a$. afgesproken dat bij scorlngsproblemen een precieze onschrijving gegeven zou worden van de speclfleke bedrijfssituatle. Hierna is de codering in handen gegeven wan Eén onderzoeker, dle op basis van het gezamen$11 j k$ ontwlkkeld codeersysteem de ontbrekende cijfertoekenningen heeft aangevuld. Op deze wijze is geprobeerd on de onderlinge consistentie van de scores te optimaliseren.

De beoordeling van de organisatiekenmerken door werknemers heeft geen onderdeel ultgemaakt van dit onderzoek. Wel zal ten aanzien $v$ an de beoordelingen van de arbeidsomstandigheden een gemiddelde werknemersscore gecreëerd worden op basis van de werknemersenquête (zie: 2.2 .1$.$) .$

2.3. Samenvatting van de belangrijkste resultaten van de relaties tussen de zlekteverzulm- en arbeldsongeschiktheidsindicatoren enerzijds en de organisatiekenmerken anderzijds

In deze paragraaf zullen we omwlle van de beknoptheid slechts de belangrijkste significante verbanden ult het onderzoek bespreken (zie: Nijhuls en Soeters, 1983). We beperken ons daarbij tot de in omvang grootste onderzoeksgroep, namel1jk het mannel $1 \mathrm{jk}$ productlepersoneel. We zullen deze verbanden groeperen tot een beperkt aantal hoofdcategorieën. De gegevens zijn geanalyseerd middels twee verschillende technieken, te weten een multiple regressle-analyse en een partielle correlatie-analyse.

voor een total overzicht van analyses en resultaten verwijzen wij naar Nijhuls en Soeters (1982).

Bijlage 2 geeft de correlatles na partialisatle van de in dit hoofdstuk besproken relatles tussen organisatiekenmerken en de verzuimfrequentie, de verzuimduur en het antal WAO/IP-toetredingen. De belangrijkste bevindingen van Nijhuis en Soeters ( 1982 en 1983) worden hier weergegeven, omdat bif interventies, gebaseerd op deze verbanden, rekenling gehouden dient te worden met mogelifke verschillen tussen categorleën beoordelaars. 
2.3.1. Invloed van bezwarende werkomstandigheden

Hinderlijke en bezwarende werkomstandigheden zijn te verdelen in een tweetal groepen, te weten de meer fysiek bezwarende werkomstandigheden (geluid, trilling, tocht, temperatuur, e.d.) en de meer psychische belastende werkomstandigheden (eentonigheid, werksfeer, rolonduidelijkheid, e.d.). Gevraagd is aan de respondenten in welke mate het uitwoerend personeel hinder ondervond van deze werkomstandigheden.

2.3.1.1. Invloed van fysiek bezwarende werkomstandigheden

over de relatie tussen fysiek bezwarende werkomstandigheden en ziekteverzuim is reeds veel bekend (Philipsen, 1969a; RIs, 1978; De Jong e.a., 1981).

Ook ult Nijhuis en Soeters (1982) blijkt dat meer fysiek bezwarende werkomstandigheden samenhangen met een verhoogde verzulmfrequentie, een langere ziekteduur en een groter aantal WAO/IPtoetredingen. Voorts blijkt dat een door de organisatie intensief gevoerd beleid gericht op verbetering van arbeidsomstandigheden samenhangt met een hogere frequentle, een langere ziekteduur en een hogere WAO-instroom. Dit moet verklaard worden uit het feit dat beleid vooral daar gericht is op verbetering van arbeidsomstandigheden war slechte arbeldsomstandigheden aanwezig zifn (samenvallend in tijd). Deze verklaring wordt versterkt door de hoge correlatie tussen de mate waarin werknemers hinder ondervinden van slechte arbeidsomstandigheden en het beleid gericht op verbetering van arbeidsomstandigheden $(x=.31 ; p=0.001)$. Bovendien gaat het bij een dergelijke aanpak vaak om projecten van korte duur die de totale verzulmituatie slechts gedeeltelijk beInvloeden. Een uitzondering op deze bevindingen blifkt de relatie tussen de verzuimind 1 atoren en het voorkomen van ploegendienst. Meer intensieve vormen van ploegendienst blijken samen te gaan met een lagere verzuimfrequentie en met een groter aantal WAO/IP-toetredingen. Dit kan verklaard worden vanult het optreden van het 'Healthy worker' effect (zie: Vinni en Hakama, 1980; Olsen, 1981). Door onder andere (zelf) selectie zullen mensen die in meer intensieve vormen $v$ an ploegendlenst werken een relatief gezonde populatle vormen. Indlen een werknemer in ploegendienst echter een aandoening krijgt, die het werken in ploegendienst bemoeflijkt, dan $1 s$ ander werk moellijk te vinden en volgt afvloeling uit het arbeldsproces door middel van de WAO/IP. 
2.3.1.2. Invloed van laag gekwalificeerde arbeid

Psychisch belastende werkomstandigheden vormen, bij het productlepersoneel, vaak een element van laag gekwalificeerde arbeld (eentonlg, welndg uitdagend werk). Vandaar dat dit belastingsaspect, samen met het gemiddelde opleidingsniveau, onder deze categorle geplaatst is. Het verband tussen psychisch belastende werkomstandigheden en een hoger verzuim wordt in de literatuur regelmatig gesignaleerd, maar wordt slechts in beperkte mate door empirisch onderzoek onderbouwd (Van Vucht Tijssen e.a., 1978; De Jong e.a., 1981). Zowel psychisch bezwarende werkomstandigheden (onder andere: werksfeer, eentonigheid, rolonduidelifkheid) als een lager opleidingsniveau blijken samen te hangen met een hogere verzuimfrequentie en een langere verzuimduur. Bovendien gat laag gekwaliflceerde arbeld eveneens gepaard met een groter aantal WAO/IP-toetredingen.

\subsubsection{Invloed van social support}

De mogelijkheid tot social support is in het betreffende onderzoek onder meer gemeten door de mate van hlërarchisering van de organisatiestructur en door de mate warin werkoverleg binnen de organisatle gestalte heeft gekregen. In een meer hiërarchisch opgebouwde, milnder platte organisatiestructuur zijn de werkgroepen kleiner; enerzijds leidt dit tot betere mogelijkheden tot het onderhouden van sociale contacten en is er een grotere kans op meer bevredigende relaties tussen chef en ondergeschikte, anderzljds wordt door een minder platte organisatiestructur verhinderd dat een individuele baas te zeer zijn stempel drukt op een grote groep personeelsleden.

De resultaten van dat onderzoek wijzen ult dat in plattere organisaties, met relatlef grotere werkgroepen, de verzuimfrequentie en verzulmduur hoger 11 ggen. Tussen verzulm en werkoverleg is, in ander zlekteverzuimonderzoek, slechts in beperkte mate een relatie gevonden (RIs, 1978; Koopman-Iwema, 1982). Smulders (1980) wijst erop dat in de meerderheld der gevallen werkoverleg samengat met een verminderd verzuim.

Een meer gestructureerd werkoverleg blijkt, volgens de bevindingen in dle studie, niet zozeer de verzuimfrequentle te belnvioeden, maar vooral samen te hangen met een kortere verzuimduur en met een geringer aantal WAO/IP-toetredingen. Dit kan verklaard worden doordat werkoverleg drempelverlagend werkt ten aanzien van de terugkeer naar de werkplek. Werkoverleg biedt bijvoorbeeld de 
mogelijkheid om bij de werkverdeling rekening te houden met ziekte en handicap.

2.3.3. Invloed van de economische situatie van de organisatie

Een gangbare hypothese is dat bij stijging van werkloosheld een daling optreedt van het verzuim (Behrend, 1953; Crowther, 1957; Plummer en Hinkle, 1955; Steers en Rhodes, 1978; Enterline, 1964 en 1966). Deze daling kan zowel ontstaan door vrees voor werkloosheid, als door een selectleve uitstoot van personeelsleden waardoor de werknemerspopulatie 'gezonder' is geworden. In de literatuur worden geen eenduidige verbanden gevonden, al is er een tendens te constateren dat bij verminderde werkzekerheid de verzuimfrequentie afneemt (Dijkstra, 1974; Buringh, 1977a en b; Tay1or en Pocock, 1969; Smulders e.a., 1983; Smulders, 1983).

Recentelijk is door Kruldenier (1981 en 1983) vastgesteld dat de daling $v$ an het verzuim zowel veroorzaakt wordt door de afname van zowel de verzuimfrequentie als van het langer durend verzuim. De daling $v$ an het verzuimpercentage komt vooral tot stand door een daling in het aantal verzuimgevallen, die langer duren dan zes weken. In overeenstemming hiermee bleek dat een geringere mate van werkzekerheid samenhangt met zowel een geringere verzuimfrequentie als een kortere verzuimduur. Een bedreiging $v$ an de werkgelegenheid lijkt derhalve te leiden tot een verhoging van de drempel tot zlekmelding en een snellere herstelmelding. Kruidenier (1983) verklaart dit effect door te wijzen op een geringere werkbelasting enerzijds en een verscherpte selectle op gezondheid bij het aantrekken van werknemers anderzijds. Vooral in bedrijven waar het economisch beter gat neemt de verzuimdur af, hetgeen een gevolg kan zijn van een 'harder' personeelsbeleid en een verdergaande intensivering $v$ an de arbeld (Nijhuis, 1983). Deze intensivering van de arbeid blijkt onder andere ult het felt dat in organisaties, met goede werkgelegenheidsvoorultzichten, de productiedruk groter is, evenals de onmisbaarheid van werknemers. Voorts blijkt dat veel veranderingen in taken gepaard gaan met een daling in de verzuimfrequentie en -duur. DHt wettigt de veronderstelling dat veel investeringen lelden tot verbeteringen in de arbeldssituatie. Dok arbeldsorganisaties zullen in een situatie van laagconjunctuur hun rendement verbeteren, hetgeen resulteert in veranderingen, die minder snel leiden tot zlekte en arbeidsongeschiktheid. 
2.3.4. Invloed van personeelsbeleid

De invloed $v$ an het personeelsbeleid is onder meer gemeten via de grootte van de afdeling personeelszaken en het gemiddelde opleidingsniveau $v a n$ de personeelsfunctionarissen, alsmede via een aantal aspecten van personeelsbeleld (bijvoorbeeld beleid gericht op het aanpassen $v$ an taken en functles aan handicaps van werknemers, opleidings- en beoordelingsbeleid).

De beperkende 1nvloed wan een meer professloneel gestructureerde personeelsafdeling op de verzuimdur is reeds vaker geconstateerd (Philipsen, 1969a; Ris, 1978). In de literatuur wordt echter geen melding gemaakt van een relatie tussen enerzijds professionalisering van een afdeling personeelszaken als zodanig en anderzijds de verzulmfrequentle en de WAO-toetredingen. Ten aanzien van de verschillende vormen van personeelsbeleid zijn slechts beperkte en dan nog niet eenduldige gegevens in de literatuur aanwezig (R1s, 1978; De Jong e.a., 1981).

Uit $\mathrm{N}$ jhuis en Soeters (1983) blijkt dat professionalisering van de afdeling personeelszaken verzuim- en/of arbeldsongeschiktheids-beperkende effecten sorteert.

Voorts blijkt een beleid gericht op het creëren van meer moge11jkheden voor werk in aangepaste functies samen te hangen met een lagere verzuimfrequentle en een hogere verzuimduur.

Dit laatste fenomeen kan verklaard worden vanut de aanname dat bij organtsaties met een gemiddeld langere verzuimdur eerder aandacht besteed zal worden aan meer gerlchte anpassingsactiviteiten. Dit geldt echter nog niet voor andere onderzochte vormen van personeelsbeleld. Een meer systematisch beleld, gericht op beloning en beoordeling of op omschollng $11 j \mathrm{kt}$ namelijk samen te hangen met een hogere verzuimfrequentie (promotiestress) (verg.: Vreeman, 1982).

\subsubsection{Invloed van de factor personeelsbezetting}

De mate warin een organisatle blinnen het arbeldsproces hinder ondervindt $v$ an afwezigheid wegens ziekte is zeer verschillend. Het betreft daarblj nlet alleen gevolgen voor de productie, maar ook voor de overblijvende collega-werknemers. Af we zlgheid wegens zlekte kan onder andere lelden tot herverdeling van werkzamheden, tot tljdelijk extra overwerk of tot verlenging van de levert1jden. Het geheel van dergellfke ad-hoc wijzigingen, veroorzaakt door zlekte van werknemers wordt verstoring van het arbeldsproces genoemd. Vooral van belang was daarbif in welke mate deze ver- 
storing drukt op de overige werknemers. Deze druk is afhankelijk $v$ an de bezettingsgraad $v$ an de organisatie. Indien de bezettingsgraad an de lage kant is, zal afwezigheid ten gevolge van ziekte leiden tot een sterke verstoring van het productieproces, hetgeen gepaard zal gaan met een extra werkbelasting (Vreeman, 1982). Bestaande literatuur duldt erop dat een hoge mate van verstoring In het arbeldsproces samen gaat met een daling $v$ an de verzulimfrequentle (Ris, 1978) en een structureel personeelstekort met toename van de kans op langdurige ziekte en WAO-toetreding (De Jong e.a., 1981).

Dit beeld wordt door de resultaten uit dit onderzoek bevestigd. Naarmate de verstoring van het arbeldsproces groter en de personeelsbezetting krapper is, is de verzuimfrequentie geringer, maar de verzuimduur juist langer en het aantal WAO/IP-toetredingen groter. Door verkleining van de personeelsbezetting kan de verzuimdrempel verhoogd worden, ondat zlekmelding sneller directe repercussies heeft voor de collega-werknemers. De drempel om terug te komen wordt daarmee eveneens verhoogd, omdat de elsen die aan de werknemers gesteld worden zwaarder zijn. De lagere frequentie en de langere duur van het zlekteverzulm $11 \mathrm{jkt}$ daarmee eveneens een effect te $z 1 j n$ van een verdergaande intensivering $v$ an de arbeld en een krapper wordend personeelsbestand. Behalve door een verkleining $v$ an de personeelsbezetting blijkt de bedrijfseconomische optimalisering van de personeelsbezetting door de arbeldorganisaties ook nog via andere sporen bewerkstelilgd te worden, zoals door middel van vervroegde pensionering en verhoogde afvloeilng middels de WAO/IP. Het veelvuldig voorkomen van vervroegde penstonering gaat dan ook samen met een stijging van de verschillende verzulm- en arbeldsongeschiktheidsindicatoren.

2.3.6. Invloed van verschillen in arbeidsoriëntatle

In overeenstemming met Philipsen (1969a) blijkt dat arbeidsorganisaties, die hun werknemers meer uit sterker geurbaniseerde gebieden betrekken, gekenmerkt worden door een verhoging van de verzuimfrequentie, een verlenging van de verzulmduur en een groter aantal WAO/IP-toetredingen. Een soortgelljk effect zien we bij de relatie tussen verzuim en leeftijd. De verzuimfrequentie is hoger, naarmate de leeftijd van het personeel gemiddeld lager 1s. Dok hier lijkt een verschil in arbeldsoriëntatie verantwoordelijk voor dit effect. De samenhang tussen verstedelifking en het aantal WAO/IP-toetredingen kan mede verklaard worden door de samenhang met de reglonale arbeldsmarkt. Door de grotere geregis- 
treerde arbeldsreserve in de meer verstedelijkte gebieden in Zuid-Limburg kan bij de toekenning van WAO-uitkeringen de arbeidsmarktindicatie vaker gehanteerd worden (art, 21-2la) (z1e: Sieger 8,1981$)$.

2.3.7. Invloed van de grootte van de arbeldsorganisatle

De organisatie-omvang, in termen van het aantal personeelsleden, blifkt in eerdere studies wamen te hangen met een kortere verzuimduur (Philipsen, 1969a). Dit kan verklaard worden, doordat grotere organisaties in staat $z 1 j n$ een meer professionele personeelsbegelelding te ontwikkelen. Deze bevinding blijkt enige nuancering. Zo blijkt een grotere organisatieomvang namelijk samen te hangen met een lagere verzuimfrequentie en met een groter aantal WAO/IP-toetredingen. Een meer professionele personeelsbegeleiding kan ertoe lelden dat verzuimbevorderende factoren worden opgeheven (lagere frequentle), maar ook dat 'de weg naar de WAO/IP' (de arbeidsongeschiktheidswetgeving) beter bekend is.

2.4. Probleemste111ng

In een groot aantal onderzoeken naar de oorzaken van ziekteverzuim in arbeldsorganisaties worden uitspraken gedaan over samenhangen tussen organisatiekenmerken en verschillende ziekteverzuimindicatoren.

De anwezigheld van kennis en inzicht betreffende de relatie tussen ziekteverzuim/arbeidsongeschiktheid enerzijds en organisatiekenmerken anderzijds betekent echter nog niet dat daarmee ook de 'oplossing' voor de zlekteverzuimproblematiek in de organisatle gegeven is. Het vinden van samenhangen tussen organisatiekenmerken betekent echter nog niet dat daarmee ook de vorm van de interventie gevonden is. Geconstateerde samenhangen geven namelijk slechts correlationele verbanden aan en geen causale. Zo is een positieve samenhang geconstateerd tussen drie verschillende arbeldsongeschikt heidsind ic atoren (verzuimfrequentie, verzulmduur en aantal WAO/IP-toetredingen) en de mate waarin door het bedriff een meer systematisch beleid gevoerd wordt ten aanzien van de verbetering van de arbeidsomstandigheden (Nijhuls en Soeters, 1982). Dit gegeven $11 \mathrm{jkt}$ echter verklaard te moeten worden door een relatie tussen de aard van de arbeidsomstandigheden en verbeteringen van die arbeidsomstandigheden. Bovendien behoeft informatie over de samenhang tussen organisatiekenmerken 
en arbeidsongeschiktheldsindicatoren niet onmiddellijk inzicht te geven over de noodzakel1jke vorm van interventie, ondat de informatie over de betreffende organisatiekenmerken veelal gekleurd is en er in de organisatie een soclaal-psychologisch klimat is gegroeld, dat de effectivitelt van interventle belnvloedt. We zullen dit verduldelijken aan de hand $v$ an enkele voorbeelden. Dat slechte arbeidsomstandigheden verzulmbevorderend $z i j n$ mag als algemeen bekend worden verondersteld; onduidelijk is vaak in een bedrijf welke arbeldsomstandigheden daar het meest aan bijdragen. Zo bleek tijdens een cursus voor kaderleden van een slachterij -met een breed scala van slechte arbeldsomstandigheden (1 awaal, vettigheid, eentonige arbeid gericht op prestatiebeloning, tocht, vocht, water)- dat door de werknemers alle klachten geminimaliseerd werden met uitzondering van een tweetal: het bijna permanent werken met de voeten in het water en de tocht door de openstaande deuren, waarvoor regelmatig vrachtwagens met lopende motoren (ten behoeve van de koellng) staan (uitlaatgassen). Deze beide laatste problemen schoven de andere klachten naar de achtergrond. Waarschijnlijk zullen in een dergelijk geval interventies gericht op lawalbestrijding en op vermindering van de directe koppeling tussen prestatie en beloning weinig effect sorteren. In een ander bedrijf bestond al sinds geruime tijd een (volgens de bedrijfsleiding ten onrechte) vrees voor reorganisaties en gedwongen ontslagen. Interventies in een dergelifk bedrijf zullen veelal -terecht of ten onrechte- gepercipieerd worden als eerste stappen van een reorganisatieplan en derhalve lijkt de kans groot dat dergelljke interventies op een breed verzet zullen blijken te stuiten.

Bovendien kunnen verschilien in perceptle van de kenmerken van de arbeldssituatie de aard van de interventie belnvloeden. Deze perceptie kan afhangen $v$ an de plaats $v$ an de informant in de organisatie. B1j een niet goed werkend beoordelingssysteem is het niet ondenkbaar dat personeelszaken de beschuldigende vinger uitsteekt naar de chefs (die niet bij machte zijn het personeel te beoordelen) en de chefs zullen op hun beurt weer een beschuldigende vinger ultsteken naar de afdeling personeelszaken, die hen van te weinig vaardigheld en steun voorziet. De noodzaak van een dergelijke diagnose van de arbeldsorganisatie, voordat tot interventie kan worden overgegaan 18 dan ook een open deur (Bagchus e.a., 1982; Smulders, 1982; Von Rosenstiel e.a., 1975; March en Simon, 1958; Koot, 1980).

Minder eenduidig echter $21 j n$ verschillende auteurs over de inhoud en ard van een organisatie-diagnostiek in deze. Onvoldoende ge- 
toetste opvattingen over aard en inhoud van het probleem richten maar al te veel de interventles; dit met het risico dat het proces van verandering in een verkeerde richting wordt geleid, symptomen worden bestreden, deeloplossingen worden gekozen en tegenwerking verkeerd wordt ingeschat. Een diagnose zal ook moeten aangeven in welke mate organisatiekenmerken aan elkaar gerelateerd zijn en elkaar belnvloeden, waarin opvattingen over het effect $v a n$ diverse organisatiekenmerken kunnen verschillen, hoe groot de veranderbaarheld is van specifleke organisatiekenmerken en de functie van kenmerken en gedragingen van in de organisatle functlonerende individuen (vergelijk March en Simon, 1958).

Opvallend $1 \mathrm{~s}$ dat $b 1 j$ de meting van organisatiekenmerken vaak wordt ultgegaan van enerzijds objectieve, administratief vastliggende, gegevens en anderzijds van gegevens verkregen via interviews met de bedrijfsleiding (personeelschef, bedrijfsleider, directeur) (Philipsen, 1969a; Ris, 1978; Nijhuis en Soeters, 1982). Dat b1j de meting van organisatiekenmerken meestal wordt ultgegaan van objectieve gegevens wekt enige bevreemding, omdat een van de belangrijkste assumptles van onderzoek naar de relatie tussen organisatiekenmerken en ziekteverzuim is, dat de variantie in duur en frequentle van het verzuin mede afhankelijk is van een Individuele weging van belastings- en belastbaarheids factoren en daarmee van de individuele perceptle van de eigen situatie. Een aanname blj dergelijk onderzoek is dat de organisatiekenmerken -zoals deze gemeten worden- een adequate weergave zijn van de werkelijkheid. Dit probleem tussen de 'objectieve realiteit" en de representatie van deze realiteit in de kennis van factoren is al sinds 1 ang een methodisch probleen (De Vries, 1977). De kennis die wif bezitten over de feltelijke impact van de werkorganisatie op de reacties van de werknemers (zoals zlekteverzuim) is gering (Newnan, 1975). Het is dan ook noodzakelifk om de invloed van deze organisatiekenmerken op de beleving en reacties van de werknemex s verder te bestuderen (Dunham, 1977).

Bekend $1 \mathrm{~s}$ wel dat tussen groepen werknemers (witte en blauwe boorden) verschilien bestaan in opvattingen over de maatschappijstructuur en over de hiërarchische structuur binnen organisaties (Popitz, 1957; Goldthorpe e.a., 1969; Laterveer, 1972). Alestalo (1979) laat zien dat naarmate men - In een researchlaboratorlum- op een hogere positie werkzaam is, meer kansen en mogelijkheden voor het lagere personeel om invloed op de besluitvorming ult te oefenen waargenomen worden. Ook in simulatiespelen blijken versch11en in opvattingen te ontstaan tussen Individuen, 
die meer centraal in het betreffende simulatiespel staan, en individuen die een meer perffere rol bekleden (van der Meer en Schreuder-Peters, 1980; van der Meer, 1982).

Dergelijke discrepanties in percepties bestaan eveneens ten aanzien van ongevingsaspecten, zoals luchtwervuiling (Peeters en wan Sprunde 1, 1980).

Naast het bestaan van verschillen in attitude is ook bekend dat er verschillen bestaan tussen de resultaten van verschillende meetmethoden (interview, observatie) ten aanzien van inhoud en opvattingen over specifieke taakkenmerken (hoofdstuk 4).

In de opzet van dit onderzoek (2.2.) leidde de signalering van deze problematiek dan ook in de dataverwerving tot het betrekken van informatie over organisatiekenmerken middels verschillende beoordelaars. Kennis over deze verschillen en overeenkomsten, tussen het oordeel van verschillende groepen in een arbeldsorganisatie, is noodzakelijk om tot de nodige sociaal-gezondheidkundige interventies te komen. Dit thema zal in dit proefschrift centraal staan.

Het vergaren van informatie bij verschillende beoordelaars (management, personeelszaken, personeelsvertegenwoordiglng en werknememers) kan leiden tot mogelijke discrepanties in beoordelingen van verschillende kenmerken $v$ an de arbeidsorganisatie.

Deze discrepantie-thematiek, zal in de onderhavige studie centraal staan en is aanleiding geweest tot de volgende probleemste11ingen:

IA $Z i j n$ er tussen management, personeelszaken, personeelsvertegenwoordiging verschillen in beoordeling ten aanzien van aspecten van de arbeldsorganisatie?

IB $\mathrm{Z} 1 \mathrm{jn}$ deze verschillen systematisch en onderscheiden organisaties zich van elkaar ten aanzien van dergelifke verschillen?

IC In welke mate worden deze systematische verschillen tussen de beoordelingen verklaard door kenmerken van de organisatie?

II In hoeverre kan de onderlinge afwijking ten aanzien van deze specifieke kenmerken verklaard worden door observatoreigenschappen? 
III In welke mate verklaren eventueel te vinden discrepantlematen de verschillende zlektefrequentle en -duurpatronen tussen arbeldsorganisaties?

Alvorens over te gaan tot een beschrijuing van de gevonden resultaten, zal in hoofdstuk 3 nader ingegaan worden op de theoret1sche oorzaken van discrepantie ten aanzien van organisatiekenmerken en op de analyse van deze discrepantie.

In hoofdstuk 4 zullen de variabelen beschreven worden, die in de daarop volgende hoofdstukken geanalyseerd gaan worden. Vervolgens worden de onderzoekshypothesen geformuleerd en wel op basis $v$ an de in hoofdstuk 3 beschreven mogelijke oorzaken voor discrepantie en de $\mathbb{1 n}$ hoofdstuk 4 beschreven variabelen.

Aan de vraagstellingen genoemd onder $I$, II en III $z$ al in de hoofdstukken 5,6 en 7 aandacht worden besteed.

In hoofdstuk 8 worden ten slotte een aantal algemene conclusies gegeven ten aanzien van de implicaties van de onderzoeksbevindingen voor de mogelijkheden tot verzulmbeperkende interventies op organisatieniveau. 
HOOFDSTUK 3. DISCREPANTIE ALS ONDERZOEKSOBJECT

3.1. Inleiding

Arbeidsorganisaties kunnen op zeer uiteenlopende wijzen gekarakteriseerd worden. Bekende typeringen zijn die van organisaties als gesloten of open systemen, als democratische of autoritaire systemen, als bureaucratische of informele systemen, in termen van input en output of van elkaar beinvloedende subsystemen (vergelijk Katz en Kahn, 1978). Een dergelijke veelvuldigheid $1 \mathrm{n}$ typeringen is mede een effect van het grote aantal verschillende processen die binnen een werkorganisatie plats hebben. Door verschillen in de invalshoek waarmee de onderzoeker naar de werkorganisatie kijkt ontstaan verschillende indelingscriteria.

Binnen de werkorganisatie zelf wordt eveneens op zeer veel verschillende manieren tegen de organisatie aangekeken. Zo kan in dezelfde organisatie de vraag of er een personeelsbeoordelingssysteem is bij de dienst personeelszaken een bevestigend antwoord en op de werkvloer een ontkennend antwoord opleveren, doordat de eerste daarbij primair uitgat van de formele structuur, de laatste daarentegen van de eigen practische ervaringen binnen de afdeling waar hij werkt.

Bovendien kan een verschillend oordeel over organisatiekenmerken binnen een organisatie verankerd liggen in de wijze waarop persoonlijkheid, karakterstructuur en cultuurpatroon, in de zin van heersende warden en normen binnen de betreffende referentiegroep, de oordelen en attitudes van het individu befnvloeden. Daardoor wordt tevens het oordeel van lemand over bepalde aspecten van de werkorganisatie beInvloed (W1111ams, 1966; Inkeles, 1971; Landsberger, 1971; Koot, 1980).

Daarnaast wordt opgemerkt dat in organisaties op verschillende punten en bij verschillende groepen verschillende informatie aanwezlg is (March en Simon, 1968). Er worden relaties verondersteld of gevonden tussen de perceptie van de werkomgeving en de reactie op deze werkomgeving (Brief en Aldag, 1975; Hulin en Blood, 1968; Dunham, 1977; Blood en Hulin, 1967; Newman, 1975; Inkson e.a., 1967; Naylor e.a., 1980).

Weinig kennis is echter aanwezig over het effect van verschillen in perceptie van organisatiekenmerken op het gedrag van 1 ndividuen en groepen in organisaties. Terecht merkt oldham (1976) dan ook op dat onderzoek gedaan moet worden naar het modererende effect van aspecten van de werkomgeving -zoals het organisatiek11- 
maat, de organisatiestructuur, belonings- en feedbacksystemen- op de relatie tussen de taakkarakteristieken en de motivatie, satisfactie en het gedrag in arbeidsorganisaties.

Het belang wan de kennis over deze verschlllende opvattingen is vanzelfsprekend als een organisatle gezien wordt als een 'negotlated order', waarbinnen afspraken gemaakt worden om voor de betrokkenen bevredigende resultaten te creëren (Veen, 1980a). De ultgangspunten voor deze onderhandelingen, pogingen om de organisatrle te beinvloeden en vorm te geven is afhankelijk van de perceptie van de organisatie (Hazewinke1, 1980; Welck, 1969).

Bekend is voorts dat verschillende persoonskenmerken het gedrag in organisaties beInvloeden, zoals een meer stedelijke of plattelandsachtergrond (Hackman en Lawler III, 1971; Turner en Lawrence, 1965), de aanwezigheid van hogere behoeften, zoals de behoefte aan persoonlijke groel (Brlef en Aldag, 1975), verschil in waardensystemen (Blood en Hulin, 1967) en leeftijd (Rhodes, 1983). Deze verschillende persoonskenmerken kunnen ook van invloed zijn op de perceptle van organisatiekenmerken, vandaar dat in dit hoofdstuk eerst zal worden Ingegaan op de verschillende gehanteerde metingen van organisatiekenmerken (3.2.) om vervo1gens over te gaan tot de beschrijving van enkele theoretische verklaringen ten aanzien van het ontstaan van mogelijke verschillen in beoordeling (3.3.). Tenslotte zal aangegeven worden op basis van welke variabelen de discrepantie tussen de beoordelingen berekend zal worden en volgens welke analysemethode deze discrepantfevarlabelen geanalyseerd zullen gaan worden ( 3.4 . tot en met 3.7.).

3.2. Verschl1lende benaderingen in het organlsatleonderzoek

Blinnen het organisatieonderzoek worden verschillende methoden en instrumenten gebrulkt ter typering van de kenmerken van de betreffende organisaties (Katz en Kahn, 1978; Drenth, 1980). Globaa1 gesproken kunnen twee algemene benaderingen onderscheiden worden, te weten: de institutionele en de questionnaire benadering (zle: Pugh en Payne, 1967; Pennings, 1973; Ha11, 1974; Calder e.a., 1976; Knowles, 1980; Koot, 1980; Algera, 1981).

a) De institutionele benadering

Hierbij wordt vooral gebruik gemaakt van feitelijk, "objectief" informatlematerlaal. Het betreft vooral informatle, die verworven wordt via eén informant, dle doorgaans in de top van de organisatie gezeteld is. 
Bij deze methode wordt beoogd om min of meer vast1iggende, objectieve gegevens te meten. Dit gebeurt dan bijvoorbeeld met behulp van: observatie, verslagen en rapporten, metingen, statistische gegevens (Pugh, 1963; Inkson e.a., 1967; Blau, 1968; Koot, 1980). Impliciet liggen aan deze aanpak een drietal assumpties ten grondslag:

- adequate meting van het kenmerk is mogelijk;

- het betreffende kenmerk is homogeen gespreid over de organisatie,

- het betreffende kenmerk is relatief stabiel in de tijd.

Een kritiekpunt ten aanzien van deze methode is dat betreffende organisatiekenmerken zelden discriminatief geformuleerd zijn zodat de kans groot is dat de betreffende informant daardoor $z 1 j n$ elgen waarden- en normen patromen in de verstrekte informatie legt (Pennings, 1973; Koot, 1980).

b) De questionnaire benadering

Door middel van deze methode beoogt de onderzoeker data te verkrijgen op basis van subjectieve informatie van individuen, middels aggregatie van individuele waarnemingen. Als kritiek op deze methode wordt veelal aangevoerd dat niet zozeer kenmerken van de werkorganisatie gemeten worden, alswel de eigen doeleinden van de werknemers. Bovendien kunnen door deze individuele benadering slechts in beperkte mate groepseigenschappen gemeten worden.

Om organisatiekenmerken te meten kunnen ook verschillende methodieken tegelijkertijd uitgevoerd worden. Zo kan aan de werknemers gevraagd worden of personeelsbeoordeling plaats heeft en op welke criterla deze beoordeling gebaseerd is, terwijl tevens gebruik gemaakt wordt van personeelsbeoordelingsgegevens en -formulieren. B1 j de beoordeling van lemand kan gelet worden op zijn elgen oordeel over het efgen functioneren, op het oordeel van de superieur, op de kwantitelt van zijn prestatie en op de kwalitelt ervan (cf.: Seashore e.a., 1960; Gulon, 1961; Porter en Lawler, 1968; Price, 1972).

Om de betrouwbaarheld van de onderzoeksbevindingen te vergroten vindt een aantal auteurs (onder andere Seashore e.a., 1960; Guion, 1961; Koot, 1980) het noodzakelijk om de gebrulkte begrippen, c.q. Indicatoren op meer dan een wijze te definiëren en te meten, bijwoorbeeld door de gegevens verkregen uit interviews te toetsen aan gegevens uit bedrijfsrapportages, statistieken en derge1ijke (Triangulation) (Becker, 1977; Patton, 1980). Ook andere auteurs pleiten ervoor om de data verkregen door meer subjectieve methoden te koppelen aan data verkregen middels andere methoden (Pennings; 1973; Inkson e.a., 1967). 
Een dergelljke vergelijklng van verschillende metingen ten aanzien van organisatiekenmerken is verricht door Pennings (1973). Deze auteur vergelijkt twee meettechnieken met elkaar: een instrument uit de institutionele benadering met een instrument uit de questlonnaire aanpak. Concluderend merkt hij op dat betwijfeld moet worden of de gemeten constructen wel unidimensioneel zijn gezlen de hoge intercorrelaties binnen één methode. De vraag is dan ook gerechtvaardigd of organisatlekenmerken, gegeven de veelal complextteit der varlabelen, niet beter gemeten kunnen worden met behulp van meerdere met1ngen (vergel1jk Dunette, $1963 \mathrm{a}$ en $b ;$ Smith, 1976).

Daarnaast $z i j n$ er met behulp van meerdere instrumenten vooral studies gedaan naar de meting van:

a) de directe werkongeving,

b) de individuele "performance".

ad a. De meting van de directe werkomgeving door middel van meerdere Instrumenten:

Algera (1981) geeft een goed overzicht van de ontwikkeling van de analyse van taakkenmerken. Veel aandacht is daarbij besteed aan de constructie van meetbare unldimensionele taakkenmerken. In een aantal onderzoeken is tevens de relatie tussen gepercipieerde taakkenmerken door enerzijds de werknemer zelf en anderzijds door andere beoordelaars (chef, observator) object van studie geweest.

Hackman en Lawler III (1971) gebrulkten vier meetprocedures:

- een steekproef van werknemers die een aantal vragenlijsten invulden ten aanzlen van een zestal taakkenmerken (variëtelt in activiteiten, autonomie, taakidentitelt, feedback, ongaan met anderen, mogelijkheden tot soclale en informele contacten);

- de (d1recte) chefs dle dezelfde vragenlijsten invulden;

- de onderzoekers, die na observatie, deze vragenlijsten invu1den;

- een objectieve codeer-procedure ontwikkeld door Turner en Lawrence.

De vergeliflking van deze vier methoden toont volgens de auteurs aan dat de oordelen van de werknemers zelf over hun taken goed overeenkomen met die van de andere waarnemingsprocedures, met ultzondering voor de kenmerken: feedback en de mate waarin binnen een taak omgegaan moet worden met anderen. Jenkins e.a. (1975) vergelijken de resultaten van werknemerinterviews met dle van getralnde observatoren ten aanzien van een zestal taakkenmerken. Vier van de zes maten ('variety', 'skills', 'autonomy' en 'pace 
control') hebben een redelijke convergente validiteit; twee maten echter niet: 'certainty' en 'cooperation'. 'Certainty' hing bij de werknemers nauw samen met 'autonomy' en bif de observatoren het sterkst met 'variety'. 'Cooperation" vertoont daarentegen een hoge samenhang met "variety' bij de werknemers; bij de observatoren correspondeert dit kenmerk echter niet met een van de andere. Opvallend zijn de hoge intercorrelaties tussen de waarnemingen van de observatoren, duidend op een substantiële methodische variantie. Daarnaast is er een aantal onderzoeken geweest naar de relatie tussen de perceptie van meer objectieve taakkenmerken en meer subjectieve affectleve responsen, zoals satisfactie (Brief en Aldag, 1975; Sims e.a., 1976; Dunham, 1977) en intrinsieke motivatie (Cooper, 1973; Oldham, 1976). Uit deze onderzoeken bleek dat de betreffende relatie sterk belnvloed werd door zowel individuele verschillen, als door niet taakgerichte omgevingskenmerken.

Bovendien is er onderzoek gedaan naar relatie tussen plaats en taken van de respondent in de arbeldsorganisatie enerzijds en een aantal organisatiekenmerken anderzijds. Zo hebben Payne en Mansfield (1973 en Mansfield en Payne, 1977) een onderzoek beschreven naar individuele varlaties in de perceptie van het organisatieklimaat. Zij concluderen dat er meer variatie in percepties is binnen grotere dan binnen kleinere organisaties. Werknemers die een hogere plaats innemen in de organisatiehiërarchle zien de organisatie vaker als:

- minder autoritair (een kleinere afstand tot de baas, open-mindedness en grotere zorg van het management voor het personee1), - meer mogelijkheden tot interessant en uitdagend werk (betere toekomstmogelijkheden, meer intellectuele taakoriëntatie),

- vriendelijker (hogere mate van altruisme en een geringere interpersoonlijke agressie),

- meer innovatief.

Op grond van deze resultaten concluderen deze auteurs, dat de variatles in percepties beschouwd kunnen worden als betekenisvolle parameters van het organisationele systeem. Gelijksoortige bevindingen ten aanzien van hoger geplaatsten In de hiërarchie z⿺jn in simulatiespelen gedaan door Van der Meer (1982).

Een onderzoek van Newman (1975) resulteert in de bevinding dat verschillen in attitudes ten opzichte van iemands werkomgeving zowel beInvloed worden door objectieve persoons-elgenschappen, als door objectieve elgenschappen van de organisatie. De auteur constateert dat de houding ten opzichte van het elgen werk niet of nauwelijks befnvloed wordt door sexe of opleiding, maar vooral 
door de leeftijd en de diensttijd, het hièrarchisch niveau, de afdeling waar gewerkt wordt en de eigen werkgroep. De perceptie van de werkomgeving 1 s meer een functie van de plaats van lemand in de werkomgeving dan $v$ an lemands persoonlifkheldsstructuur. Gesteld kan worden dat het gedrag van taakultvoerders meer bepaald wordt door de perceptie van de elgen functies dan door objectleve kenmerken van die functle (Hackman en Lawler III, 1971).

ad b. De meting van de individuele taakultvoering door middel van meerdere instrumenten:

Hierbij worden veelal twee of meer verschillende beoordelaars met elkaar vergeleken. In het merendeel der gevallen betreft het dan een vergelijking tussen self-ratings, peer-ratings en superiorratings. Heneman (1974) concludeert dat de self-ratings minder mildheld en meer variantle vertonen dan de superiorratings. Een onderlinge vergelifking toont een convergente validiteit voor de aspecten "planning, supervising, negotiating, representing en overall effectiveness', maar niet voor 'investigating, coordinating, evaluating and staffing". Volgens de auteur bevatten self-ratings minder halo-error dan superior-ratings. Holzbach (1978) constateert daarentegen dat self-ratings een milder oordeel geven dan peer- en superior-ratings. Tevens constateert hij een groot halo-effect. Zammuto (1982) toont aan dat dit mildheldseffect vooral bestaat ten aanzien van afzonderlijke taak1tems. Er zijn volgens deze auteur twee effecten in hoofdzaak verantwoordelijk voor de verschillen tussen raters, namelijk het halo-effect en verschilien tussen raters in de weging van de belangrijkste performance criterla voor het meten van de taakuitvoering .

Opvallend is dat herhaaldelijk wordt opgemerkt dat organisatiekenmerken belangrijke intermedlërende factoren zijn, ten aanzlen van zowel takbeoordelingen als van veranderingen in de werkorganisatie (Jobentichment, experimenten in humanisering van de arbeld). Desondanks wordt slechts in een gering aantal onderzoeken geprobeerd om -vanult de verschillende optieken, zoals die binnen een organisatie bestaan- te onderzoeken of er sprake is van verschilien in benadering en, indien deze versch11len gevonden worden, waar de bron voor dergelijke verschillen $11 \mathrm{gt}$ (zie: Inkson e.a., 1967; Hulin en Blood; 1968; Argyr1s, 1973; Newman, 1975 ; Dunham, 1977).

Mede gezlen de bovengenoemde bevindingen ten aanzien van ver- 
schillen in beoordelingen zal in dit onderzoek geanalyseerd worden in welke mate de beoordelingen van kenmerken van de organisatiestructuur beīnvloed worden door de plaats van de respondent in de organisatie. Voor de in dit onderzoek gemeten variabelen zal, ondanks de beperkingen er aan, het begrip organisatiekenmerk gehanteerd worden (Veen, 1980b) en wel omdat gepoogd is de variabelen te meten naar hun objectieve en over langere tijd bestaande aanwezigheid, onafhankelijk van de plaats en functle van de beoordelaar. De structuur van de organisatiekenmerken, zoals die uit de interviews naar voren komt, zal opgevat worden als een structuur die vorm krijgt door de perceptie, die de betroffen individuen hebben van de organisatie en van patronen zoals die binnen de organisatie bestaan (Calder e.a., 1976). Daartoe is gekozen voor een benadering waarin, om de gewenste organisatiekenmerken te meten, gebruik gemaakt wordt van diverse informanten. Ten dele zijn dezelfde vragen gesteld aan het hoofd van de productle, het hoofd van de afdeling personeelszaken en aan leden van een personeelsvertegenwoordiging. Bovendien zijn de vragen naar hinderlijke aspecten $1 \mathrm{n}$ de arbeldsomstandigheden ook gesteld aan een representatieve steekproef werknemers uit de betreffende organisatie. De vragen hadden niet zo zeer betrekking op de mening van de geinterviewde ten aanzien van verschillende aspecten (indicatoren) van de werkorganisatie, maar vooral op formele, objectieve aspecten van de organisatiestructuur.

\subsection{Discrepantie: een begripsverheldering}

De plaats van de respondent in een arbeidsorganisatie kan de beoordeling van organisatiekenmerken of kenmerken van de arbeidssituatie beinvloeden. Dit verschil in beoordeling kan haar weerslag hebben op reacties van individuen, c.q. groepen op zowel het gedrag van andere groepen, als op organisatieveranderingen.

Dit verschil in beoordeling wordt discrepantie genoemd. Daarbij worden twee verschillende vormen van discrepantie onderschelden.

a. Discrepantie als organisatievariabele.

De grootte van de discrepantile wordt bepaald door een sommatie van gevonden verschillen op verscheldene-op de organisatie of op de arbeidssituatie betrekking hebbende- items. Deze discrepantiemat is een kwantitatieve benadering van de mate warin binnen een bedrijf overeensteming of verschil bestaat tussen categorieën beoordelaars. Deze maat kan daarmee een uitdrukking zijn 
van de kwaliteit van de communicatie, ofschoon daarmee geen informatle over de inhoud van de discrepantie gegeven wordt. Analoog aan de bevindingen van Payne en Mansfield (1973 en Mansfleld en Payne, 1977) wordt verondersteld dat deze maat daardoor zelf weer als een organisatiekenmerk kan worden beschouwd. In hoofdstuk 5 zal deze discrepantlemat gerelateerd worden aan andere kenmerken van de arbeldsorganisatie en arbeidssituatie. De discrepantle $1 \mathrm{~s}$ op drle nilveau's gemeten, namelijk:

- de discrepantie tussen de beoordelingen van het management en het hoofd personeelszaken: Dman-pz;

- de discrepantie tussen de beoordelingen van het management en leden van de personeelsvertegenwoordiging: Dman-pv;

- de discrepantie tussen het hoofd personeelszaken en leden van de personeelsvertegenwoordiging: Dpz-pv.

De verschillende vormen van discrepantie vormen een uitdrukking van de verschillen in afstand tussen diegenen, die verantwoorde$11 j k$ zijn voor het in de organisatie gevoerde beleid, ten aanzien van de productie (management), ten aanzien van personeelszaken en leden van de personeelsvertegenwoordiging. Als zodanig zijn het institutionele afstandsmaten tussen diegenen, die uit hoofde van de beklede functie over een grote mate van beInvloedingsmogelijkheden of besllssingsmacht beschikken.

b. De discrepantie op item-niveau

De Inhoud van de discrepantie kan geanalyseerd worden door op itemniveau de beoordelingen van de verschillende beoordelaars met elkaar te vergelijken. Op een dergelijke wijze kan geconstateerd worden ten aanzien van welke kenmerken van de arbeidsorganisatie of arbeldssituatie overeenkomsten en verschillen tussen beoordelaars bestaan. Deze discrepantie-analyses op itemniveau worden in de hoofdstukken 6 en 7 beschreven. Bij die analyses zal vooral ingegaan worden op de inhoudelijke aspecten van de verschillen tussen beoordelaars.

3.4. Theoretische oorzaken yoor discrepantie

Beoordelingen van situaties en organisatieaspecten door een individu, zijn producten van onderling overleg en afstemming, die zowel de objectleve feiten, als de invloed van anderen weergeven en een effect $z i j n$ van de subjectieve kenmerken en vermogens van het betreffende individu (vergelijk Backman, 1982; Bremer, 1983). De linvloed van het werk en de werksituatie op de ontwikkeling van 
een individu wordt wel beroepssocialisatie genoemd (Volpert, 1975). Blj dit fenomeen is de invloed van onder andere de volgende factoren te onderkennen:

- het aanleren van kundigheden en vaardigheden,

- de Invloed van technologische en economische ontwikkeling (technologisering, recessies, rationalisering e.d.),

- de specifieke life-events (werkloosheld, ongevallen, werken met bepaalde chefs of collega's e.d.).

- het reilen en zellen op de arbeidsplaats (arbeldstempo, het appèl op al of niet aanwezige (in) competenties e.d.).

De beroepssocialisatie-these stelt dat verschillen in effecten van beroepssocialisatie tussen personen verklaard kunnen worden door invloeden vanult de arbeld(-ssituatie). De vorm en inhoud van deze verschillen moeten mede gedeeltelijk verklaard worden vanuit de persoonlijkheldsstructuru, ofschoon deze laatste ook weer beinvloed wordt door de arbeldssituatie zelf. Er is dus sprake van een reciproke interactie tussen de persoon en zijn werkomgeving (Frese, 1982).

In veel arbeldssituaties zullen, althans ten dele, de ervaringen met de arbeidsorganisatie van werknemers op eenzelfde hiërachische niveau sterk met elkaar overeen komen. Eenzelfde soort ervaring kan leiden tot een min of meer gelljkvormig systeem van normen en waarden, zoals dat door en binnen de arbeldssituatie gestalte krijgt (Volpert, 1975).

Vanuit dit concept van beroepssocialisatie is het begrijpelijk dat Popitz e.a. (1957), Goldthorpe e.a. (1968a, 1968b, 1969) tot de bevinding komen dat handarbeiders andere waarden en normenpatronen vertonen dan kantoorarbelders of dat deze juist naar e1kaar toegroelen (voor een overzicht van dergelijke bevindingen zie: van Beek, 1973 en Nijhuis, 1975).

Onvoldoende verklaren deze theorleën welke Implicaties versch11len in arbeldssituaties hebben op verschillen in het denken over de elgen arbeldsorganisatie. Eventuele discrepanties tussen beoordelaars kunnen immers tenminste een drietal verschillende bronnen hebben, namelijk:

a. verschil in referentiekader,

b. beperktheid van de interne communicatie- en informatiestructuur,

c. systematische vertekening .

ad a. Verschil in referentiekader

Verschillen in social-culturele omgeving, in cultuurpatroon, in verwachtingen over wat in een soortgelijke organisatie gebruike- 
lijk is, in individuele opvattingen en attitudes beinvloeden het oordeel over bepaalde aspecten van de werkorganisatie (Williams, 1966; Inkless, 1971; Argyr1s, 1973; Schein, 1975 e.a.).

De optlek waarmee door de beoordelaars naar de werkorganisatie gekeken kan worden is zeer divers. In hun beoordeling kunnen verschillende referentles gehanteerd worden:

- een beoordeling kan gegeven worden in vergelifking met de arbeldssituatie bif andere, soortgelifke bedrifven.

- een beoordeling kan gegeven worden in vergelijking met de meest optimale arbeldssituatie.

- een beoordeling kan gegeven worden vanult de eigen positie en activiteiten van een beoordelaar in het bedrijf en ten dienste van deze elgen activiteiten en positie. Voor de werkgever wordt de optiek bepaald door de noodzaak van een zo optimaal mogelijk functionerende organisatie. Ten aanzien van de vragen naar specifleke organisatiekenmerken kan dit betekenen dat een verdedigende houding wordt aangenomen, zodat de organisatie en het organisatiebeleld zo positief mogelljk wordt beschreven. Voor de werknemersvertegenwoordigling $k$ an het juist een mogelijkheld zijn om zichzelf te profileren en zodoende een aanleiding vormen om de geconstateerde zwakke punten, fellen in het systeem, (meer) te benadrukken.

- een beoordeling kan gegeven worden met het oog op de, door de beoordelaar, gepercipieerde verwachtingen van de interviewer. De personeelsvertegenwoordiging kan bijvoorbeeld negatievere beoordelingen geven, omdat gedacht wordt, dat de interviewer dat van hem verwacht.

- een beoordeling kan gegeven worden als evaluatie van het elgen functioneren. Met name vragen naar concreet gevoerd beleld kunnen lelden tot defensiemechanismen bij de groep, die zich verantwoordelijk voelt voor dat beleid. Beleidsintenties, al of niet formeel geformuleerd, worden geacht het beleid te zijn, ofschoon dit (nog) niet altijd het geval behoeft te zijn.

- tenslotte zullen de objectief bestaande verschilien in macht binnen de organisatie eveneens lelden tot verschillende uitgangspunten en interpretaties (Bacharach en Lawler, 1980).

Uit deze verschlllende referentlekaders blijkt des te meer dat verschillen in beoordelingen niet uitsluitend 'subjectief' van aard behoeven te $21 j \mathrm{n}$, maar eveneens een objectieve weergave kunnen vormen van verschillen in de eigen positie in de arbeidsorganisatie. 
ad b. Beperktheld van de interne communicatie- en informatiestructuur

Elke grotere organisatie of elk sociaal systeem impliceert een beperking van het totale aantal aan communicatiemogelijkheden. Zonder het aambrengen van de nodige communicatiekanalen en patronen is er eventueel wel veel overdracht van woorden maar daarmee nog niet van betekenis. Het aanbrengen van dergelijke communicatiekanalen en patronen houdt overigens toch nog de beperking in dat bepaalde informatle wel wordt doorgegeven en andere niet. De volgende problemen kunnen daarbij geconstateerd worden:

- Het optreden van breuken en/of vernawingen in het communicatiepatroon. De mate waarin men is ingelicht over wat er zich binnen de werkorganisatie afspeelt is veelal beperkt. Bekende communicatiestoornissen $z i j n$ : het middenkader geeft bepaalde berichten niet door; het hogere management sluit zijn oren voor klachten op lagere niveau's; op de laagste niveau's wordt informatie van bovenaf genegeerd of naar boventoe niet gegeven.

- Eenzelfde begrip kan op meerdere verschillende wijzen gebruikt worden of verschillende begrippen kunnen eenzelfde betekenis hebben.

- Er bestaan verschillen tussen de formele en informele arbeidsorganisatie. Het werkelijk gedrag van individuen of groeperingen wijkt af van de voorgeschreven activiteiten. Vaak is dit positief en komt het slechts dan aan het daglicht als er storingen optreden in het productieproces, onvoldoende productie in kwantiteit of kwaliteit wordt afgeleverd en dergelijke.

- Een vierde probleem is dat in een arbeidsorganisatie nlet op gelifke wijze met dezelfde organisatieregels en -normen gewerkt wordt. Invoering van werkoverleg kan binnen het gehele bedriff opgezet $z i j n$, maar kan na een perlode warin het gefunctioneerd heeft binnen de ene afdeling springlevend zijn en binnen een andere afdelling niet. Maar ook de wijze waarop aan de regels en normen uitvoering wordt gegeven kan verschillend zijn.

\section{ad c. Systematische vertekening}

Analoog aan het onder twee genoemde probleeem dat dezelfde begrippen verschillende betekenis hebben, kan het ook zijn dat de gebruikte vragen11jsten in hun formulering van vragen ten aanzien van verschillende organisatiekenmerken onvoldoende helder waren. Bij de analyses zal dus eveneens gekeken moeten worden naar de convergente validiteit van het gebruikte begrippenapparaat. BIj een onvoldoende convergente validitelt kan discrepantie ontstaan 
op basls van statistische ruls.

Deze ruls kan ook ontstaan door systematische blas van de onderzoekers (interviewee-effect), evenals door bias in de gevolgde meetprocedures, het halo-effect (Kerlinger, 1973; Holzbach, 1978; Drenth, 1980, Landy e.a., 1982; Mathan en Lord, 1983; Schwab en Wichern, 1983). Het interviewee-effect is getracht te controleren door te voorkomen dat ển enkele interviewer alle interviews bij cén groep van beoordelaars deed (zle: 2.2.4.). Het halo-effect, dat vooral geconstateerd wordt bij personeelsbeoordelingen, ontstaat wanneer een geinterviewde niet differentieert tussen verschillende dimensies of indicatoren, met andere woorden: wanneer deze vanuit een globaal, overa11-oordeel een positieve of negatleve beoordeling geeft van de verschillende dimensies of indil catoren.

Cooper (1981) geeft een overzicht van de pogingen om het haloeffect te controleren. De auteur stelt dat alle pogingen slechts ten dele succesvol zijn geweest. Bovendien blijkt een reductie van het halo-effect samen te gaan met een verminderde nauwkeurigheld van de metingen. Het is namelijk mogelijk dat een onder11 ggende set relaties met een algemeen effect eveneens verdwijnt (Landy e.a., 1982). Een dergelijke algehele effectiviteitsfactor, die de taakuitvoering beschrijft of een algemene factor, die de arbeidsomstandigheden weergeeft, hoeft geen foutfactor te $z i j n$. Zo stelt Hulln (1982) dat een algehele taakuitvoeringsfactor gepostuleerd zou kunnen worden welke bepaald wordt door mense1ijke capacitelten en beperkingen (vergelijk ook Murphy, 1982). Somige onderzoekers spreken dan ook van twee soorten halo-effecten: een valide en een Invalide halo-effect (Cooper, 1981; Bartlett, 1983). Bij de beoordeling van organlsatiekenmerken $11 j \mathrm{kt}$ een vorm van systematische vertekening mogelijk die $11 j k t$ op dit halo-effect. Beoordelingen kunnen verschillen, doordat bij de betreffende beoordelaars verschillende (positieve of negatieve) algemene beoordelingen van organisatieaspecten bestaan. Dit kan veroorzaakt worden door een verschil in normen en waarden (z1e: ad 1), mar kan ook ontstaan vanult een al dan niet verdedigende optlek. In dit latste geval zullen de scores ten aanzien van de verschillende items systematisch van elkaar moeten verschillen. B1f de analyses in de hoofdstukkem $5 \mathrm{t} / \mathrm{m} 7 \mathrm{zal}$ echter uitsluitend de concepten systematische vertekening of bias gehanteerd worden, omdat het "halo-effect" een typerende meetfout is voor personeelsbeoordelingen.

$\mathrm{Na}$ deze korte beschrijuling van een aantal mogelijke oorzaken van discrepanties in beoordelingen zal allereerst aangegeven dienen 
te worden ten aanzien van welke variabelen meerdere beoordelingen aanwezig zijn en hoe daaruit resulterende discrepanties zullen worden geanalyseerd.

3.5. De discrepantievariabelen

De vragen, die eensluidend aan verschillende informanten gesteld zijn, hebben vooral betrekking op:

- de mate waarin werknemers hinder ondervinden van verschillende arbeidsomstandigheden,

- de aanwezigheid van werkoverleg,

- de aanwezigheid van een beoordelingssysteem,

- karakteristieken van het personeelsbeleid.

Deze vragen hebben in het algemeen geen betrekking op het oordeel van de betreffende informant over het functioneren van het beoordelingssysteem, de tevredenheld over de werksituatie, maar zij proberen in te gaan op een antal objectief vaststelbare organisatlekenmerken. Vandaar dat een aantal vragen naar de meningen van de verschillende beoordelaarscategorieën over bepaalde aspecten $v$ an het gevoerde beleld niet in de berekening van deze discrepantievariabelen zijn opgenomen. Een groot aantal vragen heeft betrekking op de mate waarin werknemers hinder ondervinden $v$ an bepaalde arbeidsomstandigheden en arbeidssituaties. Ook in dit geval is geprobeerd om zoveel mogelijk afstand te nemen van de eventuele directe eigen ervaring en is getracht deze hinder te objectiveren.

De items, zoals weergegeven in onderstaand overzlcht, hebben allen een bijdrage geleverd aan de samenstelling van de overal1discrepantiemat $v$ an de arbeidsorganisatie (zie: 3.7.). Een aantal kernvragen (specifieke organisatiekenmerken) wordt daarnaast afzonderlijk geanalyseerd ten aanzlen $v$ an de convergente validitelt en de mate van verschil en overeenkomst tussen beoordelaars (volgens de methode beschreven in 3.6. (z1e: hoofdstuk 6 en 7).

Bij elk van de categorie beoordelaars is een uitvoerige, per categorie grotendeels verschillende, vragenlijst afgenomen (per vragenlijst ruim 100 items).

De volgende groepen van vragen zijn gesteld aan de drie verschillende Informanten. 
* Aan elk van de beoordelaars zijn vragen gesteld over de arbeldsomstandigheden ( 23 items): "We1k deel van het direct ultvoerend personeel heeft hinder van specifleke, mogelljk gezondheidsbedreigende omstandigheden (dan volgen een 23-tal items: trilling, ongevallenrisico, koude/warmte, temperatuurwisselingen, stof, lawaal, vuil, vocht/tocht, stank, gas/damp, straling, onbekende stoffen, lichamelijk zwaar werk, slechte lichaamshouding, geestelljk zwaar werk, ploegendienst, weinig vrijheld om het werk zelf in te delen, te hoog arbeidstempo, eentonig werk, arbeidsplaats-onzekerheid, werksfeer, giftige stoffen en onduidelijke taakinhoud.

De beoordelaar kon antwoorden middels een 5-puntsschaal, variërend van nlemand $(=1)$ tot ledereen $(=5)$.

Naast de vragen over de arbeldsomstandigheden, die aan alle beoordelaars $z 1 j n$ voorgelegd, zijn de volgende vragen aan slechts twee van de drie beoordelaars gesteld:

* Aan de hoofden van de productie en personeelszaken (inclusief met de arbeldsomstandighedenitems, in total 24 items):

1. Zijn er meetsystemen in de organisatie on eventueel gezondheldsbedrelgende factoren op te sporen ( 1 item).

* Aan de personeelsvertegenwoordiging en het hoofd van de productle gestelde vragen (in totaal 35 items):

1. Is er in het bedrijf in de perlode 1977-1980 sprake geweest van (5 items):

-werkt1jdverkorting,

-natuurilike afvioeiling,

-reorganisatie,

-ontslagen,

-tijdelijk werken in ploegendienst?

2. Hebben veranderingen in taken zoals die in het bedrijf plats gevonden hebben geleld tot ( 3 items):

-verhoging arbeidstempo,

-functieverruiming,

-functieverenging?

3. Hebben zich in deze vestiging ontwikikelingen voorgedaan op het gebled van ( 3 items):

-mechanisering,

-automatisering,

- produc tontwikkeling? 
4. Zijn er in de organisatie meetsystemen om eventueel gezondheidsbedreigende factoren op te sporen ( 1 tem)?

* Aan de personeelsvertegenwoordiging en het hoofd personeelszaken (49 items):

1. Beoordelingssysteem (5 items):

- Ce aanwezigheld $v$ an een beoordelingssysteem in de arbeldsorganisatie,

-op welke wljze vindt dat plaats,

-met welk doel,

-voor welk deel $\mathrm{v}$ an het personeel,

-wordt daarbij rekening gehouden met ziekteverzuim van de werknemer ?

2. De personeelsbezetting ( 10 items):

-de personeelssituatie in 1977 (te krap, voldoende of te ruim),

- hoe was dat in 1980 ,

-zijn er onvervulbare vacatures,

-in welke mate wordt in deze vestiging verplicht overgewerkt,

-in welke mate wordt in deze vestiging vrijwillig overgewerkt,

-In welke mate wordt in deze vestiging reguller werk uitbesteed,

-in welke mate worden in deze vestiging orders geannuleerd of afgewe zen,

- In welke mate ontstaan er in deze vestiging wachttijden of worden levertijden langer,

-in welke mate wordt er in deze vestiging gewerkt met inleenkrachten, koppelbazen e.d.,

-in welke mate wordt in deze vestiging gewerkt met werknemers op tijdelijk contract/TAP-pers?

3. Werkoverleg ( 6 items):

-de aanwezigheld van werkoverleg in de arbeldsorganisatie,

-met vaste agenda,

-schriftelijke verslaglegging,

-hoe functioneert het werkoverleg in vergelijking met 1977 ,

-wordt er bij het werkoverleg ook over zlekteverzuim gesproken,

-functioneert het werkoverleg naar uw mening goed?

4. Zijn er in de organisatie meetsystemen om eventuele gezondheidsbedreigende factoren op te sporen ( 5 items):

-de aanwezigheid van dergelijke systemen in de arbeldsorganisatie,

-op het terreln van temperatuur, 
-op het terrein van stof/lawaal,

-op het terrein van ongevallen,

-11chamel1jk of mentaal zwaar werk?

3.6. De analyse van de discrepantievariabelen

Bij de analyse van de discrepantlevariabelen kunnen verschillende vormen van discrepantie onderschelden worden.

a. Op de eerste plaats $1 \mathrm{~s}$ een vorm van discrepantie mogelijk, waarbij tussen de informanten absolute verschillen in scores blljken te bestaan, evenwel zonder dat het onderlinge patroon van deze verschillen over de organisatie heen blijkt te verschilen. Statistisch vindt dit zijn weerslag in een hoge correlatie en significante verschillen tussen de gemiddelden. Een dergelijk effect kan zowel veroorzaakt worden door systematische vertekening (bias), als door het feit dat de informanten een verschillende referentie als vergelifkingspunt hanteren. Zo kan ten aanzien van de arbeidsomstandigheden het management de omstandigheden in de eigen bedriffstak als referentlepunt nemen, terwij1 de werknemers in de directe productie de arbeidsomstandigheden van de werknemers op kantoor als referentlepunt beschouwen. Dit kan leiden tot zeer verschillende oordelen, die echter over de organisaties heen wel eenzelfde patroon opleveren.

b. Op de tweede plaats is een discrepantie mogelijk waarbij sprake is van een lage correlatie, dat wil zeggen: er is geen overeenkomst in het beoordelingspatroon tussen de informanten, gepaard gaande met een significant verschil tussen gemiddelden. Dit impliceert dat er een verschil in beoordeling is, bijwoorbeeld naar de mate warin werkoverleg is doorgevoerd. Dat deze verschillen niet systematisch zijn wil zeggen dat er nlet zozeer sprake is van een vorm van blas, doch dat er binnen de arbeldsorganisatie verschillen bestaan over de mate warin in casu werkoverleg is doorgevoerd. Deze discrepanties betreffen dan verschillen die hun oorzaak vinden in de interne organisatie en die nlet over de bedrijven heen met elkaar corresponderen. Maar ook kan een dergelijke discrepantle verklaerd worden vanult een gebrekkige convergente validiteit of door de aanwezigheid van verschillen tussen organisaties ten aanzien van de kennis over de eigen arbeldsorganisatie.

c. Dit geldt eveneens voor de derde vorm van discrepantie, te weten een lage correlatie en geen verschil tussen gemiddelden. 
Dit duidt op een relatief hoge overeensteming is ten aanzien van de mate warin een bepalde situatie zich in de organisatie voordoet, zonder dat er van een systematisch patroon sprake is. Ook hier lijkt gebrek aan informatie binnen de arbeldsorganisatie over kenmerken van deze arbeldsorganisatie de meest waarschijnlijke bron.

Ter verduidelijking van deze verschillende vormen van discrepantie zal in figuur 3 geprobeerd worden deze verschillende mogeIljkheden grafisch weer te geven.

figuur 3. Vormen van discrepantie tussen beoordelaars.
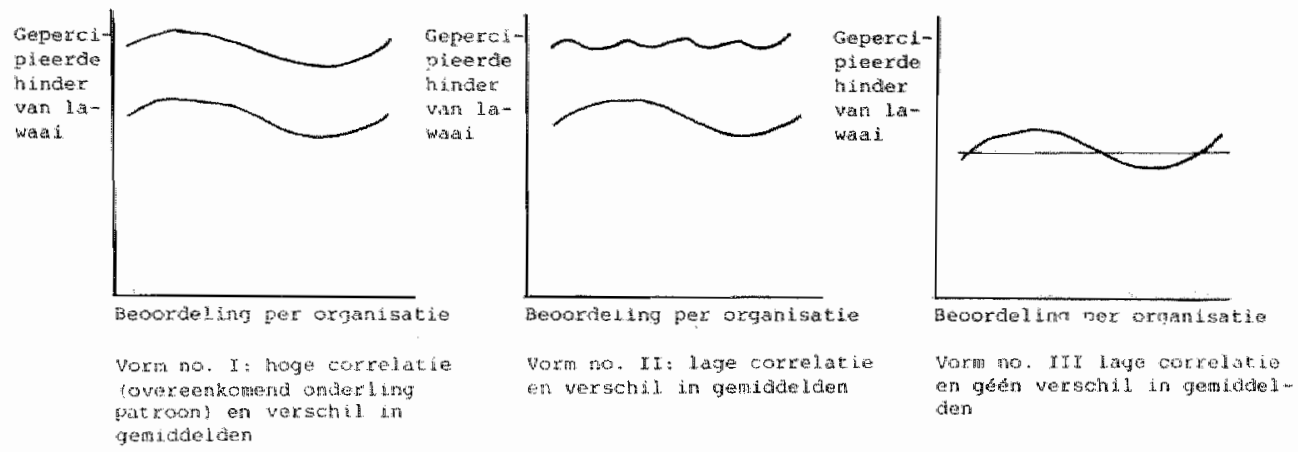

In deze benadering kunnen voor dit onderzoek twee belangrifke aspecten onderscheiden worden:

- door middel van de verschillende metingen kan geanalyseerd worden of er sprake is van een overall-discrepantlemat per organisatie, met andere woorden of de mate van discrepantle een organisatiekenmerk is (hoofdstuk 5),

- door de scores van de verschillende raters op de afzonder11jke items te vergelijken kan onder meer ontdekt worden welke organisatie-aspecten het meest gevoelig zijn voor discrepantie en in welke mate deze discrepantie resulteert uit een gebrekkige concensus tussen de beoordelaars over de gebruikte begrippen (hoofdstuk 6 en 7 ). 
Voor het eerstgenoemde aspect zijn, conform aan wat beschreven is in 2.3., per organlsatie een drletal discrepantiematen berekend, te weten:

- de discrepantie tussen de beoordelingen van het management en die van het hoofd personeelszaken: de Dman-pz;

- de discrepantle tussen de beoordelingen van het management en die van leden van de personeelsvertegenwoordiging: de Dman-pv;

- de discrepantie tussen de beoordelingen van het hoofd personeelszaken en die van een aantal leden van de personeelsvertegenwoordiging: de Dpz-pv.

In de volgende paragraaf (3.7.) wordt de berekeningswijzen van deze discrepantiematen beschreven.

Ten behoeve van het tweede aspect, de vergelijking per item, wordt een analysetechniek gehanteerd, die voor het eerst beschreven 1 s door Campbell en Fiske (1959): een analyse met behulp $v$ an de Multitrait-Multimethod Matrix (MTMM-matrix).

De latste paragraaf $(3.8$.$) van dit hoofdstuk bevat een beschrij-$ ving van deze technlek.

3.7. De discrepantiemat

De mate warin overall-discrepantie tussen de personeelsvertegenwoordiging, de afdeling personeelszaken en het management in een arbeldsorganisatie voorkomt heeft, als organisatiekenmerk, zijn oorzaak of oorzaken binnen de arbeidsorganisatie.

De berekening van deze discrepantievariabele per organisatie is gebeurd in een drietal stappen; deze stappen zullen bij wijze van voorbeeld worden gevolgd aan de hand $v$ an de berekening $v a n$ de Dman-pv (de discrepantie tussen de beoordeling van het management en die van de leden van de personeelsvertegenwoordigling).

De Dman-pv is berekend over 35 ittems:

1. Elke 1temwarde, gegeven op basis van de beoordeling $v a n$ de personeelsvertegenwoordiging, is afgetrokken van de waarde op datzelfde item verkregen op basis van de beoordeling van het management.

Door de discrepantie per item te kwadrateren wordt voorkomen dat positleve en negatieve scores tegen elkaar wegvallen en weegt een grotere discrepantie duidelijk zwaarder dan een kleine discrepantie. 


$$
D_{n}=\left(I_{m a n_{n}}-I_{p v_{n}}\right)^{2}
$$

$\mathrm{N}=1-35$ (aantal items, die zowel gesteld zijn aan management als aan de personeelsvertegenwoordiging), Iman $n$ "N-item, gescoord door het management.

Ipvn $_{n}=\mathrm{N}-1$ tem, gescoord door de personeelsvertegenwoordiging.

2. Vervolgens zijn deze D-waarden onderling gestandariseerd. Bepaalde items (bijvoorbeeld die gescoord op een 5-puntsschaal) boden meer mogelijkheld tot discrepantie dan andere items (bijvoorbeeld die gescoord op een drie-punts schaal).

$$
\mathrm{GD}_{\mathrm{n}}=\frac{\mathrm{MD}_{\mathrm{n}}-\mathrm{D}_{\mathrm{n}}}{\mathrm{SDD}_{\mathrm{n}}}
$$

$\mathrm{GD}_{\mathrm{n}}$ : gestandariseerde $\mathrm{D}$ op $\mathrm{N}^{\mathrm{e}}$-1 tem

$\mathrm{MD}_{\mathrm{n}}$ : gemiddelde waarde $\mathrm{D}$ op $\mathrm{N}^{\mathrm{e}}-1$ tem

$\mathrm{SDD}_{\mathrm{n}}$ : standaard deviatie $\mathrm{D}$ op $\mathrm{N}^{\mathrm{e}}-\mathrm{i}$ tem

Bij deze berekening is opnleuw gezorgd voor de gelijke richting van de discrepantiewarden; dit is gebeurd door bif de GD een waarde van 100 op tẹ tellen.

3. Tenslotte is per arbeidsorganisatie het gemiddelde berekend van de gestandariseerde discrepanties per item.

$$
\mathrm{D}_{\mathrm{man}-\mathrm{pv}}=\frac{\sum_{1}^{35}\left(\mathrm{GD}_{\mathrm{n}}+100\right)}{35}
$$

$N=1-35$

Door de berekening, zoals deze in stap 2 heeft plaats gevonden, zullen de ufteindelijke waarden van de discrepantievariabelen variëren rond de 100 .

Deze discrepantievariabelen zullen vervolgens gerelateerd worden aan een aantal theoretisch belangrijke organisatievariabelen, die in hoofdstuk 4 beschreven zullen worden. In dat hoofdstuk zullen ook op basis van die organisatiekenmerken en op basis van de in dit hoofdstuk geformuleerde veronderstellingen weergegeven worden over de samenhang tussen die organisatiekenmerken en de discrepantievariabelen. De analyse van deze discrepantievariabelen als afhankelijke varlabelen zal vervolgens in hoofdstuk 5 beschreven worden. 
3.8. De Multitrait-Multimethod Matrix

Zowel on de vallditelt van de gebrulkte concepten te analyseren als om te analyseren in welke mate eventuele response-sets in het materlaal aanwezlg zijn, is de Multitrait-Multimethod Matrix (MTMM-matrix) een goed hulpmiddel.

Het principe $v$ an de MTM-matrix is een vergelijking van de correlaties over de gemeten traits, indicatoren e.d. tussen en binnen observatoren, in dit geval beoordelaars. Zij is voor het eerst beschreven door Campbell en Fiske (1959). Ander onderzoek waarbij gebruik is gemaakt $v$ an de MTMM-matrix is Alderfer (1967), Lawler III (1967), Boruch e.a. (1970), Kavanagh e.a. (1971), Pennings (1973), Borman (1974), Heneman (1974), Hunter en Schmidt (1978), Holzbach (1978) en Johnson e.a. (1982).

Aan de hand van een voorbeeld zullen wij de te volgen methode beschrljven met gebruik van een tabel ult het artikel van Lawler III (1967) gegeven is.

Tabe1 3.1.

Criteriumcorrelaties bij Tucker, Cline en Schmitt (1967) (geciteerd in: Lawler, 1967).

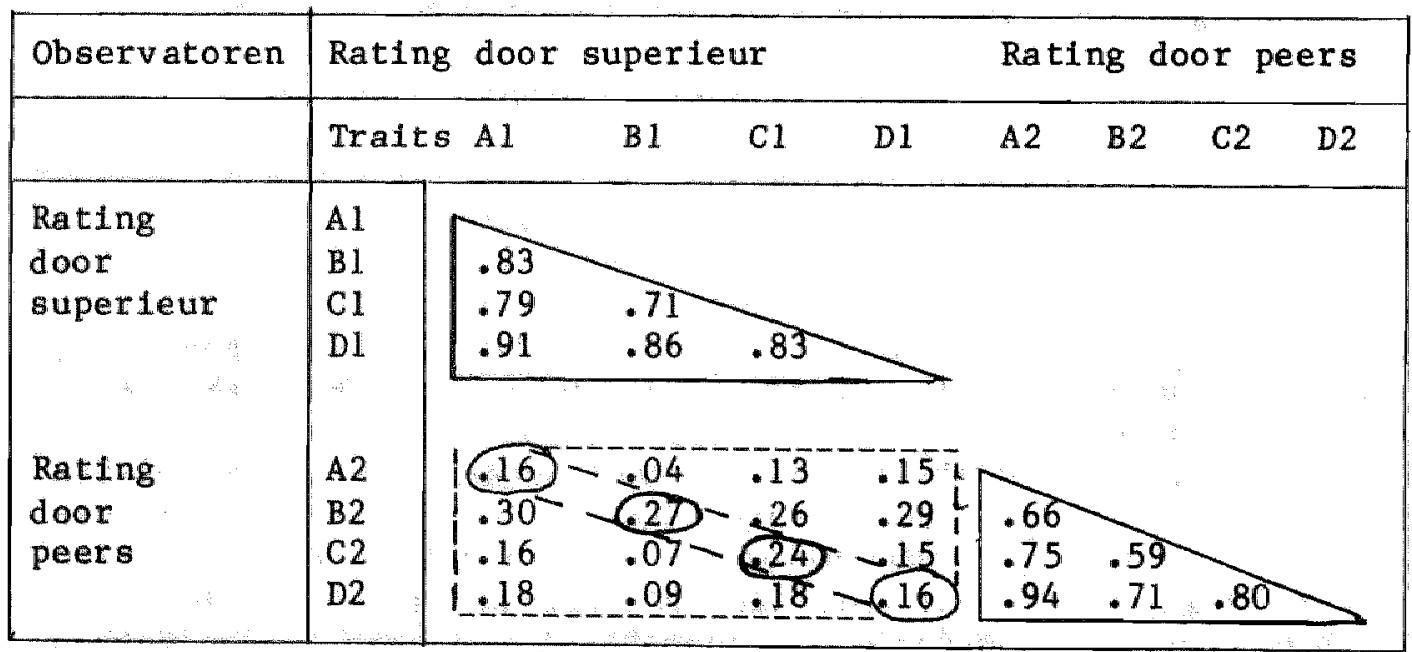

Bovenstaande tabel 3.1. betreft drie verschillende vormen van correlaties : 
1. Over dezelfde trait, bij verschillende observatoren (de omcirkelde correlaties),

2. Over verschillende traits binnen een observator (binnen de driehoeken gevormd door de ononderbroken 11 jnen),

3. Over verschillende traits én tussen de observatoren (binnen de driehoeken gevormd door de onderbroken lijnen).

Volgens Campbel1 en Fiske (1959) is er sprake van convergente validiteit wanneer de correlaties over dezelfde traits, tussen observatoren, significant verschillen van 0 (in ons voorbeeld groep 1).

Wil er sprake zijn van discriminante validiteit dan moet aan de volgende twee voorwaarden voldaan worden:

a. de correlaties, onder 1 genoemd, moeten groter zijn dan de correlaties tussen die trait en de andere traits, zowel binnen als tussen observatoren (bovengenoemd onder 2 en 3 ),

b. het patroon van interrelaties tussen de observatoren moet ge$11 j k$ zijn aan dat patroon binnen een observator.

In de geciteerde voorbeeldtabel wordt noch voldaan aan de eisen voor convergente validitelt, noch aan de elsen voor discriminante validiteit. Wel zijn duidelijk de hoge intercorrelaties binnen een observator te constateren, volgens de auteurs duidend op een halo-effect.

De winst van deze benadering is het inzicht in het gegeven dat twee groepen over dezelfde aspecten een geheel ander oordeel hebben.

Ondat een MTMM-matrix, zeker als deze betrekking heeft op een groot aantal correlaties zeer bewerkelijk en weinig inzichtelifk 1s, ste1t Kavanagh e.a. (1971) dat, bif de interpretatie van een MTMM-matrix, naast de techniek van Campell en Fiske eveneens een variantie-analyse is aangewezen.

Bij de analyse van deze correlatie-matrix mag niet uit het oog verloren worden, dat ook een dergelijke analyse niet ultputtend is. Een hoge correlatie kan -zoals eerder gesteld- goed samengaan met een verschil in opvatting over de mate warin lets voorkomt. Dit laatste is met name belangrijk indien aan dergelijke correlaties beleidsactiviteiten worden ontleend, aangezien niet zonder meer inzicht is gegarandeerd of bepalde arbeldsomstandigheden meer hinderen dan verondersteld wordt, dan wel of dat het beoordelingssysteem in de prakt1jk niet of anders wordt gehanteerd dan bekend is. 
In d1t hoofdstuk zifn de twee verschillende vormen van discrepantie, als algeheel organisatlekenmerk en als verschil in beoordeling per item, beschreven. Tevens zijn mogelljke oorzaken voor belde vormen van discrepantie aangegeven evenals de manier, waarop deze discrepanties geanalyseerd zullen gaan worden. In de volgende hoofdstukken zal aangegeven worden hoe de veronderstelde samenhang is tussen de algehele discrepantie in een organisatie en andere organisatiekenmerken (hoofdstuk 4), gevolgd door een statistische analyse van deze samenhang (hoofdstuk 5). In de hoofdstukken 6 en 7 zullen tenslotte de discrepanties per item geanal yseerd worden. 
HOOFDSTUK 4. ORGANISATIEKENMERKEN EN DE DISCREPANTIEVARIABELEN: Beschrijuing van de variabelen en de veronderstel11ngen.

4.1. Inlelding

De in hoofdstuk 2 beschreven interviews zijn verricht met behulp van voorgestructureerde vragenlijsten. Deze interviews leverden een groot informatiebestand op. Elk interview bestond uit een honderdtal vragen. In 'Werk en Ziekte' (Nijhuis en Soeters, 1982) $z i j n$ op basis van deze vragenlijsten een 34-tal variabelen gededuceerd ter operationalisering van evenzovele specifieke organisatiekenmerken. Als zodanig vormen zij een conglomeraat van zeer diverse organisatiekenmerken, zoals het gevoerde personeelsbeleid in de organisatie, de hiërarchie in de organisatie, de leeftijdsopbouw, de arbeidsomstandigheden, enz. De keuze en de constructie $v$ an de variabelen heeft platsgevonden op basis van eerder onderzoek naar de relatie tussen zlekteverzuim en arbeidsongeschiktheid enerzijds en organisatiekenmerken anderzijds. Dit heeft ertoe geleid dat de 34 geconstrueerde variabelen bestaan uit de belangrijkste, in de literatuur genoemde, organisatiekenmerken. Deze varlabelen zijn soms anders benoemd en veelal anders gemeten dan in de bestaande literatuur. Nadat op theoretische gronden de variabelen benoemd waren, zijn deze door middel van de items van de vragenlijsten verder ingevuld en vormgegeven. Het aantal 1tems per variabele viel wisselend uilt variërend van 1 (bijvoorbeeld betreffende de variabele: sector, waartoe de arbeidsorgantsatle behoort) tot 15 (bijwoorbeeld de variabele: voorkomen van materiëe1 bezwarende arbeidsomstandigheden). De volgende stap bij de constructie van de variabelen is geweest of deze theoretische indeling op face-value ook statistisch houdbaar bleek te $21 j n$. Daartoe is over de variabelen, die uit meerdere items bestonden, de betrouwbaarheidscoëfficiënt berekend (met behulp van het SPSS-program, zie daarvoor Hull en Nie, 1979).

Op basis van de 34 variabelen, die op deze manier geconstrueerd zijn (bijlage 3), zijn ten behoeve van de statistische discrepantie-analyse een aantal variabelen geselecteerd, die, althans theoret 1 sch, relevantie hebben voor de analyse van de discrepantievariabelen, met andere woorden in princlpe kunnen blfdragen tot beantwoording van vragen naar de oorzaken van discrepantles in arbeidsorganisaties. Deze varlabelen zijn voorzover mogelijk, berekend voor die groep van het personeel (direct-uitvoerend, 
mannelijk personeel) waarover ook de discrepantievarlabelen en de verzuimgegevens (zle hoofdstuk 5) berekend zijn. De onderlinge correlaties tussen deze variabelen zijn weergegeven in bijlage 4 . In paragraaf 4.2 . wordt een verantwoording van de keuze van de organisatievariabelen gegeven.

Vervolgens zal in paragraaf 4.3. een korte beschrijving gegeven worden van de 15 geselecteerde organisatievariabelen (voor een uitvoerige beschrijving zie: Nijhuis en Soeters, 1982).

In paragraaf 4.4 . van dit hoofdstuk zullen tenslotte de hypothesen geformuleerd worden ten aanzien van de relaties tussen de discrepantievariabelen en de organisatievariabelen.

4.2. Verantwoording van de keuze der varlabelen

Met de keuze van de varlabelen is een zo breed mogelijk scala van kenmerken van de organtsatie en van het personeelsbestand beoogd (z1e tabe1 4.1).

Ter typering van algemene organlsatlekenmerken zijn daartoe de volgende variabelen geselecteerd:

1. de aard van het arbeidsproces,

2. de organisatieomvang,

3. de autonomie in de bedrijfsvoering,

4. de hiërarchie in de organisatie.

Daarnaast zijn variabelen gekozen, die bepalend zijn voor de plaats van en de relatie tussen de verschillende beoordelaars in de organisatie.

Als variabelen, die inzlcht geven in de aard van het personeelsbest and:

5. het percentage 55-64 Jarige werknemers,

6. de mate waarin het personeel afkomstig is uit meer of minder verstedelijkte gebieden.

7. de werkgelegenheidssituatie.

Eveneens worden organisaties gekenmerkt door:

8. de aanwezigheld van de afdeling personeelszaken en de aanwezlgheld van interne overlegstructuren, gemeten middels:

9. de organisatie van de personeelsvertegenwoordiging en

10. het functioneren van het werkoverleg.

Bovendien $z 1 j n$ een aantal varlabelen geselecteerd ter typering van de technologische ontwikkeling binnen de organisatie: 
11. voorkomen van werkstructurering en

12. verandering in taken.

Ter typering van het personeelsbeleid van de organisatie is gekozen voor:

13. verzekeringswijze van de organisatie tegen kosten veroorzaakt door ziekteverzuim,

14. de mate van verstoring van het productieproces ten gevolge van ziekteverzulm en arbeidsongeschiktheld,

15. de mate van beleid gericht op aanpassing van werkzaambeden aan ziekte of handicap van de werknemers.

Bovendien $z i j n$ de variabelen 'hinder van materiële arbeidsomstandigheden' (16A) en 'hinder van immaterlële arbeldsomstandigheden' (16B) toegevoegd, daar deze waar nodig (zie: 5.1.3.) in de analyses worden betrokken.

Een aantal variabelen zijn specifiek geconstrueerd voor de personeelscategorle ten aanzien waarvan de analyses zijn uitgevoerd, namelijk voor het direct-uitvoerend, mannelijk personeel. Dit is gebeurd voor de variabelen $5,6,7,10,11,13,14,16 \mathrm{~A}$ en $16 \mathrm{~B}$. Deze variabelen $z i j n$ geselecteerd omdat zij een neerslag vormen van de algemene aspecten van de organisatie. De variabelen die niet in een analyse zijn meegenomen, zijn veelal de variabelen die aan de hier geselecteerde variabelen iets toevoegen, of daaraan sterk gerelateerd zijn, bijvoorbeeld:

- beleid gericht op opleiding en omscholing en een belonings- en beoordelingsbeleld geven informatie over de aard van het personeelsbeleid,

- gemiddelde leeftijd en diensttijd zijn gerelateerd aan percentage 55-64 jaren,

- sector en opleidingsniveau zijn gerelateerd aan de aard van het productiesysteem.

In tabel 4.1. zijn de statistische kenmerken van de geselecteerde variabelen weergegeven (voor een meer uitvoerige beschrijving zie: Nijhuls en Soeters, 1982). 
Tabe1 4.1. Overzicht van enkele statistische kenmerken van de onafhankelljke variabelen ten aanzien van de discrepantle-analyses.

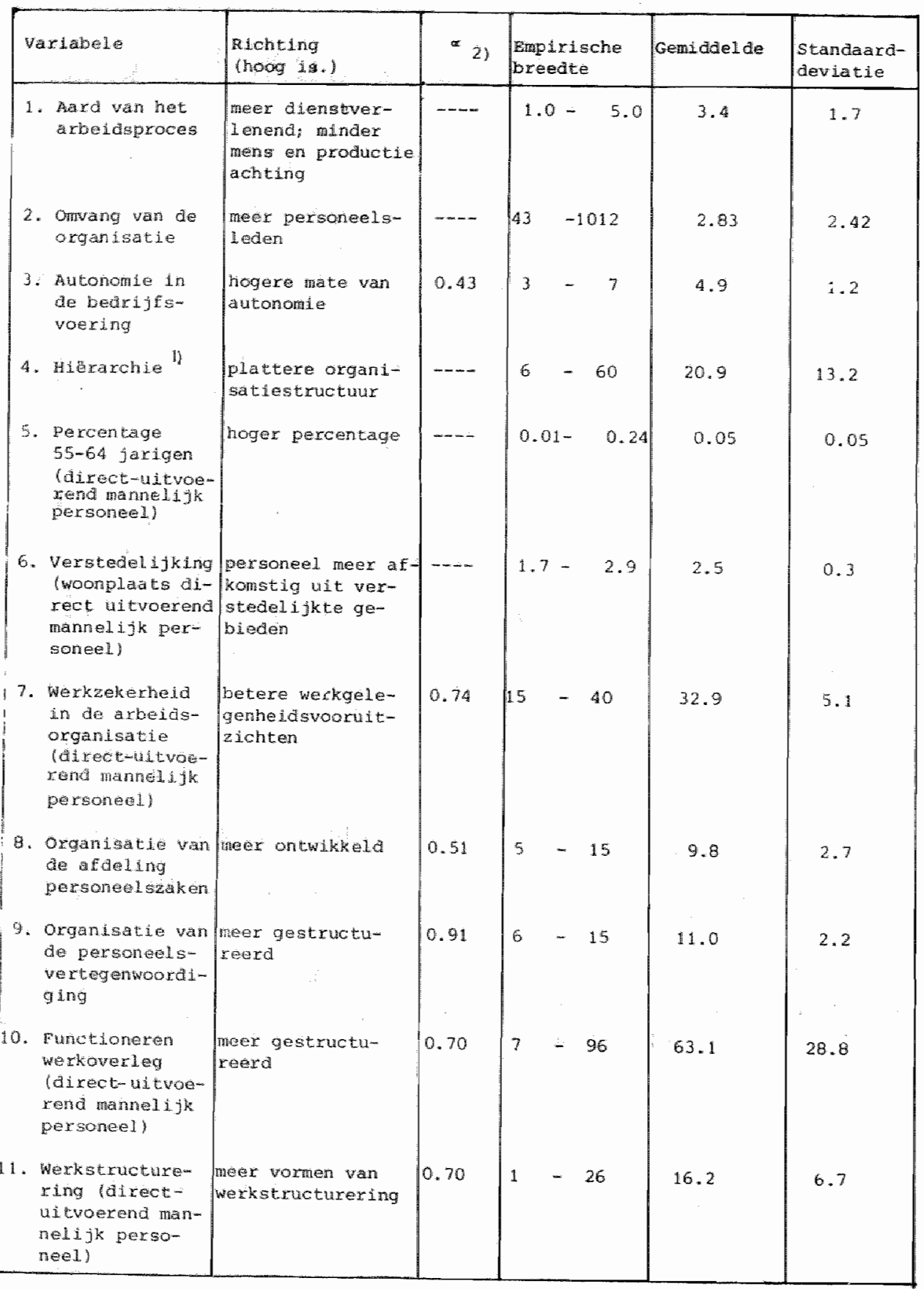


vervolg tabel 4.3.

\begin{tabular}{|c|c|c|c|c|c|c|c|}
\hline $\begin{array}{l}\text { 12. Verandering in } \\
\text { taken forect- } \\
\text { uitwoenend } \\
\text { manneliyk per- } \\
\text { sonem }\end{array}$ & meer vezandering & 0.74 & 5 & - & 37 & 28.1 & 6.0 \\
\hline $\begin{array}{l}\text { 13. Verzekerings- } \\
\text { wije van de } \\
\text { organisatie }\end{array}$ & $\begin{array}{l}\text { laag financieel } \\
\text { risico voor de } \\
\text { organisatie" }\end{array}$ & --- & 15 & - & 40 & 2.9 & 0.9 \\
\hline $\begin{array}{l}\text { 14. Verstoring } \\
\text { t.g.v. ziekte- } \\
\text { verzulim en ar- } \\
\text { beidsongeschikt- } \\
\text { neid ldirect- } \\
\text { uitvoerend man- } \\
\text { nelijk perso- } \\
\text { neel) }\end{array}$ & meer werstoring & 0.81 & 9 & - & 53 & 34.5 & 7.9 \\
\hline $\begin{array}{l}\text { 15. Aanpassingsbe- } \\
\text { leid }\end{array}$ & $\begin{array}{l}\text { meer verzoeken } \\
\text { angepaste ar- } \\
\text { peid gehono- } \\
\text { reerd }\end{array}$ & $-m$ & 0 & - & 10 & 5.7 & 3.5 \\
\hline $\begin{array}{l}\text { 16. Hinder van } \\
\text { materiele ar- } \\
\text { beidsonstan- } \\
\text { digheder }\end{array}$ & meer minder $x$ & 0.90 & 16 & - & 47 & 32.9 & B. 1 \\
\hline $\begin{array}{l}16 \mathrm{~B} \text {. Flndex van } \\
\text { Lmateriale } \\
\text { arbeidsom- } \\
\text { standigliaden }\end{array}$ & meer hinat & .75 & 5 & - & 15 & 9.6 & 2.5 \\
\hline
\end{tabular}

$N=42$

1) $N=36$

2) $=51$ 
Zoals uit tabel 4.1. blijkt zijn de betrouwbarheidscoëfficiënten, waar deze berekend konden worden, in het algemeen goed te noemen. Deze betrouwbaarheidscoëfficiënt is berekend over de 51 organisaties uit het oorspronkelijk onderzoek.

Schematisch leveren deze variabelen, ingedeeld naar de eerder genoemde categorieën, het volgende beeld op ten aanzien van de indeling van de variabelen.

F1guur 4. Schematische weergave van de organisatievariabelen die van invloed kunnen $z i j n$ op de discrepantievariabelen.

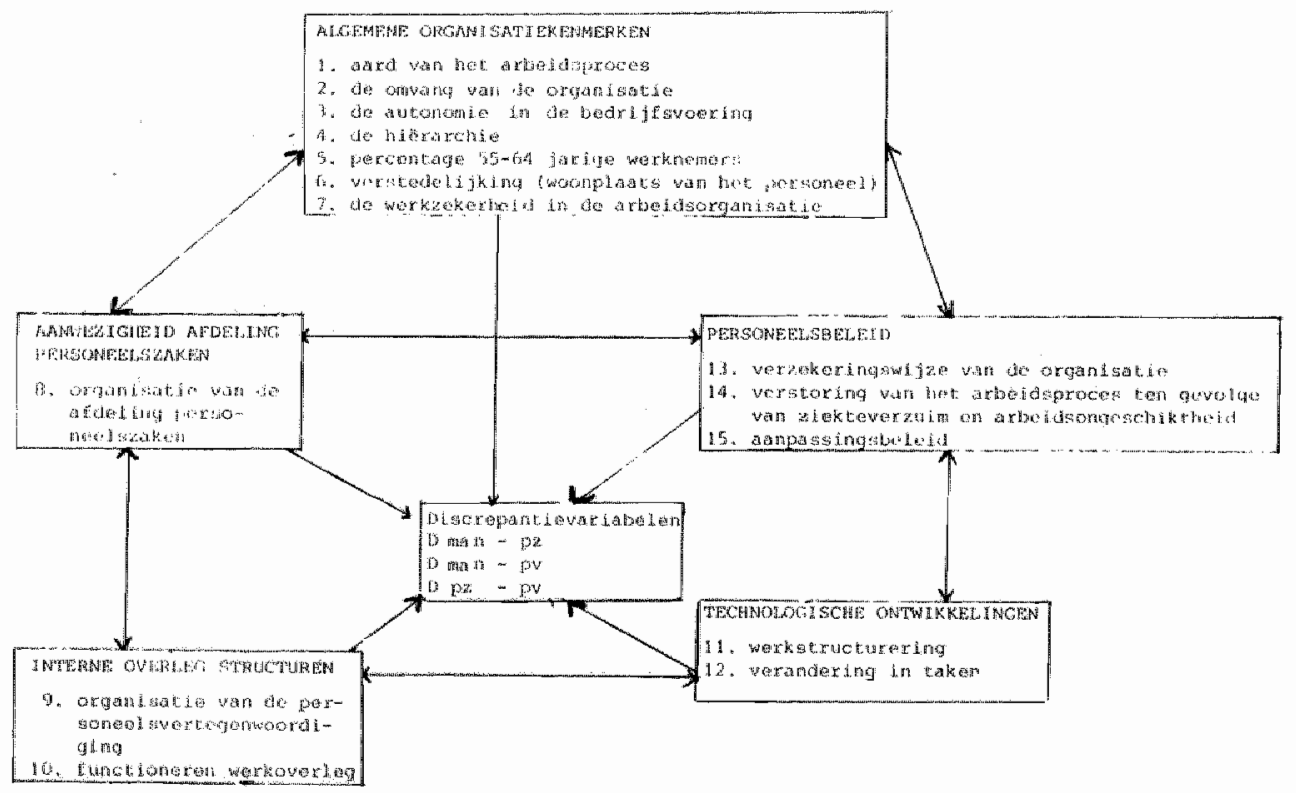


Gegeven de randvoorwaarden bepaald door de algemene organisatiekenmerken vormen deze in relatie met de vier overige onderscheiden categorieën (de aanwezigheid van een afdeling personeelszaken, de interne overlegstructuur, het personeelsbeleid en de technologische ontwikkelingen) elkaar beInv1oedende organisatiestructuurkenmerken, die voor een groot deel bepaald worden door randvoorwaarden, zoals deze binnen de organisatie bestaan (organisatiekenmerken). Verondersteld is dat elk van deze vijf categorieën een bijdrage levert aan het voorkomen of antstaan van de verschillende vormen $v$ an discrepantie.

De relatie tussen de arbeidsomstandlghedenvariabelen en de discrepantievariabelen $z a l$ afzonderlijk worden geanalyseerd.

In de analyse van de discrepantievariabelen zijn de arbeidsomstandighedenvariabelen slechts betrokken, voorzover een relatie tussen discrepantiescores en de arbeidsomstandighedenvarlabelen aanwezig is (zie: 5.1.3.). Dit vanwege de kans op contaminatie tussen de arbeidsomstandighedenvariabelen en de discrepantievariabelen, omdat deze laatsten voor een groot deel opgebouwd zijn uit beoordelingen betreffende de arbeidsomstandigheden. Bij de relatie tussen de verzuimindicatoren en de discrepantie zal eveneens het effect $v$ an de arbeidsomstandigheden in de beschouwing betrokken worden, vanwege het gebleken verband tussen deze arbeidsomstandigheden en de verzuimindicatoren (Nijhuls en Soeters, 1982).

\subsection{Beschrijuing van de variabelen}

\section{Variabele 1: De aard van het arbeldsproces}

Binnen de aan het onderzoek deelnemende arbeidsorganisaties $z 1 \mathrm{jn}$ zeer verschillende vormen van het arbeidsproces te onderscheiden. Naast zeer gespecialiseerde organisaties, die enkel stuks op bestelling produceren (groot metaal) zijn er organisaties, die in seriematige arbeid produceren. Bovendien zijn in het onderzoek eveneens zowel organisaties betrokken, die procesmatig produceren, als organisaties, die vooral dienstverlenend of verzorgend zijn. Deze verschillende bedriffsvormen zijn opgenomen in een reeks, variërend van massaproductie tot dienstverlenend en verzorgend. 
Variabele 2: Onvang van de organisatie

Zoals ook uit tabel 4.1. blijkt, is er in het onderzoeksbestand een nogal forse spreiding in omvang van de organisaties, namelijk van b1jna 43 tot meer dan 1012 werknemers.

\section{Variabele 3: Autonomie in de bedrijfsvoering}

Bij arbeidsorganisaties zijn verschillende rechtsvormen te onderscheiden. Deze verschillen in rechtsvormen kunnen van invloed zijn op de mate van autonomie in de bedrijfsvoering. De variabele 'autonomie in de bedrijfsvoering' is geconstrueerd met behulp van vragen ten aanzien van de tot stand koming van de vestigingsvorm, de mate van juridische zelfstandigheid in de beleidsvoering en het al of niet een familiebedrijf zijn.

\section{Varlabele 4: Hiërarchle}

De grootte, aard en autonomie van de organisatie zeggen op zich weinig over de hiërarchische structuurkenmerken. Er zifn grote organisaties met weinig hiërarchische niveau's en derhalve grote afdelingen of werkgroepen en kleinere organisaties met veel niveau's. De wijze waarop de organisatie gestructureerd is, heeft zijn invloed op het functioneren van de personeelsleden; vandaar dat de organisaties gevraagd is om informatie te geven over hun organlsatieopbouw. Op basis van deze gegevens is de hiërarchisering $v$ an de arbeidsorganisatie berekend met behulp $v$ an een door Philipsen (1969a) ontwikkelde hiërarchiemaat. Deze hiërarchiemat, hoger bij een minder stelle organisatieopbouw, is apart berekend voor de groep direct-ultvoerend, mannelijk personeel.

\section{Variabele 5: Percentage 55-64 Jarigen}

De leeftijdsopbouw en het personeelsverloop behoren tot de belangrijkste demografische kenmerken van het personeelsbestand. Door als variabele 'het percentage 55-64 jarigen' te kiezen, worden deze belde variabelen tot één enkele variabele teruggebracht.

De hoge intercorrelaties veroorloven deze ingreep (correlaties van deze variabele met: gemiddelde leeftijd $r=0.63$ en met diensttijd $r=0.50$. Bovendien is te verwachten dat de variabele "het percentage 55-64 jarigen' eerder een verband laat zien met discrepantie dan de gegevens betreffende leeftijdsopbouw en 
personeelsverloop afzonderlijk. Deze combinatie-variabele is berekend voor de groep direct-uitvoerend mannelijk personeel.

\section{Variabele 6: Verstedelijking}

Sommige organisaties zifn in kleinere gemeenten gevestigd en recruteren hun personeel uit plattelands-gebieden, andere $z 1 j n$ gevestigd in verstedelijkte gebieden en trekken hun werknemers zowel uit meer verstedelijkte, als uit meer plattelands-gebieden. Bekend is dat werknemers uit meer verstedelijkte gebieden gekenmerkt worden door een ander beroepsbeeld dan werknemers ult plattelands-gebieden (Phillpsen, 1969a). Bovendien bestaan er verschillen in culturele oriëntatie tussen deze beide groepen. Hierdoor kan het klimat in de arbeidsorganisatie verschillen al naar gelang het recruteringsgebied van het personeel. Vandaar dat deze variabele hier -berekend voor het direct-uitvoerend, manne$11 j k$ personeel- is opgenomen (Kruldenier, 1981 en 1983; Smulders e.a. 1983; Smulders, 1983; Nijhuis, 1983).

\section{Variabele 7: Werkzekerheid in organisaties}

Vaak wordt een relatie gelegd tussen het gedrag van individuen in organisaties en de werkgelegenheldsvooruitzichten ten aanzien van die organisatie. Ondat een bedreiging van de werkgelegenheld gepaard gat met een economisch slechtere situatie zal dit allicht leiden tot extra doorlichting van de organisatie door het management. Vandaar dat het aannemelijk is dat een relatie zal bestaan tussen de werkgelegenheidsvooruitzichten en de mate van kennis bij het management over verschillende organisatie-aspecten. De onderhavige variabele is geconstrueerd op basis van een aantal vragen die deels aan elk van de informanten gesteld zijn. Hierdoor werd informatie verkregen ten aanzien van de werkgelegenhelds-voorultzichten, ontslagen, afvloeilngen, reorganisaties e.d. De antwoorden op deze vragen zijn redelijk goed met elkaar in overeenstemming, hetgeen ook blijkt uit een betrouwbararheidscoëfficiënt van 0.74 . Deze varlabele is berekend voor het directuitvoerend, mannelijk personeel.

\section{Variabele 8: Organisatie van de afdeling personeelszaken}

Indien bij de discrepantie-analyse gekeken wordt naar de discrepantie tussen de beoordeling van het hoofd personeelszaken en die van de belde andere informanten zal het duidelijk zijn dat deze 
variabele niet in de analyses mag ontbreken.

De mate warin door de -aan het onderzoek deelnemende- organisaties de nadruk wordt gelegd op het personeelsbeleid is nogal divers. Relevant is in dit kader in hoeverre een zelfstandig en professioneel personeelsbeleid in de betreffende organisatie bestaat. Daartoe $z 1 j n$ onder andere de volgende aspecten gemeten:

- is er een aparte afdeling personeelszaken en is er dan een vastgelegde taakomschrijving?

- hebben de medewerkers op de betreffende afdeling een specifieke opleiding?

\section{Varlabele 9: Organlsatie van de personeelsvertegenwoordiging}

Voor de variabele 'organisatie van de personeelsvertegenwoordiging' geldt, wat betreft de noodzaak tot de opneming in de verwerving en verwerking in dit onderzoek, mutatis mutandis hetzelfde als voor de voorafgaande variabele. Binnen dit onderzoek bleken global gesproken een drietal verschillende overlegvormen te bestaan, door middel waarvan het personeel via geinstitutionaliseerde kanalen invloed kan uitoefenen op de organisatie of op het organisatiebeleid, namelijk:

- een vrijwillige personeelsvertegenwoordiging (bijvoorbeeld een bedrijfs- of bureauraad),

- een dienstcomissie of andere vormen van georganiseerd overleg,

- een ondernemingsraad.

Bif de opbouw van deze variabele is voorts verdisconteerd hoeveel werktijd personeelsleden mochten besteden aan het werk ten behoeve van deze organen, de vergaderfrequentie en de samenstelling van de oR. Deze vormen zijn geordend op basis van de formeel vastgelegde bevoegdheden, warbij eveneens de bevinding van Teulings (1981a) betrokken 1s, dat een personeelsvertegenwoordiging, die wordt voorgezeten door een werknemer, conform de Wet op de ondernemingsraden 1981, radicaler en meer tot confrontatle met het management genelgd zal zijn dan een personeelsvertegenwoordiging, waarbij dat niet het geval is.

\section{Varlabele 10: Functioneren werkoverleg}

Werkoverleg is een geregelde vorm van overleg tussen de chef en zijn medewerkers ten aanzien van zaken, die betrekking hebben op het werk en de werkomstandigheden. Werkoverleg wordt door velen gezien als een manier on de interne communicatie binnen de organisatie te vergroten en als middel om tot grotere arbeidssatis- 
factie en tot grotere participatie van de werknemers te komen (Koopman en Wierdsma, 1980). In het kader van de 'humanisering $v$ an de arbeidsprojecten" wordt werkoverleg als een positieve factor beschouwd. Als zodanig zou verondersteld kunnen worden dat werkoverleg relevant is voor de verklaring van aard en omvang van discrepanties in de arbeidsorganisatie.

Gemeten is vooral de mate waarin het werkoverleg een geinstitutionaliseerde vorm heeft gekregen (regelmaat, schriftelijk verslag, agenda e.d.). Aangezien blnnen de deelnemende organisaties op verschillende organisatieniveau"s geheel andere vormen van werkoverleg bleken te bestaan is deze variabele gericht berekend voor het direct-uitvoerend, mannelijk personeel.

\section{Variabele 11: Werkstructurering}

Werkstructurering kan omschreven worden als het streven om de werkorganisatie en het werk zoveel mogelijk aan te passen aan de wensen en de mogelijkheden van de werknemer (De Sitter, 1981). Werkstructurering gaat meestal gepaard met een uftbreiding en verrijking van taken. Door middel van werkstructurering kan de positie van de werknemer in de organisatie ten aanzien van $z \mathbb{1} f n$ werk verbeterd worden. Dit kan gebeuren in samenspraak met de betrokken werknemers of vertegenwoordigers ervan, maar ook onafhankelijk daarvan. In het eerste geval, waarbij sprake is van $\mathbb{1 n}-$ spraak in werkstructureringsprojecten of -activiteiten, wordt aangenomen dat het een meer gestructureerde vorm van werkstructurering is. Binnen de productiesector kan werkstructurering geheel andere vormen aannemen dan in andere sectoren $v a n$ de organisatie, vandaar dat ook deze variabele berekend is voor het direct-uitvoerend, mannelijk personeel.

\section{Variabele 12: Verandering in taken}

Binnen arbeldsorganisaties kunnen zich geheel verschillende soorten veranderingen in taken voordoen, bij reorganisaties of verlies van arbeidsplaatsen, maar ook bij nieuwe investeringen. Ook in de taken $v a n$ individuele werknemers kunnen verschuivingen plaatsvinden. Deze veranderingen kunnen een positieve ultwerking hebben op de aard van de werkzamheden (humanisering van de arbeid, invoering van werkstructurering), maar ook negatieve effecten (bijvoorbeeld: taakverzwaring, vergroting van de gebondenheld aan apparatuur of machines). Bovendien kunnen ontwikkelingen als automatisering bedreigend zijn ten aanzien van de arbeidsplaats- 
zekerheld. Voorts kunnen veel veranderingen in taken ook "de rust op de arbeldsplaats" verstoren. Gemeten is de mate warin zich voor het direct-uitvoerend, mannelijk personeel taakveranderingen hebben voorgedaan.

\section{Varlabele 13: Verzekeringswijze van de organisatle}

De verzekeringswijze van de organisatie tegen kosten veroorzaakt door arbeidsongeschiktheid van werknemers, kan een uitdrukking $z 1 j n$ van de manier waarop de organisatie met personeelsleden omgaat (zie: Smulders e.a., 1983). De veronderstelling, die aan deze vartabele ten grondslag $11 \mathrm{gt}$, is dat, naarmate een organisatle een groter financiëel risico heeft ten gevolge van arbeidsongeschiktheid, zij meer activitelten onderneemt om het aantal risicofactoren te verkleinen en het aantal bindingsaspecten aan de organisatie te vergroten.

Varlabele 14: Verstoring ten gevolge van ziekteverzuim en arbeldsongeschiktheld

Afwezlgheid wegens ziekte kan zowel storend $z i j n$ voor het productieproces als voor de werklust van de overblijvende collega's. Als lemand ziek wordt kunnen verschillende maatregelen genomen worden, zoals herverdeling van het werk, opdrachten tot overwerk, annuleren van opdrachten en bijplaatsing van andere werknemers. De mate warin ziekteverzuim drukt op de overige personeelsleden wordt mede beinvloed door de bezettingsgraad van het personeel: bij een lage bezettingsgraad zal verzuim tot extra activiteiten aanlelding geven (zle Vreeman, 1982).

Deze varlabele is eveneens berekend voor het direct-ultvoerend, mannelijk personeel.

\section{Varlabele 15: Aanpassingsbeleld}

De aanwezigheid van een ziekte of handicap betekent niet altijd, dat de werknemer niet in staat is om enige vorm van arbeid te verrichten. Arbeidsongeschiktheid is een begrip dat altijd bekeken moet worden in relatie tot de op de werkplek geldende omstandigheden en elsen. Naarmate de organisatie meer beleid richt op het tijdelijk of definitief aanpassen van de met het werk samenhangende omstandigheden, zal de (noodzaak om) kennis (te nemen) van de eigen organisatie groter moeten zijn. Vandaar dat de varlabele betreffende de mate warin de arbeidsorganisatie in 
staat is om verzoeken tot aangepast werk te honoreren in de analyses van de discrepanties 1 s opgenomen.

\section{Variabele 16: Arbeldsomstandigheden}

Gemeten is voor welk deel van het direct-uitvoerend, mannelijk personeel hinderlijke arbeidsomstandigheden aanwezig zijn. Het betreft daarbij zowel de materiële, als de immaterièle bezwaar1ijke arbeidsomstandigheden.

De beoordeling van de arbeidsomstandigheden is bij alle respondenten gemeten en per respondent afzonderlijk berekend. In dit kader is gekozen voor een variabele (16A), die de mate van hinder $v$ an de materiële arbeidsomstandigheden weergeeft en een variabele (16B), die een neerslag vormt van de mate van hinder van de immateriële arbeidsomstandigheden.

De materiële arbeidsomstandigheden $21 j \mathrm{n}$ berekend op basis $v$ an de mate waarin het personeel hinder ondervindt van de volgende omstandigheden: trilling, ongevallen rislco, koude/warmte, temperatuurwisselingen, stof, lawal, vull, vocht/tocht, stank, gas/ damp, straling, onbekende stoffen, lichamelijk zwaar werk, slechte lichaamshouding en giftige stoffen.

De immateriële arbeidsomstandigheden zijn berekend op basis van de mate, waarin het personeel hinder ondervindt van de volgende omstandigheden: geestelijk zwaar werk, te weinig vrijheid om het werk zelf in te delen, te hoog arbeidstempo, slechte werksfeer en onduidelijke taakinhoud. De analyses waarin deze beide variabelen betrokken worden gat uit van de gemiddelde beoordeling van de drie categorieën beoordelaars.

4.4. Hypothesen betreffende discrepanties in de arbeidsorgantsatie

Ondat soortgelijk onderzoek grotendeels ontbreekt zullen in deze paragraaf slechts die veronderstellingen beschreven worden, die logisch voortvloeien of verwacht kunnen worden op basis van de 1iteratuur genoemd in hoofdstuk 3. Bij de formulering van de hypothesen zullen we de volgorde aanhouden van de variabelen genoemd in 4.3., waarbij die variabelen worden overgeslagen, waarover geen eenduldige verwachtingen bestaan. Zo is bijvoorbeeld wel bekend dat leeftijd en de soclaal culturele achtergrond van invloed zijn op de beleving en beoordeling van taakkenmerken (zie hoofdstuk 3). Niet voorspelbaar is echter of deze varlabelen de 
mate van discrepantie, hetzij positief, hetzij negatief, zullen belinvloeden.

\section{Vartabele 1: Aard van het arbeldsproces}

Ten aanzien van het onderscheld tussen een meer technologisch en een meer dienstverlenend beleid is het aannemelijk dat de discrepantie tussen het managenent en de overige twee beoordelaars geringer is naarmate het organisatiesysteem meer technologisch/machine-gerlcht is. Bij de beslissing over investeringen wordt de kennis over de directe productie namelijk noodzakelijker naarmate deze besllssingen het productiesysteem directer raken.

\section{Vartabele 4: H1ërarchie}

Onderscheid is gemaakt tussen organisaties, met een zogenaamde plattere organisatlestructuur en organlsaties met een stellere structuur. Nifhuis en Soeters (1982) hebben beredeneerd dat een hiërachisch, steilere, meer gelaagde organisatieopbouw de communicatie bevordert: een dergelijke structuur verhoogt de kans op het inzicht van chefs in de te verrichten werkzaamheden en eventuele problemen ten aanzien van de werkultvoering kunnen eerder aan het daglicht treden. Een platte organisatiestructuur $z a l$ echter veelal samengaan met een relatief eenvoudig productieproces (Veen, 1980B). Vandaar dat verwacht wordt dat een platte organisatiestructuur zal leiden tot lagere discrepanties.

\section{Variabele 7: Werkzekerheid in de organisatie}

Naarmate de werkzekerheid in een organisatie slechter is, zal blinnen de organisatie meer aandacht geschonken worden aan mogelifkheden tot rendementsverbetering, efflciency bevorderende reorganisatles en dergelijke. Deze opgaven zullen zowel 11ggen op het terrein $v$ an het management als op het terrein van personeelszaken. Aandacht voor deze aspecten van het organlsatiebeleld zal ertoe Jelden, dat de kennls en inzlcht $v$ an het management en personeelszaken in de organisatiestructuur vergroot wordt. Vandaar dat verondersteld wordt, dat de discrepantie tussen deze beide groepen enerzijds en de personeelsvertegenwoordiging anderzijds groter is, naarmate de werkzekerheid in een arbeidsorganisatie groter is. 
Variabele 8: De organisatie van de afdeling personeelszaken

Naarmate de organisatle van de afdeling personeelszaken meer verzelfstandigd is, $z a l$ de communicatie en daarmee de informatieafstand tussen management en personeelszaken vergroot worden en dientengevolge ook de discrepantie tussen de beoordelingen van deze beide respondenten. De discrepantie met de beoordeling $v a n$ de personeelsvertegenwoordiging $\mathrm{zal}$ echter afnemen.

\section{Variabele 9: De organisatle van de personeelsvertegenwoordiging}

Naarmate de personeelsvertegenwoordiging actiever en meer gestructureerd zal zijn, zal de discrepantie afnemen. Door intensievere contacten over verschillende onderwerpen, die de organisatie betreffen, zal er namelijk, gegeven een dergelijke infrastructuur binnen de organisatie, een grotere mate van uitwisseling van informatie plats hebben. Deze invloed zal vooral betrekking hebben op de discrepantie tussen management en personeelsvertegenwoordiging (Dman-pv) en op de discrepantie tussen hoofd personeelszaken en personeelsvertegenwoordiging (Dpz-pv).

\section{Variabele 10: Werkoverleg}

Analoog aan de redenering over een meex gestructureerde personeelsvertegenwoordiging gelden de aldaar geformuleerde hypothesen, ook voor een beter georganiseerd werkoverleg. Een dergelijk werkoverleg maakt het mogelijk om de informatie-afstand tussen personeel enerzijds en management en personeelszaken anderzijds te verkleinen.

\section{Variabele 11: Werkstructurering}

Werkstructurering eist de nodige ingrepen in de structuur van de productie, vandaar de veronderstelling dat veel activiteiten ten aanzien van werkstructurering zullen leiden tot een geringere Dman-pv •

\section{Variabele 12: Verandering van taken}

Voor deze variabele geldt hetzelfde als voor 'werkstructurering'. Veel activiteiten ten aanzien $v$ an verandering van taken eisen een meer directe bemoelenis met de productie en lelden daarmee eveneens tot een lagere Dman-pv. 
Var1abele 13: Verzeker1ngswifze van de organisatie

Deze variabele is genomen als een indicator voor het personeelsbeleid in de organlsatie. Naarmate het elgen risico groter is, zullen meer pogingen gedaan worden om de oorzaken van verzulim op te sporen. Vandaar de veronderstelling dat een groter elgen risico in de verzekeringswijze van de organisatie zal leiden tot een 1 agere discrepantle tussen personeelszaken en personeelsvertegenwoordiging. Bovendien $z a l$ het management vanwege rendementsoverwegingen ook betrokken willen zijn bij de activiteiten van personeelszaken, om de kosten verbonden aan het eigen risico terug te dringen. Derhalve dient een groter eigen risico dus eveneens te leiden tot een kleinere Dman-pz.

Variabele 14: Verstoring ten gevolge van ziekteverzuim en arbeidsongeschiktheid

Naarmate de verstoring van het arbeldsproces groter is, zal zowel personeelszaken als het management sterker betrokken $z 1 j n$ bij de organisatie van het productieproces. Bovendien zal het management op de hoogte zijn van activitelten van personeelszaken inzake de oplossing van problemen, zoals deze kunnen ontstaan ten gevolge van zlekteverzulm. Een grote mate van verstoring levert dan ook een sterke noodzaak op om zich optimaal over het productieproces en de personeelsbezetting te informeren. Vandaar $d a n$ ook $d$ at naarmate deze verstoring groter is alle vormen van discrepantie kleiner zullen zijn.

\section{Vartabele 15: Aanpassingsbeleid}

Bij het aanpassingsbeleid gat het on activiteiten $v$ an personeelszaken, gerlcht op het vinden en creëren van aanpassingen van werkzaamheden aan ziekte of handicap van een of enkele werknemers. Een meer intensief beleid op dit gebied zal leiden tot een betere kennls bij personeelszaken over de opvattingen die bij het personeel leven en daarmee tot een geringere Dpz-pv.

Ondat een dergelijk beleld veelal eveneens vraagt om zowel sociale, als technische, productie gerichte matregelen zal deze factor ook leiden tot een intensiever overleg tussen personeelszaken en management over mogel1jkheden van aanpassingen en daarmee tot een geringere Dman-pz. 
Ten aanzien van de relatie tussen de discrepantievariabele en arbeidsomstandigheden zijn geen hypothesen geformuleerd, omdat deze niet direct in de analyse-opzet betrokken worden.

Evenmin zullen veronderstelingen gegeven worden ten aanzien $v a n$ de mogelijke samenhang tussen de discrepantievarliabelen en de verzuimfrequentie, verzuimduur en het aantal WAO/IP-toetredingen. In het komende hoofdstuk zal de over-all discrepantievariabelen geanalyseerd worden met behulp van de in dit hoofdstuk beschreven variabelen. Bovendien zal in dat hoofdstuk ook de relatie tussen deze discrepantievariabelen en de verschillende verzuimindicatoren onderzocht worden. 
$-82-$ 
HOOFDSTUK 5: DISCREPANTIE BINNEN DE WERKORGANISATIE

5.1. De discrepantievariabelen

5.1.1. Statistische kenmerken

Zoals in hoofdstuk 4 reeds beschreven, zijn per arbeldsorganisatie een drietal discrepantiescores berekend, te weten:

- de discrepantie tussen de beoordelingen van het management (hoofd van de productie-afdeling) en die van het hoofd personeelszaken (Dman-pz);

- de discrepantie tussen de beoordelingen van het management (hoofd van de productle-afdelingen) en die van de personeelsvertegenwoordiging ( Dman-pv);

- de discrepantie tussen de beoordelingen van het hoofd personeelszaken en die $v a n$ de personeelsvertegenwoordiging (Dpz-pv).

In tabel 5.1. worden de statistische kenmerken gegeven van deze drie discrepantievariabelen.

Tabel 5.1. Statistische kenmerken van de discrepantievariabelen.

\begin{tabular}{|c|c|c|c|c|c|}
\hline & $\begin{array}{l}\text { aantal } \\
\text { items }\end{array}$ & min. $\max$ & $\begin{array}{l}\text { gemid. } \\
\qquad\end{array}$ & $\begin{array}{l}\text { Stand. } \\
\text { dev. }\end{array}$ & $\begin{array}{l}\text { betrouwbaar- } \\
\text { heids- } \\
\text { coëfficlënt } \\
\text { (a) }\end{array}$ \\
\hline $\begin{array}{l}\text { Dman-pz } \\
\text { Dman-pv } \\
\text { Dpz-pv }\end{array}$ & $\begin{array}{l}24 \\
35 \\
49\end{array}$ & $\begin{array}{rr}99.61 & 100.72 \\
99.65 & 100.82 \\
99.66 & -100.55\end{array}$ & 100.00 & $\begin{array}{l}0.28 \\
0.25 \\
0.22\end{array}$ & $\begin{array}{l}0.49 \\
0.57 \\
0.59\end{array}$ \\
\hline
\end{tabular}

Zoals eerder aangegeven nemen door de statistische bewerking de discrepantievariabelen waarden aan die rond de honderd 1iggen met berekeningstechnisch een noodzakelijk gemiddelde van 100. De range van de waarden bij de discrepantievariabele tussen het hoofd personeelszaken en de personeelsvertegenwoordiging blijkt kleiner dan bij de overige twee variabelen. Blijkbaar is de discrepantie tussen deze belde groepen minder groot, terwlj1 ook de standaard deviatie bij deze variabele het kleinst is. De discrepantiescores met het management $z i j n$ in alle gevallen groter, waarbij de range 
van de discrepantie tussen management en personeelszaken overigens klelner $1 \mathrm{~s}$ dan bij de discrepantie tussen management en personeelsvertegenwoordiging. Dit duidt erop dat naarmate de positles van de beoordelaars in de organisatie dichter bij elkaar liggen de discrepantierange geringer is.

Deze discrepantievarlabelen behoeven niet noodzakelijkerwijs intern consistent te zijn, daar een discrepantie op het ene gebied niet noodzakelijkerwijs discrepanties op andere gebieden inhoudt. Toch blifken de drie discrepantievariabelen een voldoende $\alpha$-waarde te bezitten, $(>.40$; Nunally, 1967), hetgeen een voldoende aanwjzing is voor een interne consistentie. Arbeldsorganisaties blijken zich te kenmerken door een grotere of kleinere discrepantie, zodat een hoge discrepantie op het ene item samengaat met een hoge discrepantie op een ander item.

5.1.2. De onderlinge relaties tussen de discrepantievariabelen

In de vorige hoofdstukken zijn wel hypothesen geformuleerd over de mogelijke oorzaken van discrepantie op zich, echter niet ten aanzlen van de samenhang tussen de discrepanties onderling. Toch zal hier allereerst gekeken worden naar de samenhang tussen discrepanties. De samenhang tussen de discrepantievarlabelen is op een tweetal manleren geanalyseerd; naast de Pearson-correlatie coëfficiënt is ook de samenhang tussen twee discrepantievariabelen berekend onder constanthouding van het effect van de derde. Deze correlaties zijn weergegeven in tabel 5.2 .

Tabe1 5.2. Gepartlaliseerde en ongepartialiseerde correlaties tussen de drie discrepantievariabelen.

\begin{tabular}{|lccc|}
\hline $\begin{array}{l}\text { Discrepant } \\
\text { variabele }\end{array}$ & Dman-pz & Dman-pv & Dpz-pv \\
\hline $\begin{array}{l}\text { Dman-pz } \\
\text { Dman-pv }\end{array}$ & $(-01)$ & -.04 & -.04 \\
Dpz-pv & $(-.03)$ & $(.27 * *)$ & $-25 *$ \\
\hline
\end{tabular}

$\mathrm{N}=42$

(...): ongepartialiseerde correlaties

** : $0.01<\mathrm{p} \leqslant 0.05$

* $\quad: \quad 0.05<p \leqslant 0.10$ 
De Dman-pz blijkt niet gerelateerd te zijn aan Dman-pv en de Dpz-pv; slechts tussen de Dman-pv en de Dpz-pv blijkt duidelijk samenhang te bestaan. Naarmate de discrepantie tussen de beoordelingen van het management en de personeelsvertegenwoordiging groter is, is ook de discrepantie tussen de beoordellngen van het hoofd personeelszaken en de personeelsvertegenwoordiger groter. De eerste indruk is dat arbeidsorganisaties zich kenmerken door de mate van verschil tussen beoordelingen van organisatiekenmerken door het uitvoerend personeel en door de verschillende 'staf" afdelingen, zonder dat dit echter impliceert dat de beoordelingen van deze beide 'staf' afdelingen aan elkaar gerelateerd zijn. Dit duidt erop dat organisaties zich kenmerken door de mate van discrepantie tussen leiding en werknemers.

5.1.3. De relaties tussen de discrepantievariabelen en de arbeidsomst andighedenvariabelen

Op de discrepantie ten aanzien van de arbeldsomstandigheden zal uitvoerig ingegaan worden in hoofdstuk 7. Ondat de arbeldsomstandighedenvarliabelen een belangrijke bijdrage hebben geleverd aan de uiteindelijk gecreëerde discrepantlescores moeten de relaties tussen deze discrepantievariabelen en de arbeidsomstandighedenvartabele geanalyseerd worden. Daartoe zijn de correlaties berekend tussen discrepantiescores en de beoordelingen van de arbeidsomstandigheden door management (man.), personeelszaken $\left(\mathrm{p} \cdot \mathrm{z}_{.}\right)$en leden personeelsvertegenwoordiging (p.v.).

Tabe1 5.3. Correlaties tussen de discrepantievariabelen en de arbeld somstandighedenvariabelen.

\begin{tabular}{|c|c|c|c|c|c|c|}
\hline & \multicolumn{3}{|c|}{$\begin{array}{l}\text { materiëel hinderlijke } \\
\text { arbeidsomstand } 1 \text { gheden }\end{array}$} & \multicolumn{3}{|c|}{$\begin{array}{l}\text { Immateriëel hinderlijke } \\
\text { arbeidsomstandigheden }\end{array}$} \\
\hline & $\operatorname{man}$ & p.z. & P.V. & $\operatorname{man}$ & $\mathrm{p} \cdot \mathrm{z}$. & $\mathrm{p} \cdot \mathrm{v}$. \\
\hline Dman $-p z$ & $.35 * * *$ & $.60 * * *$ & $.33 * *$ & -.07 & .19 & -.01 \\
\hline Dman-pv & .08 & $.29 * *$ & $.55 * * *$ & $-.45 * * *$ & $-.22 \star$ & .16 \\
\hline $\mathrm{Dp} z-\mathrm{pv}$ & -.01 & -.04 & .12 & .04 & .03 & .19 \\
\hline
\end{tabular}

$\mathrm{N}=42$

$* * *: \mathrm{p} \leqslant 0.01$

** $: 0.01<p \leqslant 0.05$

* $\quad: 0.05<\mathrm{p} \leqslant 0.10$ 
De variabele "hinder van materiele arbeldsomstandigheden" (volgens de drie beoordelaars) blijkt hoog te correleren met de belde discrepantiematen betreffende het management. Naarmate de arbeldsomstandigheden materlëel meer hinder veroorzaken blijken deze discrepanties geringer. Dit wettigt de veronderstelling, dat naarmate de arbeldsomstandigheden objectief slechter zijn, dit duidelijker constateerbaar 18 en daardoor minder ruimte biedt voor afwljkende oordelen ( $p l$ afond-effect).

Deze relatie 18 echter niet gevonden ten aanzien van de discrepantie tussen het hoofd personeelszaken en de personeelsvertegenwoordiging. De variabele 'hinder van materiële arbeidsomstanidgheden' (volgens het management) blijkt slechts samen te gaan met de Dman-pz, hetgeen betekent dat meer gepercipleerde hinder ten gevolge van slechte arbeldsomstandigheden samenhangt met een kleinere discrepantie. Verondersteld kan worden dat (evident) slechte arbeldsomstandigheden minder discrepanties toestaan. Indirect wordt de bovenstaande verklaring bevestigd door een tegengestelde relatie tussen de belde 'hinder van immateriële arbeldsomstand 1 gheden'-varlabelen (volgens management en personeelszaken) en de Dman-pv. Deze Immaterlële arbeldsomstandigheden zijn minder goed waarneembaar en staan daardoor grotere discrepantle toe. In tegenstelling tot de relaties bij de immateriële arbeidsomstandigheden geldt dat de immateriële arbeidsomstandigheden als hinderlijker ervaren worden naarmate de Dman-pv groter is.

De gevonden verbanden laten in elk geval zien dat de discrepantiematen niet gelijk zijn aan de arbeidsomstandighedenvariabelen. Daar sterke verbanden gesignaleerd worden tussen de Dman-pz en de 'hinder van materfële arbeldsomstandigheden' en tussen de Dman-pv en diezelfde varlabele en tevens met de variabele 'hinder van immateriële arbeldsomstandigheden' $z a l$ blj de analyse van de Dman-pz ook een gemiddelde score 'hinder van materiële arbeldsomstand Igheden" (gemiddelde van de drie metingen per organisatie) en bij de analyse $v$ an de Dnan-pv zowel een gemiddelde 'hinder van materiële als van Immateriële arbeldsomstandigheden' meegenomen worden.

5.2. De analyse van de discrepantiescores

5.2.1. Inleiding

Voor de interpretatie van de resultaten $v a n$ de analyses van de 
overall-discrepantiemat aan de orde komen dienen eerst een tweetal prealabele vragen beantwoord te worden:

a. Wat meet deze overall-discrepantiemaat?

b. In hoeverre is er sprake van contaminatie, gegeven het felt dat deze discrepantiemaat op dezelfde vragenlijsten gebaseerd zijn als de organisatiekenmerken?

ad. a.

Zoals reeds eerder gesteld (3.3.) zijn de gehanteerde discrepantiematen kwantitatieve afstandsmaten tussen de oordelen van categorieën beoordelaars met beslissings- of invloedsmacht. Ten aanzien van de productieafdeling betreft het daarbij de discrepantie tussen management en personeelsvertegenwoordiging (Dman-pv), ten aanzien van het personeelsbeleid de discrepantie tussen personeelszaken en personeelsvertegenwoordiging (Dpz-pv) en ten aanzien van de onderlinge stafafdelingen over het werk in de productie de discrepantie tussen management en personeelszaken (Dman$\mathrm{pz}$ ).

De hoogte $v$ an de discrepantievariabelen kan daardoor in principe beInvloed worden door een drietal factoren: ruis, over de organisatie heen bestaande positie-effecten (bias) en de organisatiestructuur.

Voorzover de hoogte van de betreffende variabelen belnvloed worden door de twee eerstgenoemde factoren geldt dat deze random over de organisaties verdeeld zijn te achten, zodat geen systematisch verband te verwachten is.

De variantie die een effect is van de latstgenoemde factor, organisatiestructuur, is object van analyse. Deze zal derhalve in principe verklaard kunnen worden door de ermee te relateren organisatiekenmerken.

ad. b.

De discrepantievariabelen zijn gebaseerd op dezelfde categorleën beoordelaars als de daaraan te relateren organisatiekenmerken. Dit probleem doet zich, zoals reeds eerder opgemerkt, vooral voor bif de arbeldsomstandighedenitems, een in omvang relatief groot deel van de discrepantiescores. Vandaar dat de arbeldsomstandighedenvariabelen slechts in beperkte mate betrokken zijn in de analyses $v$ an de discrepantievariabelen (zle: 4.2.). Bovendien wordt bij deze arbeldsomstandighedenvariabelen uitgegaan van een gemiddelde score over de drie beoordelaars, zodat verschillen tussen beoordelaars worden geneutraliseerd.

Ten aanzien van de overige, onder 3.5. genoemde, discrepantie- 
1tems geldt dat vier organisatlekenmerken - verandering in taken", "werkzekerheid", "verstoring van het productieproces' en 'werkoverleg" - voor een beperkt deel gebaseerd zijn op items die eveneens deel uitmaken van de discrepantievariabelen. Naast de daarbij genoemde items zijn deze organisatiekenmerken bovendien samengesteld uit items, die niet in de discrepantievariabelen zijn opgenomen (Nijhuis en Soeters, 1982). Voorzover het dezelfde items betreffen wordt in de berekening van de organisatiekenmerken de afzonderlijke scores van de beoordelaars gesommeerd, terwij1 bij de berekening van de discrepantievarlabelen uitgegaan wordt $v$ an het verschil.

De betreffende items leveren derhalve slechts een beperkte bijdrage aan de totale discrepantie.

Al met al moet geconcludeerd worden dat, gezilen de verschillende opbouw van de variabelen en het felt dat in de discrepantiescores gewerkt wordt met verschillen, het risico van contaminatie gering 1s. Dit impliceert dat bij de interpretatie van eventuele verbanden tussen elk $v$ an de vier genoemde organlsatiekenmerken en een der discrepantievariabelen met een dergelijk risico rekening gehouden zal moeten worden.

\subsubsection{De analyse}

In hoofdstuk $4 \mathrm{zijn}$ een aantal organisatiekenmerken beschreven die samen kunnen hangen met de grootste mate van de discrepanties in de arbeidsorganisaties. In dit hoofdstuk zullen de discrepantlevariabelen dan ook allereerst geanalyseerd worden als afhankelijke variabelen om de samenhang te ontdekken tussen de verschlllende organisatiekenmerken en de discrepantievariabelen. Daartoe worden een tweetal verschillende technleken gebruikt:

a. multiple regressie-analyse.

Door middel van deze analyse-methode kan het effect (richting en grootte) geanalyseerd worden dat een onafhankelijke variabele heeft op de afhankelijke, waarbij de lnvloed van alle andere onafhankelijke variabelen constant gehouden wordt. Bovendien levert een dergelijke analyse informatle op over welk deel van de variantle van de afhankelijke variabele verklaard wordt door een set van onafhankelijke varfabelen. Deze analyse is in twee fasen uitgevoerd. Allereerst in een voorwaartse stapsgewljze versie, die achtereenvolgens de sterkste verbanden met de afhankelijke variabele te zien geven, onder constanthouding van de andere variabelen. Deze procedure wordt voortgezet, zolang de geselec- 
teerde variabelen een significante F-waarde bezitten. Met deze geselecteerde variabelen wordt dan tenslotte een definitieve multiple regressie analyse uitgevoerd (Nie e.a., 1975).

b. de discriminant-analyse.

Deze statistische techniek maakt het mogelifk te analyseren waarin de arbeidsorganisaties met een hoge discrepantie $z 1 c h$ onderscheiden $v$ an arbeidsorganisaties met een lage discrepantie. Daartoe zijn uit het totaal van de organisaties een tweetal groepen gecreëerd: organisaties met de $40 \%$ hoogste discrepantiewaarde $(\mathrm{N}=17)$ en organisaties met de $40 \%$ laagste discrepantiewaarde $(\mathrm{N}=17)$. De middelste twee decielen worden buiten beschouwing gelaten. Mathematisch beoogt de discriminant-analyse om de onafhankelijke varlabelen op een zodanige wijze te wegen en lineair te combineren dat de beide onderschelden groepen zo (statistisch) verschillend mogelljk zljn (Nle e.a., 1975, Tatsuoka, 1970).

Elk van de drie discrepantiematen zal afzonderlijk op deze beide wijzen geanalyseerd en beschreven worden. Na de beschrijving van de resultaten van deze beide analyses zullen, ten behoeve van de interpretatie, de onderlinge effecten van de organisatiekenmerken, die van invloed zijn op de discrepantie en hun relatie met de betreffende discrepantiemaat nader geanalyseerd worden. Per discrepantievariabele zijn deze drie stappen (multiple regressie, discriminant en onderlinge relaties van de gevonden organisatiekenmerken) hiernavolgend (5.2.2.) weergegeven.

5.2.3. De analyse van de discrepantie tussen het management en het hoofd personeelszaken (Dman-pz)

5.2.3.1. De multiple regressie-analyse van de Dman-pz

De multiple regressie-analyse van de Dnan-pz leverde een zestal significante samenhangen op, weergegeven in tabel 5.4 . 
Tabel 5.4. Resultaten van de multiple regressie-analyse op de Drman-pz.

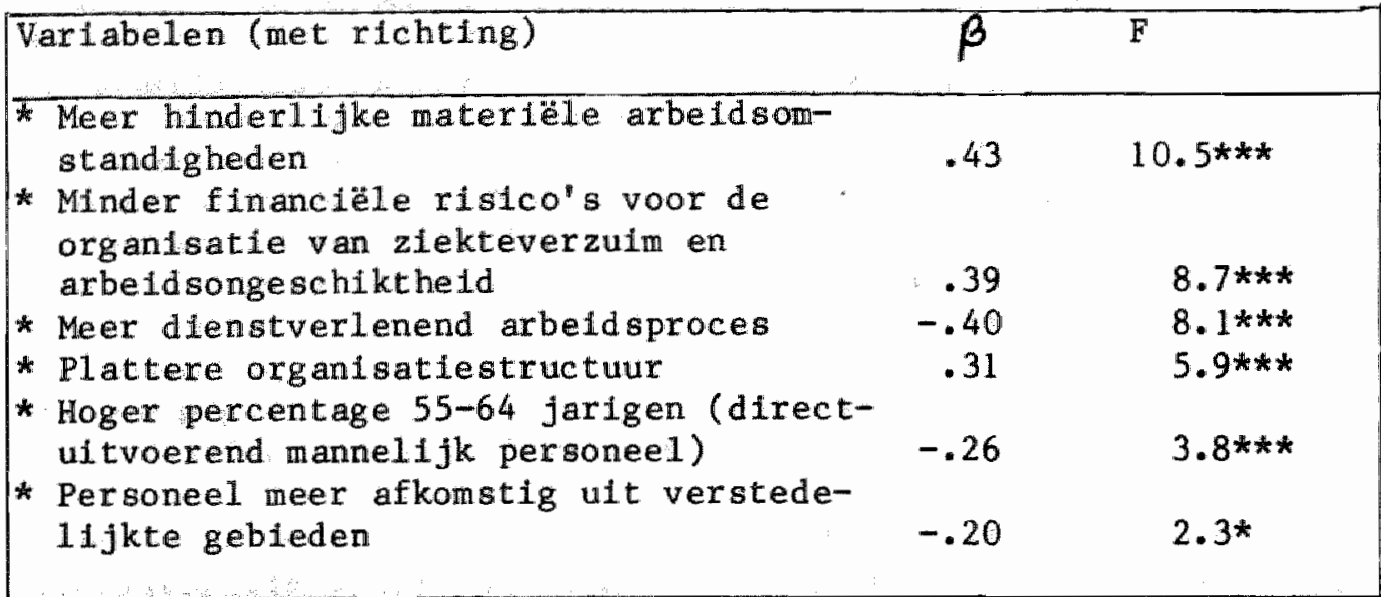

Totaal verklaarde variantie is $56 \%$

$$
\begin{aligned}
& N=42 \\
& (1) N=36 \\
& * * *: p \leqslant 0.01 \\
& * * \quad: 0.01<p<0.05 \\
& * \quad: 0.05<p<0.10
\end{aligned}
$$

De varlantle in de Dman-pz blifkt voor een groot dee1 (56\%) door een zestal organisatiekenmerken verklaard te worden.

ook hier kan geconstateerd worden dat veel hinderlijke arbeldsomstandigheden samengaan met een geringe discrepantie.

De eerste veronderstelling was dat de arbeldsorganisatie qua Informatiemogelfjkheden geslotener is, naarmate de discrepantie groter zal zijn.

Deze geslotenheid van informatiemogelifkheden is geoperationaliseerd middels de volgende variabelen:

-Hïrarchie,

-Mate van technologisering van het productleproces (meer getechnologiseerd is minder discrepantie).

De veronderstelling dat de mate van geslotenheid van de arbeidsorganisatie de discrepantie beInvloedt, wordt gedeeltelijk bevestigd. Conform de verwachtingen blijkt dat binnen een meer dienstverlenend arbeldsproces de discrepantle hoger is, dus naarmate een productieproces meer gemechaniseerd $1 \mathrm{s,}$ is de betrokkenheld 
van het management op het arbeldsproces sterker en daarmee de Dman-pz geringer.

Overeenkomstig de verwachtingen blijkt een plattere organisatiestructuur te leiden tot een geringere discrepantie. Deze geringere $D m a n-p z$ kan op de volgende manier verklaard worden:

Een meer platte organisatiestructuur kent kortere informatiekanalen zodat zowel personeelszaken als het management een gelijke$11 j k e$ "toegang" hebben tot informatie over het arbeldsproces; een arbeidsproces dat veelal eenvoudiger is en dus minder discrepantie toelaat dan bij een steilere hiërarchie het geval is.

De tweede veronderstelling ten aanzien van de relatie tussen de grootte van de Dman-pz en de structuur en positie van de afdeling personeelszaken wordt niet bevestigd.

De derde veronderstelling dat de mate waarin het beleid en de structuur $v$ an de arbeldsorganisatie meer noodzaakt tot interventies, zal leiden tot een geringere discrepantie wordt evenmin bevestigd. Gevonden is dat de discrepantie hoger is, naarmate de organisatie meer financiële risico's loopt door zlekteverzulm en arbeidsongeschiktheid. Mogelijk leidt een hoger financieel risico tot meer activiteiten van de afdeling personeelszaken, met als gevolg een toename van de discrepantie tussen management en personeelszaken.

Een tweetal bevindingen verschijnen onvoorspeld; het betreffen demografische personeelskenmerken. Ten eerste blijkt dat een hoger percentage 55-64 jarigen leidt tot een hogere Dman-pz. Een hoger percentage ouderen duidt op een langer dienstverband, waardoor mogelijk betere interne, informele informattekanalen ontstaan kunnen zijn. Voorzover dit zich uit in betere communficatie zal dit vooral gelden ten aanzien van ofwel personeelszaken, ofwel het management, met als gevolg dat die betreffende groep eerder en beter op de hoogte $1 \mathrm{~s} v$ an problemen en meningen, die bif het personeel bestaan. Dit zal tot een grotere discrepantie tussen de meningen $v$ an managemt en personeelszaken.

De tweede niet verwachte relatie is dat de discrepantie groter is naarmate het personeel meer afkomstig is uft verstedelijkte gebieden. Dit kan eveneens slechts ad hoc verklaard worden.

Een grotere discrepantie tussen management en personeelszaken in samenhang met de herkomst van het personeel moet duiden op een ongelijke toegang van het personeel naar een der belde beoordelaars. Dit wordt ondersteund doordat 'meer stedelijke herkomst van het personeel' samenhangt met een hogere discrepantie tussen personeelszaken en personeelsvertegenwoordiging en niet met de discrepantle tussen management en personeelsvertegenwoordiging. 
5.2.3.2. De discriminant-analyse op de Dman-pz

Ter onderscheiding van de organisatiekenmerken waarin organisaties met een lage discrepantie verschillen van organisaties met een hoge discrepantie is een discriminant-analyse op de Dman-pz ultgevoerd. Bij deze analyse zijn de $40 \%$ organisaties met de hoogste discrepantiewaarden vergeleken met de $40 \%$ van de bedrijven met de lagste discrepantiewaarden.

Bij de analyse is gekozen voor een stapsgewijze versie methode Wilks (SPSS). Het overall criterium is de F-ratlo voor de test op verschillen tussen groepsgemiddelden. Deze toets neemt daarbij in de berekening het versch1l tussen alle middelpunten en de cohesie (homogeniteit) binnen de groep mee. Deze procedure is gevolgd met dezelfde 15 variabelen, die ook in de multiple regressie geanalyseerd zijn.

De gevolgde analyseprocedure werd gestopt, indien

- ofwel de afname van Wilks' labda niet meer significant was (De Wilks' labda is een inverse maat voor het discriminerend vermogen van de oorspronkelijke geselecteerde variabelen). Indien deze bij een volgende stap (toevoeging nieuwe variabele) niet significant kleiner wordt, dan wordt evenmin het discriminerend vermogen tussen groepen $v$ an de geselecteerde variabelen groter;

- of wel de F-waarde van de geselecteerde variabelen onvoldoende was voor verdere berekeningen $(p>.10)$. (Nie e.a., 1975; Tatsuoka, 1970).

Vervolgens is met deze geselecteerde variabelen een directe analyse uitgevoerd.

Bij de analyse van de Dman-pz zijn twee groepen van elk 17 organisatles gecreëerd. Na de analyse bleken drie variabelen met een voldoende $F$-waarde te discrimineren tussen belde groepen (zie voor beschrifving tabel 5.5.). 
Tabel 5.5. Discriminerende variabelen bij de discriminant analyse op de Dman-pz.

\begin{tabular}{|c|c|}
\hline Variabele (met richting) & Discriminantfunctie \\
\hline $\begin{array}{l}\text { * Meer hinderlijke materiële arbeids- } \\
\text { omstandigheden } \\
\text { * Meer dienstverlenend arbeidsproces } \\
\text { * Minder financiële risico's voor de } \\
\text { organisatie van ziekteverzuim en } \\
\text { arbeidsongeschiktheid }\end{array}$ & $\begin{array}{r}-.64 \\
.57 \\
-.44\end{array}$ \\
\hline $\begin{array}{l}\mathrm{N}=34 \\
\mathrm{~F}=8.6^{* * *}(\mathrm{p} \leqslant 0.01) \\
\text { Wilks }{ }^{\prime}: 0.54 \\
\text { chi }: 18.9 * * *(\mathrm{p} \leqslant 0.01) \\
\text { discriminantfunctie: groep } 1 \text { (hoog disc } \\
\text { groep } 2 \text { (1aag disc }\end{array}$ & $\begin{array}{lr}(r e p a n t): & .67 \\
\text { (repant): } & -.67\end{array}$ \\
\hline
\end{tabular}

Deze drie variabelen blijken te corresponderen met de varlabelen die resulteerden uit de multiple regressie-analyse. Wanneer uitgaande van deze drie variabelen opnieuw naar de 42 organisaties gekeken wordt, kan op basls van de waarden op deze variabelen 'blind' voorspeld worden in welke groep zij thulshoren (hoog-)laag discrepanten). Op basis van deze scores is tevens aan te geven tot welke groep de organisaties zouden behoren, die niet in de analyse betrokken $21 \mathrm{jn}(\mathrm{N}=8)$.

Tabel 5.6. Voorspellingsresultaten van de drie organisatiekenmerken naar grootte van de Dman-pz.

\begin{tabular}{|lclc|}
\hline groep & $\begin{array}{l}\text { werkelijk } \\
\text { groeps1idmaat- } \\
\text { schap }\end{array}$ & $\begin{array}{l}\text { voorspeld } \\
\text { hoog } \\
\text { discrepant }\end{array}$ & $\begin{array}{l}\text { groepslidmaatschap } \\
\text { laag } \\
\text { d1screpant }\end{array}$ \\
\hline hoog discrepant & 17 & $13(76,5 \%)$ & $4(23,5 \%)$ \\
niet ingedeeld & 8 & $4(50 \%)$ & $4(50 \%)$ \\
laag discrepant & 17 & $0(0 \%)$ & $17(100 \%)$
\end{tabular}

percentage correcte voorspellingen: $88,2 \%$ 
Het blijkt dat in rulm $88 \%$ van de gevallen de voorspelling goed is, hetgeen aangeeft dat het discriminerend vermogen $v a n$ de variabelen groot is.

5.2.3.3. Onderlinge relaties tussen de organisatiekenmerken en de interpretatie van de gevonden verbanden

In totaal blijken zes varlabelen samen te hangen met de Dman-pz. Ter vereenvoudiging van de interpretatie van deze verbanden en ter verkrijging van een totaalbeeld van de invloed van de organisatlekenmerken op de Dman-pz zijn de onderlinge relaties tussen de gevonden onafhankelijke variabelen geanalyseerd. Dit is gedaan middels een Pearson correlatie-analyse en een partiële correlatie-analyse. Bij deze laatste analyse is de correlatie berekend tussen twee variabelen onder constanthouding van het effect van de overige onafhankelijke variabelen. De resultaten van deze analyses zijn weergegeven in tabe1 5.7 . 
Tabel 5.7. Relaties tussen organisatlekenmerken die gerelateerd zijn aan de Dman-pz.

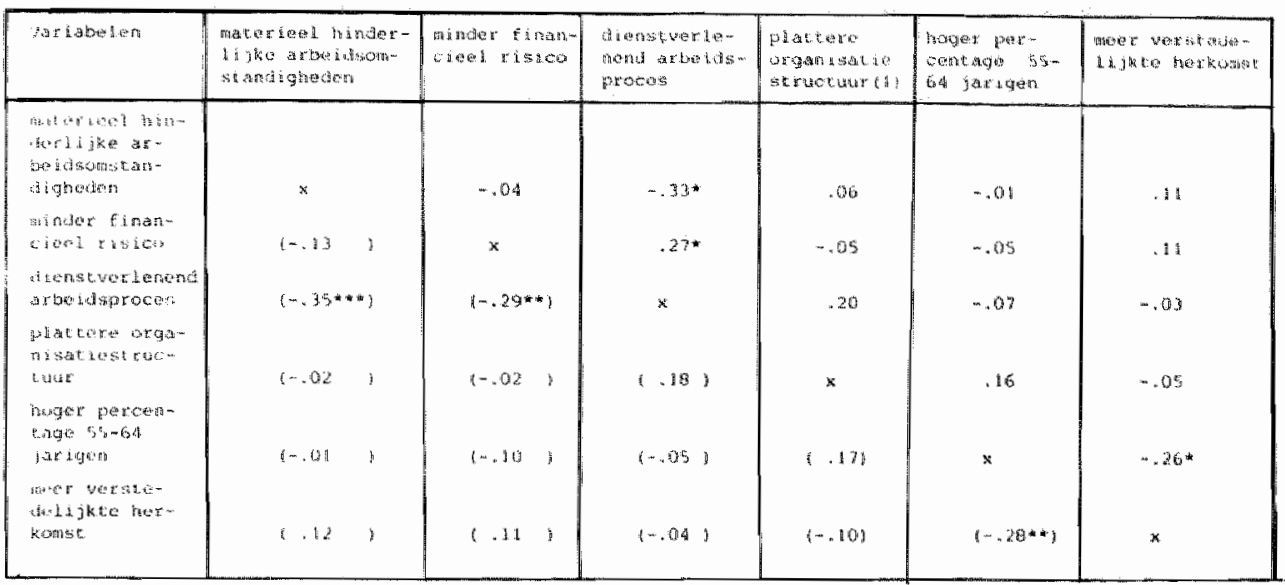

$\mathbb{N}=42$

1) $\mathrm{N}=36$

(...) : ongepartialiseerd,

bij partialisatie en bij organisatiestructuru $N=34$

$* * *: \mathrm{p} \leqslant 0.01$

** $: 0.01<\mathrm{p} \leqslant 0.05$

* $: 0.05<\mathrm{p} \leqslant 0.10$

De onderlinge relaties (na partialisatie) tussen de variabelen die gerelateerd zijn aan de Dman-pz zijn grafisch weergegeven in figuur 5 . 
Figuur 5: Graflsche weergave van de aan de Dman-pz gerelateerde organisatiekenmerken.

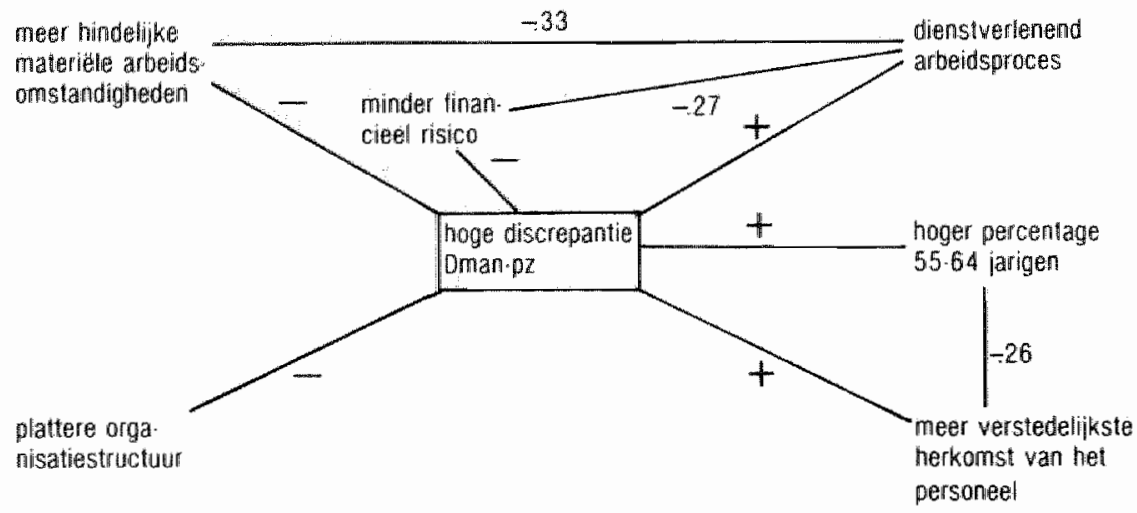

Deze grafische weergave toont dat verschillende clusters een invloed hebben op de discrepantie tussen management en personeelszaken. Het eerste cluster is het arbeldsproces. Naarmate het arbeldsproces eenduldiger is leidt dit tot een geringere discrepantie.

De hiërarchie en de demografische personeelskenmerken zijn de volgende aparte clusters, waarbij het opvallend is dat de demografische kenmerken onderling negatief gecorreleerd $21 \mathrm{jn}$.

De 1 ndruk is dat een kleinere discrepantie vooral samenhangt met organisatiestructuurkenmerken en een grotere discrepantie met personeel saspecten (soctaal klimaat).

5.2.4. De analyse van de discrepantie tussen het management en de personeelsvertegenwoordiging (Dman-pv)

5.2.4.1. De multiple regressie-analyse van de Dman-pv

De multiple regressie-analyse leverde slechts twee significante verbanden op. 
Tabel 5.8. Resultat van de multiple regressie-analyse op de Dnan-pv.

\begin{tabular}{|c|c|c|}
\hline Variabele met richting & $\beta$ & F-waarde \\
\hline $\begin{array}{l}\text { * Veel hinderlijke materiële arbeldsom- } \\
\text { standigheden } \\
\text { * Veel activiteiten op het gebied van } \\
\text { werkstructurering }\end{array}$ & $\begin{array}{c}.32 \\
-.28\end{array}$ & $\begin{array}{l}4.7 * * \\
3.8 * *\end{array}$ \\
\hline
\end{tabular}

verklaarde variantie is $23,3 \%$

$N \quad=42$
$* * \quad: 0.01<p<0.05$

De eerste bevinding komt overeen met de bevinding in par. 5.1.3.: Naarmate er meer hinderlijke arbeldsomstandigheden zijn is de discrepantie kleiner. Verondersteld was dat naarmate de betrokkenheid op het arbeidsproces, met name op technologische gebleden, groter is, de discrepantie kleiner zal zijn. De gevonden relatie is tegengesteld aan de verwachting. Naarmate er meer werkstructureringsactiviteiten ontplooid worden, is de discrepantle ook groter. 'Ad hoc' verklaard kan dit betekenen dat veel werkstructureringsactiviteiten voort komen uit behoeften $v$ an het management (productie-bepaald), waarbij de mening en ldeeën van de werknemers ondergeschikt zijn, maar ook kunnen werkstructureringsactiviteiten veel -niet verwachte- nevenconsequenties met zich mee brengen. Beide vormen kunnen leiden tot een hogere discrepantie. Enerzijds kan de ontvankelijkheid voor andere opvattingen verminderen door sterk uit te gaan van de eigen opvattingen, anderzijds zouden niet verwachte effecten wel geconstateerd kunnen worden door werknemers en niet door het management, vanwege diens aandacht op mogelifk andere gevolgen. In hoofdstuk 4 waren nog twee andere verwachtingen geformuleerd. Deze verwachtingen $z i j n$ niet bevestigd.

5.2.4.2. De discriminant-analyse op de Dman-pv

Analoog aan de in 5.2.2.2. beschreven procedure 1 s de discriminant-analyse op de Dman-pv uttgevoerd. Beide groepen (1aag en hoog discrepanten) bestonden elk uit 17 organisaties.

De discriminant-analyse leverde een viertal varlabelen op ten 
aanzien warvan de belde groepen zich onderschelden. Deze variabelen zijn weergegeven in tabel 5.9 .

Tabel 5.9. Discriminerende variabelen bij de discriminant-analyse op de Dnan-pv.

Varlabelen (met richting)

Discriminantfunctie

* Meer hinderlijke materiële

arbeld somst and igheden

$-.68$

* Meer hinderlijke immaterièle arbeld somst andigheden

* P1attere organisatiestructuur

* Meer gestructureerde vorm van personeelsvertegenwoordiging

$$
\begin{array}{r}
.62 \\
-.54 \\
-.61
\end{array}
$$

$\mathbb{N}=34$

$\mathrm{F}=4.7 * * *(\mathrm{p} \leqslant 0.01)$

Wi $1 \mathrm{ks}, \lambda \quad: .61$

Ch1 : $14.9(\mathrm{p}<0.01)$

discriminantfunctie: groep 1 (hoog discrepant): .62

groep 2 (1aag discrepant): -.62

Zoals uit tabel 5.9. blijkt zijn aan de variabele uit de multiple regressie-analyse een drietal geheel nieuwe verbanden toegevoegd. Conform de bevindingen in paragraaf 5.1.3. blijken slechte materlële arbeldsomstandigheden samen te gaan met een geringe Dmanpv, terwijl slechte lmmateriële arbeldsomstandigheden samen blifken te hangen met een hoge Dman-pv. Overeenkomend met de verwachtingen is dat een meer gestructureerde vorm van personeelsvertegenwoordiging leidt tot een geringere discrepantle tussen management en personeelsvertegenwoord1ging. Eveneens overeenkomstig de verwachtingen is dat een plattere organisatiestructuur samen blijkt te gaan met een geringere discrepantie tussen management en personeelsvertegenwoordiging. Dit betekent dat een plattere organisatle zowel samengat met een geringere Dman-pz, als een geringere Dman-pv. Zoals reeds eerder gesteld wordt een dergelijke platte organisatievorm juist dan gekozen Indien de werkzaamheden eenduldig en goed te overzien zijn (zie ook: Veen, 1980b).

Uitgaande van deze vier discriminerende variabelen kan 'blind' voorspeld worden welke van de 34 organlsaties behoren tot de 
organisaties met een lage discrepantie en welke tot de organisaties met een hoge discrepantie. Indien een dergelifke voorspellingstest gedaan wordt levert dit de onderstaande verdeling op (tabel 5.10). Ook de niet in de analyse betrokken arbeldsorgantsaties zijn op basis van de scores op deze discrepantievariabelen ingedeeld.

Tabel 5.10. Voorspellingsresultaten op basis van de vier discriminerende organisatiekenmerkvariabelen op de grootte van de Dman-pv.

\begin{tabular}{|lcrc|}
\hline groep & $\begin{array}{l}\text { werkelijk } \\
\text { groepslidmaat- } \\
\text { schap }\end{array}$ & $\begin{array}{l}\text { voorspeld groepslidmaatschap } \\
\text { hoog discrepant 1aag discrepant }\end{array}$ \\
\hline hoog discrepant & 17 & $13(76,5 \%)$ & $4(23,5 \%)$ \\
ongegroepeerd & 8 & $4(62,5 \%)$ & $13(37,5 \%)$ \\
laag discrepant & 17 & $5(23,5 \%)$ & $13(76,5 \%)$ \\
\hline
\end{tabular}

$\mathrm{N}=34$

percentage correcte voorspellingen: $76,5 \%$

Ofschoon het percentage correcte voorspellingen lager is dan het percentage juiste voorspellingen bij de Dman-pz, kan ook hier gesproken worden van een groep varlabelen, die goed in staat is te discrimineren tussen organisaties met een hoge en lage discrepantie.

5.2.4.3. Onderlinge relaties tussen de organlsatlekemmerken en de interpretatie van de daartussen gevonden verbanden

Een vijftal organisatiekenmerken zijn van invloed op de Dman-pv. om de interpretatie van deze discrepantiemat te vereenvoudigen zullen de onderlinge relaties tussen de betreffende variabelen worden aangegeven, evenals hun verband met de Dman-pv. Analoog aan de in 5.2.2.3. gevolgde pracedure zal dit gebeuren middels een Pearson correlatie-analyse en een partiële correlatie-analyse, waarbij de effecten van de variabelen, die niet direct in de correlatie-analyse betrokken $z i j n$, ultgeschakeld worden. Deze relaties zifn weergegeven in tabel 5.11 . 
Tabel 5.11. Relaties tussen de organisatiekenmerken die gerelateerd zljn aan de Dman-pv.

\begin{tabular}{|c|c|c|c|c|c|}
\hline 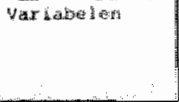 & 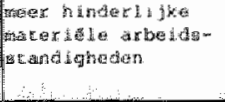 & 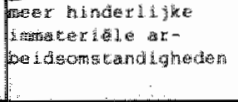 & 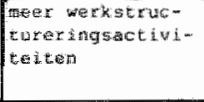 & $\begin{array}{l}\text { platiere orga- } \\
\text { risative strue- } \\
\text { tulux }\end{array}$ & $\begin{array}{l}\text { weer gestractu- } \\
\text { rear de perso- } \\
\text { neelsvertegen- } \\
\text { woordiging }\end{array}$ \\
\hline 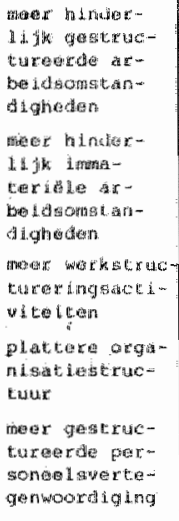 & $\begin{array}{l}(-.0 B) \\
(-.24) \\
(-.02) \\
(\cdots+2)\}\end{array}$ & $\begin{array}{l}x \\
(.33 \times 4) \\
(.15) \\
(.30 * 4)\end{array}$ & $\begin{array}{l}-.25 * \\
.36 * k \\
* \\
1.4 .9 \\
1-.06 \quad 1\end{array}$ & $\begin{array}{l}. .05 \\
.26 \% \\
-.00 \\
\times 6 \\
0-.34+4)\end{array}$ & $\begin{array}{l}.41 \cdots \cdots \\
-.20 \\
-.40 \% \cdots * \cdots \\
x\end{array}$ \\
\hline
\end{tabular}

$$
\begin{aligned}
& N=42 \\
& 1) N=36 \\
& (\ldots)=\text { ongepartial seerd }
\end{aligned}
$$

$\mathrm{Na}$ partialisering: $\mathrm{N}=36$

$\star * *: \mathrm{p} \leqslant 0.01$

$* *: 0.01<\mathrm{p} \leqslant 0.05$

* $\quad: 0.05<\mathrm{p} \leqslant 0.10$

Grafisch kan dit weergegeven worden zoals in figuur 6. 
Figuur 6: Grafische weergave van de aan de Dman-pv gerelateerde organisatiekenmerken.

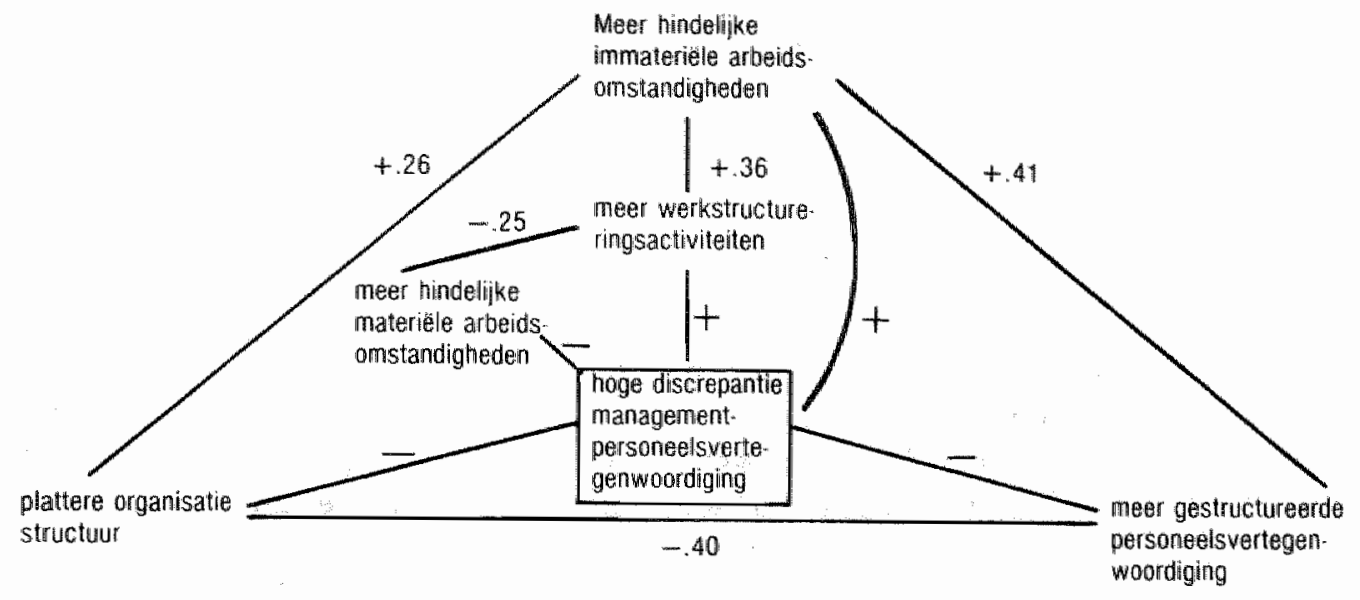

De grafische weergave lat een reeks van relaties zien, die echter niet altijd consistent zijn. Dit impliceert bijvoorbeeld dat een ander deel van de variantie verklaard wordt door het effect van de organisatiestructuur, dan door de aard van de personeelsvertegenwoordiging. Ook hier bestat de Indruk dat de structuurvariabelen een meer beperkende Invloed op de discrepantie hebben, terwijl de veranderingsvariabelen en de minder objectiveerbare immateriële arbeidsomstandigheden een vergrotende invloed op de Dman-pv hebben.

5.2.5. De analyse van de discrepantie tussen het hoofd personeelszaken en de personeelsvertegenwoordiging (Dpz-pv)

5.2.5.1. De multiple regressie-analyse van de Dpz-pv

De multiple regressie leverde slechts een enkele variabele op (tabe1 5.12.). 
Tabel 5.12. Resultaat van de multiple regressie-analyse op de Dpz-pv .

varlabele (met richting)

B F-waarde

veel activiteiten gericht op

werkstructurering

$-.252 .8 *$

$\mathrm{N}=42$

* : $0.05<p \leqslant 0.10$

verklaarde variantie $=7 \%$

Deze variabele komt overeen met de gevonden variabele in de multiple regressie-analyse van de Dman-pv. Voor een verklaring wordt verwezen naar 5.2.3.1.

De drie verwachtingen die ten aanzien van de Dpz-pv, in hoofdstuk 4, zijn geformuleerd, worden niet door de resultaten bevestigd. Deze verwachtingen waren: naarmate de structuur en het scala van activiteiten van personeelszaken uitgewerkt is, zal de Dpz-pv kleiner zijn.

Naarmate het noodzakelijker is informatie over de organisatie te vergaren, $z a l$ de Dpz-pv kleiner zijn.

Naarmate een arbeidsorganisatie minder gesloten informatiekanalen kent, wordt de discrepantie tussen de beoordeling van het hoofd tussen personeelszaken en die van de leden van de personeelsvertegenwoordiging kleiner.

5.2.5.2. De discriminant-analyse op de Dpz-pv

De discriminant-analyse levert eveneens slechts één variabele op die bepalend is voor de verschillen in discrepantie tussen arbeidsorganisaties (tabe1 5.13). 
Tabel 5.13. Discriminerende variabelen bij de discriminant-analyse op de Dpz-pv.

variabele (met richting)

Discriminantfunctie

Fersoneel komt meer ult verstedelifkte

gebieden

1.00

$\mathrm{N}=34$

$F \quad=5.6 * *(0.01<\mathrm{p} \leqslant 0.05)$

Wilks' $\lambda=.85$

chi $=5.1 .(p=.02)$

discriminantfunctie groep 1 (hoog discrepant): .38

groep 2 ( 1 aag discrepant): -.38

Naarmate het personeel meer afkomstig is uit verstedelijkte gebieden is de discrepantie tussen personeelszaken en personeelsvertegenwoordiging hoger. De verklaring voor deze bevinding is reeds gegeven bij de beschrijving van de relatie tussen deze verstedelijkingsvariabele en de Dman-pz (paragraaf 5.2.3.1.).

Hoewel slechts één variabele gevonden is die significant discrimineert tussen arbeldsorganisaties met een hoge en met een lage waarde op de Dpz-pv is toch voorspeld tot welke groep de 34 organisaties behoren op basis van de score op de 'verstedelijkings'-variabele. Dit levert de in tabel 5.14 vermelde resultaten op.

Tabel 5.14. Voorspellingsresultaat op basis van het ene discriminerende organisatiekenmerk op de grootte van de $\mathrm{Dpz}-\mathrm{pv}$.

\begin{tabular}{|lccc|}
\hline groep & $\begin{array}{l}\text { werkelijk } \\
\text { groepslidmat- } \\
\text { schap }\end{array}$ & $\begin{array}{l}\text { voorspeld } \\
\text { hoog } \\
\text { discrepant }\end{array}$ & $\begin{array}{l}\text { groepslidmaatschap } \\
\text { laag } \\
\text { discrepant }\end{array}$ \\
\hline $\begin{array}{l}\text { hoog discrepant } \\
\text { ongegroepeerd } \\
\text { laag discrepant }\end{array}$ & 17 & $10(58.8 \%)$ & $7(41.2 \%)$ \\
& 17 & $4(50 \%)$ & $4(50 \%)$ \\
\hline
\end{tabular}

$\mathrm{N}=34$

Percentage correcte voorspellingen: $61,8 \%$ 
Te verwachten was dat het voorspellingsresultat op basis van efn varlabele nlet hoog zou ultvallen. Op basis van die ene variabele wordt bijna $62 \%$ van de gevallen goed voorspeld. Arbeidsorganisatles met een lage waarde op de discrepantlevariabele worden vaker goed geclassificeerd dan arbeldsorganisaties met een lage waarde op de discrepantievariabelen.

5.2.5.3. Onderlinge relaties tussen de organisatiekenmerken en de interpretatie van de daartussen gevonden verbanden

De gevonden twee variabelen blijken onderling niet gerelateerd te zijn $(r=-.09)$. Terwijl werkstructurering in relatie tot de Dpz-pv qua richting overeenkomt met de gelijke relatie bij de Dman-pv, is de relatie tussen de Dpz-pv en de mate waarin het personeel gerecruteerd wordt uit meer verstedelijkte gebieden tegengesteld is aan de relatie tussen de verstedelijkingsvariabele en de Dman-pv. B1ijkbaar zijn hier verschillende processen werkzaam. Bij de verklaring van het verband tussen de Dman-pv en de 'verstedelijkings'-variabele 1 s gewezen op de meer Instrumentele arbeldsopvatting van deze groep werknemers, waardoor eerder kl achten, opmerkingen e.d. naar voren zullen komen.

De eerste opvang van deze $\mathrm{klachten}$ gebeurt allicht door de afdeling personeelszaken. Mogelijk heeft de regelmatige confrontatie met "mopper"-gedrag een contrast-werking, welke aanleiding is tot een defensieve attitude, in de zin van: "het is in deze organisatie niet zo slecht als ze zeggen", waardoor de afstand tussen afdeling personeelszaken en de overige werknemers groeit (hoger $\mathrm{Dpz}-\mathrm{pv}$ ); conform de cognttleve dissonantietheorle (Festinger, 1957).

De veronderstellingen, zoals weergegeven in 5.2.4.1. blijken niet bevestigd te worden door de bevindingen. Blijkbaar wordt de discrepantie tussen personeelszaken en personeelsvertegenwoordiging door andere factoren veroorzaakt dan hier voorspeld. Ook het geringe antal significante relaties met de Dpz-pv wijst in dezelfde richting. Vanwege deze teleurstellende bevindingen is een aanvullende analyse gedaan op de Dpz-pv.

5.2.5.4. Aanvullende analyse betreffende de Dpz-pv

Uitgaande van de onafhankelijke varlabelen zoals beschreven in 'Werk en Zlekte' (Nijhuis en Soeters, 1982) is een stapsgewijze multiple regressie-analyse uitgevoerd op de Dpz-pv. Vervolgens is met de variabelen die een voldoende $F$-waarde hadden een slotana- 
lyse gedaan. De resultaten $z i j n$ weergegeven in tabel 5.15 .

Tabel 5.15. Aanvullende Multiple regressie-analyse op de discrepantie tussen personeelszaken en personeelsvertegenwoordigig.

\begin{tabular}{|c|c|c|}
\hline Variabele (met richting) & $\beta$ & $\bar{F}$ \\
\hline $\begin{array}{l}\text { * Meer activitelten gericht op opleiding } \\
\text { en omscholing } \\
\text { * Meer intensieve vormen van ploegendienst } \\
\text { * Meer activiteiten gericht op de opspo- } \\
\text { ring van slechte arbeldsomstandigheden } \\
\text { * Meer activiteiten op het gebied van } \\
\text { werkstructurering } \\
\text { * Meer overleg van contacten met langdurig } \\
\text { zieke werknemers } \\
\text { * Meer verstoring van het arbeidsproces } \\
\text { t.g.v. zlekteverzulm en arbeidsonge- } \\
\text { schiktheid }\end{array}$ & $\begin{array}{l}-.66 \\
-.38\end{array}$ & $\begin{array}{c}19.6 * * * \\
7.7 * * * \\
6.3 * * *\end{array}$ \\
\hline
\end{tabular}

totaal verklaarde varlantie $50 \%$

$\mathrm{N}=42$

$* * *: \mathrm{p} \leqslant 0.01$

$* * \quad: 0.01<\mathrm{p} \leqslant 0.05$

Een zestal organisatieaspecten blijken duldelijk samenhang te vertonen met de $D p z-p v$ en een groot deel van de variantie in de Dpz-pv verklaren. Slechts éen varlabele komt overeen met de eerder besproken verbanden. Conform de tendens van de eerder geformuleerde veronderstellingen blijken activiteiten vanult personeelszaken gericht op het personeel bif te dragen tot een 1 agere discrepantie. Deze relatie wordt bevestigd door de bifdrage aan een lagere discrepantie tussen de afdeling personeelszaken en de personeelsvertegenwoordiging door:

- meer activiteiten gericht op opleiding en omscholing,

- meer contact en overleg met langdurig zleke werknemers,

- meer verstoring van het arbeldsproces ten gevolge van zlekteverzulim en arbeldsongeschiktheid.

Niet doorzichting is de relatie van de Dpz-pv met meer intensieve vormen $v$ an ploegendlenst. Mogelijk leiden meer intensleve vormen van ploegendienst tot meer sociale contacten met werknemers, 
waardoor een lagere Dpz-pv ontstaat; ook kunnen de werkzaamheden die in ploegendienst worden verricht en de arbeidsomstandigheden, waaronder gewerkt wordt, meer eenduidig zijn en daarom minder discrepantie toelaten (vergelijk met 5.1 .3$. ).

Moeliljk interpreteerbaar is dat meer activiteiten gericht op het opsporen van slechte arbeldsomstandigheden lefden tot een hoge discrepantle tussen het hoofd personeelszaken en de personeelsvertegenwoordiging. Door veel activiteiten, gericht op de opsporing van slechte arbeldsomstandigheden, kan een discussie aangewakkerd worden over de "kwaliteit" van de arbeidsomstandigheden: een discussle die polarlserend werkt op de beoordeling van beide respondenten. Tevens kunnen veel opsporingsactiviteiten leiden tot 'harde', objectieve gegevens, die als maatstaf gelden voor de beoordeling $v$ an personeelszaken $v$ an de arbeldssituatie, terwijl voor de personeelsvertegenwoordiging julst subjectieve ervaringen belangrijk zijn. Het afzetten van deze belde beoordelingen tegen elkaar zou dan eveneens kunnen lelden tot een hoge Dpz-pv.

Ofschoon in eerste instantie de analyses geen inzicht geven in de bron van de Dpz-pv, suggereren de bevindingen van de uitgevoerde 'zoek-analyses, dat de Dpz-pv vooral bepaald wordt door die activiteiten, die contacten inhouden met werknemers. Vandaar de conclusle dat de $\mathrm{Dpz}-\mathrm{pv}$ net als de overige twee discrepantiematen een reëel organisatiekenmerk is.

5.3 . Samenvattende bevindingen

De door middel van de multiple regressie-analyse en de discrminant-analyse geconstateerde relaties tussen de organisatiekenmerken en de discriminant-analyse zullen hier samengevat worden weergegeven.

In tabel 5.16. worden alle relevante variabelen vermeld, met ultzondering van de variabelen genoemd onder 5.2.5.4., waarbij een ' + ' betekent dat de betreffende varlabele samengaat met een hoge discrepantie en een '-' met een lage discrepantie. 
Tabel 5.16. Samenvattende bevindingen tussen de organisatiekenmerken en de drie discrepantievariabelen.

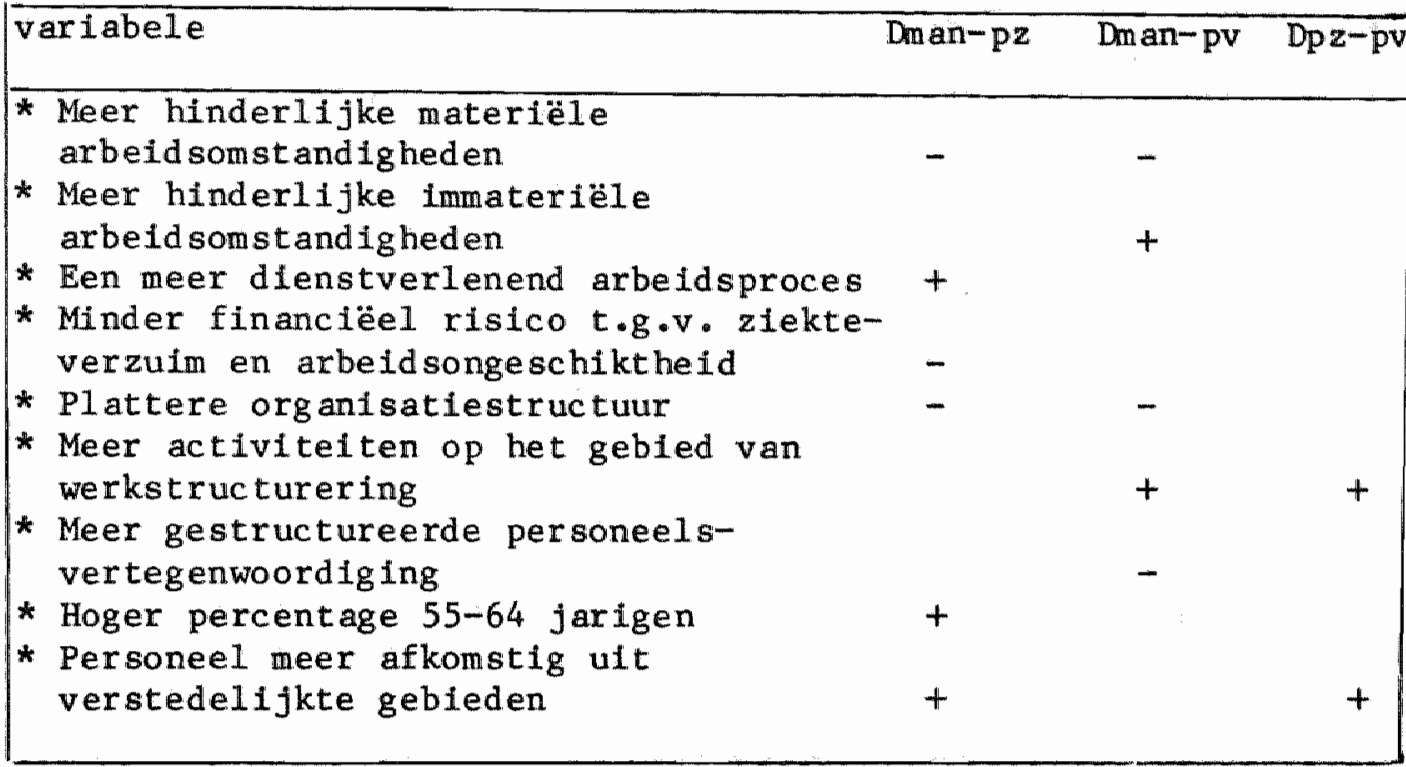

Een viertal variabelen blijken twee van de drie discrepantiematen te beinvloeden, waarvan eén een tegengestelde relatie heeft met twee discrepantilematen. Overigens vertonen de drie discrepantievariabelen een zeer eigen samenhang met de betreffende organisatiekenmerken. Dit pleit ervoor ze als eigenstandige organisatiekenmerken te beschouwen.

5.4 Discrepantle en de indicatoren voor verzulm en arbeidsongeschiktheid

5.4.1. Correlaties tussen de discrepantievariabelen en de verzuim- en arbeldsongeschiktheidsindicatoren

De onderzoeksvraagstelling naar de relatie tussen organisatiekenmerken en de drie verzuim- en arbeldsongeschiktheidsindicatoren roept in deze tevens de vraag op naar de mate waarin verschillen tussen de diverse beoordelaars samenhangen met deze indic atoren.

In tabel 5.17 worden de correlaties tussen deze drie verzuim- en arbeidsongeschiktheidsindicatoren enerzijds en de drie discrepan- 
tiematen anderzijds zowel gepartialiseerd als ongepartialiseerd weergegeven. Bij de partlalisering wordt zowel het effect van de belde, niet in de analyse betrokken, discrepantievariabelen, als de frequentie en duur, bij respectlevelijk de analyse van de relaties met verzulmduur en -frequentie statistisch constant gehouden. Dit laatste gebeurt omdat frequentie en duur een logisch negatief verband bezitten (Philipsen, 1969a; Nijhuis en Soeters, 1982). Ten aanzlen van de relatie tussen een discrepantievariabele en het aantal WAO/IP toetredingen is niet gepartialiseerd voor frequentie en duur, doch slechts voor de overige twee discrepantievariabelen.

Tabe1 5.17. Gepartialiseerde en ongepartialiseerde correlaties tussen de arbeldsongeschiktheidsindicatoren en de drie discrepantiematen.

\begin{tabular}{|c|c|c|c|}
\hline & Dman-pz & Dman-pv & $\overline{\mathrm{Dp} z-\mathrm{pv}}$ \\
\hline Verzuimf requentie & $.45 * * *(.39 * * *)$ & $-.03(-.13)$ & $.10(.03)$ \\
\hline Verzulmduur & $.28^{* * *}(.17)$ & $.33 * * *(.37 * * *)$ & $.04(.10)$ \\
\hline WAO/IP toetredingen & $(.20 *)$ & $.13(.17)$ & $.11(.14)$ \\
\hline
\end{tabular}

$\mathrm{N}=40$

$\star * *: p \leqslant 0.01$

$* *: 0.01<p \leqslant 0.05$

* : $0.05<p \leqslant 0.10$

( ) : ongepartialiseerd

Het afwijkende aantal $(N=40)$ is het gevolg van het felt dat niet alle organisaties over de gevraggde gedetailleerde verzuimgegevens van de groep direct-uitvoerend, mannelijk personeel beschikken. Na partialisering blijkt een hoge mate van discrepantie tussen management en personeelszaken (dman-pz) samen te gaan met een lage verzuimduur en verzuimfrequentie. Een lage verzuimduur blijkt tevens samen te hangen met de discrepantie tussen management en personeelsvertegenwoordiging (Dman-pv). Alvorens deze verbanden kunnen worden geinterpreteerd is het noodzakelijk, middels een multiple regressie-analyse, te bezien in welke mate deze discrepantiematen b1jdragen leveren in de verklaring van de variantie van de drie verzuim- en arbeidsongeschiktheidsindicatoren. 
Tabel 5.18. Multiple regressie-analyse van het effect van de discrepantievariabele op de verzuim- en arbeidsongeschikt heidsind Icatoren.

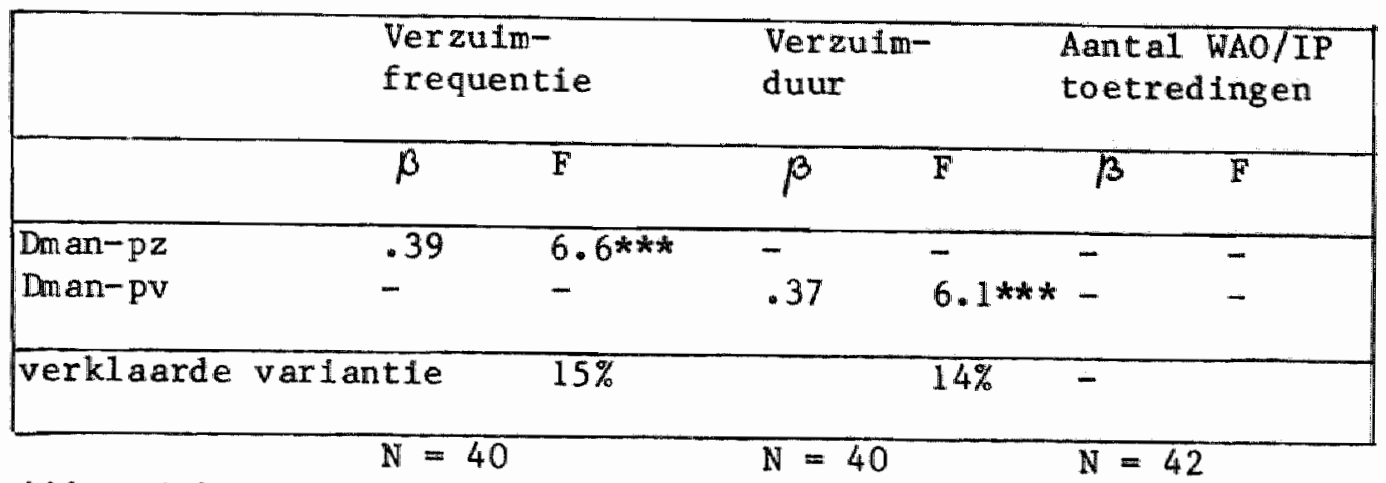

$* * * \quad p \leqslant 0.01$

5.4.2. Interpretatie van de relaties tussen de verzulm- en arbeidsongeschiktheidsindicatoren en de discrepantiematen

Uit tabel 5.18 blijkt dat de verzuimdur en verzuimfrequentie vooral an twee verschillende discrepantiematen gerelateerd zijn: Een gemiddeld lagere verzuimfrequentie blijkt samen te gaan met een hoger Dnan-pz terwijl een gemiddeld kortere verzuimduur samenhangt met een hogere Dman-pv. De bevindingen uit de partièle correlatie analyse worden ook weer bij de multiple regressie-ana1 yse teruggevonden, waarbij de relatie tussen de Dman-pz en de verzuimduur wordt weggedrukt door het grote verschil van de Dman-pv .

De relaties tussen de verzuimfrequentle en de Dman-pz is goed verklaarbaar. In het algemeen wordt in arbeldsorganisaties het kortdurend zieteverzuim het meest storend gevonden. Het korte verzuim betekent namelijk dat er steeds opnieuw ad hoc oplosaingen gevonden dienen te worden voor de door het verzulm ontstane problemen. Deze ad hoc oplossingen zullen vooral gevonden moeten worden door personeelszaken, soms door de productielelding en vaak ook in samenspraak. Deze door de hoge verzulmfrequentie noodzakelijke interventies lelden daardoor tot geregeld overleg resulterend in een lage Dman-pz. De relatile tussen een geniddeld 1 angere verzuimduur en een lagere Dan-pv is verklaarbaar vanuit de veronderstelling, dat bij een lage Dman-pv belde groepen een hoge mate van overeenstemming hebben over de kwallteit van de 
arbeld. Indien dit oordeel zeer negatief is $z$ al 1 angduriger verzulm als meer legitiem ervaren worden en zal vanult de organisatie minder controle plaatsvinden dan bij een hoge mate van discrepantie.

Er blijkt geen relatie te bestaan tussen het aantal WAO/IP toetredingen en de discrepantiematen. Vandaar dat deze laatste arbeldsongeschiktheidsvariabelen ook nlet verder in de analyses betrokken zullen worden.

5.4.3. Verzuimindicatoren en organisatiekenmerken

In de gehanteerde verklaringen tussen ziekteverzuim- en arbeldsongeschiktheidsindicatoren nemen de arbeidssituatie en arbeldsomstandigheden een belangrijke plaats in, vandaar dat in deze paragraaf nagegaan wordt in welke mate de discrepantiescores kunnen bijdragen aan de kennis over de verzuimindicatoren. Daartoe is een analyse gedaan van de verzulmfrequentie en verzulmduur met behulp van de variabelen, warvan uit eerder onderzoek naar de relatie tussen organisatiekenmerken en deze verzuimindicatoren (Nijhuis en Soeters, 1982) bekend is dat zij een groot deel van de varlantie in de verzulmindicatoren verklaren. Met die varlabele die, middels een multiple regressie-analyse in dat onderzoek geselecteerd waren, is een nieuwe multiple regressie-analyse gedaan over het onderhavige databestand. De resultaten daarvan $z i j n$ weergegeven in tabel 5.19 .

Vervolgens zijn aan deze organisatiekenmerken, die een belangrijk deel van de variantie in verzuimfrequentie en -duur verklaren, de discrepantievarlabelen toegevoegd. Daarmee is opnieuw een multiple regressle-analyse ultgevoerd, ter bepallng of deze discrepantiematen een toegevoegde waarde hebben aan de verklaring $v a n$ de verzuimduur en verzuimfrequentie. Dok deze resultaten zijn weergegeven in tabel 5.19 . 
Tabe1 5.19. Resultaten van de multiple regressie-analyse en de verzuimindic ato ren.

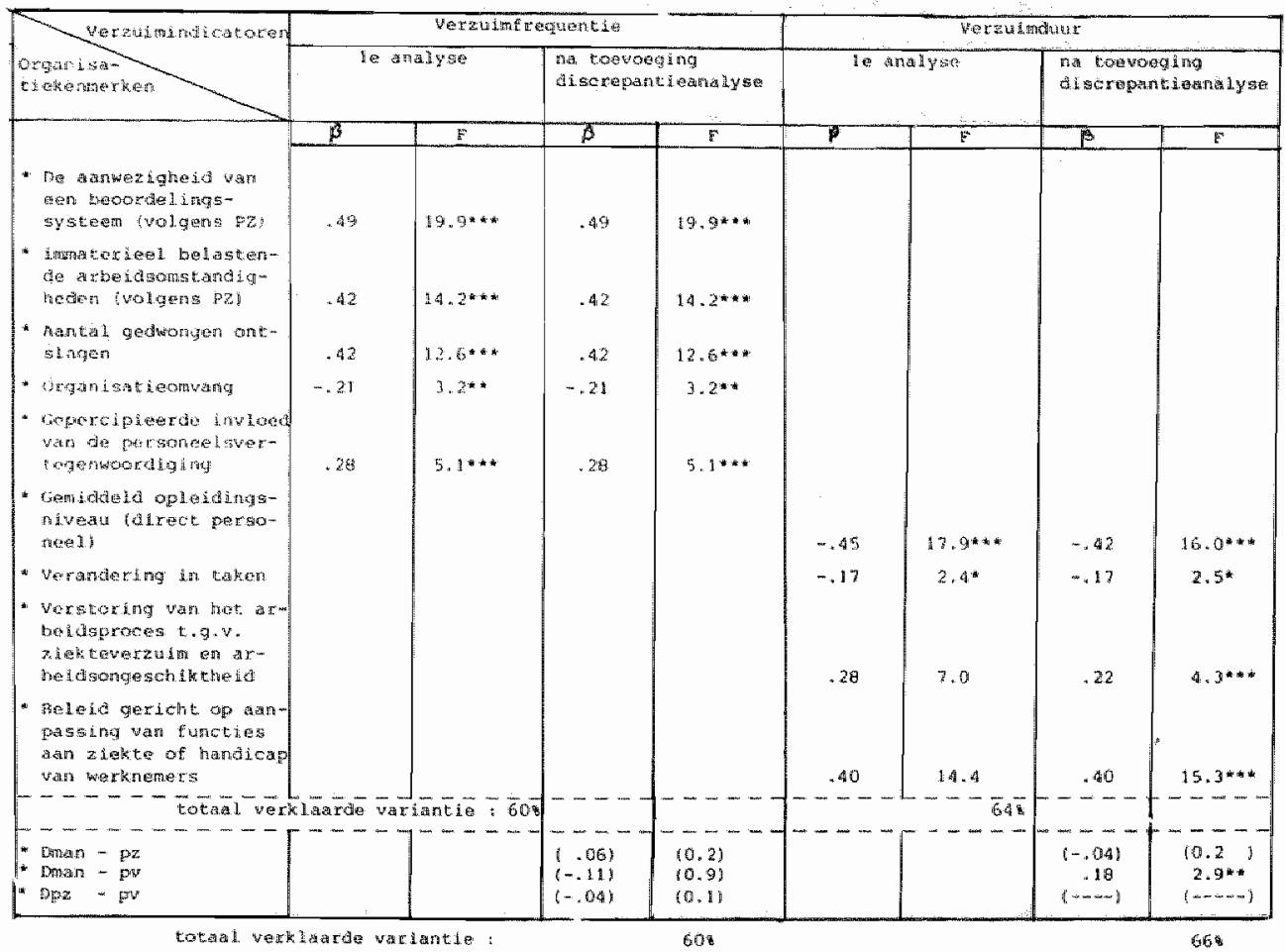

$$
\begin{array}{ll}
\mathrm{N} & =40 \\
* * * & : \mathrm{p} \leqslant 0.01 \\
* * & : 0.01<\mathrm{p}<0.05 \\
* \quad: 0.05<\mathrm{p}<0.10
\end{array}
$$


Bij de verklaring van de variantie in de verzuimindicatoren blijkt ultsluitend de Dman-pv een extra bijdrage te leveren en wel aan de verklaring van de variantie in verzuimduur. Dit verband komt overeen met de bevindingen in 5.4.1.

5.4.4. Conclusies ten aanzien van de relatie tussen de verzulmindicatoren en de discrepantievariabelen

In paragraaf 5.2 . Is de samenhang aangetoond van de discrepantiematen met verschilende organisatiekenmerken. Gebleken is dat deze samenhang $z$ ich slechts in beperkte mate doorzet ten aanzien van de verzulmindicatoren. Over het geheel genomen blijken, ondanks de gevonden verbanden tussen de verzuimindicatoren en de discrepantievariabelen, deze relaties weinig extra's bij te dragen aan de analyse van de verzuimproblematlek in de organisatie. Dit met uitzondering van de relatie tussen Dman-pv en de verzuimduur. 
HOOFDSTUK 6. DISCREPANTIE-ITEMS NADER BELICHT

6.1. Inleiding

In het voorafgaande hoofdstuk $z 1 j n$ discrepanties beschouwd als organisatiekenmerken. Een dergelijke benadering geeft weinig concrete inzichten in de structuur van de discrepantie. De vraag blijft ten aanzien van welke organisatiekenmerken binnen de organisatie grote overeenstemming bestaat en ten aanzien $v a n$ welke organisatiekenmerken deze overeenstemming ontbreekt. In dit en in het volgende hoofdstuk zal ingegaan worden op verschillen in beoordeling ten aanzien van een aantal specifleke organisatieaspecten; betreffende variabelen zullen afzonderlifk geanalyseerd worden naar de mate waarin ten aanzien van die variabelen verschillen en overeenkomsten tussen beoordelaars bestaan.

6.2. Beschrijving van de discrepantie-items

Van de items, die een bijdrage hebben geleverd aan de berekening van de discrepantievariabele (zie 3.7.), zijn een beperkt aantal 1 tems gekozen ter nadere analyse. Bij de keuze van deze 1 tems is vooral gekeken naar de mate warin deze items een ingang vormden ten aanzien van een bepaalde problematlek. Zo is wel de vraag opgenomen of personeelsleden in dit bedriff regelmatig beoordeeld worden, maar niet de vervolgvragen naar de wijze, het doel, welk percentage en dergelijke. Daarnaast behoren ook de gesommeerde arbeldsomstandighedenscores tot de kernitems. Soms is er voor gekozen om enkele 'doorvraag'-items in de analyse op te nemen. Dit is dan gebeurd ofwel ter controle van het ingangsitem, daar mogelijke verschillen ten aanzlen $v$ an het ingangsitem moeten verdwijnen bif de 'doorvraag'-item, ofwel ondat de "doorvraag"items relevante extra informatie geven. Vandaar dat bifvoorbeeld naast de vraag over het voorkomen van werkoverleg ook enkele kenmerken van dat werkoverleg in de analyse zijn betrokken. Indien de perceptie over de mate waarin werkoverleg voorkomt verschillend is, kan desondanks wel overeenstemming bestaan ten aanzien van de structuur van het overleg. 
In tabel 6.1. staan de voor analyse gekozen items vermeld; de statistische kenmerken en hun betekenis worden weergegeven in b1jlage 5 .

Tabe1 6.1. De afzonderlijk te analyseren discrepantie-1tems.

Discrepantle-1tems: hoofd productle versus hoofd personeelszaken:

1. Somatie "hinder van materiele arbeldsomstandigheden',

2. Sommatie "hinder van immaterlële arbeldsomstandigheden',

3. Zijn er meet- en registratiesystemen aanwezig om mogelijk fysiek gezondheidsbedrelgende werkomstandigheden vast te stellen?

Discrepantie-items: tussen hoofd productie versus de personeelsvertegenwoordiging:

1. Sommatie "hinder van materiële arbeldsomstandigheden',

2. Sommatie 'hinder van immateriéle arbeidsomstandigheden',

3. Zljn er meet- en reglstratiesystemen aanwezig om mogelijk fystek gezondheidsbedreigende werkomstandigheden vast te stellen?

4. Is er in de periode 1977-1980 sprake geweest van werktijdverkorting?

5. Is er in de periode 1977-1980 sprake geweest van natuurlifke afvloeting?

6. Is er in de periode 1977-1980 sprake geweest van gedwongen ont slagen?

7. Is er in de perlode 1977-1980 sprake geweest van reorganisat1es?

8. Hebben zich ontwikkelingen op het gebled van automatisering voorged aan?

9. Hebben zich ontwlkkelingen op het gebled van mechanisering voorged aan?

10. Heeft dit geresulteerd in verhoging $v$ an het arbeidstempo?

11. Heeft dit geresulteerd in functleverruiming?

12. Heeft dit geresulteerd in functievereniging?

D1screpantie-1tems: hoofd personeelszaken versus de personeelsvertegenwoord $1 \mathrm{~g} 1 \mathrm{ng}$

1. Sommatle hinder van materiëel bezwarende arbeldsomstandigheden

2. Sommatle hinder van immaterlëel bezwarende arbeidsomstandigheden

3. Zijn er meet- en registratiesystemen in het bedrijf aanwezig? 
4. Worden de personeelsleden in dit bedriff regelmatig beoordeeld in een functioneringsgesprek?

5. Kunt $U$ een oordeel geven over de personeelsbezetting in deze vestiging in 1977 ?

6. Kunt $U$ een oordeel geven over de personeelsbezetting in deze vestiging in 1980 ?

7. Is er sprake van onvervul bare vacatures?

8. Bestaat er een gestructureerd en met regelmaat voorkomend werkoverleg in deze vestiging?

9. Kent dit werkoverleg van tevoren vastgestelde agenda's?

10. Kent dit werkoverleg een schriftelijk verslag?

Om eventueel bestaande discrepanties tussen deze items te analyseren zijn allereerst per vergelijkbaar paar items een tweetal analyses gedaan: een t-test voor gemiddelden en een Pearson correlatie-analyse (6.3.). Vervolgens $z a l$ de correlatie-matrix van alle items tussen en binnen beoordelaars geanalyseerd worden $(6.4$.$) .$

6.3. Analyse van de discrepantie-items

6.3.1. Analyse van de discrepantie-items management-personeelszaken

6.3.1.1. De resultaten

In tabe1 6.2. zijn de parsgewijze vergelijkingen van de discrepantie-items weergegeven.

Tabel 6.2. Correlatie en T-test betreffende discrepantie-1tems management versus personeelszaken.

discrepantie-item
materıële arbeidsomstandigheden
Immateriële arbeidsomstandigheden meet- en registratlesystemen $\mathbf{r}$ T-waarde

$\begin{array}{ll}.63 * * * & 0.04 \\ .48 * * * & 1.36 \\ .57 * * * & 0.70\end{array}$

$\mathrm{N}=42$

$* * *: p \leqslant 0.01$ 
Zoals uit deze tabel blifkt zijn de beoordelingen van management en personeelszaken ten aanzien van deze items zeer consistent. Er 18 dus sprake van een hoge validiteit; hun oordelen komen onderling sterk overeen.

6.3.1.2. Interpretatie van de verschillen tussen beoordelingen tussen het management en het hoofd personeelszaken

Gegeven de grote mate van overeenstemming tussen deze beide beoordelaars, ten aanzlen van de feitelifke gegevens kan geconcludeerd worden dat deze belde groepen veelal als een gelijke informatiebron gebruikt kunnen worden. Daarbij dient overigens in aanmerking genomen te worden dat, -zoals uft het vorige hoofdstuk bleek- de totale mate van overeenstemming tussen deze belde beoordelaars wel belnvloed wordt door diverse organisatiekenmerken (zie 5.2.).

6.3.2. Analyse van de discrepantie-1tems management versus personeelsvertegenwoordiging

6.3.2.1. De resultaten

In tabe1 6.3. zifn de resultaten van de correlatie-analyse en de T-test (tweezijdig getoetst) weergegeven ten aanzien van de discrepantie-items management versus personeelsvertegenwoordiging. 
Tabe1 6.3. Correlatie en T-test betreffende de discrepantie-items management en personeelsvertegenwoordiging (tweezijdig getoetst).

\begin{tabular}{|lcc|}
\hline discrepantie-items & $r$ & T-waarde \\
\hline materiële arbeidsomstandigheden & $.58 * * *$ & $-4.12 * * *$ \\
immateriële arbeidsomstandigheden & $.21^{*}$ & $-2.37 * *$ \\
meet- en registratiesystemen & $.26 *$ & 1.02 \\
werktijdverkorting & $.61 * * *$ & $1.78 *$ \\
natuurlijke afvloeilng & $.58 * * *$ & 0.87 \\
ontslagen & -.06 & $1.67 *$ \\
reorganisatie & .03 & -1.00 \\
automatisering & .18 & -1.00 \\
mechanisering & $.55 * *$ & $1.70 *$ \\
verhoging arbeidstempo & .06 & 1.43 \\
functieverruiming & $.48 * * *$ & -1.35 \\
functieverenging & -.03 & -0.57 \\
\hline
\end{tabular}

$$
\begin{aligned}
& \mathrm{N} \quad=42 \\
& * * *: \mathrm{p} \leqslant 0.01 \\
& * * \quad: 0.01<\mathrm{p}<0.05 \\
& * \quad: 0.05<\mathrm{p} \leqslant 0.10
\end{aligned}
$$

Uit deze tabel komt een zeer wisselend beeld te voorschijn ten aanzien $v$ an de consistentie tussen de beoordelingen. Slechts zes van de twaalf correlaties hangen signiflcant samen. Opvallend is de grote mate van overeenkomst in antwoordpatronen ten aanzien $v$ an de beoordeling $v$ an de hinder van materiële arbeldsomstandigheden en het gebrek aan overeenstemming in de beoordeling van de hinder veroorzaakt door immateriële arbeldsomstandigheden. In beide gevallen vindt de personeelsvertegenwoordiging dat meer hinder wordt ondervonden van de omstandigheden waaronder gewerkt moet worden. Het ontbreken van een overeenkomst in beider antwoordpatronen bij de immateriële arbeldsomstand1gheden kan duiden op een gebrekkige overeenstemming over dit begrip als zodanig (convergente validitelt) of op een minder goede kennis van deze omstandigheden. De immateriële arbeidsomstandigheden zifn moel11jker waarneembaar dan de materlële. Management en personeelsvertegenwoordiging hanteren verschillende criteria ter beoordeling van de arbeidsomstandigheden.

Eenzelfde soort bevinding geldt voor de items: werktijdverkorting, natuurlijke afvloeilng en gedwongen ontslagen. Ook ten 
aanzien wan deze items wordt geen consistent overeenkomend afwijkend antwoordpatroon tussen de belde beoordelaars geconstateerd. De vragen naar het voorgekomen $z 1 j n$ van werkt1jdverkorting en natuurlijke afvloeling blifken hoge correlaties op te leveren en het antwoordpatroon blijkt over organlsaties, tussen belde beoordelaars, overeen te komen. Dit geldt echter nlet voor het woorgekomen zijn van gedwongen ontslagen. De personeelsvertegenwoord 1g1ng constateert bovendien, dat werktijdverkorting en gedwongen ontsiagen vaker voorgekomen zijn dan het management aangeeft. Kennelijk worden tussen beoordelaars verschillende maatstaven gehanteerd voor gedwongen ontslagen en werkt1jdverkorting. Ten aanzien van het vo6rkomen van gedwongen ontslagen blijkt bovendien geen overeensteming over de mate van voorkomen. De vragen betreffende reorganisaties, automatisering en mechanisering vertonen een uiteenlopend beeld; op het gebled van mechanisering blijken grote overeenkomsten in beoordelingspatronen te bestaan tussen management en personeelsvertegenwoordiging, zij het dat de personeelsvertegenwoordiging oordeelt dat er meer activiteiten zijn geweest. Ten aanzien van het voorgekomen zijn van automatiserling en reorganisaties blijkt geen enkele overeenkomst tussen beoordelaars te bestaan. Ook hier kan dit verschil ontstaan zijn door verschillen in opvattingen over de inhoud van de concepten 'reorganisatie' en 'automatisering' (gebrek aan convergente vallidteit) of door een andere betekenisverlening van gebeurtenissen in organisaties.

Bij de laatste groep items, die een weergave vormen van de effecten van reorganisaties, automatisering en dergelijke op de inhoud van de arbeld, zij geconstateerd dat uitsluitend over het positieve effect, verruiming van functles, een gelljkluidend oordeel bestat.

6.3.2.2. Interpretatie van de bevindingen

Het total aan geconstateerde overeenkomsten en verschillen le1dt tot de volgende globale interpretaties:

a. Arbeldsomstandigheden worden in alle gevallen door de personeelsvertegenwoordiging als meer hinderlijk beoordeeld. Zowel ten aanzien van het vó́rkomen van hinder ten gevolge van $1 \mathrm{~m}-$ materlële als van materiële arbeidsomstandigheden blifkt tussen management en personeelsvertegenwoordiging een gelljk patroon in beoordelingen te bestaan, $z i j$ het met een ruim verschil in sterkte van de samenhang tussen de betreffende items onderling. Dit kan geweten worden aan verschil in ver- 
trouwdheid met de bestaande informatie en/of an hantering $v a n$ andere referentiekaders.

b. Ten aanzien van veranderingen in de bedrijfsorganisatie en de effecten daarvan blijkt het management positiever te oordelen dan de personeelsvertegenwoordiging. Ten aanzien van negatieve effecten ontbreekt overeensteming. De verklaring $11 \mathrm{jkt}$ gezocht te moeten worden in de verschillende posities in de organisatie, waarbif voor het management de doeleinden het meest belangrijk $z i j n$, terwijl voor de personeelsvertegenwoordiging de effecten primair is.

c. Ten aanzien van de items betreffende de personeelsformatie wordt geconstateerd dat slechts daar waar sprake is van collectieve aanvigen, zoals arbeidstifdverkorting, een hoge mate van overeenkomst is, terwijl bif de meer ad hoc of sluipende processen, zoals: (incidentele) ontslagen en natuurlifke afvloeiIng de overeenkomst ontbreekt. Dit kan betekenen dat de personeelsvertegenwoordiging vaker dergelljk ad hoc beleld als systematisch beleid beoordeelt, en/of dat het management julst dergelijke aspecten als incidenteel en niet als structureel beschouwt.

Ook ter verklaring van dit fenomeen lifkt een doorslaggevende rol te moeten worden toegekend. Een ruime personeelsbezetting heeft voor het personeel een positieve (geringere werklast) en voor het management een negatieve waarde (grotere loonkosten). De angst voor de elgen werkgelegenheld zal blf de personeelsvertegenwoordiging eerder leiden tot de beoordeling van Inc1dentele personeelsbeperkende matregelen als een doelbewuste en structurele aanpassing van de personeelsbezetting.

d. De gevonden verschillen blijken niet verklaard te kunnen worden uit systematische meetfouten of blas. In een dergelijk geval worden niet alleen ten aanzien van de beoordeling van soortgelijke items geheel andere stat1st1sche verbanden gevonden, maar is ook met verschil tussen de hoge intercorrelatie tusisen de beoordelingen ten anzien van de hinder van de materiële arbeidsomstand 1 gheden en het ontbreken van een dergelijke correlatie tussen de beoordelingen van de hinder van de Immateriële arbeldsomstandigheden onverk1aarbar. Evenmin kunnen dan de verschillende samenhangen ten aanzien van functieverruiming, -verengling en verhoging van arbeldstempo verklaard worden. 
e. Slechts zes van de twaalf discrepantie-items leveren een silgnificante correlatle op; de informatie verkregen via de personeelsvertegenwoordiging vertoont slechts een beperkte overeenkomst met de informatie vanuit het management. Informatie, welke ultsluitend via een van de beide groepen in de organisatie verkregen is, dient met grote voorzichtigheid gehanteerd te worden gezien het risico van misinterpretaties. Zo kan verschil in opvattingen over het voorkomen van ontslag of over gevolgen van taakveranderingen op de taakinhoud repercussies hebben op de manier waarop nieuwe plannen (reorganisaties, werkstructurering en dergelijke) door het personeel ontvangen worden en daarmee op de mate $v a n$ motivatie tot medewerking van $1 . c$. de personeelsvertegenwoordiging aan dergelifke veranderingen binnen de arbeldsorganisatie.

6.3.3. Analyse van de discrepantie-1tems hoofd personeelszaken versus personeelsvertegenwoordiging

6.3.3.1. Analyse-resultaten

In tabel 6.4. zijn de resultaten van de correlatie-analyse en de T-test weergegeven van de discrepanties tussen de beoordelingen, ten aanzien van een aantal organisatiekenmerken, van het hoofd personeelszaken en de personeelsvertegenwoordiging. 
Tabel 6.4. Correlatie en T-test over de discrepantie-items hoofd personeelszaken en personeelsvertegenwoordiging (tweezijdig getoetst).

\begin{tabular}{|c|c|c|}
\hline Item & $\mathbf{r}$ & T-waarde \\
\hline $\begin{array}{l}\text { hinder materiële arbeldsomstandigheden } \\
\text { hinder immateriële arbeldsomstandigheden } \\
\text { meet- en registratiesystemen } \\
\text { beoordelingssysteem } \\
\text { personeelsbezetting } 1977 \\
\text { personeelsbezetting } 1980 \\
\text { onvervulbare vacatures } \\
\text { werkoverleg } \\
\text { agenda } \\
\text { schriftelijk verslag }\end{array}$ & $\begin{array}{l}.58 * * * \\
.31 * * \\
.46 * * * \\
.59 * * * \\
.28 * \\
.29 * \\
.06 \\
.65 * * * \\
.36 * * \\
.45^{*}\end{array}$ & $\begin{array}{l}-3.91 * * * \\
-1.37 \\
0.49 \\
-2.78 * * * \\
-0.18 \\
2.55 * * * \\
0.87 \\
-1.09 \\
0.74 \\
0.63\end{array}$ \\
\hline $\begin{array}{l}\mathrm{N} \quad=42 \\
* * *: \mathrm{P} \leqslant 0.01 \\
* * \quad: 0.01<\mathrm{p} \leqslant 0.05 \\
* \quad: 0.05<\mathrm{p} \leqslant 0.10\end{array}$ & & \\
\hline
\end{tabular}

Op éen na vertonen alle items een significante correlatie. Het patroon in beantwoording op deze verschillende vragen blijkt derhalve over de aan het onderzoek deelnemende organisaties gelijk. Dit blijkt alleen nlet te gelden voor het 1 tem waarin gevraagd wordt naar onvervulbare vacatures; bovendien is bij dit 1 tem evenmin sprake van een systematisch verschil in gemiddelden. Geconstateerd moet worden dat dit concept "onvervulbare vacatures" verschillende invullingen toelaat.

Overigens vertonen een drietal 1 tems een systematisch verschil in beoordeling, ondanks een gelijk antwoordpatroon. Het hoofd personeelszaken vindt vaker dan de personeelsvertegenwoordiging dat:

- de materiële arbeldsomstandigheden minder hinderlijk $z 1 \mathrm{jn}$,

- personeelsleden meer systematisch beoordeeld worden,

- het personeelsbestand eerder an de te krappe kant 1 s dan aan de te ruime kant.

6.3.3.2. Interpretatie van de bevindingen

a. Materiële arbeldsomstandigheden worden als meer hinderi1jk voor de werknemers beoordeeld door de personeelsvertegenwoordiging dan dat door het hoofd personeelszaken gebeurt. Ten 
aanzlen van Imateriële arbeldsomstandigheden is dit verschil niet significant. In vergelljking met de discrepanties tussen management en personeelsvertegenwoordiging lijkt dit erop te wijzen dat bif personeelszaken een beter inzlcht in de immaterielle arbeldsomstandigheden bestaat. Deze indruk wordt bevestigd door sterkere overeenkomst in het antwoordpatroon tussen het hoofd personeelszaken en personeelsvertegenwoordiging ten aanzien $v$ an de beoordeling van de hinder van immateriéle arbeldsomstandigheden dan die tussen het management en de personeelsvertegenwoordiging.

b. De invioed van de positie van de beoordelaar in de arbeidsorganisatie blijkt uit het grote verschil in de mate waarin de belde categorleèn beoordelaars veronderstellen dat binnen de arbeldsorganisatie een systematisch personeelsbeoordelingssysteem gehanteerd wordt. Ondanks een gelljk antwoordpatroon ontstaat ult de beoordeling $v$ an het hoofd personeelszaken een veel positiever beeld over de mate warin een systeem gehanteerd wordt dan dat bij de personeelsvertegenwoordiging het geval is.

c. Dit effect van de positie van de beoordelaar in de organisatie $11 j \mathrm{kt}$ ook verantwoordelijk voor het ontbreken van enige overeenkomst ten aanzien van het v66rkomen van onvervulbare vacatures. Voor personeelszaken betreffen dit vacatures, waar $z i j$ zeer 1 ang mee geconfronteerd worden, terwijl onvervulbare vacatures voor de personeelsvertegenwoordiging eerder een inschatting is op basis van de ervaring dat bepalde functies niet of zeer traag worden ingevuld. De directe confrontatie van de belde beoordelaars met onvervulde vacatures $11 \mathrm{jkt}$ de beoordeling over het vórkkomen ervan te bepalen. B1j deze constatering sluit de verrassende bevinding aan, dat het personeelsbestand door personeelszaken eerder als te krap ervaren wordt dan dat dit geschledt door de personeelsvertegenwoordiging. Ook dit lijkt een 'positie'-effect, daar over de organisaties heen wel gelijk geoordeeld wordt (hoge correlatie). Personeelszaken zal meer geconfronteerd worden met klachten over personeelskrapte op bepaalde afdelingen dan met klachten over de 'ruimheid" in personeel. Deze ervar1ng leldt dus vaker tot de constatering dat het personeelsbestand aan de krappe kant is. 
d. Ten aanzien van verschil in overeenstemming tussen beoordelingen van personeelszaken en personeelsvertegenwoordiging kan geen sprake $z i j n$ van een consistent statistisch effect, $0 . a$. gezien de grote mate $v a n$ overeenkomst in gemiddelden bij de beoordeling van het personeelsbestand in 1977 en het ontbreken ervan bij diezelfde beoordeling over 1980 .

e. Bij organisatieonderzoek, over een aantal organisaties heen, lijken deze bevindingen uit te wijzen dat vrij goed gebruik gemaakt $k$ an worden $v a n$ de gegevens verkregen middels personeelszaken. Echter ten aanzien van uitspraken binnen de organisatie bestaan er verschillen tussen de beoordelingen van de verschillende organisatiekenmerken. Deze verschillen 11 jken groter naarmate de betrokkenheid van personeelszaken bij deze kenmerken groter wordt.

6.4 .

De Multitrait-Multimethod-Matrix

Alvorens over te gaan tot een gedetallleerde bespreking $v$ an de afzonderlijke MTMM-matrices $z a l$ een totaalbeeld gepresenteerd worden, waaruit enkele algemene tendensen afgeleid zullen worden. In tabel 6.5. zullen enkele gegevens uft de volgende matrices worden gepresenteerd; voor de volledige matrices wordt verwezen naar de bijlagen bij dit hoofdstuk. Aangegeven zal worden welk deel van de correlaties significant $(p \leqslant .10)$ is en tevens zal de mediaanwaarde van de correlaties weergegeven worden. 
Tabe1 6.5. Enkele overall kenmerken van de MTM-matrices.

\begin{tabular}{|c|c|c|c|}
\hline $\begin{array}{l}\text { Aard van de } \\
\text { correlaties }\end{array}$ & Beoordel aras & Mediaan & $\begin{array}{l}\text { Percentage } \\
\text { significante } \\
\text { correlaties }\end{array}$ \\
\hline $\begin{array}{l}\text { Interrater } \\
\text { convergente } \\
\text { correlaties }\end{array}$ & $\begin{array}{l}\text { management - p.z. } \\
\text { management - pers.vert. } \\
\text { pers.zaken - pers.vert. }\end{array}$ & $\begin{array}{l}.57 * * * \\
.24 * \\
.41 * * *\end{array}$ & $\begin{array}{r}100 \% \\
58 \% \\
90 \%\end{array}$ \\
\hline $\begin{array}{l}\text { Intrarater } \\
\text { correlaties }\end{array}$ & $\begin{array}{l}\text { management - p.z.1tems } \\
\text { management - p.v. 1tems } \\
\text { pers.zaken - man. 1tems } \\
\text { pers.zaken - p.v. 1tems } \\
\text { pers.vert. - man. 1tems } \\
\text { pers.vert. - p.z. 1tems }\end{array}$ & $\begin{array}{r}-.10 \\
-.01 \\
.19 \\
.07 \\
.08 \\
-.04\end{array}$ & $\begin{array}{l}33 \% \\
22 \% \\
67 \% \\
40 \% \\
24 \% \\
40 \%\end{array}$ \\
\hline $\begin{array}{l}\text { Interrater } \\
\text { correlaties } \\
\text { (verschil- } \\
\text { lende } 1 \text { tems) }\end{array}$ & $\begin{array}{l}\text { management - p.z. } \\
\text { management - pers.vert. } \\
\text { pers.zaken - pers.vert. }\end{array}$ & $\begin{array}{r}-.14 \\
.03 \\
.03\end{array}$ & $\begin{array}{l}67 \% \\
21 \% \\
34 \%\end{array}$ \\
\hline
\end{tabular}

Deze tabel is opgedeeld in drle groepen van correlaties:

* correlaties tussen eenzelfde ttem over verschillende beoordelaars (Interbeoordelaar convergente correlaties)

* correlaties tussen verschillende items bij eenzelfde beoordelaar (intra-beoordelaar correlaties)

* correlaties tussen verschillende ltens over verschillende beoordelaars (Interbeoordelaar correlaties)

Uit tabel 6.5. wordt duldelljk dat de correlaties tussen dezelfde 1 tems over verschillende categorieën beoordelaars zowel vaker significant zijn, als een hogere mediaanwaarde hebben dan de correlaties ult de belde andere groepen. Geen duldelijke verschillen bestaan er tussen de overige interbeoordelaars correlaties en de Intra-beoordelaars correlaties.

Dit overaicht leidt tot de conclusie dat de convergente validiteit van de gebruikte 1 tems in hun algemeenheid goed te noemen 1s. De medianwaarden en het percentage significante correlaties geven ook aanleiding om te concluderen dat de beoordelingen van management en personeelszaken en van personeelszaken en personeelsvertegenwoordiging meer met elkaar overeenkomen dan de 
beoordelingen van management en de personeelsvertegenwoordiging. Dit kan gezien worden als een positie-effect: Naarmate posities verder uit elkaar liggen wordt de overeensteming over kenmerken $v$ an de werkorganisatie geringer.

Nu zal overgegaan worden naar een gedetailleerde bespreking, waarbij ook Ingegaan zal worden op de vraag op welke items dan vooral overeensteming of verschillen gevonden worden. Tevens zal dan ingegaan worden op de vraag bij welke 1tems sprake is van convergente of discriminante validiteit.

Zoals eerder gesteld (hoofdstuk 3) is namelijk middels deze matrices te analyseren of:

- er sprake is van een convergente validiteit van de concepten in de items,

- er sprake is van discriminante validiteit van de concepten tussen items,

- er binnen de matrices een samenhang tussen de items geconstateerd kan worden, die meer inzicht geeft in de perceptle van de beoordel aars op de verschillende organisatiekenmerken.

6.4.1. De MTMM-matrix tussen management en hoofd personeelszaken

$6 \cdot 4 \cdot 1 \cdot 1$. Resultaten

De in paragraaf 6.3.1. beschreven items leveren de volgende MTMM-matrix (tabel 6.5.) op. 
Tabe1 6.5. De MTMM-matrix van de items beoordeeld door management en personeelszaken.

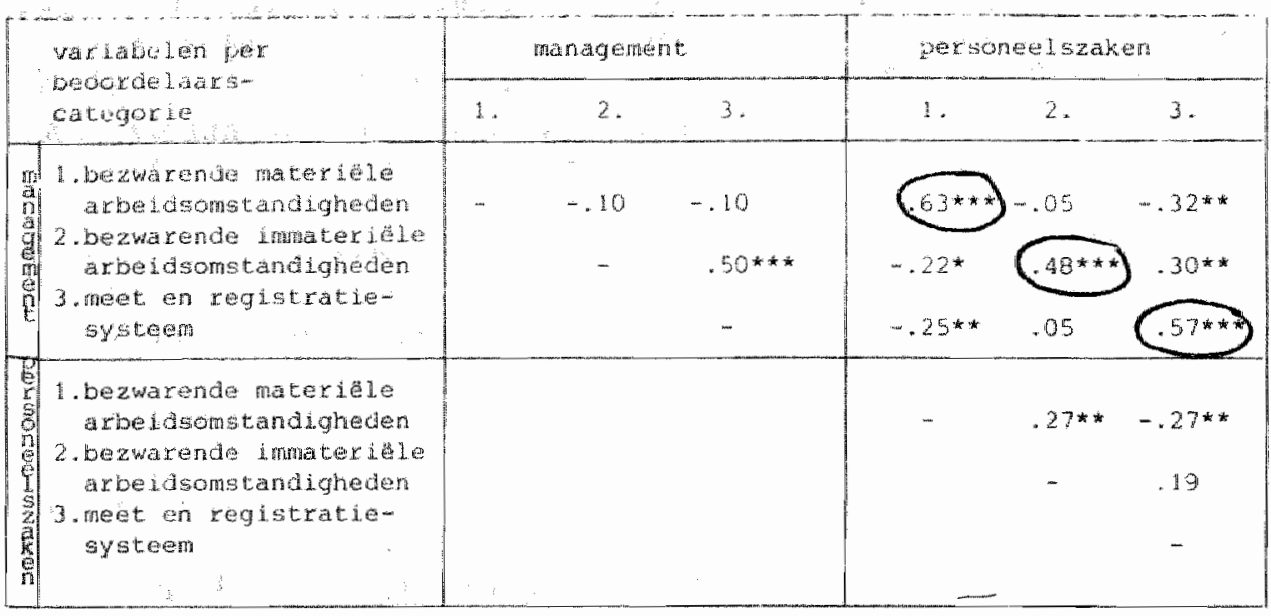

$$
\begin{aligned}
M= & 42 \\
* * & =0 \leqslant 0.01 \\
* & =0.01 \leqslant p<0.05 \\
& =0.05 \leqslant p<0.10
\end{aligned}
$$

De drie correlaties die betrekking hebben op een beoordeling door verschillende beoordelaars van hetzelfde item zijn omringd. Van convergente validiteit is sprake indien de correlaties signiflcant verschillen van nul. Uit de gepresenteerde correlatiematrix blijkt aan deze voorwaarde voldaan te $z 1 \mathrm{jn}$.

Eveneens 1 s er sprake van een discriminante validiteit, daar de betreffende correlatle coëfficlënten aanmerkelijk hoger $z i j n$ dan de correlatie coëfficiënten van deze items met andere items, zowel bij dezelfde als bij de andere beoordelaar. Bovendien vertoont het patroon van interrelaties tussen de items over de beoordelaars min of meer overeenkomstige relaties als de items binnen een beoordelaar. 
6.4.1.2. Interpretatie van de MTMM-matr1x: management versus hoofd personeelszaken

De betreffende items blijken een eenduldig concept te meten, waarbij de meting onafhankelijk is van de beoordelaar. In de verschillende beoordelaars-matrices zijn de negatleve correlaties tussen meetapparatuur en de materiële werkinconveniënten begrijpelijk. Naarmate er meer inconveniënten zijn, zal de kans groter zijn dat er meer meetapparatuur is. Minder logisch is de positieve correlatie tussen het voorkomen van meetapparatuur en immateriële inconveniënten. De vraag blifft echter waarom bij meer Immateriële werkinconvenıënten minder meetapparatuur aanwe$\mathrm{zIg}$ is. Deze vraag wordt immers slechts ten dele verklaard door de licht negatieve relatie tussen de beide vormen van hinderlijke arbeldsomstandigheden bij het management en tussen de beoordeling $v$ an deze immateriële omstandigheden beoordeeld door het management met de materiële omstandigheden beoordeeld door het hoofd personeelszaken.

6.4.2. De MTMM-matrix tussen management en personeelsvertegenwoordiging

6.4.2.1. Resultaten

De in paragraaf 6.3.2. beschreven items leveren de volgende MTMM-matrix op. 


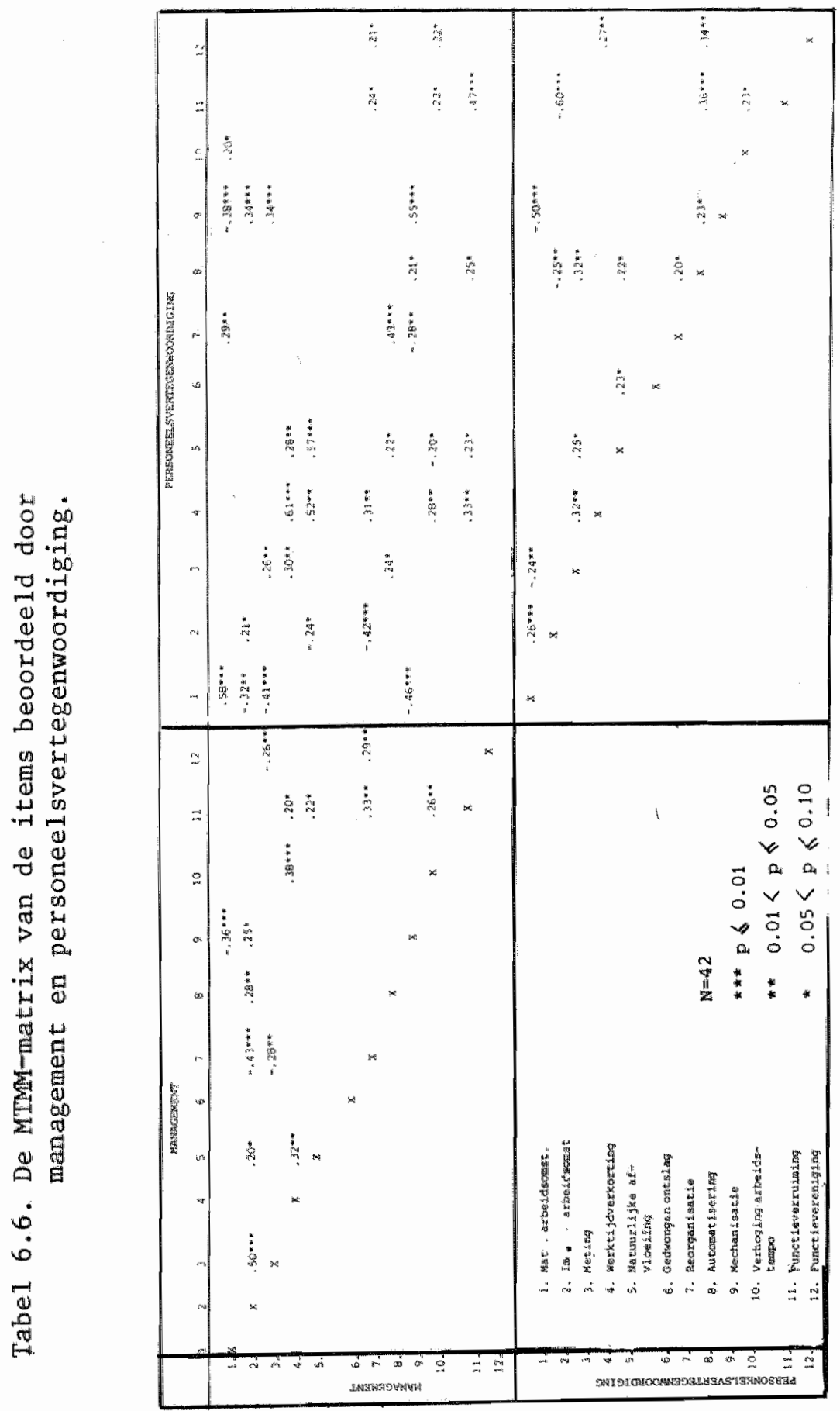


Ook hier zijn uitsluitend de significante correlaties weergegeven; voor een totaal-overzicht zle bijlage 6. Ten aanzien van zeven $v a n$ de twaalf items kunnen we spreken van een voldoende grote convergente validitelt (correlaties tussen gelijke items over verschillende beoordelaars (omringd) zifn significant. Aan de eerste voorwaarde voor een voldoende discriminante validiteit voldoen slechts vier van de twalf items.

Over de tweede els ten aanzien van het patroon van interrelaties tussen de observatoren is op basis van face-value weinig te zeggen.

Items die duidelijk een concept meten en zich in de meting $v a n$ andere concepten onderscheiden $\mathrm{zijn}$ :

- hinder van materiële arbeldsomstandigheden,

- voorkomen van werktijdverkorting,

- voorkomen van natuurlijke afvloeilng,

- ontwikkelingen op het gebled van mechanlsering.

Uitsluitend een hoge convergente validiteit bezaten de volgende concepten:

- hinder van immateriële arbeldsomstandigheden,

- aanwezigheid van meet- en registratiesystemen,

- functieverruiming door taakverandering.

Geen convergente validiteit werd gevonden bij de items:

- voorkomen van ontslagen,

- voorkomen van reorganisaties,

- ontwikkeling op het gebled van automatisering,

- verhoging arbeidstempo door taakverandering,

- functieverenging.

6.4.2.2. Interpretatie van de MTMM-matrix: management versus personeel svertegenwoordiging

Eenzelfde soort 1tems kan klaarblijkel1jk zowel een goede, als een onvoldoende, convergente validiteit vertonen. Dit $11 \mathrm{jkt}$ mede afhankelijk te $z \mathbb{1 j n}$ van de mate warin een gebeurtenis, fenomeen als zodanig en de mate waarin officiëel bepalde zaken moeten worden aangevraagd (werkt1jdverkorting, toepassing VUT regeling). Negatleve aspecten van de organisatie, zoals: verhoging van arbeldstempo, functieverenging, ontslagen, blijken tot een geringere mate van overeensteming te leiden dan positieve (o.a. functieverruiming), hetgeen een effect zou kunnen zijn van het verschil in positie van de beoordelars. 
Gegeven de correlatiestructur blijkt het oordeel van de personeelsvertegenwoordiging ten aanzien $v$ an het voorkomen $v$ an automatisering samen te hangen met zeven van de elf resterende 1 tems, terwijl dit 1 tem b1j het management slechts samengaat met een enkel item. Het voorkomen van automat1sering blijkt een zeer centrale rol in te nemen in de perceptie van de personeelsvertegenwoordiging van een aantal organisatiekenmerken. Met het al dan nlet voorkomen van automatisering is voor hen tegelijkertijd een groot aantal andere organisatieaspecten verbonden.

Bij het management blijkt de variabele "hinder van immateriële arbeidsomstandigheden" de meer centrale plaats in te nemen (signiflcante correlatie met 5 van de 11 items).

6.4.3. De MTMM-matr1x tussen het hoofd personeelszaken en de personeelsvertegenwoordiging

6.4.3.1. Resultaten

De in paragraaf 6.3.3. beschreven items leveren de volgende MTMM-matrix op. 

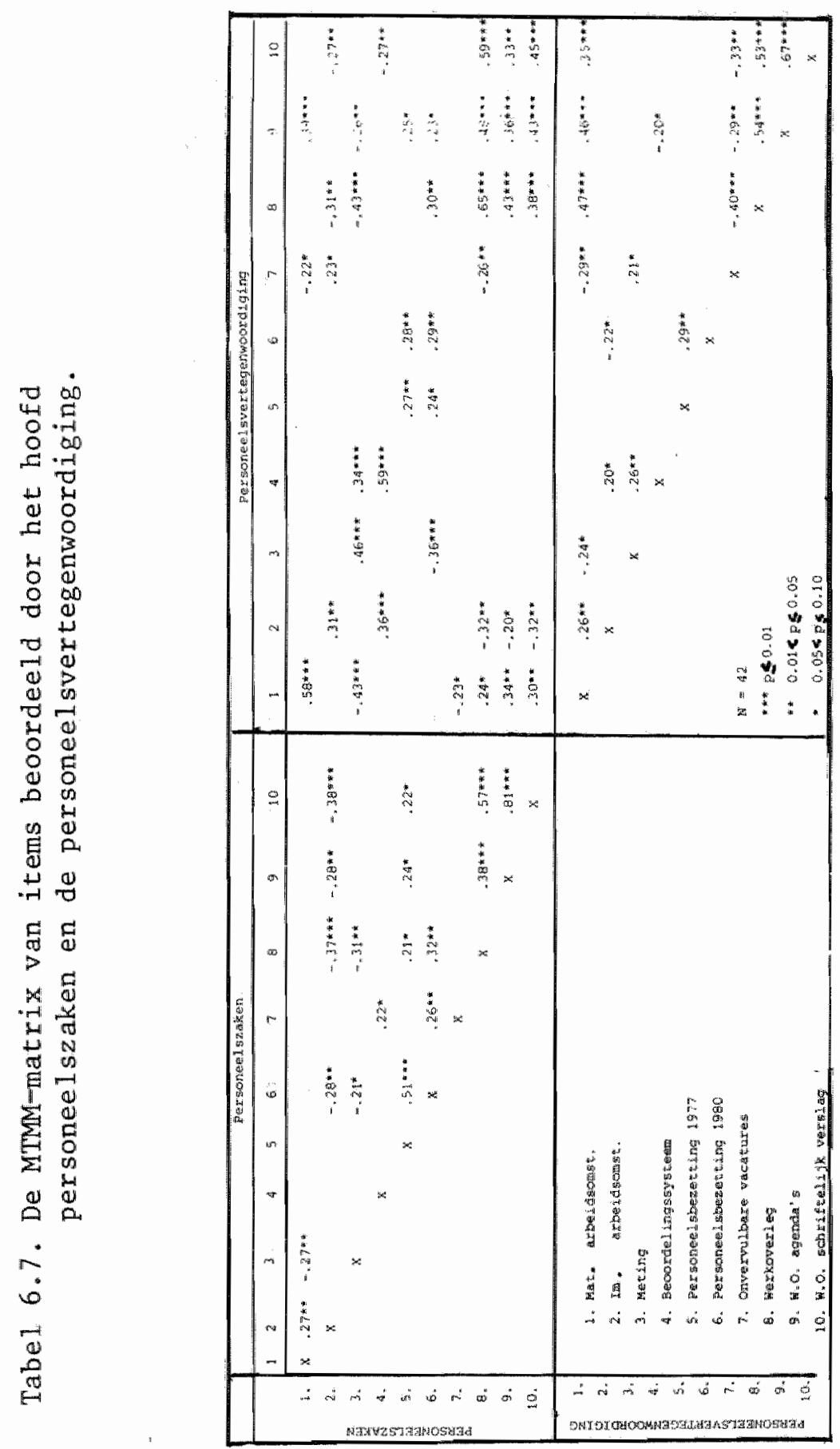
De volledige tabel is weergegeven in bijlage 7 . Zoals uit tabel 6.7. b11jkt hebben negen van de tien items een voldoende convergente vallditeit. De veronderstelling is derhalve gewettigd dat er eenduidigheld bestat over alle in de 1 tems genoemde concepten, met ultzondering $v$ an de aanwe 1 gheld van onvervulde vacatures. Ten aanzien van dat 1 tem blijkt een voldoende convergente validiteit te ontbreken.

Aan de eerste els voor een voldoende discriminante validiteit wordt slechts door een viertal varlabelen voldaan, te weten:

- hinder van materielle arbeldsomstanidgheden,

- de aanwezigheld van meet- en reglstratlesystemen,

- het voorkomen van een personeelsbeoordelingssysteem,

- de aanwezigheid van een gestructureerd werkoverleg.

6.4.3.2. Interpretatie van de MTMM-matrix: hoofd personeelszaken versus personeelsvertegenwoordiging

De matrix in tabel 6.7. vertoont een betrouwbare consistente meting ten aanzlen van een groot aantal litems over de beide beoordelaars. Dit geldt met name wat betreft de organisatiekenmerken, die direct warneembare aspecten van de arbeid representeren, danwel de mate waarin bepalde vormen van gestructureerd overleg voorkomen. Ten aanzien van de interne structuur van de matrix is het opvallend, dat binnen de beoordelingen van het hoofd personeelszaken, de aanwezlgheid van werkoverleg samen blijkt te gaan met zes van de overige negen 1tems. De aanwezigheld van werkoverleg blijkt aldus mede gezien het sterk discriminerende karakter $v$ an dit item een kernfunctie te hebben in de beeldvorming van het hoofd personeelszaken over de arbeldsorganlsatie. Zo hangt diens perceptle van het werkoverleg sterk samen met diens opvatting over de mate van hinder van Immateriële arbeldsonstandigheden. Dit is begrijpelijk aangezien veel hinder van Immateriële arbeldsomstandigheden veelal slechts ontdekt zal kunnen worden in geregeld overleg met de verschillende afdelingen. Bovendien hangt werkoverleg ook samen met een rulmere personeelsbezetting en met het veelvuldiger aanwezig zijn van meet- en registratiesystemen. Een tweede varlabele, die met veel andere items blijkt samen te hangen, is de mate warin personeel hinder ondervindt van immaterielle arbeldsomstand $1 \mathrm{gheden.}$

Bij de personeelsvertegenwoordigling blijkt vooral de mate waarin het personeel geacht wordt hinder te ondervinden van slechte materiële werkomstandigheden samen te gaan met een relatief groot aantal andere items. 
6.5. Samenvatting van de analyse van de discrepantie-1tems

Bij de bepaling van de convergente validitelt van de betreffende kenmerken blijkt dat van de tweeëntwintig relevante, verschillende mogelijke itemcorrelaties zestien een voldoende convergente validiteit te bezitten. Blijkbaar kan een zeer groot deel van de organisatiekenmerken gezien het antwoordpatroon over organisaties heen bij slechts één beoordelaar gemeten worden. Hierbij moet wel in aanmerking worden genomen dat de mate van overeenstemming tussen personeelszaken en personeelsvertegenwoordiging groter blijkt, dan die tussen het management en de personeelsvertegenwoordiging.

Indien echter vanuit de beoordeling van de verschillende items conclusies getrokken worden ten aanzien van de interne structuur $v a n$ de arbeldsorganisatie kan niet volstaan worden met een beperkt aantal beoordelaars. Een sterke convergente en discriminerende validitelt blijkt namelijk niet te impliceren dat er geen verschillen kunnen bestaan in de mate waarin het betreffende kenmerk voorkomt of in de mate waarin men daarvan hinder ondervindt. Bovendien blijkt uit de correlatie-matrix dat bij de beoordeling van organisatiekenmerken de zwarte van de verschillende items over de beoordelaars niet gelijk is. Dit impliceert dat voor de ene beoordelaar de mate waarin automatisering voorkomt centraal staat, gezien de sterkte van de samenhang tussen die varlabele en andere variabelen, zoals hinderlijke immateriële arbeidsomstandigheden, natuurlijke afvloeilng, reorganisaties, mechanisering, functieverruiming, functieverenging. Dit in tegenstelling tot de grote verschillen binnen de verschillende beoordelaars matrices. Dit vormt we 1 een relevante bevinding ten anzien van activitelten, die gericht zijn op organisatieverandering. Dergelifke interventies zullen veelal vanuit dit kader beoordeeld worden. 


$$
-134-
$$


HOOFDSTUK 7. DISCREPANTIE BIJ DE BEOORDELING VAN DE ARBEIDSOMSTANDIGHEDENITEMS

\subsection{Inleiding}

Nadat in hoofdstuk 6 een antal algemene discrepantie-items met elkaar vergeleken zijn, zal de aandacht in dit hoofdstuk spec1fiek gericht worden op de arbeidsomstandighedenitems. Daarbij zal een uitgebreider aantal beoordelaars betrokken worden. Naast de beoordelingen van het management, hoofd personeelszaken en personeelsvertegenwoordiging zal ook de gemiddelde score geanalyseerd worden van de beoordelingen van het direct-uitvoerend personeel. Deze laatste beoordelingen zijn ontleend aan een studie naar opvattingen van werknemers, werkzaam bij de bedrijven, die deel hebben genomen aan het organisatieonderzoek.

Bij die organisaties is namelijk eveneens een onderzoek uitgevoerd onder een representatieve steekproef van de werknemers deze bedrijven. De betreffende scores zijn berekend op basis van de beoordelingen via interviews verkregen van werknemers, die tot het directe productiepersoneel behoren. Met deze uitbreiding van het data-materiaal ter analyse werd beoogd het inzicht te verkrijgen in de wijze waarop de gevonden discrepantie tot stand komt. Omdat in de oorspronkelijke studie in een enkel geval een ander indelingscriterium gehanteerd is, is het aantal organisaties warover vergelijkbare personeelsbeoordelingen bestaat veertig.

Eerst zullen de totaalscores, zoals deze in het vorige hoofdstuk $z i \mathrm{jn}$ gehanteerd, aan elkaar gerelateerd worden. Vervolgens is uft de 23 thems, op basis van een min of meer gelljkwaardige afsplegeling van de materlële en immateriële arbeidsomstandigheden, een breed scala van 15 items gekozen. Met deze 15 items zullen de verdere discrepantie-analyses per 1 tem uitgevoerd gaan worden. De belangrijkste statistische kenmerken van deze items zijn vermeld in bijlage 8 .

Voor de vergelijking tussen de beoordeling van het management, hoofd personeelszaken en de personeelsvertegenwoordiging en de gemiddelde werknemersscore gelden de volgende twee beperkingen: 1 . Bij de $\operatorname{vra}(a) g(e n)$ betreffende hinderlijke arbeldsomstandigheden is in plaats van de vraag, welk deel van het personeel hinder ondervindt van ...., zoals deze aan de drie eerst genoemde beoordelaars gesteld is (zie: 3.5.), is an de geinterviewde werknemers gevraagd: 'in hoeverre ondervindt $U$ 
hinder van...'. Indien de geinterviewde groep representatief is moet dit een vergelijkbare beoordeling opleveren.

2. Het aantal geinterviewde werknemers -uit de personeelscategorie direct-ultwoerend personeel- kan vooral in kleinere bedrijven erg gering zijn (het aantal geinterviewde werknemers uit deze categorie variëert van $I$ tot 49 , met een gemiddelde van 13,5$)$. Doordat de werknemers gevraagd is hun eigen oordee 1 uit te spreken is het mogelijk dat een vertekening in de gesommeerde beoordeling kan ontstaan, doordat binnen organisaties bepalde afdelingen over- of ondervertegenwoordigd $\mathrm{zljn}$. De richting van een eventuele vertekening dientengevolge kan zowel positief als negatlef $z i j n$, hetgeen zou kunnen resulteren in een geringer aantal significante correlaties.

7.2. De onderlinge relaties tussen de gesommeerde arbeidsomstandighedenscores

Per beoordelaar zijn een tweetal gesommeerde arbeidsomstandighedenscores berekend. Met name de scores ten aanzien van de hinder van materiële arbeldsomstandigheden blijken (verg. hoofdstuk 6) in bepalde gevallen sterk aan elkaar gerelateerd te zifn. In deze paragraaf zullen achtereenvolgens de samenhang (correlaties) tussen de gesommeerde arbeidsomstandighedenscores en de verschillen in absolute waarden van die scores beschouwd worden.

7.2.1. De samenhang tussen de gesommeerde materiële en immaterlële arbeidsomstandighedenscores

De correlaties tussen de verschillende gesommeerde beoordelingen van de mate van hinder die werknemers ondervinden van materiële en Immateriële arbeldsinconveniënten $z i j n$ weergegeven in tabel 7.1. 
Tabel 7.1. Correlatie-matrix van de gesommeerde arbeldsomstandighedenscores.

\begin{tabular}{|c|c|c|c|c|c|c|c|c|}
\hline \multirow{2}{*}{ 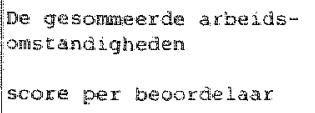 } & \multicolumn{2}{|c|}{ managenent } & \multicolumn{2}{|c|}{$\begin{array}{c}\text { hoofd perso- } \\
\text { need stanen }\end{array}$} & \multicolumn{2}{|c|}{$\begin{array}{l}\text { personealswer- } \\
\text { tegenwoordightng }\end{array}$} & \multicolumn{2}{|c|}{ 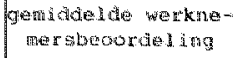 } \\
\hline & mat. & 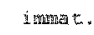 & mate. & imeat. & mat. & Lmanat. & mat. & inme. \\
\hline mat. & + & -.10 & $\begin{array}{l}-63^{3 * *} \\
-.22 *\end{array}$ & $\begin{array}{l}m .05 \\
.48^{* * * *}\end{array}$ & 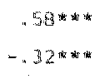 & $\begin{array}{l}.10 \\
.21 \mathrm{n}\end{array}$ & $\begin{array}{l}-60 \times 10 \times 1 \\
-.19\end{array}$ & $\begin{array}{l}.0 \% \\
.32 * * *\end{array}$ \\
\hline $\begin{array}{l}\text { Hooted perso- } \\
\text { neel szaken. }\end{array}$ & & & - & $.27 * *$ & $\begin{array}{l}.58 * * * \\
-.09\end{array}$ & $\begin{array}{l}-.03 \\
.31\end{array}$ & $\begin{array}{l}.74 * * * \\
.00\end{array}$ & $\begin{array}{l}.17 \\
.42 * * *\end{array}$ \\
\hline 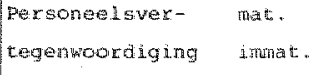 & & & & & - & $26^{* 1+1}$ &. $.5 \% k \cdots$ & $\begin{array}{l}.11 \\
.16\end{array}$ \\
\hline $\begin{array}{l}\text { Gemidjelde wexk- mat. } \\
\text { nemersbeorieling immat. }\end{array}$ & & & & & & & - & $.24 *$ \\
\hline
\end{tabular}

$$
\begin{array}{ll}
\mathrm{N} & =42 \\
* * * & : \mathrm{p} \leqslant 0.01 \\
* * & : 0.01<\mathrm{p} \leqslant 0.05 \\
* \quad: 0.05<\mathrm{p} \leqslant 0.10
\end{array}
$$

Omdat de relaties tussen de gesommeerde arbeldsomstandighedenscores van management, personeelszaken en personeel svertegenwoord1ging al in hoofdstuk 6 besproken $z i j n, z a l$ de aandacht vooral gericht worden op de relatie tussen deze variabelen en de gemiddelde beoordeling door de werknemerssteekproef.

De gesommeerde werknemersscore 'h1nder van materiële arbeidsomstandigheden' blijkt positief samen te hangen met die van de overlge 3 categorieën beoordelaars. Blijkbaar heeft deze gesommeerde beoordeling, onafhankelijk van de beoordelaar, over organisaties heen een ongeveer gelijk patroon. Bij de gemiddelde werknemersbeoordeling blijkt de gesommeerde materiële arbeldsomstandighedenvariabele geen enkele signiflcante relatie te vertonen met de 'hinder van 1mmateriële arbeldsomstandigheden'-variabele. Deze twee categorleën arbeldsomstandigheden blijken zich derhalve duidelijk te onderschelden, dat wil zeggen zij kunnen min of meer onafhankel1jk van elkaar variëren. Binnen elk van de beide categorieën variabelen "hinder van materiêle arbeidsomstandigheden' en 'hinder van immateriële arbeldsomstandigheden' blijken de variabelen onderling overigens hoog te 
correleren. Dit geldt echter nlet voor de relatie tussen de beoordeling van de lmmateriële arbeldsomstandigheden door leden van de personeelsvertegenwoordiging en die van de werknemers. De correlaties tussen de belde variabelen zijn aanmerkelijk minder hoog. Bovendien is opvallend dat met name de beoordeling van de immateriële arbeidsomstandigheden door het management negatief correleert wet de beoordeling van de materiële arbeidsomstandigheden door personeelszaken en personeelsvertegenwoordiging. Gezien de overige correlaties duidt dit erop dat het management deze twee variabelen nlet lijkt te beschouwen als behorend bij eenzelfde type werk, terwij1 voor personeelszaken, leden personeelsvertegenwoordiging en de werknemers deze belde omstandigheden blijken samen te kunnen gaan.

Wat betreft de 'hinder van immateriële arbeidsomstandigheden' vertoont de gesommeerde werknemersscore een significante samenhang met de scores op dezelfde varlabele bij het management en bij het hoofd personeelszaken. Dezelfde samenhang is echter niet significant ten aanzien van de beoordeling door leden van de personeelsvertegenwoordiging. Blijkbaar komen de gemiddelde beoordelingen over de immaterlële werkomgeving van de werknemers meer overeen met die van de 'staf'-afdelingen dan met de beoordelingen van hun eigen vertegenwoordigers in deze.

Deze frappante bevinding, waarop in hoofdstuk 8 wordt teruggekomen is $0 . a$. verklaarbaar vanult de veronderstelling dat een steekproef van werknemers meer de 'gemiddelde' beoordeling representeert en de personeelsvertegenwoordiging meer betrokken is op de 'slechtere' afdelingen, resulterend in onderlinge verschillen In percepties, doordat de personeelsvertegenwoordiging vanult haar belangenbehartigende taak meer gevoelig is voor negatieve signalen. Dat dit effect sterker is bij immateriële dan bif de materiele arbeidsomstandigheden kan verklaard worden, door het feit dat immateriêle arbeidsomstandigheden-1tems zich meer lenen voor verschillen in beoordeling, door het ontbreken van meer "objectieve matstaven".

7.2.2. Verschillen in gemiddelden tussen de gesommeerde materiële en immateriële arbeidsomstandighedenscores.

De verschillen tussen de gemiddelde scores op de gesommeerde arbeidsomstandighedenscores $\mathrm{z} 1 \mathrm{jn}$ weergegeven in tabe1 7.2 . 
Tabel 7.2. Verschillen tussen de gesommeerde arbeldsomstandighedenscores.

arbeidsomstand $1 \mathrm{gheden-}$ variabelen

verschil

tussen

beoordelaars gesommeerde arbeidsomstand1ghedenvariabelen

materiële arbeidsomstandigheden

T-waarde

genwoordiging

(1)

personeelszaken-personeels-

vertegenwoordiging

personeelszaken-werknemers-

score (1)

personeel svertegenwoordigingwerknemersscore (1)
Immaterièle arbeldsomst and 1 gheden T-waarde

0.0

$-4 \cdot 1 * * *$

$-2 \cdot 4 * *$

$-2.4 * *$

0.9

$-1.4$

$-1 \cdot 4$

$-2 \cdot 5 * *$

$2.0 *$

$\mathrm{N}=42$

1) $\mathbb{N}=40$

$* * *: p \leqslant 0.01$

$* * \quad: 0.01<\mathrm{p} \leqslant 0.05$

$\star \quad: 0.05<p \leqslant 0.10$

Uitgaande van de gemiddelde beoordelingen over de arbeidsomstandigheden bij dezelfde 40 bedrijven, vertonen de verschillen grafisch het beeld weergegeven in figuur 7 . 
F1guur 7. Graflsche weergave van de verschillen in beoordeling van de arbeidsomstandigheden.

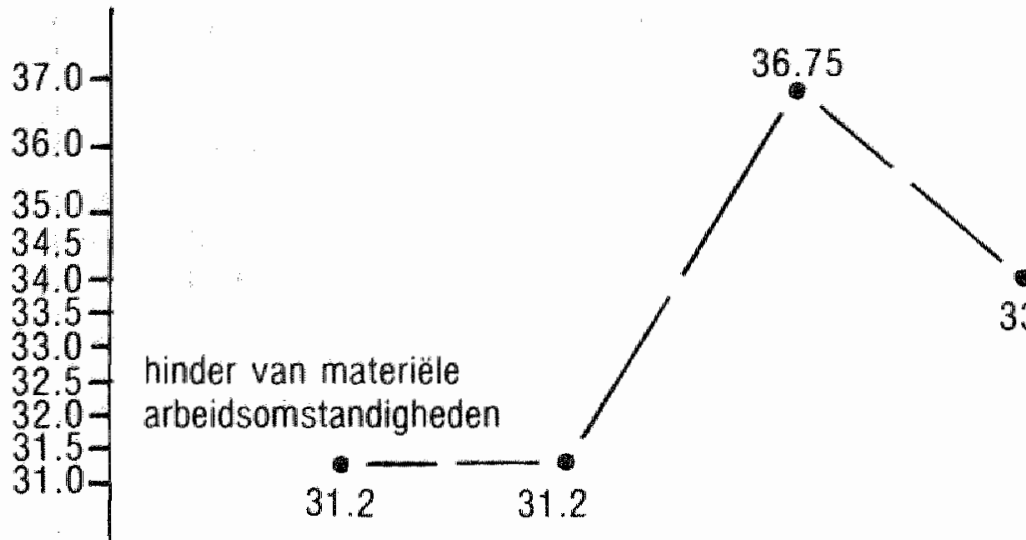

33.9

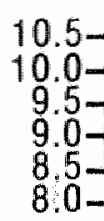

hinder van immateriële arbeidsomstandigheden

8.9

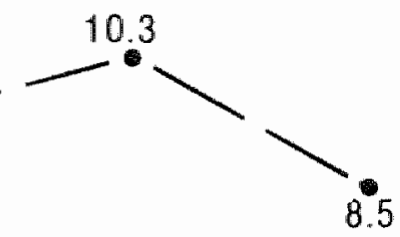

management personeelszaken personeelsverte- werknemersscore genwoordiging

U1t tabe1 7.2. en uit figuur 7 blijkt management en personeelszaken kwantitatief overeen te komen in hun perceptle van de hinder die werknemers ondervinden van de materlële arbeldsomstandigheden. Belde categorieën beoordelaars schatten de mate van hinder geringer in dan door de werknemers en personeelsvertegenwoordiging gedaan wordt. De personeelsvertegenwoordiging blifkt, overeenkomstig eerdere bevindingen, het meest negatieve oordeel te hebben ten aanzien van de mate waarin de arbeidsomstandigheden hinder veroorzaken.

De beoordelingen van de immateriêle arbeidsomstandigheden bieden een contrasterend beeld, gegeven de sterke overeenkomst in beoordeling tussen management en werknemers enerzijds en personeelszaken en personeelsvertegenwoordiging anderzijds. Deze laatste 
groep geeft in zijn algemeenheld een negatlever oordeel over de hinder veroorzaakt door de immateriële arbeidsomstandigheden in de eigen organisatie.

\subsection{Beoordeling van arbeidsomstandigheden en klaaggedrag}

Een gangbare veronderstelling is dat werknemers hun arbeidsomstandigheden slechter beoordelen narmate $z i j$ meer klaaggeneigd zijn. Dit zou impliceren dat de negatieve beoordeling van de arbeidsomstandigheden niet uitsluitend een weergave is van de objectieve situatie, maar tevens een effect van een klaaggedrag. Deze klaaggeneigdheid is gemeten middels de vragenlijst over ervaren gezondheid (VOEG) (Dirken, 1967). De VOEG, ontwikkeld als indicator voor de ervaren gezondheldstoestand, kan ook beschouwd worden als matstaf voor $\mathrm{klaaggeneigdheid} \mathrm{van} \mathrm{de} \mathrm{respondenten}$ (v.d. Zee, 1982).

Daar het onwaarschijnlijk is dat bij de selectie van werknemers in een arbeidsorganisatie klaaggenelgdheid een rol speelt zal de correlatie op organisatieniveau tussen de VOEG (een individueel diagnosticum) berekend op groepsniveau en de arbeidsomstandigheden minimal zijn. Philipsen (1970) geeft een analoge bevinding ten aanzien van de relatie tussen werkvoldoening en afwezlgheid wegens ziekte.

De mogelijkheid moet niet worden uitgesloten dat klaaggeneigdheid geen persoonlijkheidstrek is, maar situationeel bepaald en dat slechte arbeidsomstandigheden kunnen lelden tot een hogere klaaggenelgdheid. Dit zou dan de grondslag kunnen vormen voor een circulalr negatief beoordelingsproces.

In de eerder genoemde interviews onder werknemers van de aan dit onderzoek deelnemende organisaties is nast de mate waarin hinder ondervonden wordt van bepaalde arbeidsomstandigheden ook deze VOEG opgenomen. Omdat in dit hoofdstuk ultgegaan is van een tweetal gesommeerde arbeldsomstandighedenvariabelen, die per organisatie berekend zijn over de personeelscategorie direct-uitvoerend, mannelijk personeel is voor dezelfde personeelscategorie eveneens per organisatie een VOEG-score berekend. De relatie tussen de beide arbeidsomstandigheden variabelen en de VOEGscore is weergegeven in tabe1 7.3 . 
Tabe1 7.3. Gesomeerde arbeldsomstandighedenitems in relatie tot de VOEG-score.

\begin{tabular}{|lcc|}
\hline $\begin{array}{l}\text { Arbeldsomstan- } \\
\text { digheden }\end{array}$ & $\begin{array}{l}\text { Gemlddelde beoordeling } \\
\text { materiële hinderlijke } \\
\text { arbeldsomstandigheden }\end{array}$ & $\begin{array}{l}\text { Gemiddelde beoorde- } \\
\text { ling immateriële } \\
\text { arbeidsomstandigheden }\end{array}$ \\
VOEG & -.04 & -.04 \\
\hline VOEG-score
\end{tabular}

$\mathrm{N}=40$

Noch wat betreft de variabelen betreffende de hinderlijke materiele, noch wat betreft die betreffende immateriële arbeidsomstandigheden is enfge relatie aantoonbaar met de VoEG-score. Dit impliceert dat slechte arbeldsomstandigheden niet in een verhoging van de klaaggeneigdheld resulteren.

7.4. Arbeldsomstandigheden per item beschouwd

7.4.1. Verschillen en overeenkomsten tussen de beoordelingen van het management, het hoofd personeelszaken en leden van de personeelsvertegenwoordiging

Ondat de onderlinge vergelijkling van drieentwintig arbeidsomstandighedenttems omvangrijke en daardoor weinlg inzichtelijke matrices opleveren, $z i j n$ de in dit hoofdstuk vergeleken arbeidsomstandighedenitems teruggebracht tot die vijftien, waarvan verondersteld wordt dat $z i j$ een representatief beeld opleveren van het totaal van de arbeldsomstandighedenitems. De vergelijking zal plaatsulnden voor de in tabel 7.4 . vermelde items.

Bif de analyse van deze gegevens zal dezelfde procedure worden gehanteerd als beschreven in hoofdstuk 6 . De verschillen in gemiddelden en de correlatle-coëficlënten ten aanzien van gelifke items staan vermeld in tabel 7.4. (de p-warden zijn berekend middels tweezijdige toetsing). 
Tabel 7.4. Discrepantie-analyse van de arbeldsomstandigheden1 tems.

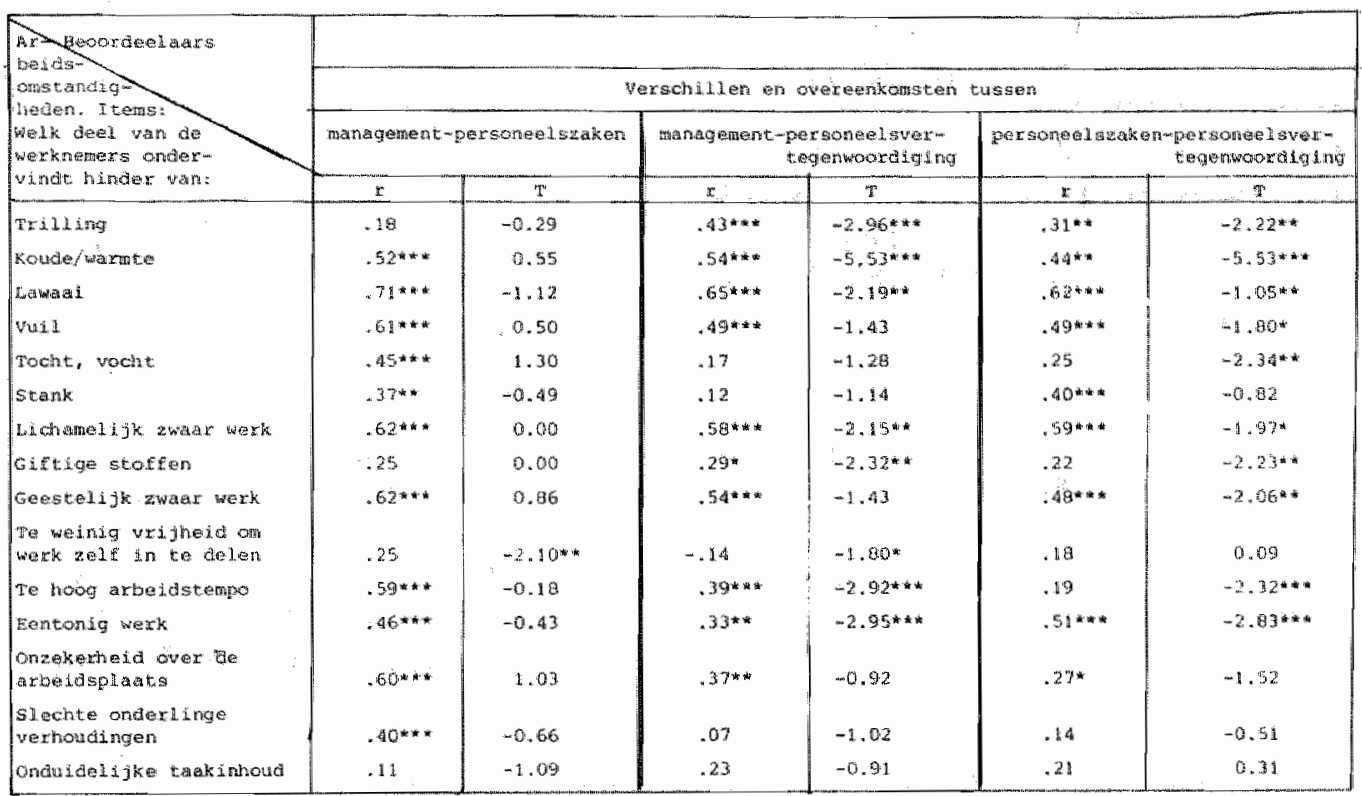

$* A 2$
$* \quad P \leqslant 0.01$
$* 0.01<p \leqslant 0.05$
$* \quad 0.05<p \leqslant 0.10$

Het beeld dat door de vergelijking van de gesommeerde scores is opgeroepen wordt in deze discrepantie-analyse bevestigd. Alleen blijkt dat de afwijkingen die gevonden worden bij de totaalscores (par. 7.2.) niet gelijkelijk over de verschillende items verdeeld zijn. 
7.4.1.1. De correlaties nader beschouwd

Opvallend is dat de beoordelingen van enkele items nauwelijks met elkaar samen blijken te hangen. Dit geldt vooral voor de 1 tems:

- te weinig vrijheid on het werk zelf in te delen,

- een onduidelifke taakinhoud;

en in mindere mate voor de items:

- tocht, vacht,

- giftige stoffen,

- slechte onderlinge verhoudingen.

Deze items lenen zich klaarblifkelijk voor verschillende interpretaties. De verschillende betekenissen die aan deze 1tems worden gehecht kunmen repercussies hebben op de 1nschatting van de mate waarin werknemers geacht worden hinder te ondervinden. Dit kan zowel het gevolg zijn van het ontbreken van een convergente validiteit, als een gebrek aan inzicht, in het veronderstelde hinderlifke effect van dergelljke arbeldsomstandigheden. De geringe overeenkomst ten aanzien van 'vocht, tocht' kan het gevolg zijn van het gebruik van twee concepten in eén item, hetgeen allicht leidt tot onduldelijkheid ten aanzien van het object van beoordeling: het meest erge, het gemiddelde van beiden of de beste situatie.

Een hoge mate van overeenstemming tussen de drie categorieën beoordelaars wordt vooral gevonden ten aanzien van items, die betrekking hebben op materielle aspecten van de arbeidsomstand $1 \mathrm{~g}-$ heden. Deze hoge mate van overeenstemming geldt voor de volgende items:

- koude/warmte.

- Lawai,

- vull,

- 11chame11jk zwaar werk,

- geestelljk zwaar werk,

- eentonig werk,

- onzekerheld over het voortbestaan van de arbeldsplaats.

De verschillen in correlaties tussen groepen beoordelaars geven de Indruk dat de overeenkomsten tussen de beoordelingen van het management en die van personeelszaken en personeelsvertegenwoordiging meer overeenstemmen dan de beoordelingen van personeelszaken en personeelsvertegenwoordiglng. Deze laatste oordelen blijken vooral een gebrek aan overeenstemming te vertonen op die items, dle gericht zijn op de organisatie van de arbeidsinhoud, zoals: 
- vrijheld om het werk zelf in te delen,

- arbeldstempo,

- onderlinge verhoudingen,

- taakinhoud.

$7.4 \cdot 1.2$. De verschillen in absolute warden nader beschouwd

Overeenkomstig eerdere bevindingen blifken de beoordelingsverschillen in gemiddelde per item tussen personeelszaken en management slechts zeer gering. Deze verschillen zijn aanmerkelijk groter tussen de beoordeling van de personeelsvertegenwoordiging enerzijds en de beoordelingen van management en personeelszaken anderzijds.

Significante verschillen tussen gemiddelden worden vooral gevonden bij items die onderling hoog correleren en die betrekking hebben op meer direct-merkbare kenmerken van de arbeldssituatie. Bij de variabelen, die onderling niet significant correleren, valt het op dat de gemiddelden veelal evenmin significant verschillen. Hiervoor bestaat een tweeledige verklaring.

- Op de eerste plaats kunnen betreffende concepten een minder grote convergente validiteit bezitten. Bijvoorbeeld: een takkinhoud $\mathrm{kan}$ als onduidelijk worden beschouwd, indien met mensen geschoven wordt, maar ook indien niet duldelijk is wat tot de taak behoort.

- Op de tweede plaats kunnen de betreffende concepten wel helder zijn, maar kan de mate van hinder zeer verschillend beoordeeld worden vanult geheel verschillende referentlekaders. Bij toenemende mate van subjectiviteit in beoordelingen vallen systematische, Interorganisationele verschillen weg. Dit zou bijvoorbeeld het geval kunnen zijn bij het 1 tem: stank.

\subsubsection{Interpretatie}

De onderlinge verschillen tussen de categorleën beoordelaars 11ggen in de lijn der verwachtingen. Leden van de personeelsvertegenwoordiging oordelen in het algemeen dat werknemers meer hinder ondervinden van bepaalde werkinconveniënten. Toch is in deze geen sprake van een overall-effect, gezlen de afwljkende correlaties en gemiddelden van bepaalde variabelen. Deze afwijkende correlaties en gemiddelden worden vooral gevonden bif variabelen, die op face-value, als minder objectief meetbaar beschouwd kunnen worden. Gemeten verschillen zijn een aanwijzing dat, met name war het de materiële werkinconveniënten betreft, de overeenstemming 
tussen beoordelaars voldoende $1 \mathrm{~s}$ om te kunnen volstaan met slechts een enkele beoordelaar, Indien gekeken wordt naar verschillen tussen organisaties. Indien echter blnnen arbeidsorganisatles de hinder van bepaalde interveniënten geanalyseerd moet worden, is het beter om meerdere beoordelaars te kiezen.

7.4.2. Verschillen en overeenkomsten tussen de beoordelingen van management, hoofd personeelszaken en leden personeelsvertegenwoordiging enerzijds en de gemiddelde werknemersbeoordeling anderzijds

De analyses betreffende de bovengenoemde overeenkomsten en verschillen, zijn op eenzelfde manler verricht als die betreffende de beoordellngen van management, personeelszaken en personeelsvertegenwoordigling onderling. De verschillen en gemiddelden tussen de beoordelingen van deze drie categorieën beoordelaars enerzijds en de gemiddelde beoordeling van de werknemers ander$z 1 j d s$ zijn vermeld in tabel 7.5. (de p-waarden zijn berekend op basis van tweezijdige toetsing). 
Tabel 7.5. Discrepantie-analyse van de beoordeling ten aanzien van de gemiddelde arbeldsomstandighedenscores van de werknemers versus die van de overige categorieên beoordelaars.

\begin{tabular}{|c|c|c|c|c|c|c|}
\hline \multirow{3}{*}{ 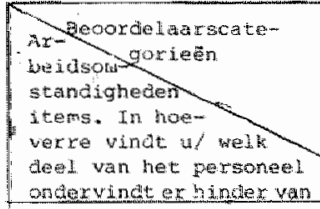 } & \multicolumn{6}{|c|}{ 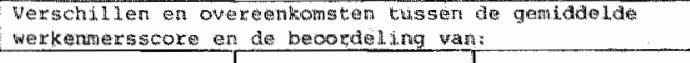 } \\
\hline & \multicolumn{2}{|c|}{ Mala nargement: } & \multicolumn{2}{|c|}{ petsoneel siaken } & \multicolumn{2}{|c|}{$\begin{array}{l}\text { parmoned sver- } \\
\text { tegenoordig ing }\end{array}$} \\
\hline & I & $\mathrm{x}$ & $x$ & $x^{2}$ & I & ${ }^{T}$ \\
\hline Triting & .55 * * * * & 1.28 & $.37 * *$ & 0.47 & $46^{*} \times 1$ & $-2.40 *$ \\
\hline Kot de / wartrte & .23 & $3.95^{\mathrm{k}} \mathrm{k}$ & $.41 * *$ & $4.99 * *$ & $.30 *$ & -1.10 \\
\hline La & $.61 \mathrm{kn} * \mathrm{k}$ & $2.57 *$ & $.64 * *$ & 4.1 .3 & $.76 *$ & 0.06 \\
\hline val i 1. & .61 tot in & 1.50 & $.66^{\cdots *}$ & $1.9: \mathrm{L}^{\mathrm{k}}$ & $.58 * *$ & -0.32 \\
\hline Focht, worcht & .24 & 1.04 & $.37 * *$ & $2.15 *$ & $.30 *$ & -0.36 \\
\hline Stank & $.45^{\mathrm{dr}} \mathrm{tw}$ & $3.74 * *$ & $.59+k \pi$ & 3.21 to & .25 & $2.03 * *$ \\
\hline 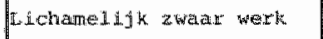 & $.39 *$ & $-2.12 *$ & $.55 * x x$ & $-1.88^{*}$ & $.40 \times$ & -3.96 से \\
\hline Gittuge stoffen & $.60 *$ & $2.30 *$ & .36 & $1.81 *$ & .21 & -1.14 \\
\hline Geestelljk ware wherk & $.74 * \pi$ & 9.89 & $.65 k$ in & $2.26 *$ & $.49 * * \pi$ & -0.55 \\
\hline $\begin{array}{l}\text { Te weinig writheld on het } \\
\text { werth zelf in te delen }\end{array}$ & -.01 & -0.21 & .05 & -1.94 & $39 * *$ & $-2,466^{*}$ \\
\hline The hoog arbeidstempa & -.00 & $1.68 *$ & .05 & 1.55 &.- .09 & -1.05 \\
\hline Eentonig werk & .21 & -1.94 & $.41 * * *$ & $-2.11 * *$ & $\therefore$ A 4 A & $-4,35 * k$ \\
\hline 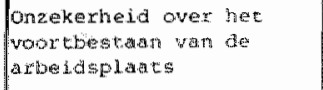 & $.51 * *$ & 1.36 & $=44 \times \cdots$ & $2.34 *$ & 13 & -0.01 \\
\hline $\begin{array}{l}\text { Swechte onder } 1 \text { inge var } \\
\text { houdingari }\end{array}$ & .26 & $-2.65 *$ & .24 & $-2.63 * *$ & -.21 & $-\pi .05^{2}=$ \\
\hline Onduidellike takinhoud & $.36 *$ & -6.50 & .11 & -1.30 & .24 & -7.01 \\
\hline \multicolumn{7}{|l|}{$M=40$} \\
\hline \multicolumn{7}{|l|}{$p 60.01$} \\
\hline \multicolumn{7}{|l|}{$* 0.014 p<0.05$} \\
\hline$\Rightarrow \quad 0.05<p \leqslant 0.10$ & & & & & & \\
\hline
\end{tabular}


Analoog aan de voorafgaande analyses zal de bespreking van de overeenkomsten en verschillen platsvinden aan de hand van de betreffende gemiddelden en correlaties.

Allereerst $21 j$ geconstateerd dat de gemiddelde beoordelingen van de werknemers in het algemeen niet consistent afwijken, noch overeenkomen met de beoordelingen van een van de overige beoordelaars.

7.4.2.1. De correlaties tussen de beoordelaars nader beschouwd

Hoewel de gemlddelde werknemersscore over het algemeen, althans wat de correlaties betreft, een grote mate van overeenkomst vertonen met die van de overige beoordelaars geldt dit niet voor de 1tems:

- te hoog arbeidstempo,

- slechte onderlinge verhoudingen,

en in mindere mate voor de items

- giftige stoffen,

- te weinig vrijheld om het werk zelf in te delen,

- onzekerheld over het voortbestaan van de arbeidsplaats,

- onduldelijke taakinhoud.

Nog sterker dan in de vorlge paragrafen blijkt, dat vooral een aantal immaterlële arbeldsomstandighedenttems over onvoldoende convergente validiteit beschikken. Bovendien is opvallend dat opnleuw het 1 tem 'giftige stoffen' tot de 1 tems met een geringe convergente validiteit behoort, voorzover een geringe kennis van de mate van giftigheid van de verschillende, in het arbeidsproces voorkomende, stoffen daaraan debet is, vormt deze onwetendheld een overigens verontrustende verklaring.

Wel moet rekening gehouden worden met het feit dat veelal slechts een kleine steekproef van de werknemers uit een bedrijf geinterviewd is, waardoor opnieuw gesteld, een vertekening mogelijk is, zonder dat voorspelbaar is welke richting deze vertekening heeft. Het is dan toch nog opvallend hoe vaak een 'gelijk' beoordelingspatroon gevonden wordt. Blijkbaar is het arbeldsomstandighedenklimaat voor een organisatie een uniform organisatiekenmerk, althans voor de categorle direct-uitvoerend personeel. Een derge$11 \mathrm{jk}$ 'gel1jk' beoordelingspatroon tussen beoordelaars is gevonden bif de 1 tems:

- trilling,

- 1awaal,

- vuil,

- 11chame11jk zwaar werk en 
- geestelijk zwaar werk.

Deze gelijkenis geldt wel een beperktere groep 1 tems dan de bevindingen beschreven in par. 7.4.1., hetgeen verklaarbaar is vanuit de anderssoortige vraagsteling in combinatie met de representativiteit. De tendens die uit beide bevindingen spreekt komt overigens wel overeen: items betreffend materiëel hinderende arbeldsomstandigheden geven een grotere kans op overeenkomst, dan items betreffende immateriëel hinderende arbeidsomstandigheden.

7.4.2.2. De gemiddelden van de verschillende beoordelingen nader beschouwd

Werd eerder geconstateerd dat de personeelsvertegenwoordiging de arbeldsomstandigheden negatiever beoordelen dan het management of personeelszaken, dezelfde tendens blijkt in grote lijnen eveneens op te gaan voor de gemiddelde werknemersscore, zij het minder consistent. Zo is het werk volgens de gemiddelde werknemersscore minder eentonig, minder lichamelijk zwaar, heeft men meer mogelijkheden om het werk zelf in te delen en zijn er betere onderlinge verhoudingen dan de beoordeling van het management of hoofd personeelszaken aangeeft.

De gemiddelde werknemersscore is op alle thems positiever dan de beoordeling, zoals deze gegeven wordt door leden van de personeelsvertegenwoordiging, met uitzondering van de 'hinder van stank'. Werknemers geven meer dan de drie overige beoordelaars aan dat zij hinder hebben van stank.

\subsubsection{Interpretatie}

De werknemersscore, ofschoon slechts gebaseerd op een relatief klein aantal werknemersbeoordelingen, lifkt vooral ten aanzlen van de beoordeling van de materièle arbeldsomstandigheden een representatief beeld te geven ten aanzien van de mate, warin werknemers hinder hebben van spectflek aangeduide arbeidsomstandigheden. Bevestigd wordt de eerder getrokken conclusie, dat een goede vergelijking van die 1 tems mogelijk is op basis van slechts een enkele categorie beoordelaar; als beperking geldt dan echter wel dat het een vergelijking tussen organtsaties betreft. Bepaling van de mate, waarin binnen éen organisatie het personeel hinder ondervindt van specifieke arbeldsomstandigheden, kan echter niet zonder meer door middel van interviews van een enkele beoordelaar gedaan worden, gezien de divergentie tussen de diverse beoordelaars. 
We1 zif tenslotte opgemerkt dat deze tabel geen aanlelding geeft om te constateren dat er sprake is van een overall arbeidsomstandighedenvariabele die de beoordeling domineert.

\subsection{De Multitralt-Multimethod-Matrix}

Ook in dit kader $z a l$, alvorens in te gaan op de meer gedetallleerde bespreking van de MTMM-matrices, een globaal overzicht gegeven worden van enkele belangrijke kenmerken van de in de volgende paragrafen beschreven MTMM-matrices.

overeenkomend met de procedure in par. 6.4. $\mathrm{zal}$ in tabel 7.6. aangegeven worden welk percentage van de correlaties significant $(\mathrm{p}<.10)$ is en hoe hoog de mediaanwaarde van elke groep correlaties 1s. Deze gegevens zullen ingedeeld worden naar de aard van de correlaties (zle 6.4.).

Tabe1 7.6. Enkele overal1-kenmerken van de MTMM-arbeidsomstandighedenitems-matrices.

\begin{tabular}{|c|c|c|c|}
\hline $\begin{array}{l}\text { Aard van de } \\
\text { correlaties }\end{array}$ & Beoordelaars & Mediaan & $\begin{array}{l}\text { Percentage } \\
\text { significante } \\
\text { correlaties }\end{array}$ \\
\hline $\begin{array}{l}\text { Interrater } \\
\text { convergente } \\
\text { correlaties }\end{array}$ & $\begin{array}{l}\text { management - p.z. } \\
\text { management - pers.vert. } \\
\text { pers.zaken - pers.vert. } \\
\text { pers.vert. - werknemers }\end{array}$ & $\begin{array}{l}.46 * * * \\
.37 * * * \\
.31 * * * \\
.30 * *\end{array}$ & $\begin{array}{l}87 \% \\
73 \% \\
80 \% \\
80 \%\end{array}$ \\
\hline $\begin{array}{l}\text { Intrarater } \\
\text { correlaties }\end{array}$ & $\begin{array}{l}\text { management } \\
\text { personeelsaaken } \\
\text { pers.vert. } \\
\text { werknemers }\end{array}$ & $\begin{array}{r}.06 \\
.19 \\
.17 \\
.20\end{array}$ & $\begin{array}{l}42 \% \\
54 \% \\
50 \% \\
60 \%\end{array}$ \\
\hline $\begin{array}{l}\text { Interrater } \\
\text { correlaties } \\
\text { (verschil- } \\
\text { lende 1tems) }\end{array}$ & $\begin{array}{l}\text { management - pers.zaken } \\
\text { management - pers.vert. } \\
\text { pers.zaken - pert.vert. } \\
\text { pers.vert. - werknemers }\end{array}$ & $\begin{array}{l}.05 \\
.02 \\
.09 \\
.06\end{array}$ & $\begin{array}{l}39 \% \\
28 \% \\
42 \% \\
37 \%\end{array}$ \\
\hline
\end{tabular}


Opnieuw blijkt dat de correlaties tussen dezelfde items over verschillende beoordelaars, zowel vaker significant zijn als een hogere mediaanwaarde hebben, dan de correlaties uit de beide andere groepen beoordelingen. Dit is een aanwijzing voor een in het algemeen redelijke convergente validiteit van de metingen; op de verschillen tussen de items zal in de volgende paragrafen worden ingegaan.

Het blijkt dat de intrarater correlaties een gemiddeld hogere mediaanwaarde hebben en vaker significant zijn, dan de interrater correlaties. Dit kan veroorzaakt worden doordat arbeldssituaties die gekenmerkt worden door een bepaalde hinderlijke inconveniënt (zoals lawaai), veelal ook gekenmerkt zullen worden door andere hinderlijke inconveniënten. De samenhang binnen de intrarater correlaties moeten dan ook gezien worden als veroorzaakt door een algemene slechte kwalitelt-van-de-arbeld factor (vergelijk Bartlett, 1983).

7.5.1. De MTMM-arbeidsomstandighedenitems-matrices tussen management en hoofd personeelszaken

De MTMM-matrices (zie tabel 7.6.), bestaan enerzijds ult de correlaties tussen de beoordelingen van het management en hoofd personeelszaken ten aanzien van een vijftiental arbeidsonstandigheden en anderzijds uit de correlaties tussen de items per beoordelaar. 

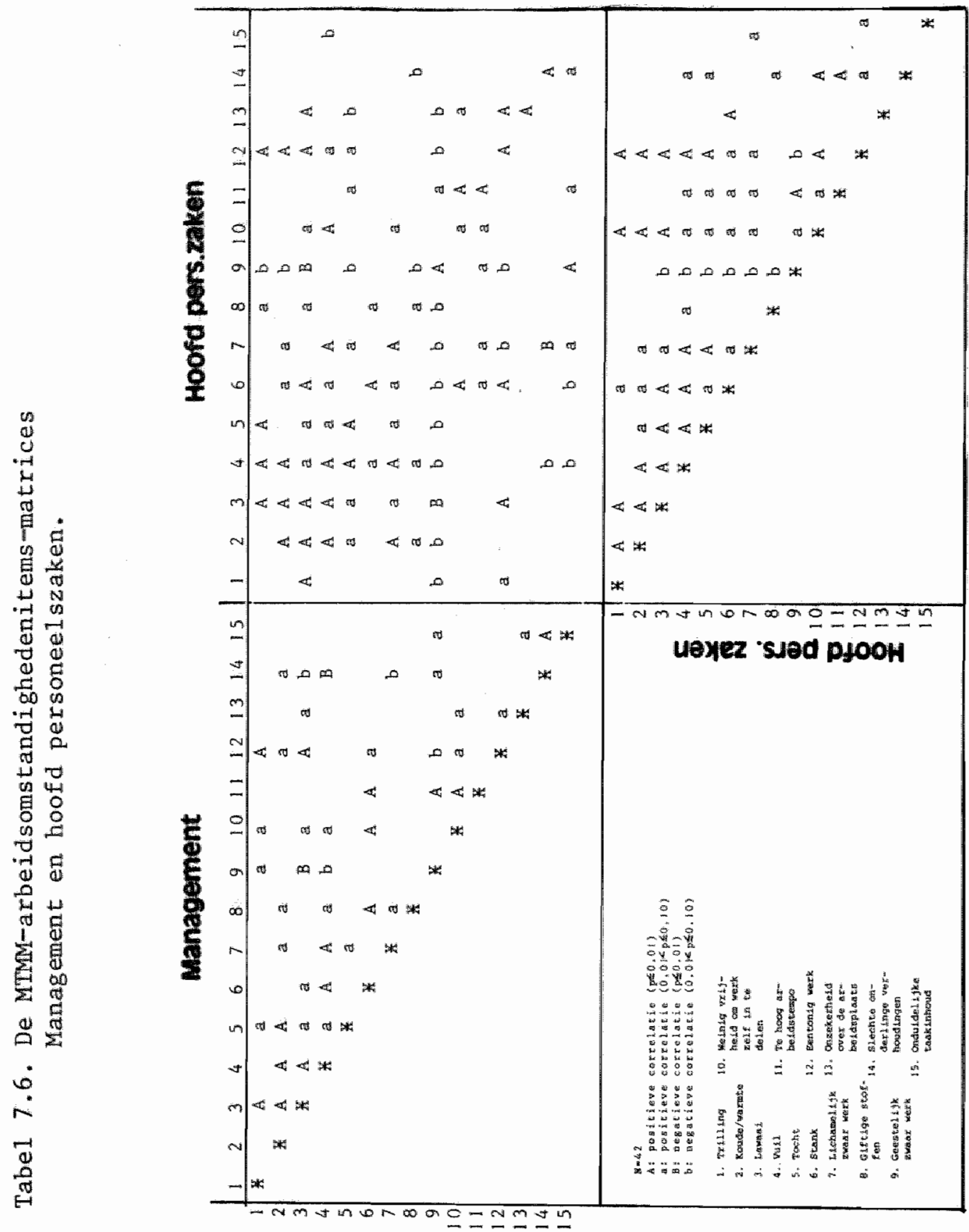
In deze matrix zijn uitsluttend de significante correlaties schematisch weergegeven $(p \leqslant .10)$. Voor een volledig overzicht van alle correlaties wordt verwezen naar bijlage 9 .

\subsubsection{De 'management-matrix'}

Binnen de management-matrix vertoont een tweetal variabelen een signiflcante correlatie met betrekkelijk veel overige arbeldsomstandighedenitems, namelijk de twee items: lawal en vul1. B11jkbaar vormen deze twee omstandigheden een belangrijke graadmeter, voor de (materiële) omstandigheden waronder het werk plaatsvindt.

Een tweede constatering is, dat de arbeldsomstandighedenitems, die een aspect $z i j n$ van de materiële, fysleke omgeving, relatief veel hoge intercorrelaties hebben. Voor de items die betrekking hebben op immateriële arbeidsomstandigheden geldt dit in mindere mate.

De oorzaak van de hoge intercorrelaties tussen de materiële arbeldsomstandighedenitems moet worden gezocht in een generale arbeidsomstandighedensituatie. Vandaar dat hier niet gesproken wordt over een systematische meetfout (bias). Vaak zullen bepaalde werkzaamheden gekenmerkt worden door een cumulatie van slechte, dan wel goede arbeldsomstandilgheden. Hetzelfde geldt voor de intercorrelaties van de immateriële arbeidsomstandighedenttems: een onduidelijke taakinhoud, kan mede aanleiding $z i j n$ voor een. 'geestelijke" verzwaring van het werk in psychisch opzicht incluslef de onderlinge verhoudingen.

De 1 thtercorrelaties binnen deze beide groepen zijn dan ook positief, terwijl tussen items uit elk van deze belde groepen afzonderlifk ook negatieve, signiflcante relaties voorkomen, met andere woorden: werkzamheden die lichamelijk belastend $z 1 j n$ worden nilet automatisch ook als geestelifk belastend beoordeeld.

\subsubsection{De 'personeelszaken'-matrix}

Sterker nog dan bij de 'management'-matrix zijn in de 'personeelszaken'-matrix een groot aantal intercorrelaties op te merken. Maar liefst 6 van de 15 items correleren met tenminste tien van de overige veertien items. Het betreft hier overwegend 1 tems die de materiële werkomgeving betreffen, namelijk: vuil, tocht, stank, 1ichamelifk zwaar werk, welnig vrifheid on het werk zelf in te delen en eentonig werk.

Deze beide laatste items kunnen zowel gezlen worden als typerend 
voor de materiële omgeving (de machine bepaalt het tempo), als ook voor de immateriële interveniènten (weinlg ultdagend en saa1). We1 wordt overeenkomstig de 'management'-matrix een tweedeling gevonden in zowel onderling sterk correlerende als immateriële arbeldsomstandighedenitems. Eveneens blijkt uit deze matrix, dat geestelifk zwaar werk niet samen hoeft te gaan met materiële arbeldsinconveniênten.

7.5.1.3. De onderlinge vergel1jking van MTMM-arbeldsomstandigheden-matrices

Alvorens over te gaan tot de bespreking van de "interbeoordelaars"-matrix, zal een vergelijking gemaakt worden van de beide eerder beschreven matrices. Opvallend 1s, dat de items met de meeste intercorrelaties, de materiële arbeldsomstandigheden betreffen. De onderlinge samenhang tussen deze items is groter dan die tussen de items, die een ultdrukking vormen van de immateriële inconventënten; dit wordt waarschijnlijk veroorzaakt door éen generale arbeidsomstandigheden factor. Bij het management betreft deze samenhang vooral smerig en lawaierig werk, bij personeelszaken is in dit opzicht een aanmerkelijke uitbreiding te zien namelijk naar de variabelen te weinig vrijheld om het werk zelf in te delen en 'eentonlge werkzaamheden'. Laatstgenoemde aspecten die vooral 'de Inhoud van het werk' betreffen, b11jken begrijpelijkerwijs voor personeelszaken belangrijker dan voor het management.

Dertien van een vijftien items voldoen aan de vereisten voor een voldoende convergente validiteit. De verschillen in significantlenlveau tussen deze resultaten en de resultaten beschreven in 7.4., worden veroorzaakt door een verschillende manler van toetsing (eenzijdig versus tweezifdig). Overigens voldoen slechts een drietal items volledig aan de criteria voor een voldoende discriminante validiteit: lawal, geestelijk zwaar werk en onzekerheid over het voortbestaan van de arbeldsplaats. De drie volgende ttems voldoen bijna aan die criterla: vull, 11chamelijk zwaar werk en te hoog arbeldstempo.

Het betreft hier de zes variabelen waarover de onderlinge beoordelingen een sterk overeenkomend antwoordpatroon laten zien, terwijl deze items zich onderschelden van andere items; $z i j$ hebben de (bijna) hoogste correlaties met zichzelf, tussen beoordelarrs. Opvallend is dat het hier zowel items betreft, die zowel een weerslag vormen van materiële, als van immateriële inconveniënten. De directe zicht-, hoor- en rulkbaarheid wordt dus niet 
beter als zodanig onderscheiden dan geestelljk zwaar werk of onzekerheid over het voortbestaan van de arbeldsplaats. Werk dat gepaard gaat met veel materiële en fysische inconveniënten wordt gepercipleerd als niet geestelijk-belastend.

Uit de intercorrelatles in deze matrix blijkt, dat de materlële inconveniënten van een arbeldsplaats sterk met elkaar samenhangen; dit in tegenstelling tot de immateriële inconveniënten. Tenslotte vormt het ontbreken van hoge intercorrelaties in deze matrix een bevestiging van de verschillende optiek in en het verschillend belang dat gehecht wordt aan de mate van vrijheid in en eentonigheid van het werk door de diverse categorieën beoordelaars, in casu het management en het hoofd personeelszaken.

7.5.2. De MTMM-arbeidsomstandighedenitem-matrix tussen management en personeelsvertegenwoordiging

Daar de management-matrix reeds besproken is zal de beschrifving hier beperkt worden gevolgd door een analyse van de personeelsvertegenwoordiging-matrix, waarna beide matrices onderling zullen worden vergeleken. De correlatie-matrices betreffende de arbeidsomstandighedenitems zijn weergegeven in tabel 7.7. Ook hier geldt dat de significante correlaties schematisch zijn aangegeven; de volledige matrix is vermeld in biflage 9 . 


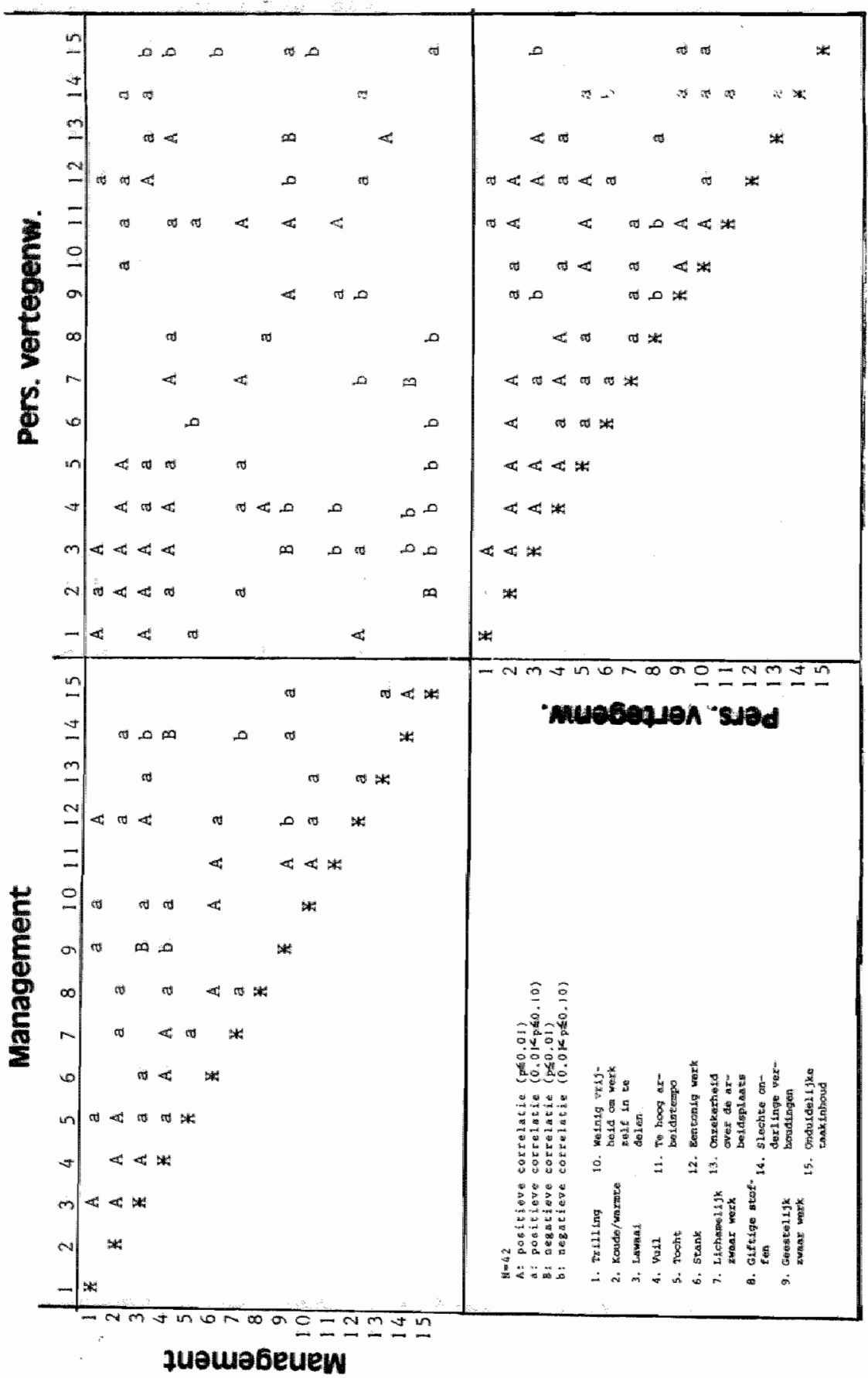


7.5.2.1. De "personeelsvertegenwoordig1ng-matrix"

Er is een enkel 1 tem, dat met tien van de veertien overige items een significante relatie vertoont, te weten: tocht/vocht. Vijf andere items vertonen een significante relatie met negen van de veertien overige items, namelijk: koude/warmte, lawaal, vuil, lichamelijk zwaar werk en te weinig vrijheld on het werk zelf in te delen.

Ook hier is het opvallend, dat op een na leder van deze items betrekking heeft op de materiële arbeldsomstandigheden. Zoals reeds eerder gezegd kan het item "te weinig vrijheld om het werk zelf in te delen' zowel beschouwd worden als een ulting van materiële, als van immateriële inconveniënten. De hoge correlaties tussen dit 1 tem en een aantal items, die een maat zouden moeten zijn van de immateriële arbeidsomstandigheden lijken erop te duiden, dat dit item het centrale item is voor de immateriele arbeidsinconveniënten. Ook in deze matrix zijn de sterkste intercorrelaties gecentreerd rond de mate waarin hinder ervaren wordt van fysieke arbeidsomstandigheden. Een tweede minder sterke intercorrelatie valt op te merken in de sector 'immateriële arbelidsomstandigheden' .

7.5.2.2. Onderlinge vergelijking van de MTMM-arbeidsomstandigheden-matrices

De beoordelingen door het management vertonen een negatieve relatie wat betreft de mate, warin geoordeeld werd dat hinder van geestelijk zwaar werk samenhangt met 'vull" werk. Bij de beoordeling van de personeelsvertegenwoordiging blijkt echter dat deze belde niet voor iedere categorie beoordelaars negatief samen hoeven te hangen. Dit lijkt exop te duiden dat er twee verschillende opvattingen bestaan over geestelljk zwaar werk. Voor de een lijkt het dat geestelijk zwaar werk een resultante is van 'vul1' werk, terwijl voor de ander 'arbeld' wordt gekenmerkt door ofwel 'vul1' ofwel 11chamelijk zwaar. Dit leidt echter tot een negatieve relatie ten aanzien van deze items tussen deze belde categorieën beoordelaars. Opvallend is, dat de belangrijkste 1tems, zoals die uit de management-matrix naar voren $z i j n$ gekomen, overeenkomen met de belangrijkste personeelsvertegenwoordigingsitems, zif het met de aantekening, dat door de personeelsvertegenwoordiging meer 1tems als centraal blijken te worden beschouwd. Op basis van de interbeoordelaars-matrix kan geconstateerd worden, dat: 
- elf van de wiftien items beschikken over voldoende convergente validiteit;

Niet over voldoende convergente validiteit beschikken de items: vocht/tocht, stank, te weinig vrifheid on het werk in te delen en slechte onderlinge verhoudingen. Het ontbreken van een voldoende convergente validitelt kan zowel haar oorzaak vinden in een onvoldoende eenduldigheld van het begrip, als in een onbekendheld met de ervaren mate van hinder.

- van deze elf items beschikken er slechts twee over een voldoende discriminante validiteit; dit betreft de items: lawaal en 1ichamelijk zwaar werk. Een 1tem (trilling) voldoet zo goed als bijna aan het betreffende criterium. Het betreft hier wederom een aantal materiële inconveniënten.

ofschoon 'geestelijk zwaar werk' binnen de intra-beoordelaarsmatrlx een tegengestelde relatie heeft met de materiële arbeidsomstandighedenitems (management: negatief; personeelsvertegenwoordiging: positief), correleren betreffende items onderling toch hoog positief met elkaar. Ondanks de bestaande verschillen in beoordelingen ten aanzien van de mate waarin een taak met veel materlële inconveniënten ook geestelijk belastend 1s, blifkt er derhalve toch overeenstemming te bestaan tussen de onderhavige beoordelaars wat betreft de mate warin werkzaamheden -over meerdere organisaties heen- als meer of minder geestelijk belastend worden beschouwd.

De hier genoemde bevindingen vormen een sterke aanwijzing voor het bestaan van een gedifferentiëerde beoordeling van de verschillende ttems en daarmee tot het ontbreken van een overall ha1o-effect.

7.5.3. De MTMM-arbeldsomstandigheden-matrix van personeelszaken en personeelsvertegenwoordiging

De betreffende MTMM-matrix bevindingen zijn schematisch weergegeven in tabel 7.8. De volledige matrix is weergegeven in bijlage 9. 


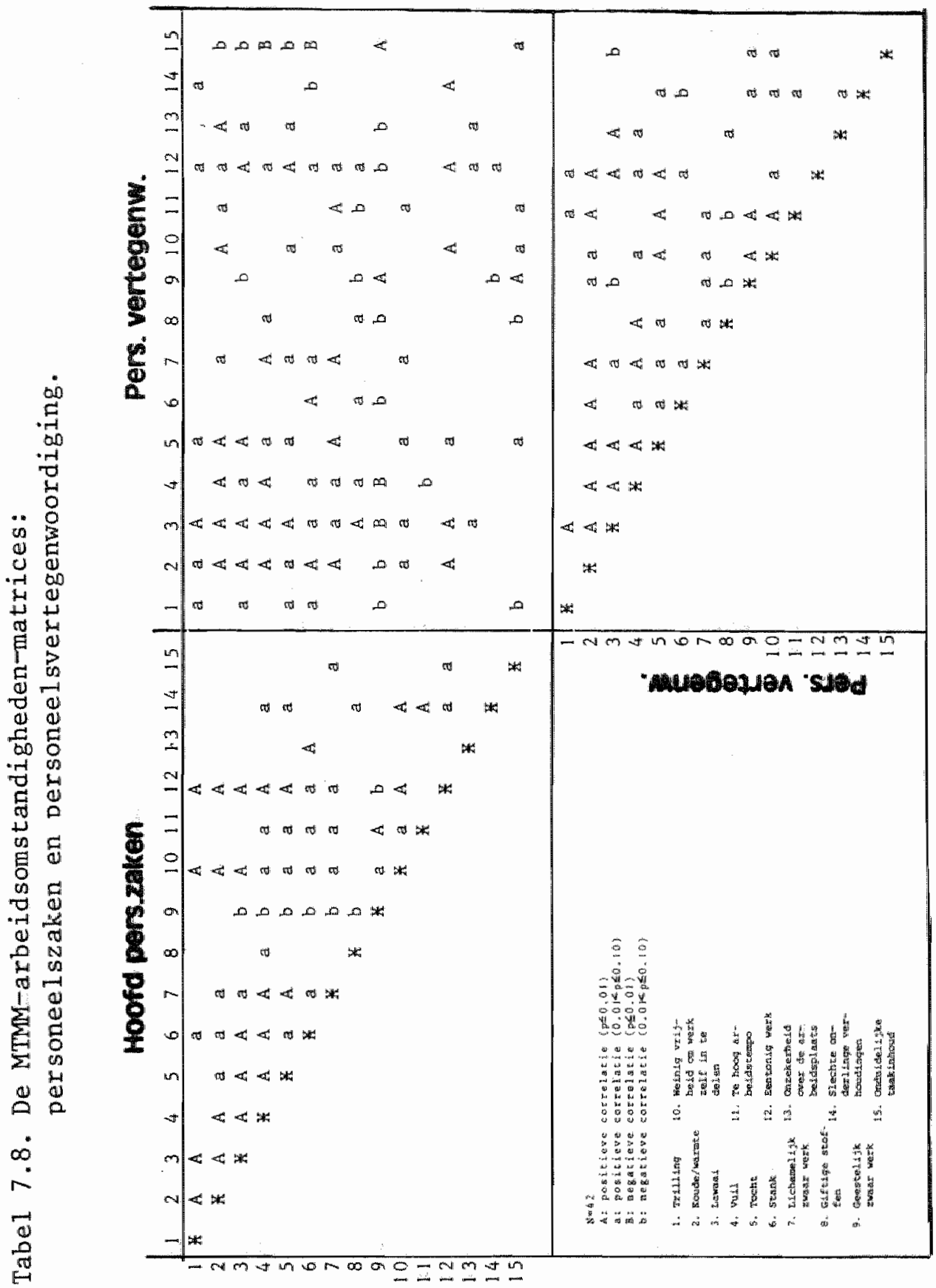


Omdat de beide intra-beoordelaars matrices reeds besproken zijn, zal de bespreking daarvan gericht worden op de onderlinge vergelijking van deze belde intra-beoordelaars matrices en van de interbeoordelaars-matrix.

7.5.3.1. De onderlinge vergelijking van de arbeldsomstandighedenitems-matrices

De centrale items in beide intra-beoordelaars matrices vertonen een vrij sterke mate van overeenkomst. Naast het item "te weinig vrijheld om het werk zelf in te delen' blijken vooral de items die de fysteke arbeldsomstandigheden beschrijven een centrale plaats in te nemen.

overeenkomstig de bevindingen bij vergelifking van de 'management'- en 'personeelsvertegenwoordiging'-matrix, blijkt de eenduldige relatie, traceerbaar bij personeelszaken namelijk dat vuil, lawalerig werk negatief samenhangt met geestelijk $\mathrm{zwaar}$ werk, niet in de matrix van de personeelsvertegenwoordiging terug te vinden 1 s.

Met de aandacht gericht op de interbeoordelaar-matrix valt te constateren, dat twaalf van de vijftien items voldoen aan de verelsten voor de convergente validitelt.

Deze items blijken slechts in één enkel geval eveneens een vo1doende discriminerende validiteit te bezitten, namelijk geeste$11 \mathrm{jk}$ zwaar werk. Een ander item voldoet bijna aan dat criterium: slechts één correlatie is hoger dan de intra-item correlatie, namelijk: 1ichamelijk zwaar werk. Ondanks de hoge intercorrelaties bif de spectfieke omschrijving van de materlële arbeidsomstand1ghedenttems blijken deze 1 tems met meer dan één ander item hoger te correleren.

Overigens representeren deze belde 1 tems wel de belde groepen arbeidsinconventënten, die verondersteld worden in het materlaal aanwezig te $z 1 j n$.

7.5.4. De arbeldsomstandighedenitems-matrix 'gemiddelde werknemersscore'

Gezien het conslstente beeld van de MTMM-matrices, zoals voorafgaand beschreven, 1 ijkt het niet zinvol de betreffende MTMMmatrices van de gemiddelde werknemersscores met die van de overige beoordelaars te beschrifven. Gezien de dubbele representatie van de werknemers in de verkregen data is het wel de moefte waard om de gemiddelde werknemersbeoordeling te vergelijken met de 
beoordeling van de personeelsvertegenwoordiging. De resultaten van die vergelijking zijn weergegeven in tabel 7.9. Voor de volledige correlatie-tabel wordt verwezen naar bijlage 9. 


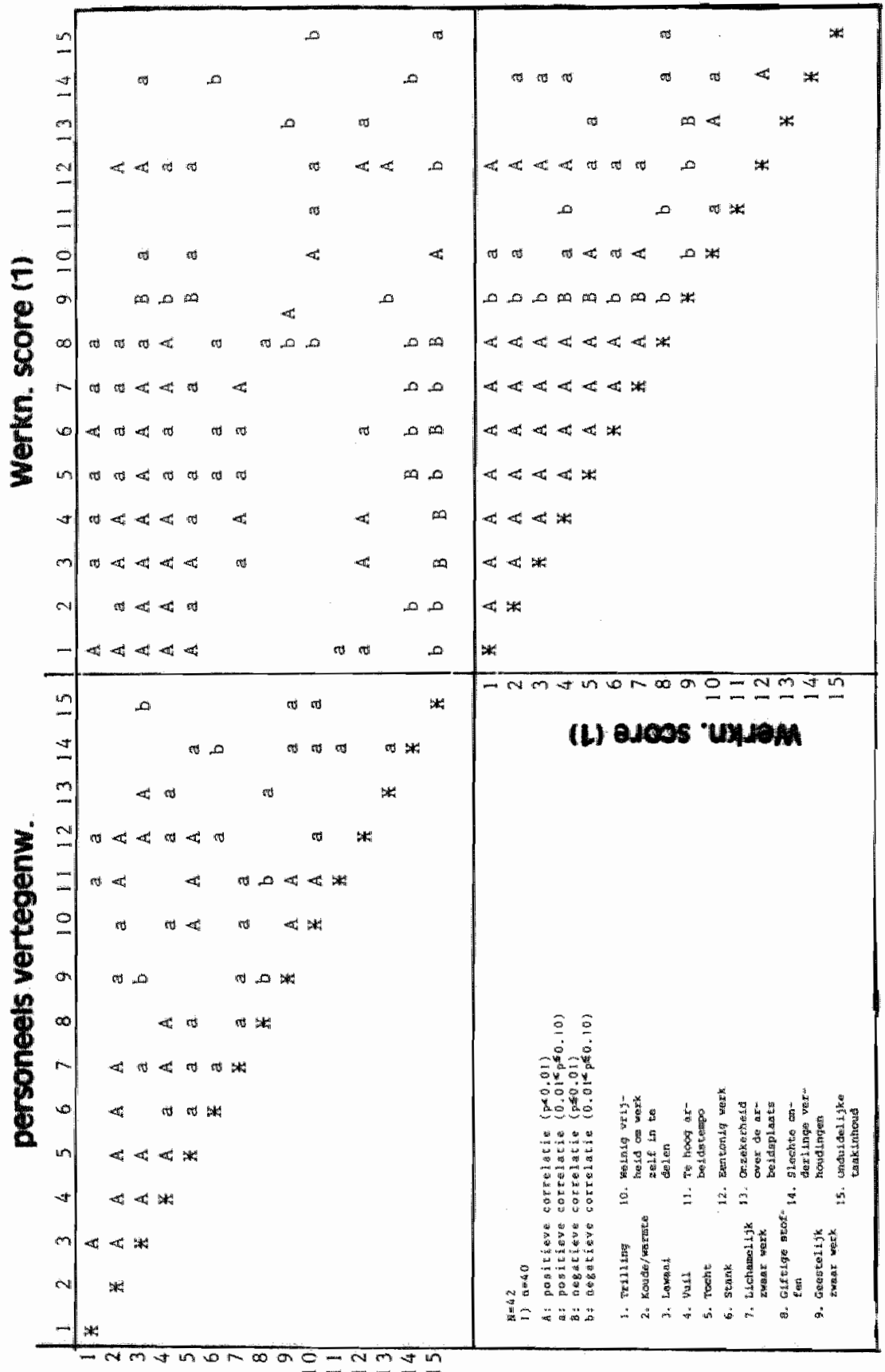


7.5.4.1. De intrabeoordelaarcorrelatie werknemersscore-matr $1 x$

De correlaties tussen de meer materiële arbeldsomstandigheden zeer hoog. De discriminerende warde tussen de items is zeer gering. In een sub-matrix een matrix van de 12 onderling sterkst correlerende items blijken van de 55 mogelijk significante correlaties er maar liefst 51 significant te $z i j n$, waarvan 37 met een $\mathrm{p}<0.01$. Ten aanzien van de meer immateriële items is geen duidelijke interne samenhang te constateren.

De matrix zelf levert het beeld op van een beoordeling van de materiële arbeidsomstandigheden vanuit een zeer eenvormige (valide of Invalide) response-set, terwlj1 de meer materiële arbeidsomstandigheden zich duidelijk meer lenen voor multiple-interpretaties.

7.5.4.2. De onderlinge vergelijking van de MTM-arbeidsomstandigheden-matrices

Van de 15 items bezitten er drie een onvoldoende convergente validiteit. Een voldoende discriminante validiteit is slechts bij één item aanwezig, namelijk b1j 'geestelijk zwaar werk'. Het ontbreken van een voldoende convergente validiteit bij met name de materlële arbeidsomstandighedentem moet verklaard worden door de hoge intercorrelaties tusen deze items bij de werknemersscores. Ten aanzien van het concept 'geestelijk zwaar werk' valt op, dat ondanks de hoge correlaties tussen de beoordelingen $(r=.49)$, de relatie van de beoordeling van dit item door de werknemers met die van de materiële arbeidsomstandigheden sterker negatief is dan bij de personeelsvertegenwoordiging. Ten aanzien van de overige correlaties is een weinig coherente structuur te ontdekken.

\section{6.}

Samenvatting van de bevindingen

In dit hoofdstuk $z i j n$ de beoordelingen van de arbeidsomstandigheden besproken. Opvallend daarbij is een grote mate van overeenkomst tussen de uitspraken van de diverse beoordelaars, voorzover deze liggen op een geaggregeerd niveau. Arbeldsomstandigheden blifken negatiever beoordeeld te worden in rangorde van categorleën beoordelaars: van management, via personeelszaken, via gemiddelde werknemersscore, tot personeelsvertegenwoordiging. Op basis van interitem-correlaties blijken ten aanzien van het organisatiekenmerk: arbeidsomstandigheden veelal twee versch11lende structuren duidelijk te onderschelden: een complex van 
materiële en een complex van immateriële omstandigheden. De beoordelingen van de items vertonen in het algemeen, zoveel nuanceringen en onderscheldingen, dat in deze geen sprake is van een systematische fout (bias). Bij de gemiddelde werknemersscore kan er mogelijk gesproken worden van een ongedifferentieerde beoordeling van de materièle arbeldsomstandigheden. Wel wordt een bevestiging gevonden van de typering van taken naar eenzelfde soort (positieve of negatieve) arbeldomstandigheden. 
HOOFDSTUK 8: DISCREPANTIE EN CONCORDANTIE NADER BESCHOUWD

8.1. Inleiding

In hoofdstuk 2 zijn een aantal organisatieaspecten beschreven die een samenhang vertonen met een verhoogde verzuimfrequentie, verzulmour en het aantal WAO/IP-toetredingen. Dergelijke relaties, die over de arbeidsorganisaties heen gevonden zijn, bieden op organisatieniveau mogelijkheden voor verzulmbeperkende en/of gezondheldsbevorderende interventies. Ter ontwlkkeling van deze mogelijke interventies dienen vanuit het brede scala van verzuimbeinvloedende factoren bij voorkeur die kenmerken geselecteerd te worden, die voor de betreffende spectfieke arbeldsorganisatle relevant $z i j n$. Daarvoor moet per organisatie informatie verkregen worden over de gezondheidsbedrefgende en -begunstigende omstandigheden in de organisaties.

De analyses in de voorafgaande hoofdstukken $z \mathbb{1 j n}$ verricht om inzicht te krijgen in de vraag bij wie in de arbeidsorganisatie relevante informatie te verkrijgen is over mogelijke bronnen voor een verhoogd verzuimgedrag. Mogelijk leveren -zo was de veronderstelling- de onderschelden categorleën beoordelaars een ander beeld ten aanzien van de verschillende relevante organisatieaspecten, welke samenhangen met de verzulm- en arbeldsongeschiktheidsindicatoren. Een dergelijk verschillend beeld in de perceptie van de arbeldssituatie kan invloed hebben op het gedrag van werknemers in organisaties (Dessler, 1980). Dientengevolge zal een grote mate van discrepantie een belangrijke rol kunnen spelen, met name ten aanzien van het succes van organisatieveranderingsprocessen. Hierbij is vooral de positle van de respondent in het geding, evenals de wijze warop met verschilien in informatle kan worden ongegaan. On de brulkbaarheld voor het organisatieadvieswerk van dit 'diagnostisch' material te kunnen beproeven dienen wel een antal critische vragen beantwoord te worden, zoals:

- zifn de discrepanties in de werkorganisatle organlsatiekenmerken of statistische artefacten $(8.2 .1$.$) ,$

- wat is de betekenis van de betreffende bevindingen voor onderzoek op het niveau van de arbeidssituatie $(8.2 .2$.$) ,$

- wat is de betekenis van de verschillen in de beoordeling van de verschillende 1 tems voor mogelijke interventies (8.2.3.).

Op basis van de analyses, zoals deze in de hoofdstukken 5,6 en 7 verricht $z i j n$, wordt in dit hoofdstuk ingegaan op deze vragen. 
Vervolgens zal ingegaan worden op mogelljke bronnen voor en oorzaken van discrepantle binnen de arbeldsorganisatie (8.3.).

Afslutend worden nog een aantal aanvullende suggesties gegeven $(8.4$.$) .$

8.2.1. Organisatiekenmerk of statistisch artefact

ofschoon een sterke onderlinge samenhang van beoordelingen binnen een enkele beoordelaarscategorie niet hoeft te wijzen op een invallde meting (zle hoofdstuk 3), zal wel de mogelijkheid onderzocht moeten worden of de discrepantie, zoals deze in dit onderzoek gemeten 1s, veroorzaakt wordt door één systematische vertekening, of een organlsatiekenmerk 1s. Gegeven de bevindingen van de hoofdstukken 5,6 en $7 \mathrm{zijn}$ er geen aantoonbare aanwijzingen dat de betreffende resultaten het effect $z 1 \mathrm{jn}$ van een systematische meetfout. Wel blljkt een directe samenhang te bestaan tussen de beoordeling van arbeldsomstandigheden en de discrepantievariabelen (plafond-effect). Daar de discrepantlevariabelen voor een groot deel opgebouwd $z i j n$ uit de verschillen in beoordeling van de arbeidsomstandigheden-items is er hier een risico van contaminatle aanwezig. In de analyses van de discrepantievariabelen is dan ook met dit risico rekening gehouden. Daarbij is uit de analyses gebleken dat er duidelijke aanwijzingen zijn, dat de discrepantle veroorzaakt wordt door andere factoren die de organisatie betreffen; dit blijkt onder andere uit:

- de hoge mate waarin de directe warneembaarheld van arbeldsomstandigheden leidt tot een geringe discrepantie, dit in tegenstelling tot het effect op de discrepantie van de minder direct wa a neembare arbe1dsomstandigheden;

- de geringe mate van overeenkomst tussen de beoordeling van materiële en immatertële arbeldsinconventënten;

- veel 1tems hebben een goede convergente validitelt. Ondanks de (soms hoge mate van) interrelatles tussen de beoordelingen van een beoordelaarscategorle, blijken de nodige items over een goede convergente validitelt te beschikken.

- het gebrek aan hoge Intercorrelaties tussen bepaalde, materiële arbeldsomstandighedenitems. Deze zouden wel gevonden moeten $z i j n$ indien arbeldssituaties zonder meer als slecht en veel hinder-veroorzakend worden beoordeeld. 
Nu de veronderstelling van de meting van een systematische vertekening (bias) nilet houdbaar is gebleken, is het mede gezien de analyses van de abstracte discrepantiematen aannemelijk dat de gebruikte discrepantlematen reële organisatiekenmerken vormen. Dit blijkt te meer uit het felt dat de variantie in de discrepantievariabelen voor een zeer groot deel verklaard wordt door andere organisatiekenmerken. Bovendien wordt deze aanname nog versterkt door de positieve relatie tussen de discrepantiemaat en bepaalde organisatiekenmerken, terwijl de relaties tussen de betreffende organisatiekenmerken onderling negatief kunnen $z i j n$. De organisatlevariabelen leveren derhalve een eigen bijdrage aan de verklaring van de grootte van de geconstateerde discrepantie. Bovendien blijken de organisatiekenmerken, die een samenhang vertonen met de discrepantievariabelen, theoretisch goed interpreteerbaar te $z i j n$ en in grote $11 j$ nen de uitgesproken verwachtingen te dekken, althans daar niet mee in strijd te zijn. Waren de gevonden relaties van elke logica gespeend en intern tegenstrijdig geweest, dan zou dit een aanleiding kunnen $z i j n$ te veronderstellen dat de betreffende discrepantiescores niet meer dan op basis van toeval tot stand gekomen somscores zijn.

\subsubsection{Implicaties voor organisatie-onderzoek}

Nu aangetoond is dat de mate van discrepantie een organisatiekenmerk is, volgt de vraag welke implicaties een dergelijke bevinding heeft voor het organisatie-onderzoek in zijn algemeenheid. De hoge mate van convergente validitelt van een groot aantal items impliceert dat bij onderzoek, gericht op vergelifkingen over organisaties heen (Philipsen, 1969a; RIs, 1978; Nijhuis en Soeters, 1982), veelal volstaan kan worden met slechts én enkele categorie referenten/beoordelaars als informatiebron. Een beperking geldt daarblj voor items, die een ultdrukking zijn van negatleve (neven)effecten van een gevoerd beleid, zoals dit het geval kan $z 1 j n$ bij reorganisaties en het voorkomen van ontslagen, maar ook bijvoorbeeld bij geconstateerde neveneffecten van automatisering, zoals functleverenging en verhoging arbeldstempo.

Een tweede constatering is dat de items die een operationalisering vormen van meer geestelijk belastende werkomstandigheden, minder eenduidig blijken te zijn dan die van de meer materieel belastende werkomstandigheden. Duidelijk is dat in de toekomst verdere instrumentontwikkeling ook op itemniveau noodzakelifk $1 \mathrm{~s}$. Voor de interpretatie van onderzoek, gedaan over organisaties heen, waarbij een interview heeft plaatsgevonden met éen enkele 
categorle beoordelaars (een representatieve steekproef van werknemers of personeelszaken, personeelsvertegenwoordiging of het management) geldt dat globaal dezelfde resultaten bereikt zullen worden. Zeker geldt dit voor de hinder van de bestaande materielle en immaterlële arbeldsomstandigheden, indien de betreffende items gesommeerd worden tot een soort kwallteit-van-de-arbeld-score. ofschoon over het concept 'kwaliteit-van-de-arbeid' in de 11 teratuur weinig eenduidigheld lijkt te bestaan (Huijgen, 1980; KrIjnen, 1980; De Sitter, 1980; Fortuin en Vreeman, 1981; Vreeman, 1982) is het opvallend dat over de kwaliteit van de materielle arbeldsomstandigheden door alle groepen in een organisatie -management, personeelszaken, personeelsvertegenwoordiging, werknemers- een gelljksoortig referentiekader gehanteerd wordt. Ook al versch 11 en de absolute waarden van de beoordelingen, toch zijn de beoordelingspatronen over organisaties heen gelijkvormig. Een derde constatering is dat, indien onderzoek plaatsvindt binnen een enkele organisat1e, verschillen tussen de beoordelingen van alverse groepen binnen de organisaties niet uitgesloten kunnen worden. Zeker geldt dit voor de ervaren zwaarte van bepaalde activiteften en van het beleid dat gevoerd wordt of van de hinder die ervaren wordt van verschillende arbeidsomstandigheden. Deze verschillen $z 1 j n$ slechts beperkt in onvang tussen de beoordelingen van het management en die van personeelszaken. De verschillen worden groter bij de vergelijking met de beoordelingen van de werknemers of met die van de personeelsvertegenwoordiging. overigens blijken ook tussen deze twee laatsten de nodige verschillen te constateren.

Bij onderzoek binnen éên bedriffsorganisatie, bijvoorbeeld naar de effecten van automatisering, naar het vobrkomen van ontslagen, of naar de beoordeling van de arbeldsomstandigheden, of in het algemeen naar de betekenis van organisatiekenmerken, blifft het raadzaam om met meerdere categorleën beoordelaars te werken. De selectle van beoordelaars hangt daarbij af van het gestelde probleem. Ten aanzien van hun beoordelingen dient dan ook met name gekeken te worden naar de verschillen in beoordeling, juist met het oog op -uit de betreffende analyse resulterende- interventies.

Deze conclusies sluiten ook aan bif andere recente benaderingen van de organisatle als een door onderhandelingen tot stand gekomen structuur, waarbij permanent sprake is van de vorming van coalities om eigen machtsposities te verbeteren. Om dit onderhandelingenspel beter te kunnen begrijpen is kennis van verschillende beoordelingen en van discrepanties tussen deze beoor- 
delingen noodzakel1jk (vergelljk: Bacharach en Lawler, 1980). Ditzelfde geldt eveneens voor het begrijpen van conflicten tussen groepen in organisaties. Verschillen in beoordelingen en in verwachtingen (grote discrepantles) vormen lmmers allicht een goede voedingsbodem voor het ontstaan van conflicten.

8.2.3. Implicaties voor interventies

Dat voor bepalde groepen in de arbeidsorganisatie specifieke arbeldsomstandigheden belangrijker zijn dan voor andere groepen blijkt onder andere uit hun verschiliende reacties op het iten: - In welke mate ondervindt $U$ (-en de werknemers) hinder van stank?

In tegenstelling tot de resultaten bij de overige arbeidsomstandighedenitems, blifkt de werknemersbeoordeling daarover een duidelijk negatiever beeld te geven dan de beoordeling door de drle andere groepen. Een mogelijke verklaring zou kunnen zijn dat stank op zich niet zonder meer direct gezondheidsbedreigend is en daarmee voor de gefnstitutionaliseerde groepen beoordelaars minder belangrijk is.

Gezien de grote mate van discrepantie ten aanzien van de effecten van automatisering is kennls over deze oordelen ten aanzien van die effecten eveneens belangrijk om de specifieke reacties van werknemers adequat te kunnen inschatten bij de implementatie van nieuwe automatiseringssystemen. Dit geldt des te sterker gezien de geringe mate van overeensteming tussen het voorkomen van reorganisaties en van het aantal ontslagen dat plaats heeft gevonden. Indien over dergelijke organisatieaspecten, in diverge sectoren van een arbeidsorganisatie, duidelijk verschillende percepties bestaan en de centralitelt daarvan verschillend 18 , dan zal daarvan grote invloed op de reacties ten aanzien van nieuwe interventies, implementaties, reorganisaties te verwachten zijn. Ook hier geldt dat naast inzlcht in de inhoud van de beoordeling (de mate waarin lets voorkomt) julst ook het inzicht in dergelijke discrepanties van groot belang is on te begrifpen waarom de een of andere partij een interventle positief danwel negatief bejegent en om derhalve vooraf een inschatting te kunnen maken van de effecten van interventies.

Zoals uit de relatie tussen verzuimduur en de mate van discrepantie tussen management en personeelsvertegenwoordiging kan worden afgeleid behoort het tot de reële mogelijkheden, dat ondanks gemiddelde lange ziekteduren toch niet tot interventie wordt overgegaan, omdat een dergelijke lange zlekteduur acceptabel wordt 
bij 'slechtere' arbeldsomstandigheden (bedrijfsklimaat). De bereldheld tot interventies en het succes ervan wordt mede bepaald door de mate warin bijvoorbeeld lange ziekteduren als nietgeaccepteerd organisatiegedrag een probleem vormen. In een gegeven rullsituatie (arbeldsomstandigheden versus ziekteduur) kan deze berelidheld en de kans op succes gering $z i j n$.

Tenslotte kan de discrepantiescore een goede indicator vormen voor het sociale klimat in de arbeldsorganisatie. Een grote discrepantie duldt erop dat de informatie van beneden naar boven en omgekeerd minder betrekking heeft op de door de ander ervaren arbeldsomgeving, hetgeen allicht kan leiden tot inadequate reacties. Een hoge discrepantie kan ook het effect zijn van (sluimerende) conflicten in een werksituatie. Bovendien zal een dergelifke sltuatle zelf ook weer sneller lelden tot conflicten, die bovendien eerder kunnen escaleren. Het zijn mede dit soort processen die, ten gevolge van discrepante percepties binnen organisaties, ertoe kunnen leiden dat veranderingsprojecten, c.q. interventles binnen de arbeidsorganlsatie resulteren in nietverwachte en soms zelfs destructieve gevolgen.

Voor de keuze van goede interventies ter oplossing van een probleem in een organisatie is een analyse van de mate van discrepantie van de betrokkenen ten aanzien van dat probleem derhalve minstens even belangrijk als een analyse van de aard en zwaarte van het probleem.

Uit dit onderzoek blijkt opnieuw dat bij organisatie-advieswerk niet volstaan kan worden met een top-down strategle, maar dat daarbij vanaf het eerste moment de beoordelingen van organisatiekenmerken van de versch11lende categorleën personeel betrokken dienen te worden (zle ook: Bruining en Allegro, 1981; Sopar, 1981; Algera en Koopman, 1983).

8.3. Bronnen van discrepantie

Zoals deels reeds eerder is aangegeven (hoofdstuk 3) zijn ten aanzien van de angetoonde discrepanties de volgende bronnen te signaleren:

a. verschil in referentiekader.

Dit blijkt uit het felt dat veelal een hoge intercorrelatie tussen beoordelaars ten aanzien van dezelfde items gepaard gaat met verschillen in gemiddelden. Met andere woorden: over verschillende werksituaties heen blijken de beoordelingen consistent, werk- 
situaties die door de ene beoordelaar als hinderlijk worden beschouwd, worden dat ook door andere beoordelads. Ten aanzien van wat (in deze werksituaties) als hinderlijk ervaren wordt blijken zij echter een verschillend basisvergelijkingsniveau te hanteren. Zo blijkt 'geestelijk zwaar werk' een over de organisaties heen, betrouwbare, d.w.z. een min of meer eenduldige, maat te $z 1 j n$, terwijl dit niet geldt voor de items die aspecten van de immateriële belasting meten. Ook blifkt dit verschil in referentiekader uit het feit dat de elgen positie in de organisatie zulk een belangrijke rol speelt bij de beoordeling van de items.

b. polarisatie en selectie-effecten.

De verklaring van de consistentie in de afwijkingen tussen de waarderingen van de personeelsvertegenwoordiging en die van de werknemers moet gezocht worden in de polarisatie die in de organisatie plaats heeft tussen de geinstitutionaliseerde groepen. Deze polarisatie komt dan voort uit de houding om de elgen (onderhandelings-)positie te versterken in de onderlinge contacten tussen deze groepen. Door een regelmatig overleg zonder meer worden de onderlinge tegenstellingen nlet opgeheven, maar bestaat zelfs de kans dat zij verscherpt terugkomen, indien beide partijen in dit overleg dusdanige onderhandelingsposities innemen dat de elgen positie en de eigen eisen zo pregnant mogelijk verwoord kunnen worden. Het management zal proberen aan te tonen dat de arbeldsomstandigheden in vergelijking met elders goed of althans niet uitgesproken slecht zijn; de personeelsvertegenwoordiging zal de tegengestelde strategle volgen (vergelijk: Festinger, 1958). Onder de druk van de communicatie en confrontatie treedt verharding van de eigen positie op, waardoor de discrepantle toeneemt. In deze is een parallel met de communicatiepatronen, zoals deze in de politieke besluftvormingsprocessen plaatsvinden, herkenbaar. Hler 1igt een onderzoeksterrein braak voor de politieke peychologie.

Naast dit polarisatie-effect kan tevens een selectie-effect opgemerkt worden. Leden van de personeelsvertegenwoordiging zullen veel meer gericht zijn op negatieve arbeldssituaties dan de 'gemiddelde' werknemer (vergelljk: Teulings, $1981 \mathrm{~b}$ ).

\section{c. communicatiestructuur.}

Uit de analyse van de discrepantlevariabelen blifkt, dat de structurele opbouw van de organisatie de discrepantie beinvloedt. De hoge mate van overeensteming, die overigens valt te constateren ten aanzien van kenmerken of aspecten van organisatiebeleid, 
die waarneembaar vast1lggen in de organisatie (werkoverleg, beoordelingssystemen, werktijdverkorting, etc.), duidt op de tendens dat binnen de organisatie de kennls over de organisatiekenmerken sterker $1 \mathrm{~s}$ naarmate de zichtbaarheld van die kenmerken groter 1s. Varlabelen die verandering in werkbelasting meten of varlabelen die een ultdrukking vormen voor de hinder van immaterièle arbeldsinconvenlënten, blillken in mindere mate tot overeensteming te leiden.

Indien gekeken wordt naar de meer abstracte discrepantiemaat -berekend per organisatie- dan is het opvallend dat een aantal variabelen, die theoretisch zouden moeten leiden tot een vermindering van de discrepantie deze juist blijken te vergroten. De indruk bestaat dat organisaties met een platte organisatiestructuur en met minder werkstructureringsactiviteiten een geringere mate van discrepantie vertonen. Dit kan verklaard worden vanult de veronderstelling dat in zeer bureaucratische, starre organisaties de organisatieaspecten zo vast liggen dat daarover geen verschil kan ontstaan (slechts beperkte communicatie mogelijk). In combinatie met het voorafgaande aspect lijkt dit erop te duiden dat in organisaties waar meer overleg plaatsvindt, deze communicatie de mogelijkheld biedt tot onderhandelingen en tot divergerende stellingnames. Als zodanig is een interessante parallel te trekken met de machtsafstandsreductie-theorle van Mulder. Een van de uit deze theorie afgeleide stellingen is, dat in het geval van een te grote machtsafstand participatie eerder leidt tot een vergroting dan tot een verkleining van deze machtsafstand (Mulder, 1977). Met betrekking tot communicatie en discrepantie leidt een herformulering daarvan tot de stelling: een vergroting van de communicatle en van de intraorganisationele onderhandelingsterreinen leidt eerder tot grotere dan tot kleinere verschillen in overeenkomst tussen de betrokken "onderhandelaars".

Een tweede parallel die ten deze getrokken kan worden $1 \mathrm{~s}$ die met de ontwikkeling van de divergentie in de wetenschap. Whitley (1982) stelt dat de mate van divergentie in de ontwikkeling van bepalde wetenschappen inclusief de psychologie het effect is van de organisatie van het onderzoek in die wetenschap, tot uitdrukking komend in diffuse Interpretatieschema's, een veelheid van conflicterende theorleën e.d.

d. statistische fouten.

Ten aanzlien van de beoordeling van aspecten van de arbeldsorganisatle en -situatie blijken de verschillende beoordelaars systematisch onder of boven de waardering van andere beoordelaars te 
zitten. Hierbif is eerder sprake van verschillen in optiek en waardering dan van statistische fouten. Bij beschouwing op facevalidity van de beoordelingen van de arbeidsomstandighedenitems valt het op dat de meest positleve beoordelingen komen van het management en van personeelszaken, de meest negatieve beoordeling door de personeelsvertegenwoordiging, terwijl de werknemersscore daar tussen in 1igt. Opvallend daarbif is dat de gemiddelde werkremersscore positiever is dan het oordeel van hun vertegenwoordigers in de ondernemingsraad of in een anderssoortige personeelsvertegenwoordigingsorgaan.

e. vergroting van de eigen machts of invloeds positie.

De invloed van de rechtspositioneel minder machtigen in een organisatie kan versterkt worden door de eigen machtsbasis te vergroten. De machtsverhoudingen in een organisatie hebben ten aanzien van veranderingen een sterk afhankelijkheldskarakter: de een kan slechts aan invloed winnen door de macht van de ander af te breken (Bacharach en Lawler, 1980). In een situatie met weinig gemeenschappel1jke belangen geschiedt dat onder andere door de benadrukking van het onrecht dat de werknemers (slechte arbeldsomstandigheden) of de werkgever (aanval op zijn bedriff) aangedaan wordt. Hierbij speelt ook antlciperende verdediging mee op de aard van een te verwachten aanval, alvorens deze gelanceerd is.

Een laatste facet dat hier genoemd moet worden is de geringe mate van overeenstemming tussen de beoordelingen van de immateriële items onderling en de -vooral bij het management en personeelszaken- negatieve relatie van veel van deze 1 tems met die betreffende materiëe1-bezwarende arbeidsomstandigheden. Dit kan verklaard worden door het ontbreken van eenduidigheid van deze concepten, gezien het gebrek aan een convergente validiteit. Een andere oorzaak daarvan 1 ijkt te $z i j n$ dat met name ten aanzien van deze items de eigen werkzaamheden als maatstaf worden genomen en van daaruft andermans taken beoordeeld worden. Het werk van personeelszaken en management is objectlef minder zwaar wat betreft de materiële inconveniënten. Vanuit hun positie is het begrijpe$11 \mathrm{jk}$ dat $z i j$ geneigd $z i j n$ om productiewerkzaamheden veelal als geestelijk minder zwaar te kwalificeren. Om de status van het efgen werk als geestelljk 'zwaar' te kunnen handhaven projecteren zif het complement daarvan negatief op het overige werk, wat betreft datgene wat zif in hun eigen werk het zwaarst vinden. Lichamelijk zwaar en inspannend werk wordt dan ook al gauw dom werk genoemd, ook al gaat eentonlg en zwaar werk eerder gepaard 
met overbelasting dan met onderbelasting (Lev1, 1981). Met deze discrepantie wordt derhalve mogelijk het blauwe-boorden-werk in witte-boorden-maten gemeten.

Tenslotte dient opgemerkt te worden dat de individuele klaaggenelgdheld geen bron van systemat1sch afwljkende oordelen blijkt te $z 1 j n$.

8.4 . Afslufting

De meting van discrepantle betreffende de beleving van en kennis over een organisatie kan, zowel ten aanzien van fundamenteel toegepast onderzoek, als voor de praktifk van het organisatieadvieswerk, vruchten afwerpen. Ter aanvulling op de eerder genoemde mogelijkheden zullen hier een drletal practische toepassingsmogelijkheden worden vermeld:

a. Discrepantie kan het_inzicht_in de_organisatiestructuur_ver-

Zowe1 concrete discrepantle op itemniveau als een abstracte totaaldiscrepantie bleden mogelijkheden voor inzicht in de wifze waarop de organisatie doorwerkt op het individu en organisatieprocessen gestalte krijgen in individuele waarnemingen. Dat discrepantie tot op heden nauwelijks object van onderzoek is geweest, moet geweten worden aan het felt dat bij de bestudering van de organisatles met name het management en personeelszaken als informatlebronnen fungeren. Uit het gepresenteerde materlaal b11jkt dat met name in nlet-industriële organisaties de discrepantle tussen deze belde groepen hoger is. Middels discrepantieanalyses kan de communicatiestructuur beter geanalyseerd worden, omdat daarbif nlet alleen van belang is $6 f$ een boodschap is overgekomen, maar ook hóe deze is aangekomen en verwerkt. Vanuit een dergelijke verwerking is het gedrag van werknemers in organisaties beter interpreteerbaar, hetgeen met name voor organisatieadvisering belangrifk kan zijn. Het onderscheld tussen belevingsbeeld, dat wil zeggen de visie van een informant/respondent op het functioneren van de organisatie en feitenbeeld, zoals bijvoorbeeld beschreven door Malotaux (1982), 1ijkt gezien deze bevindingen minder goede mogelifkheden te bieden dan de benadering middels discrepantlebepaling. Uit de discrepantieanalyse wordt namelijk duidelijk dat ook ten aanzien van het feitenbeeld 
zeer grote verschillen kunnen bestaan.

b. Discrepantie als maat voor het sociaal k11maat.

Het sociale klimaat in een organisatie wordt vaak als een belangrijk organisatiekenmerk beschouwd (Schnelder en Relchers, 1983). De meting daarvan stult echter op problemen wat betreft de operatlonaliseerbaarheid. Discrepantiematen zijn in deze aan te merken als een indicator voor soclale klimaataspecten en als een vorm van operationalisatie daarvan.

c. Discrepantie als signaal voor een weerstandsmaat bij interventies.

Indien geconstateerd wordt dat in een organisatie een hoge mate van discrepantie bestaat tussen de opvattingen van bifvoorbeeld personeelszaken en personeelsvertegenwoordiging, dan vraagt deze bevinding om interventies. Bif een hoge mate van discrepantie 18 immers te verwachten dat deze lefdt tot

a. een hogere mate van polarisatie in overlegsituaties, en

b. een hoger aantal conflicten, vanwege de verschillen in perceptie.

Nadat in deze studie, zij het op een verkennende wijze, een onderzoek is gedaan naar de aanwezigheld van en oorzaken voor discrepantie in een arbeidsorganisatie, moet geconstateerd worden dat veel verbanden en veronderstellingen genoemd $z i j n$ die om nader onderzoek vragen. Dergel1jk onderzoek $11 \mathrm{jkt}$ onder andere zeer gewenst ten aanzien van de volgende aspecten:

- de relaties tussen communicatie en discrepantie;

- de relatie tussen conflicten, de escalatie van conflicten en discrepantie;

- de ontwikkeling van machtsverhoudingen in arbeldsorganisaties en de invloed daarvan op de communicatiestructuur;

- Invloed van discrepanties op het succes van organlsatieverandering;

- het v66rkomen van onnodige polarisatie in overlegsituaties;

De verklaringen woor de bevindingen in dit onderzoek kunnen bif vervolgonderzoek dienst doen als te toetsen hypothesen. 


$$
-176-
$$


In het kader van een onderzoek naar de relatie tussen organisatiekenmerken en ziekteverzuim $z i j n$ per arbeldsorganisatie (zowel industriële als niet industriële organisaties) interviews gehouden met een drietal categorleën beoordelaars: het hoofd van de productieafdeling, het hoofd personeelszaken en leden van de personeelsvertegenwoordiging. Bij de interviews aan de hand van gestructureerde vragenlijsten ontstond de indruk dat tussen de drie categorieën beoordelaars aanmerkelifke verschillen in de beoordeling van organisatievariabelen aanwezig waren.

Dit onderzoek probeert naar aanleiding daarvan een antwoord te vinden op de volgende vragen:

- Zijn er systematische verschillen tussen de genoemde beoordelaars ten aanzien van verschillende organisatiekenmerken?

- Zo ja, zijn deze verschillen organisatie-afhankelijk, met andere woorden: Wordt de variantie ervan verklaard door andere organisatiekenmerken?

- Zo ja, ten aanzien van welke aspecten treden deze verschillen dan op?

- Waardoor kunnen deze verschillen worden verklaard?

In hoofdstuk 1 wordt ingegaan op afwezigheld wegens ziekte als gezondheidkundig probleem. Geconstateerd wordt dat het ind 1 vidu, afhankelijk van de aard van de aandoening, een grotere of kleinere beslissingsvijheid heeft tot ziekmelding of ziekteduurverlenging. Dit beslissingsproces wordt, naast individuele en maatschappelijke factoren, ook door de arbeldssituatie beinvloed. Dit latste facet is uitgangspunt van deze studle geweest. Belnvloeding van de arbeldssituatle kan derhalve effect resulteren ten aanzien van het percentage verzulimalagen.

In hoofdstuk 2 worden enkele kenmerken van de aan dit onderzoek deelnemende bedrijven beschreven. Op basis van eerder onderzoek (Nijhuis en Soeters, 1982), worden de belangrijkste relaties beschreven tussen enerzijds een drietal verzuimindicatoren, frequentie, duur, aanta 1 arbeidsongeschiktheldstoetredingen, en organisatiekenmerken anderzifds.

Organisatiekenmerken kunnen, zo blijkt uit hoofdstuk 3, zowe1 objectief (institutionele benadering) als door middel van vragen11jsten (questionnalre benadering) gemeten worden. In een aantal studies worden meerdere meetinstrumenten naast elkaar gebrulkt. 
D1t geldt met name voor de meting van de individuele taakultroering en van de directe werkomgeving. Het blijkt dat de plaats van beoordelaars in de arbeidsorganisatie van lnvloed kan zijn op de beoordeling van deze taakkenmerken.

Dergelifke versch1llen bestaan mogelifk ook bif de beoordeling van organisatiekenmerken. Oorzaken voor deze verschillende beoordelingen kunnen gevonden worden in de verschillende posities van de beoordelaars, in het communicatiepatroon of in een systematische vertekening.

Aangegeven wordt hoe de over-all-discrepantie per organisatie berekend kan worden en tevens hoe zowel deze over-al1-discrepanties, als verschillen op de afzonderlijke items geanalyseerd zullen gaan worden.

In hoofdstuk 4 wordt aangegeven door welke organisatievariabelen de discrepantievariabelen mogelijk beinvloed worden. De betreffende organlsatlevarlabelen zijn ingedeeld in een vifftal groepen: algemene organisatiekenmerken ( $0 . a$. aard van het arbeldsproces, grootte), aanwezigheid afdeling personeelszaken, personeelsbeleid, technologische ontwlkkelingen en interne overlegstructuren. Bovendien wordt in dit hoofdstuk aangegeven welke samemhangen verwacht worden tussen deze variabelen en de discrepantlescores.

Hoofdstuk 5 toont de analyse van de discrepantiemat per organisatie.

De discrepantie tussen management en het hoofd personeelszaken blifkt groter, naarmate:

- de materiele werkbezwaren minder belastend $z 1 \mathrm{jn}$;

- het arbeldsproces meer dienstverlenend is;

- het financleel risico bij zlekte voor de organisatie hoger is;

- de organisatiestructuur meer hiërarchisch is;

- het percentage 55-64 jarige werknemers hoger is;

- het personeel meer afkomstig is ult verstedelijkte gebleden.

De discrepantle tussen management en personeelsvertegenwoordiging blijkt groter te $z 1 j n$, naarmate:

- de materiële werkbezwaren minder belastend zijn;

- de 1 materiële werkbezwaren meer belastend zijn;

- meer werkstructureringsactiviteiten plaatsvinden;

- de personeelsvertegenwoordiging minder gestructureerd is;

- de organisatlestructuur meer hiërarchisch is opgebouwd. De discrepantie tussen het hoofd personeelszaken en de personeelsvertegenwoordiging blijkt groter te $z i j n$, naarmate: 
- er meer werkstructureringsactivitelten plaats hebben;

- het personeel meer afkonstig is uit verstedelijkte gebleden.

De discrepantievariabelen blijken weinig extra's bif te dragen aan de analyse van de verzuimproblematiek, zij het met ultzondering van de discrepantie tussen management en personeelsvertegenwoordiging; deze blijkt kleiner te zijn, naamate de ziekteduur langer is.

De positie van de beoordelaar in de organisatie blifkt een sterke Invloed te hebben op de beoordeling van een aantal organisatiekenmerken (hoofdstuk 6). Zo worden verschillen in gemiddelden gevonden ten aanzien van onder andere:

- het vórkomen van gedwongen ontslagen;

- de hinder die ondervonden wordt van zowel materiële, als immateriële arbeldsomstandigheden;

- de aanwezigheld van beoordelingssystemen.

over sommige andere kenmerken (bijvoorbeeld het vo6rkomen van reorganisaties) blijkt geen overeenkomst te bestaan.

We 1 blijken de correlaties op eenzelfde 1tem over verschillende beoordelaars vaker significant met een hogere mediaanwaarde, dan de correlaties tussen verschillende items binnen én beoordelaar of tussen beoordelars.

Ten aanzien van de beoordeling van een aantal materiële en immateriële arbeldsomstandighedenitems (lawaal, tocht, vull, koude e.d.) blijkt de personeelsvertegenwoordiging aanmerkelijk vaker van oordeel dat een groter deel van het personeel daarvan hinder ondervindt, dan het management of het hoofd personeelszaken. De beoordelingen van deze drie categorieën beoordelaars: management, personeelszaken en personeelsvertegenwoordiging $z 1 \mathrm{fn}$ eveneens vergeleken met een gemiddelde werknemersscore op dezelfde items. De werknemers blijken ten aanzien van de beoordeling van de materiële arbeidsomstandigheden veelal een positle in te nemen tussen het hoofd personeelszaken en de personeelsvertegenwoordiging in. Ten aanzien van de immateriële arbeldsomstandigheden $11 \mathrm{gt}$ de gemiddelde werknemersscore het laagste van alle beoordelaars, hetgeen getuigt van een geringe mate van hinder.

In hoofdstuk 8 wordt aangegeven dat de gevonden verschillen in beoordeling verklaard kunnen worden door aspecten die samenhangen met de positie van de beoordelaar in de organisatie, te weten: 
- verschil in referentiekader, door verschil in positie en belangen,

- polarlsatie-effect en een versterking van de eigen positie in de organisatie; veel van de gemeten organisatiekenmerken vormen onderwerp van overleg tussen de geinstitutionaliseerde groepen In de arbeldsorganisatie,

- communcatiestructuur, welke mede wordt belnvloed door de organisatie van de arbeld.

Tevens wordt aangegeven hoe deze bevindingen implicaties kunnen hebben voor zowel het onderzoek blnnen organlsaties als voor interventies. Bij de beoordeling van organlsatiekenmerken blijkt, gezten de bevindingen van het in dit proefschrift beschreven onderzoek, niet volstaan te kunnen worden met een top-down strategle, maar dient bij organisatieonderzoek met name ten behoeve van interventles binnen de organlsatie, de verschillende personeelscategorfeën in de organisatie expliclet te worden betrokken. 


\section{Summary}

Based on a study on the relationships between working conditions, organizational characteristics, and absenteelsm due to illness, the present study describes the measurement and the ratings of organizational characteristics on behalf of intervention strategies.

In connection with a preceding investigation on the relationships between organizational characteristics and absenteelsm due to iliness, the present study is based on interviews conducted with three categories of raters $\mathbb{i n} 23$ industrlal and 19 non-industrial/service organizations.

The three categories of raters comprise of: Managers of production sections, heads of personnel departments, and members of the workers' councils.

The interviews contained mainly precoded questions. On the basis of those interviews the impression was formed that there would exist considerable differences between the rating scores of the three categories of raters.

On the basis of this impression, this dissertation describes the research that was performed to answer the following questions:

a. Are there any systematic differences between the rating scores with respect to organizational characteristics;

b. On what organizational characteristics do these differences exist and what are the reasons for these differences;

c. Are those differences dependent on specific organizational features, or in other words, could the variance in rating scores be explained by organizational structures.

Chapter 1 describes the problem of absenteelsm due to 111 ness. Although each individual possesses a certain freedom with respect to his decision to be absent, or to remaln absent, due to $111-$ ness, this decision is conditional upon many factors. The most important of these are: Kind of 111ness, particular individual and social factors, organizational characteristics, and preva11ing working conditions.

Now, changing the latter working conditions might reduce the percentage of sick leave days. Before this object could be achieved, however, appropriate interventions will have to be based on valid measurements of these conditions, or other relevant organizational characteristics. 
In chapter 2 some organlzational characteristics (1ndustrial or service area, number of employees, etc.) of the organizations that were studled are described. Results of the preceding study (N1jhuls soeters, 1982) showed particular relationsh1ps between three Indicators of slck leave (1.e. frequency and duration of sick leaves, and disablitty according to the Disability Act), and some organizational characteristics (e.g. influence of: Heavy physical work, poorly qualifled labour, absence of soctal support, financlal condition of the organization, and quality of personne1 management).

Chapter 3 describes how the differences between the raters will be analyzed. Organizational characteristics can be measured by an institutional approach (objective measures) or by interviews or questionnaires. In some studles several levels of measurement are used at the same time (triangulation). This is especially the case with respect to measurement of task performance and of characteristics of the immediate work surroundings.

Such studies have polnted out that the position of the raters in the labour or service organization to a large extent may influence the particular aspects to be measured. Those fundamental differences might, in like manner, exist in relation to organizational characteristics. These differences between categorles of raters, then, can be the result of specific positions of raters in the organization, of communication patterns, or due to systematic bias.

For each organization, these measures of difference were constructed as follows:

a. One measure of difference between the ratings of management representatives and heads of personnel departments;

b. One between the ratings of management representatives and members of the workers' counc11s;

c. One between the rating of heads of personnel departments and members of the workers' councils.

Chapter 4 describes in what manner organizational characteristics may be Influenced by these measures of difference. The 15 observed organizational characteristics are divided into five subgroups : 
a. General organizational characteristics (e.g. size, hierarchy, kind of production process);

b. Structure of personnel departments;

c. Structure of internal participation networks;

d. Personnel management;

e. Technological developments in the organizations.

The relationships between the measures of difference and the working conditions are analyzed separately.

In addition, the kind of hypothesized relations between these organizational characteristics and the measures of difference are described.

Chapter 5 provides an analysis of the measures of difference in organizations. The measures of difference between the ratings of management representatives and heads of personnel departments increase, when:

- Physical working conditions are less severe;

- Financial costs of sick leaves for the organlzations are higher;

- Organizational structure is more hierarchical;

- The percentage of elderly employees (55-64 years) is larger, and

- More workers come from urbanized regions.

Differences between the ratings of management representatives and members of the workers' councils increase, when:

- Physical working conditions are less severe;

- Immaterial working conditions cause more hindrance;

- More job reform activities are carried out;

- Workers' counclis are less structured, and

- Organizational structure is more hierarchical.

Differences between the ratings of heads of personnel departments and members of the workers" councils increase, when:

- More job reform activities are carried out, and

- More workers come from urbanized regions.

The discussion of these findings resulted in the following general conclustons:

a. When working conditions are notably and perceptually more severe, agreement between different categorles of raters is better;

b. Agreement between categories of raters is influenced by the personnal background of the employees. 
These measures of difference contribute only slightly to an explanation of the frequency and duration of absenteeism due to 111ness. The difference in ratings between management representatives and members of the workers ' counc1ls turned out to be negatively related to the mean duration of the sick leaves.

The position of the raters in the organization bears a strong influence on the judgement of some specific organizational characteristics.

Chapter 6 describes differences in means of judgements with respect to the following terms. These are, among others:

- Occurrence of dismissal in the organization;

- Hindrance caused by physical and immaterial working condtions;

- Presence of a system of personnel judgement.

Agreement between raters could not be demonstrated concerning some other characteristics (e.g. occurrence of reorganizations). It is clear that correlations between ratings on a single item are more frequently significant than the correlations between different 1tems within one category of raters, or between raters.

Chapter 7 describes the fundamental differences in ratings on working conditions between categorles of raters in the organizations. One of the major findings is that members of the workers' counc1ls judge that a major part of the personnel appears to be hindered by a multitude of working conditions, more often than other raters do. Comparisons between the ratings mentioned ear$11 e r$ and those from a representative sample of employees are described. Employees' ratings on the physical working conditions are positioned between ratings of the workers' councils and those of heads of personnel departments. Employees" ratings turned out to be low (1.e. Indicating least hindrance) on immaterlal working conditions.

So $f a r$, chapter 7 as well as chapter 6 described the findings concerning the positive agreement in rating patterns on the $s$ ame items using, among other measurements, the multitrait-multimethod approach. On the other hand, there is much less agreement (on means of ratings) between raters within a single organization. It is concluded that in comparative organizational research, it is often adequate and efficlent to perform research with a single category of raters. In investigations alming at acquiring knowledge on organizational functioning within a single organization, one category of raters will not suffice. 
That is, less agreement between raters was found on the following issues:

a. Changes in work organization (reorganization, automation, dismissal);

b. Immaterial working conditions (ambiguity, variety, autonomy, social relations).

In chapter 8, the overall conclusions of this study are formulated. The findings from this study are explained from the perspective of the various positions of raters in the organizations. The most important conclusions pertain to:

a. Differences in frame of reference, caused by position and interests;

b. Polarization effects and increasing influence of own position within the organization. That is, the majority of the organizational characteristics mentioned are subject to bargaining between institutionalized groups in the organizations;

c. (With respect to communication patterns): When organizational structures are more formalized, more hlerarchical, and more changes in tasks occur, there are more differences between categories of raters.

Based on these findings and conclusions, Implications for appropriate interventions in organlzations are mentloned. In acquiring organizational information on change processes, knowledge about differences between varlous rating categorles will be of great importance. 


$$
-186-
$$




\section{Literatuur}

ALDERFER, C.P., Convergent and discriminant validation of satisfaction and desire measures by interviews and questionnalres. J. of applied medical psychology 51: 509-520, 1967.

ALESTALO, M., Patterns of influence in research work: the pro-

blems of autonomy and democracy.

R \& D Management 9: 221-230, 1979.

ALGERA, J.A., Kenmerken van werk.

Swets en Zeitlinger, LIsse, 1981 .

ALGERA, J.A. en P.L. Koopman, Automatisering: ontwerpproces en implementatie (1983). In: Handboek Arbeids- en Organisatiepsychologie, 1980-1983.

ARGYRIS, C., Intervention theory and method. A behavioral sclence view.

Addison-Wesley Reading, 1973.

BACHARACH, S.B. and E.J. Lawler, Power and politics in organizations. The soclal psychology of conflict, coalitions and bargaining.

Jossey-Bass Publishers, San Francisco, 1980.

BACKMAN, C.W., Toward an interdisciplinary social psychology: we"re closer than we think.

Intern rapport $82 \mathrm{~S} 001$, KU N1jmegen, 1982.

BAGCHUS, P.M., H. Kulpers, P.Ch.A. Malotaux en Th. van Haren, Diagnose bij organisatie verandering: een noodzaak.

Kluwer Deventer, 1982.

BAGCHUS, P.M., De noodzaak van diagnose bij organisatieverandering. In: Bagchus e.a.: 7-29, 1982 .

BARTLETT, C.J., What's the difference between valld and Invalid halo? Forced cholce measurement without forcing a choice.

J. of Applied Medical Psychology 68: 218-226, 1983.

BASTELAER, A.M.L. van en W.J.P.A. van Beers, Organlsatlestress en de personeelsfunctionaris.

Swets en Zeltlinger Lisse, 1982 . BECKER, H.S., Sociological work. Method and substance.

Transaction books, New Brunswick, 1977. BEEK, J., Voor een marxistische arbeidssociologie.

Doct. scriptie KU N1jmegen, 1973.

BEHREND, H., Absence and Labour turnover in a changing economic climate.

Occupationa1 psychology 27: 69-79, 1953.

BLAU, P.M., The hierarchy of authority in organizations. American Journal of sociology $73: 453-467,1968$. 
BLOOD, M.R. and C.L. Hulin, Alienation, environmental characterlstics and worker responses.

J. of applied Medical Psychology 51: 284-290, 1967. BOER, E.J., de, F. Verhage en Ch.J. de Wolff (red.), Stress...... Uitdaging en Bedreiging.

Swets en Zeltinger, Lisse, 1983. BORMAN, W.C., The rating of individuals in organizations: an a ternative approach.

Organlzational behavior and human performance 12: 105-124, 1974 .

BORUCH, R.F., J.D. Larkin, L. Wolins and A.C. Mackinney, Alternative methods of analysis: multitralt-multimethod data. Educationa1 and psycholog $1 \mathrm{cal}$ measurements $30: 833-853,1970$. BOUTELLIER, H. en L. Wouda, Progressleve ontwikkelingen in de psychologle.

SUA Ansterdam, 1981.

BREMER, J.J.C.B., Stress als uitdaging of bedreiging. In: Boer e. $a_{\text {. }}: 41-55,1983$.

BRIEF, A.P. and R.J. Aldag, Employee reactions to job characteristics: A constructive replication.

$\mathrm{J}$. of applied psychology 60: 182-186, 1975.

BRUINING, G.R.P. en J.T. Allegro, Organisatie-ontwikkeling. In Handboek voor arbeids- en organisatiepsychologie, 1980-1983. BURINGH, E., Zlekteverzuim en conjuncturur in de Nederlandse textielindustrie $\mathrm{I}$.

Tijdschrift voor sociale geneeskunde 55: 186-189, 1977a. BURINGH, E., Zlekteverzuim en conjunctuur in de Nederlandse textielindustrie II.

Tijdschrift voor sociale geneeskunde $55: 225-228,1977 \mathrm{~b}$. CALDER, B.J., K.M. Rowland and H. Lebleblc1, The use of scaling and cluster techniques in investigating the social structure of organizations. In: Kiliman, Pondy en Slevin: 121-154, 1976.

CAMPBELL, D.T. and D.W. Fiske, Convergent and discriminant validation by the multitrait-multimethod matrix.

Psychological Bulletin 56: 81-105, 1959.

CHADWICK-JONES, J.K., C.A. Brown and N. Nicholson, Absence from work: 1 ts meaning, measurement and control.

International Review of applied psychology: 22, 137-154, 1973.

COOPER, R., Task characteristics and intrinsical motivation. Human Relations 26: 387-413, 1973. 
COOPER, W.H., Conceptual similarity at a source of illusory Halo in Job performance and Ratings.

J. of applied psychology 66: 302-307, 1981 .

CROWTHER, J., Absence and turnover in the division of one company, 1950-1955.

J. of Occupationa1 psychology 31:256-265, 1957.

DESSLER, G., Organization Theory, Integrating structure and behavior.

Prentice Hall Englewood Cliffs, 1980.

DIRKEN, J.M., Het meten van stress in industriële organisaties.

R.U., Groningen, 1967.

DIJCK, J.J.J. van, J.A.P. van Hoof, A.L. Mok en W.F. de $\mathbb{N} 1 j s$, Kwallteit van de arbeid, een sociologische verkenning.

Stenfert Kroese BV Leiden, 1980.

DIJKSTRA, A., Inkrimping van het personeelsbestand in produktiebedrijven en afwezigheld wegens zlekte.

Sociologische Gids 21: 3-15, 1974.

DRAAISMA, D. en P.G.W. Smulders, Ziekteverzuim en het bedrijf Leiden/Antwerpen, 1978.

DRENTH, P.J.D., Onderzoek in de arbeids- en organisatiepsychologie: principes en methoden. In: Handboek Arbeids- en organisatlepsychologie, 1980-1983.

DUNHAM, R.B., Reactions to job characteristics, Moderating effects of the organization.

Academy of management journal 20:42-65, 1977.

DUNETTE, M.D., A note of THE criterion.

J. of applied psychology 47: 251-254, 1963a.

DUNETTE, M.D., A modifled model for test validation and selection research.

J. of applied psychology 47: 317-323, 1963b.

DUNETTE, M.D. (ed.), Handbook of Industrlal and organizationa1 psychology.

Rand McNa1ly Chicago, 1976.

ELIAS, N., H. Martins and R. Whitley, Sclentific establishments and Hierarchies.

Reldel Dordrecht/London: 1982.

ENTERLINE, P., Arbeidsverzuim door ziekte in een aanta1 Westerse 1 anden.

Mens en Onderneming 16: 162-172, 1964. ENTERLINE, P., Social causes of sick absence. Archives of environmental health 12: 467-473, 1966. ETTEMA, J.H., Het model belasting en belastbaarheld. Tijdschrift voor sociale geneeskunde $51: 44-54,1973$. 
FESTINGER, L., A theory of cognitive dissonance.

Evanston ILL, 1957.

FORTUIN, $R$. en $R$. Vreeman, Kwallteit van de arbeld, onderzoek en vakbondsbeleld. In: Boutellier en Wouda: 158-173, 1981.

FRESE, M., Occupational socialization and psychological development: An underemphasized research perspective in industrial psychology.

J. of occupational psychology 55: 209-224, 1982 . GOLDTHORPE, J.H., D. Lockwood, F. Bechhofer and J. Platt, The affluent worker: Industrlal attitudes and behavior.

Cambridge University press Cambridge, 1968a. GOLDTHORPE, J.H., D. Lockwood, F. Bechhofer and J. Platt, The affluent worker: political attitudes and behaviour.

Cambridge Unlversity press Cambridge, $1968 \mathrm{~b}$. GOLDTHORPE, J.H., D. Lockwood, F. Bechhofer and J. Platt, The affluent worker in the class structure.

Cambridge University press Cambridge, 1969. GROOT, M.J.W. de, Kwantitatleve benadering van het verzuim door neurose blj Nederlandse fabrieksarbelders.

NIPG Lelden, 1958.

GROSKURTH, P. und W. Volpert, Lohnarbeitspsychologie Berufliche Sozlalisation: Emanzipation zur Anpassung.

Fischer Taschenbuch Verlag Frankfurt a.m., 1975. GUION, R.M., Criterion measurement and personnel judgement.

Personnel psychology, 14:141-149, 1961 .

GUION, R.M., Scoring of content domain samples: the problem of falrness.

J. of applied psychology $63: 499-506,1978$.

HACKMAN I.R. and E.E. Lawler III, Employee reactions to job characteristics.

J. of applied psychology 55: 259-286, 1971 .

HALL, R.H., Organizations: structure and process.

Prentice hall Englewood Cliffs, 1977.

HANDBOEK arbeids- en organisatie psychologie.

Deventer, 1980-1983.

HARTOG, H.H.W. den, Mogelijkheden en beperkingen van werk en gezondheid, projekten bif de rijksoverheid.

Voordracht ARBO-congres Amsterdam: 1982.

HAZEWINKEL, A. Organisatlestructuur en contingentie theorie.

In: Handboek voor arbeids- en organisatie, psychologie: 1980-1983.

HENEMAN, H.G., Comparisons of self- and superior ratings. $\mathrm{J}$. of applied psychology 59: 638-642, 1974. 
HOLZBACH, R.L., Rater blas in performance ratings: superior, self- and peer ratings.

J. of applled psychology 63: 579-588, 1978.

HUIJGEN, F., Kwalitelt van de arbeid in de industriële sector: problemen en achtergronden. In: Dijck, van e.a.: 83-123, 1980.

HULIN, C.L. and M.R. Blood, Job enlargement, individual differences and worker responses.

Psychological Bulletin 69: 41-55, 1968.

HULIN, C.L., Some reflections on general performance dimensions and halo rating error.

J. of applied psychology 67: 165-170, 1982.

HUNTER, J.E. and F.L. Schmidt, Differential and single-group validity of employment tests by race: a critical analysis of three recent studies.

$\mathrm{J}$. of applied psychology 63: 1-11, 1978 .

HULL, C.M. and N.N. Nie, SPSS update.

McGraw-H111 New York, 1979.

ILGEN, D.R. and J.H. Hollenback, The role of job satisfaction in absence behavior.

Organizational behavior and human performance 19: 148-161, 1977.

INKELES, A., Industrial man; the relation of stating to experience, perception and value. In: Landsberger, H.A.: 264-290, 1971.

INKSON, K., R. Payne and D. Pugh, Extending occupational environment: The measuring of organisations.

Occupationa1 Psychology 41: 33-47, 1967.

JENKINS, G.D., D.A. Nadler, E.E. Lawler III and C. Cammon, Standardized observations: an approach to measuring the nature of jobs.

J. of applied psychology $60: 171-181,1975$.

JOHNSON, S.M., P.C. Smlth, S.M. Tucker, Response format of the job descriptive index: assessment of the rellability and validity by the multitrait-multimethod matrix.

J. of applied psychology $67: 500-505,1982$.

JONG, P.H. de, H. Bruinsma, L. Aarts en J.P. Hop, Determinanten van WAO-toetreding; een eerste totalbeeld.

Zoetermeer/Leiden, 1981.

DE JONGH-HYLKEMA, J.T.0., Maatschappelijk verzuim in ciffers.

Tijdschrift voor sociale geneeskunde 51: 215-222, 1973.

KATZ, D and R.L. Kahn, The soclal psychology of organizations.

J. Wlley and Sons New York: 1978. 
KAVANAGH, M.J., A.C. Mackinney and L. Wolins, Issues in managerlal performance: multitralt-multimethod analyses of ratings.

Psychologlcal Bulletin 75: 34-49, 1971 .

KERLINGER, F., Foundations of behavioral research. Holt Saunders London: 1973.

KILLMAN, R.H., L.R. Pondy and D.P. Slevin, The management of organlzation design, Volume II, Research and methodolgy.

Elsevier North-Holland inc. New York, 1976.

KNOWLES, M.C., Organisational Functioning. A behavioural analysis.

Gower Westmead, 1980 .

KOOPMAN, P.L. en A.F.M. Wierdsma, Werkoverleg als communicatiekanaal en als overlegstructuur. In: Handbook arbelds- en organisatie psychology. Deventer, 1980-1983.

KOOPMAN-IWEMA, A.M., Arbeidsomstandighedenwet en overlegvormen.

Voordracht ARBO-congres Amsterdam, 1982.

KOOT, W.T.M., Analyse van organisatiestructuren.

Samson Alphen a.d. Rijn, 1980.

KRIJNEN, G., Kwaliteit van de arbeid in de industriële sector: problemen en oplossingen. In: Dijck van: 107-123, 1980.

KRUIDENIER, H.J., Zlekteverzuim en confunctuur: een beschouwing naar aanleiding van de daling van het ziekteverzuim.

StIchting CCOZ Amsterdam, 1981 .

KRUIDENIER, H.J., De bedrijfsgezondheldszorg en het dalend zlekteverzuim.

Tifdschrift voor sociale gezondheidszorg $61: 110-115,1983$. KUIPER, J.P., Het zal 6nze zorg zijn.

Van Gorcum Assen/Amsterdam, 1975.

KUIPER, J.P., Mensopvatting en gezondheldszorg.

Van Gorcum Assen: 1980.

LANDSBERGER, H.A., Comparative perspectives on formal organdzations.

Little, Brown and co. Boston, 1971.

LANDY, F.J., R.J. Vance and J.L. Barnes-Farre11, Statistical control of halo: a response.

J. of applied psychology $67: 177-180,1982$.

LATERVEER, R., Met andere ogen.

Industriebond NVV Amsterdam, 1972.

LAWLER III, E.E., The multitrait-multirater approach to measuring managerfa1 job performance.

J. of applied psychology 51: $369-381,1967$. 
LEVI, L., Preventing work stress. Addis on Wesley, Reading, 1981.

MALOTAUX, P.Ch.A., Diagnose bij organisatieverandering in de gezondheidszorg. In: Bagchus e.a.: 49-87, 1982.

MANSFIELD, $R$. and R.L. Payne, Correlations of variance in perceptions of organizational climate. In: Pugh and Payne: $149-184,1977$. MARCH, J.G. en H.A. Simon, Organizations. Wiley New York, 1958.

MEER, F.B. van der en R. Schreuder-Peters, Struktuur, proces en verandering in organisaties.

Intern rapport T.H. Twente, 1980. MEER, F.B. van der, Structure, process and change in organizations: a process theory of social interaction.

In: Dynamics of Science Groningen (RU) Twente (TH), Appendix 2: Research Reports: 344-381, 1982.

MERENS-RIEDSTRA, H. , Leven zonder werk; een sociaal-wetenschappelijk onderzoek naar arbeidsongeschiktheid.

(Diss.) Maastricht, 1982.

MINER, J.D. and J.F. Brewer, The management of ineffective performance. In: Dunette (ed.): 995-1029, 1976.

MUCHINSKY, P.M., Employee absenteelsm. A review of the literature.

$\mathrm{J}$. of vocational behavior $10: 316-340,1977$. MULDER, M., Omgaan met macht. E1sevier Amsterdam, 1977. MURPHY, K.R., Difficulties in the statistical control of halo. $J$. of applied psychology $67: 161-164,1982$.

NATHAN, B.R. and R.G. Lord, Cognitive categorization and dimensional schemata: A process approach to the study of Halo in performance ratings.

$\mathrm{J}$. of applied psychology 68: 102-114, 1983.

NAYLOR, J.C., R.D. Pritchard and D.R. Ilgen, A theory of behavior in organisations.

Academic Press New York, 1980.

NEWMAN, J.E., Understanding the organizational structure - job attitude relationship through perceptions of the work envi ronment.

Organizational behavior and human performance 14: 371-397, 1975.

NIE, N.H., C. Hadlai-Hull, J.G. Jenkins, K. Skinbrenner en D.H. Bentr, Statistical Package for the Social Sciences. New York, 1975. 
NIJHUIS, F., Aanzetten tot een psychologie van bewustzijnsvormen binnen de arbeldersklasse. De persoonlijkheld als een zich ontwikkelend systeem binnen de economische, politieke en 1deologlsche maatschappe11jke verhoudingen.

Doctoraal scriptie KU Nijmegen, 1975.

NIJHUIS, F. en J. Soeters, Werk en zlekte. Een onderzoek naar afwezlgheld wegens ziekte en arbeidsongeschiktheld bij 51 industriële en niet-industriële organisaties in Z-Limburg. Maastricht, 1982 .

NIJHUIS, F. en J. Soeters, Zlekteverzulm, arbeidsongeschiktheid en de organisatie van de arbeld.

T1jdschrift voor sociale gezondheldszorg 61: 686-694, 1983 . NIJHUIS, F., Economische achterultgang in bedrijven en ziekteverzuim.

Voordracht NIP-congres Amsterdam, 1983.

NUNALLY, J.C., Psychometric Theory.

New York, 1967.

OLDHAM, G.R., Job characteristics and internal motivation: The moderating effect of interpersonal and individual varlabels. Human Relations 29: 559-569, 1976.

OLSEN, J., Some methodological problems encountered in occupational health research.

Scandinavian J. of Soclal Medicine 9: 19-25, 1981. PATTON, M.Q., Qualitative Evaluation Methods.

Sage Putt Beverly H111s: 1980.

PAYNE, R. and Mansfleld, R., Relationships of perceptions of organizational climate to organizational structure, context and hierarchical position. In: Pugh en Payne: 134-159, 1973. PEETERS, $R$. en $M$. van Sprunde1, De beleving van luchtvervulling door fabrieksarbelders I + II.

T1jdschrift voor Soclale Geneeskunde 58: 412-417, 461-465, 1980 .

PENNINGS, J., Measures of organizational structure: A methodological note.

American Journal of soclology 79: 686-704, 1973. PHILIPSEN, H., Sociale Gezondheldkunde.

Maastricht, z.j.

PHILIPSEN, H., Afwezigheld wegens ziekte.

Wolters Noordhoff Groningen, 1969a.

PHILIPSEN, H., Steekproeven.

LeIden, $1969 \mathrm{~b}$. 
PHILIPSEN, H., De voorwaardelijkheld van algemene uftspraken toegelicht over de samenhang tussen werkvoldoenting en afwezigheld wegens ziekte.

Sociologische Gids 17(1970) 320-333.

PHILIPSEN, H., Levensfase, generatie en zlekteverzuim. De Invloed van belastende levensomstandigheden, mentaliteit en riskante gewoonten op het aantal zlekmeldingen.

Leiden/Maastricht, 1977.

PLUMMER, N. and L.E. Hinkle, Sickness Absenteelsm.

Archives of Industrial Health 11: 218-230, 1955.

POPITZ, H., H.P. Bahrdt, E.H. Jures und H. Kesting, Das Gesel1schaftsbild des Arbeiters.

Mohr Tubingen, 1957.

PORTER, L.W. and E.E. Lawler III, Managerlal attitudes and performance.

Irwin inc. Homewood, 1968.

PRICE, J.L., Handbook of organizational measurement.

Heath and co Lexington, 1972.

PRINS, R. en A.S.P. Velthuijsen, Ziekteverzuimregistratie als soclaal beleidsinstrument.

Stichting CCOZ Amsterdam, 1979.

PROVINCIALE STUURGROEP ARBO-INSTITUUT, Schets voor de oprichting van ARBO-instituten.

Provincie Limburg, 1982.

PUGH, D.S., D.J. Hïckon, C.R. Hinings, K.M. MacDonald, C. Turner and $T$. Lupton, A conceptual scheme for organizational analysis.

Administrative Sclence Quaterly 8: 289-315, 1963.

PUGH, D.S. and R.L. Payne, Organizational behaviour in its context. The Aston programma III.

Saxon House Lexington, 1977.

PUTTEN, M. van, N. Stelnweg en V. Vrooland, Zlekteverzulmbeleid in de praktijk.

Stichting CCOZ Amsterdam, 1982.

RIS, B.G.M., Personeelsbeleid en Zlekteverzulm. Lelden, 1978.

RHODES, S.R., Age-related differences in work attitudes and behavior: a review and conceptual analysis.

Psychological Bulletin 93: 328-367, 1983.

ROSENSTIEL, L. von, W. Molt en B. Rüttinger, Inlelding tot de organisatiepsychologie.

Spectrum Utrecht, 1975. 
ROUWENHORST, W., On onze gezondheld; De rol van gezondheldsvoorlichting - en opvoeding.

Samson Alphen a.d. Rijn, 1981.

SCHEIN, E., Het organlsatleadvies en de manager. De rol van procesconsultatle bij organisatie-ontwikkeling.

Samson Alphen a.d. Rf jn, 1975.

SCHWAB, D.P. and D.W. Wichern, Systemat1c bias in job evaluation and narket wages: Implications for the comparable worth debate.

J. of applied psychology 68: 60-69, 1983 .

SEASHORE, S.E., B.P. Indik and B.S. Georgopowlos, Relationships among criteria of job performance.

J. of applied psychology 44:195-202, 1960.

SEMMENCE, A., Rising sickness absence in Great Britain - A general practitioner"s view.

J. of the Royal College of practitioners 21: $125-146,1971$. SIEGERS, J.J., De invloed van de arbeidsmarktsituatie op de arbeldsongeschiktheid bif mannen.

Soclologische Gids $28: 161-172,1981$.

SIMS, H.R.J.R., A.D. Szilagyl and D.R. McKemey, Antecedents of work related expectancles.

19: $547-559,1976$.

DE SITTER, L.U. de, Kenmerken en functies van de kwalltelt van de arbeld: theoretische overwegingen, actuele problemen en een beknopt 11teratuuroverzicht. In: Dijck, van e.a.: 43-80, 1980.

DE SITTER, L.U., Op weg naar nileuwe fabrleken en kantoren.

Deventer: 1981 .

SMITH, P.C., The problem of the criteria. In: Dunette e.a.: $745-775,1976$.

SMULDERS, P.G.W., De effecten van matregelen om het zlekteverzulm te belnvloeden.

NIPG/TNO LeIden, 1980 .

SMULDERS, P.G.W., Onderzoek en aanpak van het verzuim in een groot Nederlands metaalbedriff en Veranderingskundige conclusies rond verzulm met ervaringen bij een groot metaalbedriff. In: Vrooland (red.): 188-211, 1982 .

SMULDERS, P.G.W., Enlge achtergronden van het dalend ziekteverzuIm.

Tifdschrift voor soclale gezondheidszorg $61: 516-517,1983$. SMULDERS, P.G.W., P. van Leeuwen en W.N. van Nooten, Werkloosheid en zlekteverzuim: theorie en longltudinal onderzoek.

Gezondheld en Samenleving 4: 23-31, 1983. 
SOETERS, J., Na de zlektemelding..... over de behandeling en werkhervatting van langdurig zleke werknemers.

Maastricht, 1983a.

SOETERS, J., Patiënt, gezondheldszorg en langdurige ziekte. Dissertatie Rijksuniversiteit Limburg Maastricht, $1983 \mathrm{~b}$. SOPAR, H. Ph.M., Organisatie verandering: een theoretische beschouwing. In: Handboek voor arbeids- en organisatie psychologie: 1980-1983.

STEERS, R.M. en S.R. Rhodes, Major influences an employee attendance: a process model.

J. of applied psychology 63: 391-407, 1978.

TATSUOKA, M.M., Discriminant analysis. The study of group differences. Selected topics in advanced statistics number 6 . Coronado Driver, Illinois, 1970.

TAYLOR, P.J. and S.J. Pocock, Postwar trends in sickness absence and unemployment in Great Britain.

Lancet 2: 1120-1123, 1969 .

TEULINGS, A.W.M., Ondernemingsgraadspolitiek in Nederland. Een onderzoek naar de omgang met markt en conflict door de ondernemings raad.

Van Gennep Amsterdam, 1981a.

TEULINGS, A.W.M., Ondernemingsraad en achterban.

Tijdschrift voor Agologie 10: 179-199, $1981 \mathrm{~b}$.

TORDOIR W.F., M.M. van der Klauw, C.M.J. van Monen Boekestein, Gezondheidszorg en lange ziekteduren.

Leiden, 1978.

TURNER, A.N. and P.R. Lawrence, Industrlal jobs and the worker: an Investigation of response to task attributes.

Harvard Univer. Press Boston, 1965.

VEEN, P., Organlsatietheorieën.

In: Handboek voor arbeids- en organisatie psychologie $1980-1983,1980 a$.

VEEN, P., Kemmerken van organisaties. In: Handboek voor arbeldsen organisatie psychologie: 1980-1983, $1980 \mathrm{~b}$.

VINNI, K. and M. Hakama, Healthy worker effect in the total Finnish population.

British J. of Industrial medecine 37: 180-184, 1980 . VISSER, A.Ph., De betekenis van de VOEG: enkele gegevens over de begripsvaliditeit.

Gezondheld en Samenleving 4: 177-188, 1983.

VOLPERT, W., Die Lohnarbeitswisrenschaft und die psychologie des Arbeitstätigke1t. In: Groskurth en Volpert: 11-196, 1974. 
VREEMAN, R. (red.), De kwalitelt van de arbeld in de Nederlandse industrie.

SUN N1 Jmegen, 1982.

DE VRIES, G., Sociale orde, regels en de soclologie. Een wetenschapsfllosof 1 sch onderzoek naar theorlevorming in de sociologie.

Me ppel/Amsterdam, 1977.

VROOLAND, V.Chr. (red.), Werk en Gezondheld. Over zlekteverzuim en humanisering van de arbeid.

Samson Alphen a.d. Rifn, 1982.

VAN VUCHT TIJSSEN, J., A.A.J. van den Broecke, N. van Dijkhuizen, H.M.J.K.I. Relche en Ch.J. de Wolff, Mlddenkader en Stress. Een onderzoek naar de problematlek van het middle management. COP/SER 's Gravenhage, 1978.

WEBB, E.J., D.S. Campbell, R. Schwartz and L. Sechrest, Unobtrusive measures. Nonreactive research in the social sciences.

Rand McNally Chicago, 1966.

WEICK, K., The soclal psychology of organizing. Add1son-Wesley Reading, 1969.

WHITLEY, R.D., The establishment and structure of the sciences as reputational organizations. In: Ellas, e.a.: $31-359,1982$.

WILLIAMS, L.K., W.F. Whyck and C.S. Green, Do cultural differences affect workers attitudes?

Industria1 Relations 5: 105-117, 1966.

ZAMMUTO, R.F., M. London and K.M. Rowland, Organization and rator differences in performance appraisals.

Personnel psychology 35: 643-658, 1982.

ZEE, J. van der, De vraag naar diensten van de hulsarts.

Nederlands Hulsartsen Instituut, Utrecht 1982.

ZIELHUIS, R., Het model belasting en belastbarheid in de sociale geneeskunde.

T1 jdschrift voor soclale geneeskunde $51: 55-59,1973$. 
$-199-$

BIJLAGEN 
$-200-$ 


\section{BIjlage 1}

SAMENSTELLING BEGELEIDINGSCOMMISSIE

H. Riem

Ir. M. Lodewijks

Drs. K. de Jong

Drs. A. Marcet

Ir. J. Coenjaertz

J. Berlott

Drs. P. van Son

Drs. P. Stroink

J. Ernst

Drs. G. Boer

P. Booij jr.

F. van der Smissen

Ir. E. de Tollenaer

Drs. A. Maglelsen

H. Niele

Drs. R. van Amste1
Gedeputeerde Staten van Limburg

(voorzitter tot 1.8 .1982 ),

Gedeputeerde Staten van Limburg

(voorzitter v.a. 1.8.1982),

Provinciale Griffie van Limburg

(secretaris)

Ministerie van Sociale Zaken

Ministerie van Sociale Zaken

Ministerie van Economische Zaken

Ministerle van Volksgezondheid en Milieuhygiëne

Sociale Verzekeringsraad

Federatie van Bedrijfsverenigingen

Bedrijfsgezondheldszorg Z-Limburg

Christelijk National Vakverbond

Industriebond F.N.V.

Limburgse Werkgeversvereniging

Limburgse werkgeversvereniging

N.V. Industriebank LIOF

Stichting C.C.O.Z. 
$-202-$ 


\section{Bijlage 2}

Tabe1 1. De

(bèta's) uit de multiple regressie-analyse van de drie arbeidsongeschiktheidsindicatoren.

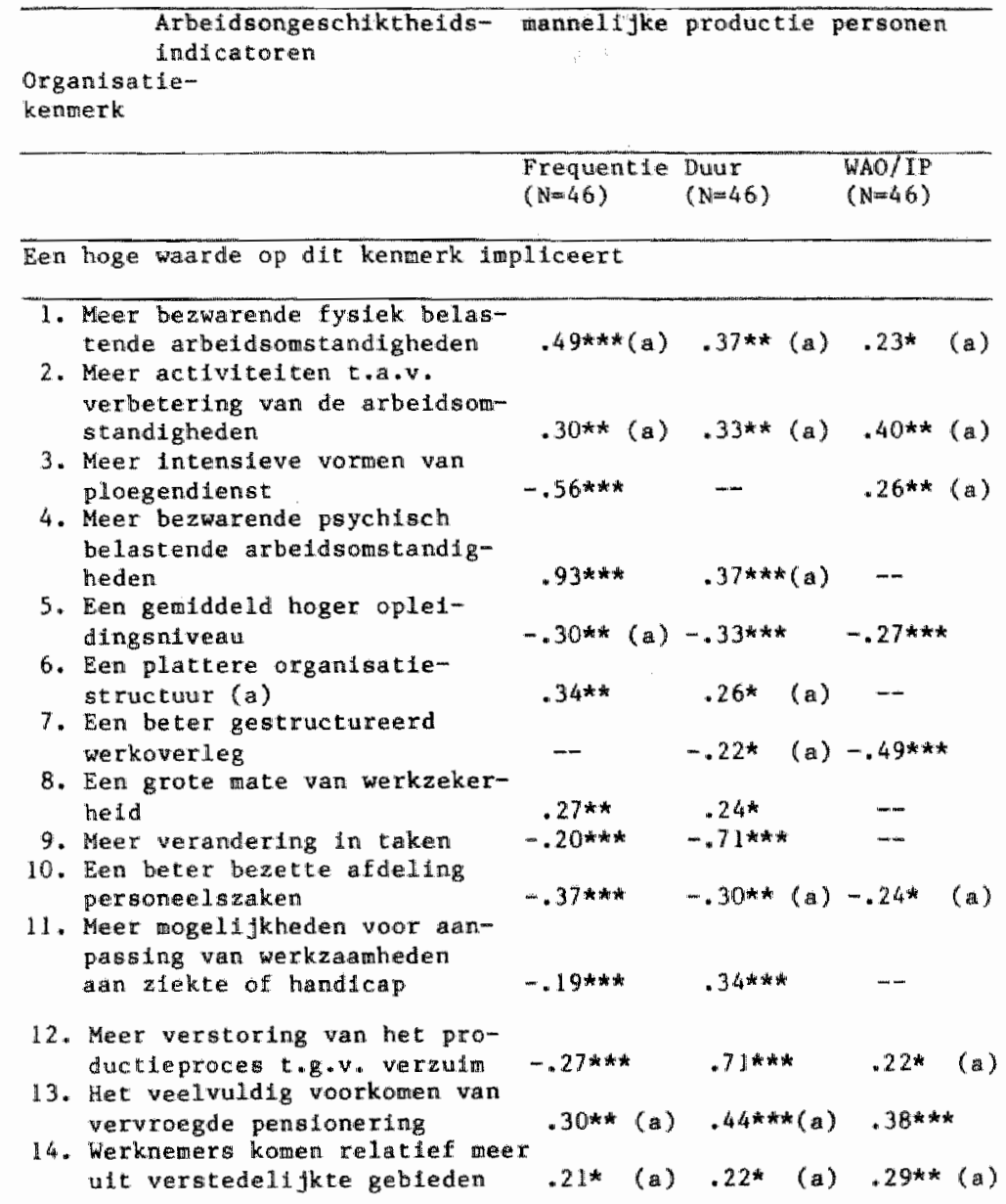

a) 1 plats van (beta): $\mathbf{r}_{\text {, }}$

a1) bij partiallsering niet gepartiallseerd voor zichzelf,

$* * *: \mathrm{p} \leqslant 0.01$

$\star * \quad: 0.01<\mathrm{p} \leqslant 0.05$

* $\quad: 0.05<\mathrm{p} \leqslant 0.10$ 
De in tabel 1 gegeven waarden zijn de (bèta's) uit de multiple regressie-analyse. In de gevallen warin de betreffende organisatievarlabele niet een voldoende significantleniveau in de multiple regressie-analyse behalt, doch wel in de partiële correlatie-analyse dan is deze correlatie weergegeven.

Een negatieve waarde van de of $r$ duldt er op dat een hoge score op de betreffende organisatiekenmerk samenhangt met een geringere verzuimfrequentle, een geringere verzulmduur of met een kleiner aantal toetredingen tot de WAO/IP. 


\section{Bijlage 3}

DE CONSTRUCTIE VAN DE ONAFHANKELIJKE VARIABELEN

Zoals in Nijhuis en Soeters (1982; hoofdstuk 4) beschreven, is in de eerste plaats het totale vragenbestand (ca. 300) op theoretische gronden in groepen ingedeeld.

Over elke groep vragen of items is vervolgens een factor-analyse gedaan (principale factoren met iteraties (Nie et al., 1975). Deze factor-analyse is beperkt tot de ingangsvragen, d.w.z. de doorvragen zijn in deze analyse niet opgenomen.

De items die op de eerste factormatrix een lading hadden kleiner dan . 20 hebben we laten vallen (Brand-Koolen, 1972). Deze items hadden ofwel geen discriminerende warde, ofwel $\mathrm{z}_{1 j}$ hoorden niet bij de door ons geconstrueerde varlabelen. Uitgegaan is van factoren met een elgenwaarde van tenminste 1. Dit alles had tot gevolg dat nu een aantal intern consistente variabelen gevormd werd. Opdat elke varlabele een enkele score per respondent zou krijgen, dienden deze echter nog wel gehercodeerd te worden (in dezelfde richting scoren); bovendien dienden de doorvragen verwerkt te worden. Hoe dit is gedaan, staat telkens in de beschrifving van de variabele in Nijhuls en Soeters (1982, hoofdstuk 4). Omdat hierdoor sommige variabelen wederom veranderden, is de interne consistentle bepaald en wel door middel vn Cronbach's alpha. De waarden van deze is vermeld bif de statistische beschrijving van de variabelen an het elnde van hoofdstuk 4 . Vanaf een alpha-waarde van 0.40 is de betrouwbaarheld van de geconstrueerde varlabele voldoende en vanaf 0.70 goed te noemen (Nunnaly, 1967). Alle aldus geconstrueerde varlabelen in dit onderzoek kunnen op grond hiervan tenminste het predical 'voldoende betrouwbar' toegekend krljgen. 


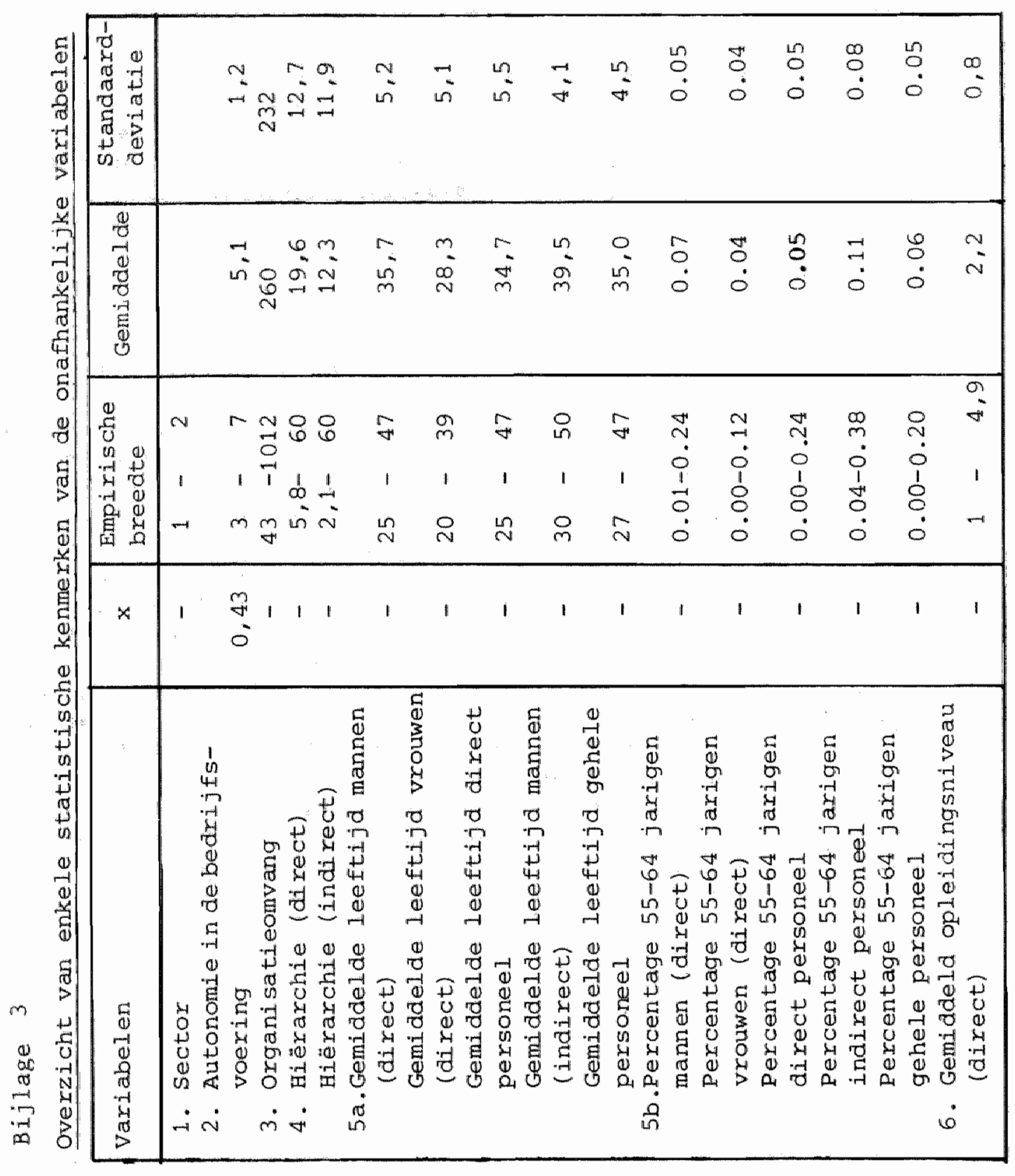




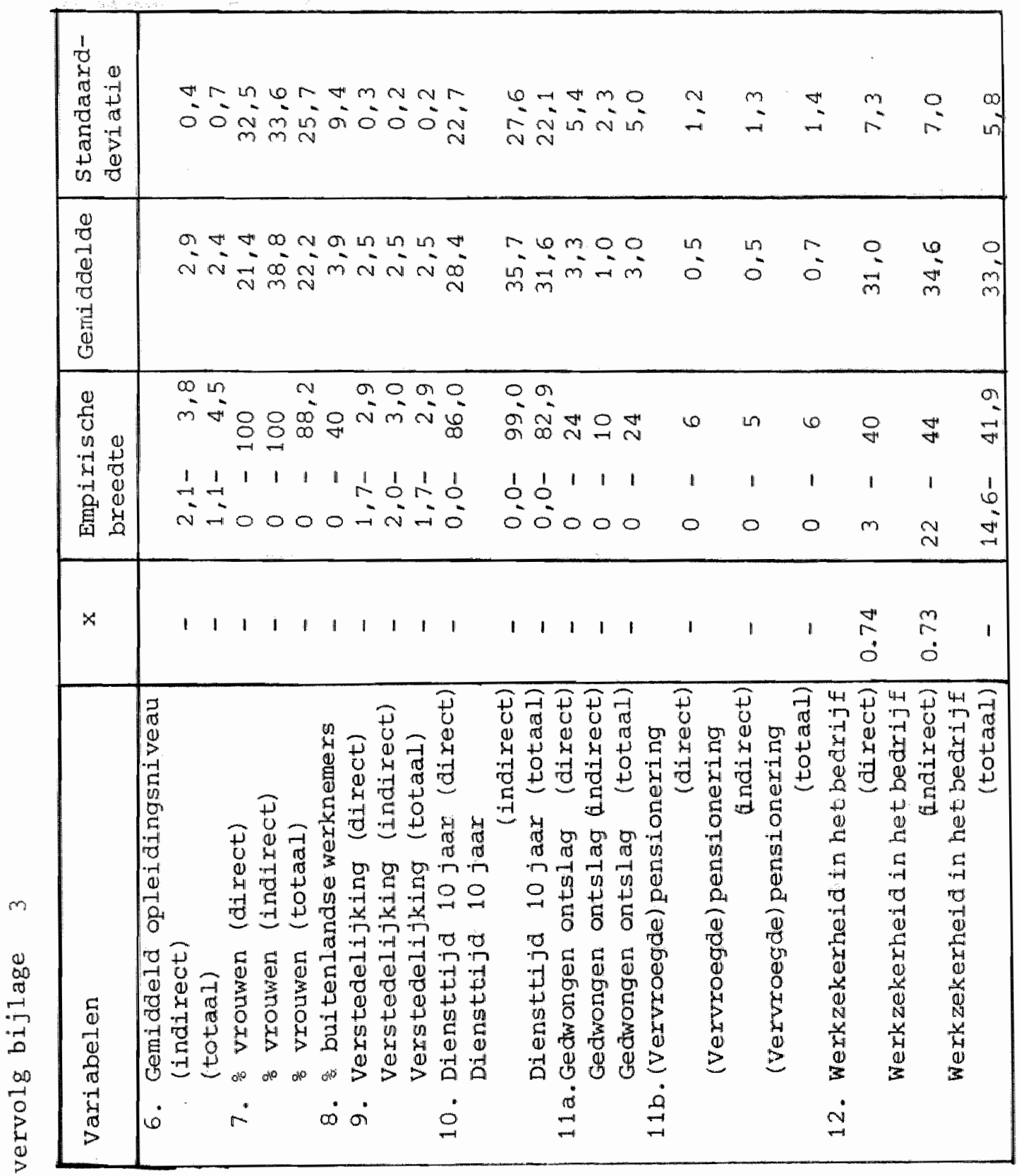




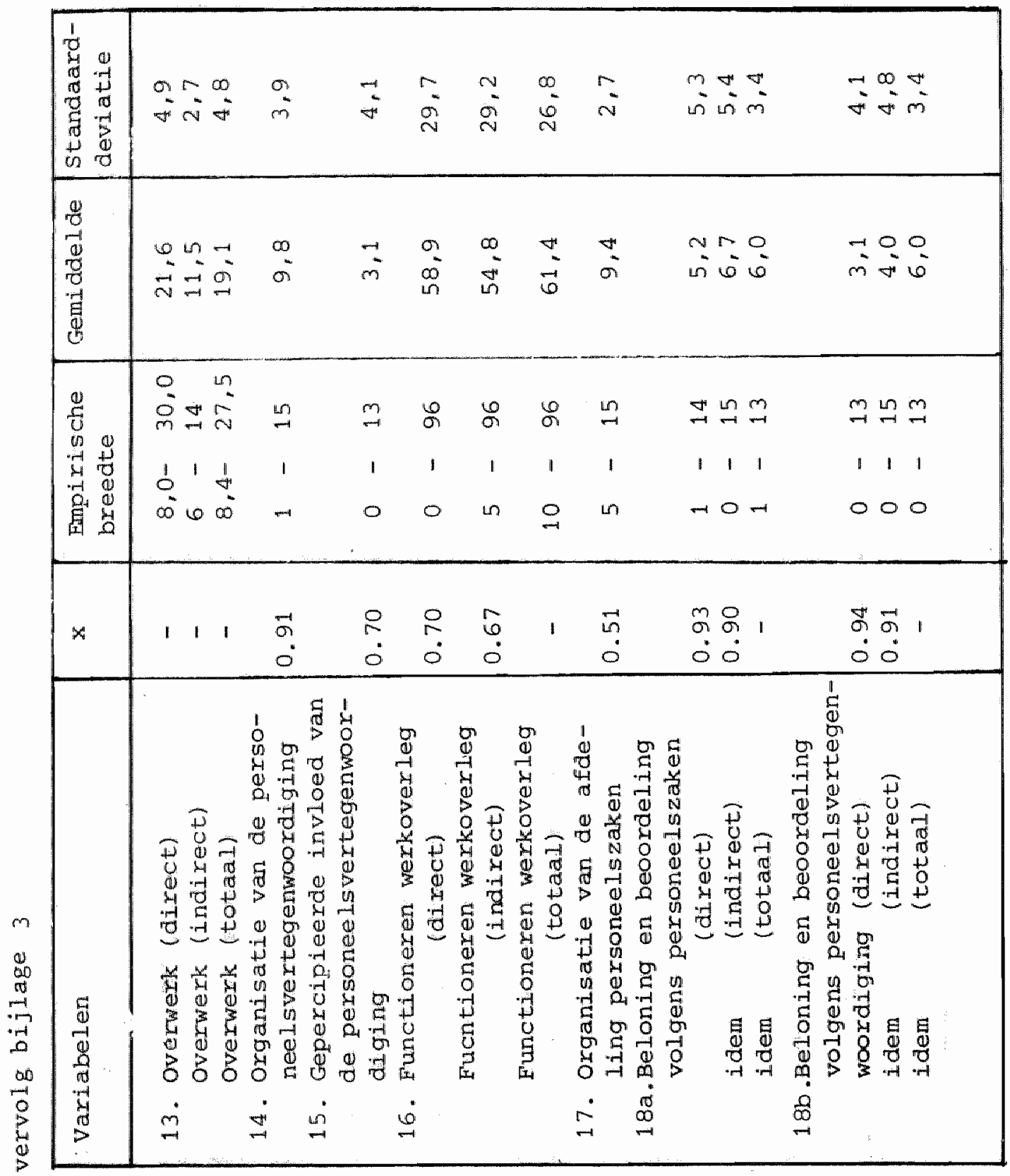




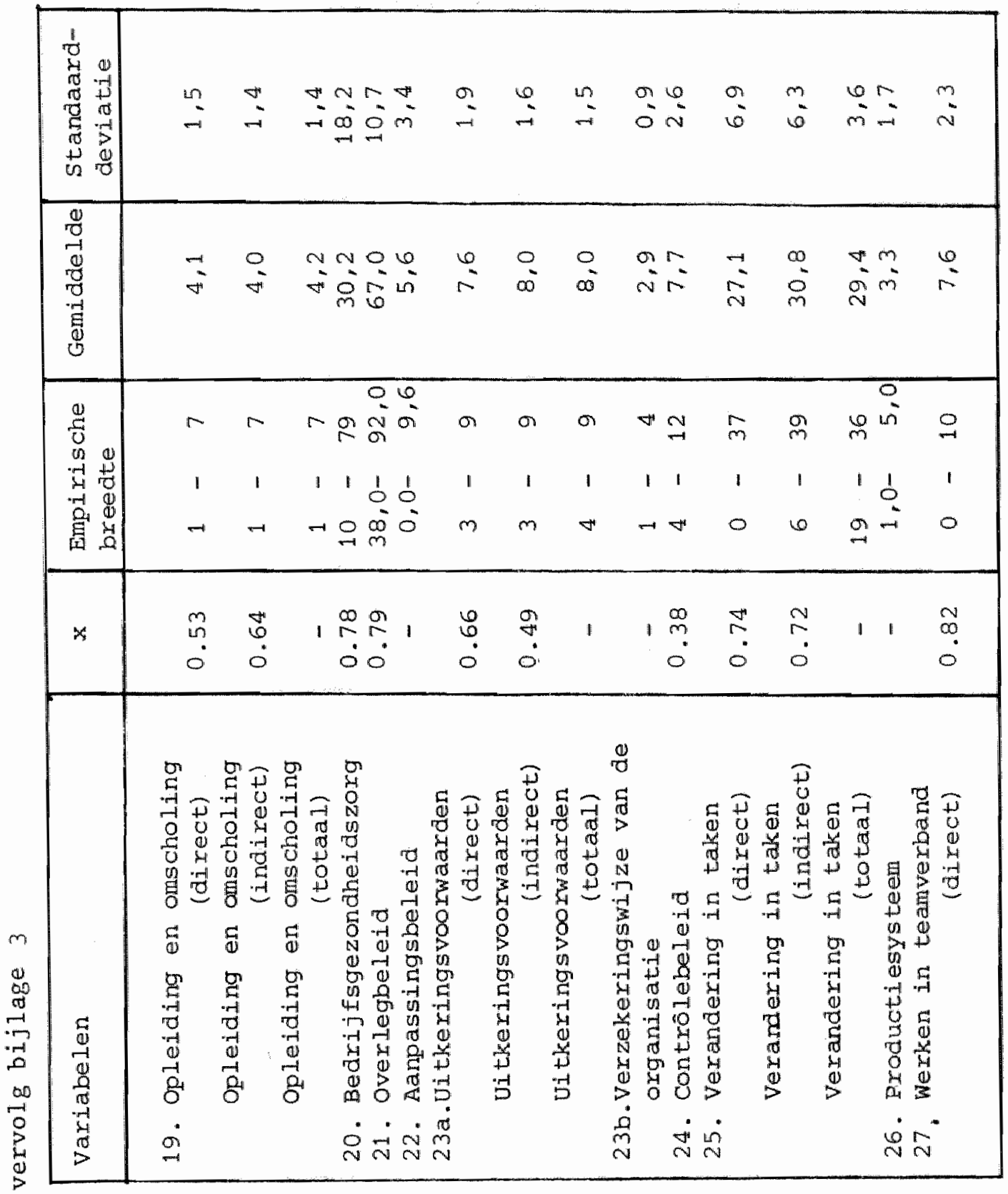




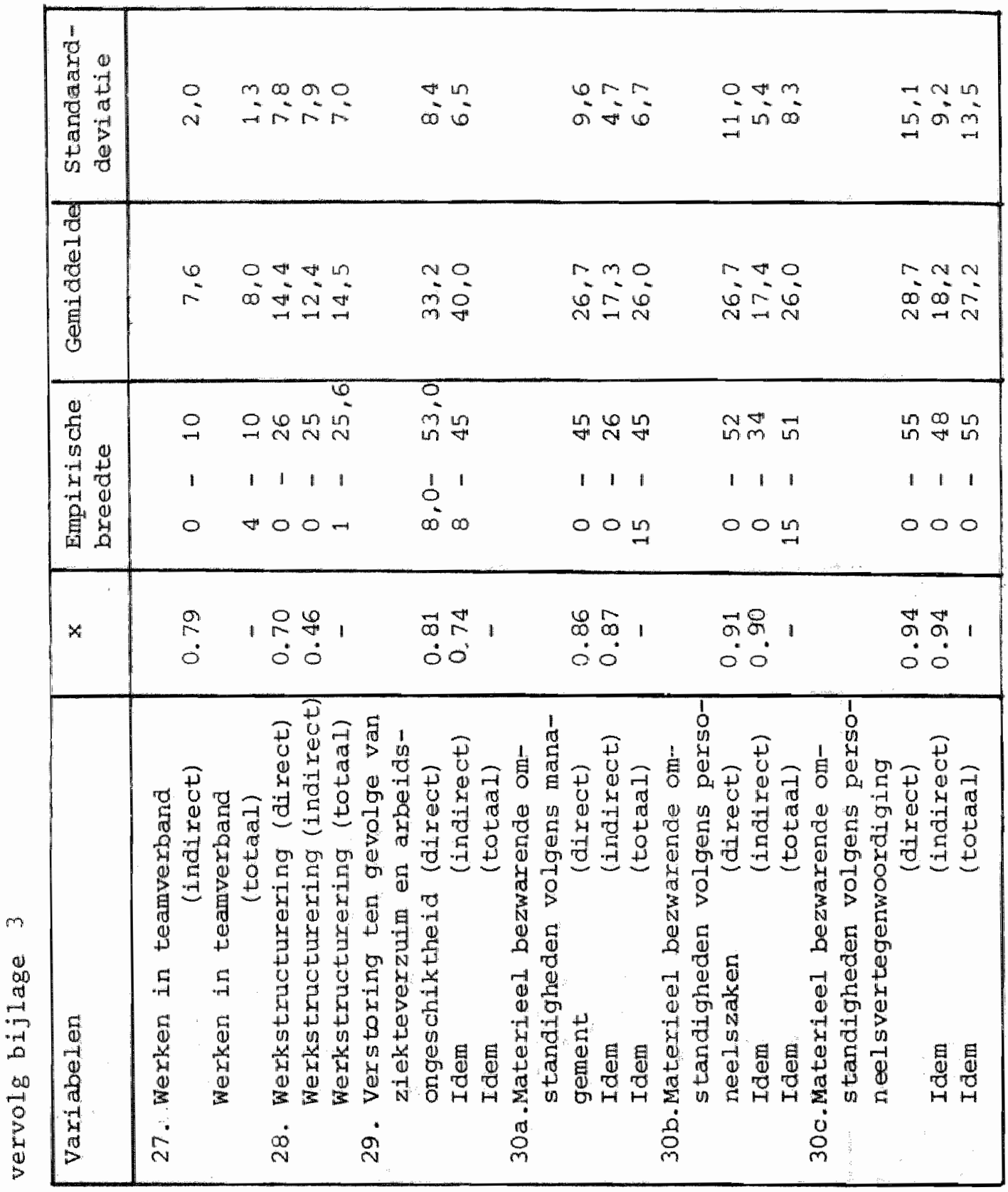




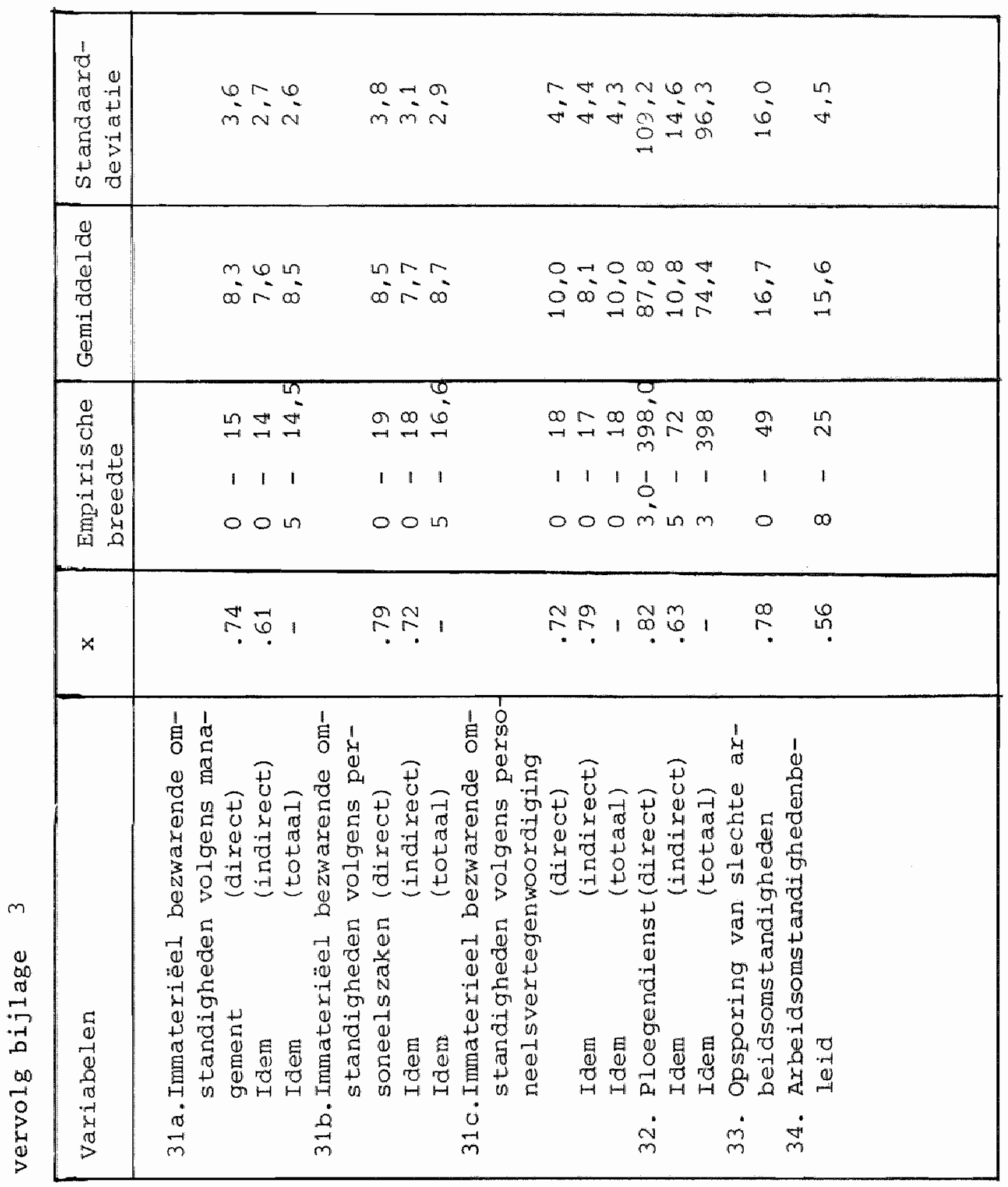




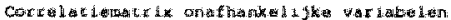

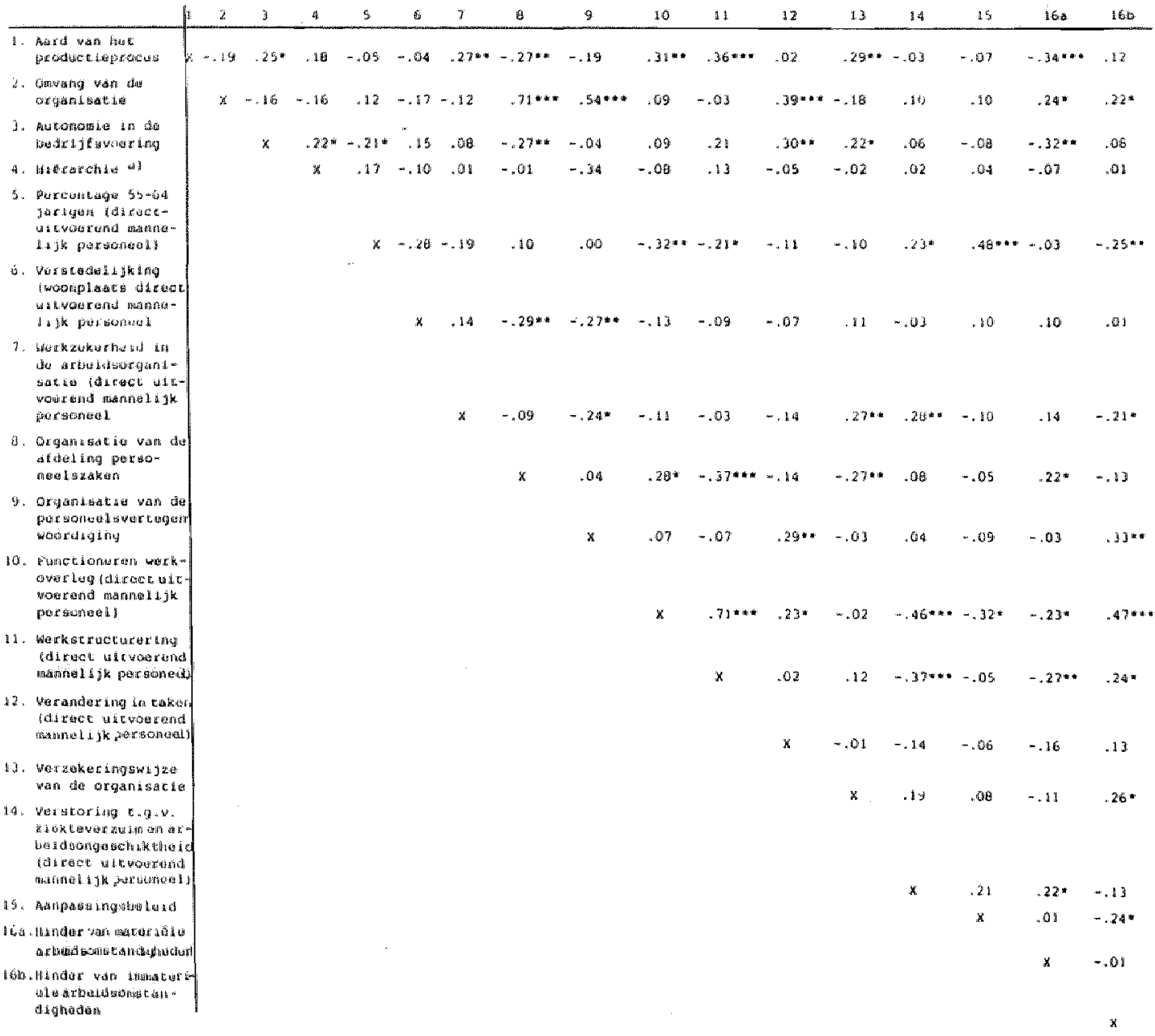

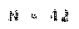

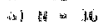

$m * n, 0,0 \mathrm{j}$

* * 而

- $0.050 \mathrm{p} 0.8$ 
Bijlage 5

\begin{tabular}{|c|c|c|c|c|}
\hline Discrepantie-i tens & min - max & gemiddelde & 80 & Womekents \\
\hline 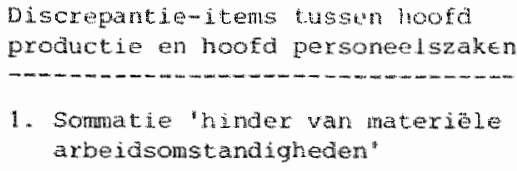 & & & & \\
\hline $\begin{array}{r}\text { management } \\
\text { personealszaken }\end{array}$ & $\begin{array}{l}16.0-48.0 \\
17.0-55.0\end{array}$ & $\begin{array}{l}30.9 \\
30.9\end{array}$ & $\begin{array}{l}7.7 \\
9.6\end{array}$ & $\begin{array}{l}\text { loog } 19 \text { weet. } \\
\text { hindex }\end{array}$ \\
\hline $\begin{array}{l}\text { 2. Sommatie 'hinder van Immate- } \\
\text { riele arbeidsomstandigheden' } \\
\text { marsonemagenent } \\
\text { puaken }\end{array}$ & $\begin{array}{l}5.0-15.0 \\
5.0-19.0\end{array}$ & $\begin{array}{l}9.0 \\
9.7\end{array}$ & $\begin{array}{l}3.0 \\
3.4\end{array}$ & $\begin{array}{l}\text { hoog is ved } \\
\text { hinder }\end{array}$ \\
\hline 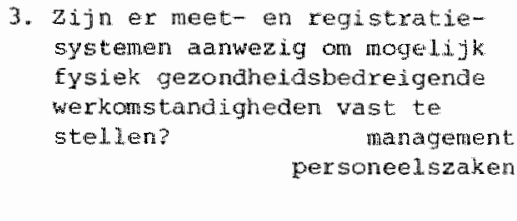 & $\begin{array}{l}1.0-3.0 \\
1.0-3.0\end{array}$ & $\begin{array}{l}2.2 \\
2.2\end{array}$ & $\begin{array}{l}1.0 \\
1.0\end{array}$ & $\begin{array}{l}1=j a \\
2=b \operatorname{seckt} \\
y=\text { nee }\end{array}$ \\
\hline $\begin{array}{l}\text { Discrepantie tussen hoofd produc- } \\
\text { tie en de personeelswertegenwoor } \\
\text { diging } \\
\text { 1. Somatie "hirder van meteriele } \\
\text { arbeidsomstancigheden" }\end{array}$ & & & & \\
\hline $\begin{array}{r}\text { management } \\
\text { personee svertegenwoordiging }\end{array}$ & $\begin{array}{l}16.0-48.0 \\
16.0-58.0\end{array}$ & $\begin{array}{l}30.9 \\
36.7\end{array}$ & $\begin{array}{r}7.7 \\
11.1\end{array}$ & $\begin{array}{l}\text { hoogis verel } \\
\text { hinder }\end{array}$ \\
\hline $\begin{array}{l}\text { 2. Sommatie "hinder van imatem } \\
\text { ciele abeidsomstamigheden" } \\
\text { management } \\
\text { persomerlsvertegerwoordiging }\end{array}$ & $\begin{array}{l}5.0-1.5 .0 \\
5.0-19.0\end{array}$ & $\begin{array}{r}9.0 \\
10.6\end{array}$ & $\begin{array}{l}3.0 \\
3.8\end{array}$ & 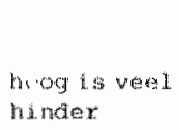 \\
\hline 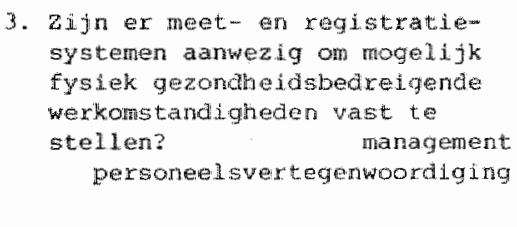 & $\begin{array}{l}1.0-3.0 \\
1.0 \mathrm{~m} 3.0\end{array}$ & $\begin{array}{l}2.3 \\
2.1\end{array}$ & $\begin{array}{l}0.9 \\
0.9\end{array}$ & $\begin{array}{l}1=t a \\
2=1 \mathrm{perkt} \\
3=\operatorname{meg}\end{array}$ \\
\hline 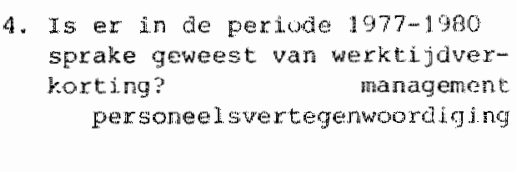 & $\begin{array}{l}1.0-3.0 \\
1.0-3.0\end{array}$ & $\begin{array}{l}2.9 \\
2.9\end{array}$ & $\begin{array}{l}0.4 \\
0.7\end{array}$ & $\begin{array}{l}1=j a \\
2=\text { beperkt } \\
\text { I nee }\end{array}$ \\
\hline 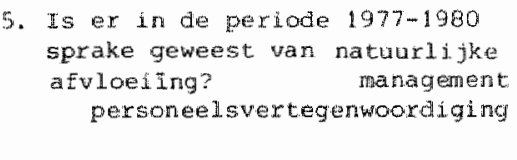 & $\begin{array}{l}1.0-3.0 \\
1.0-3.0\end{array}$ & $\begin{array}{l}2.3 \\
2.2\end{array}$ & $\begin{array}{l}1.0 \\
1.0\end{array}$ & $\begin{array}{l}1=y \text { al } \\
2=\text { beperkt } \\
3 \text { wise }\end{array}$ \\
\hline
\end{tabular}


vervoly bijlaye 5

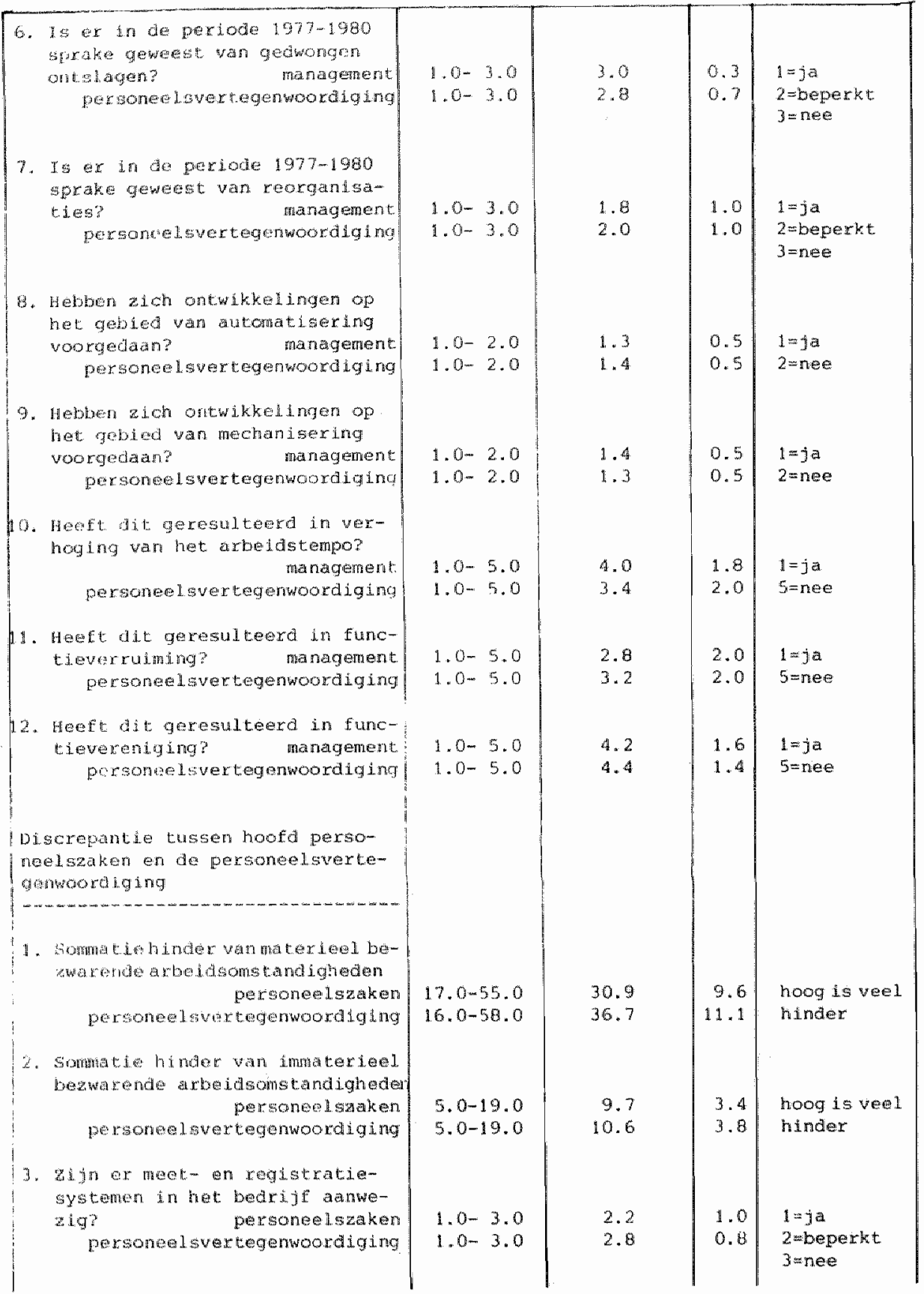


vervolg bijlage 5

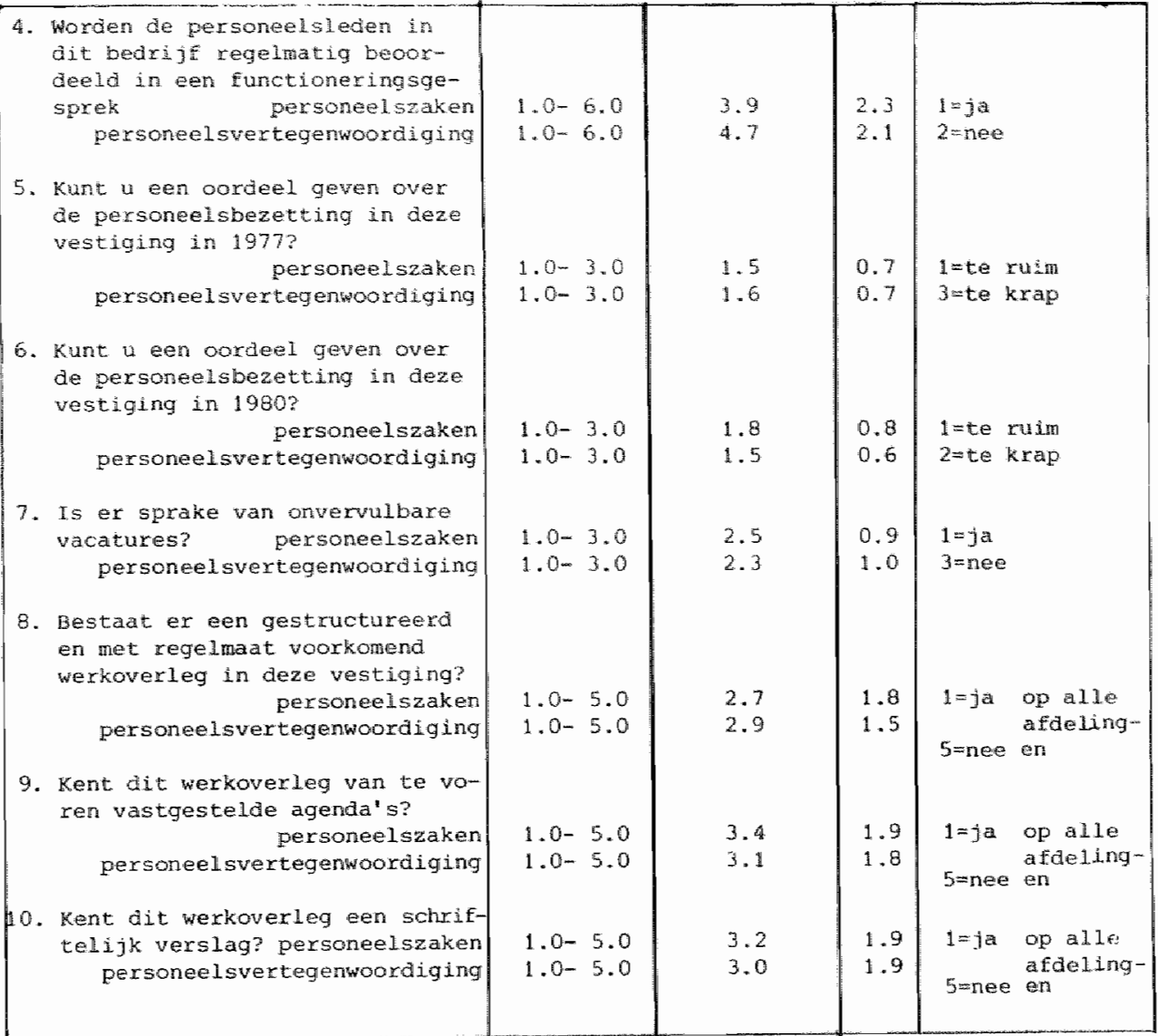


Bijlage 6: Matrices behorende bij tabe1 6.6. 


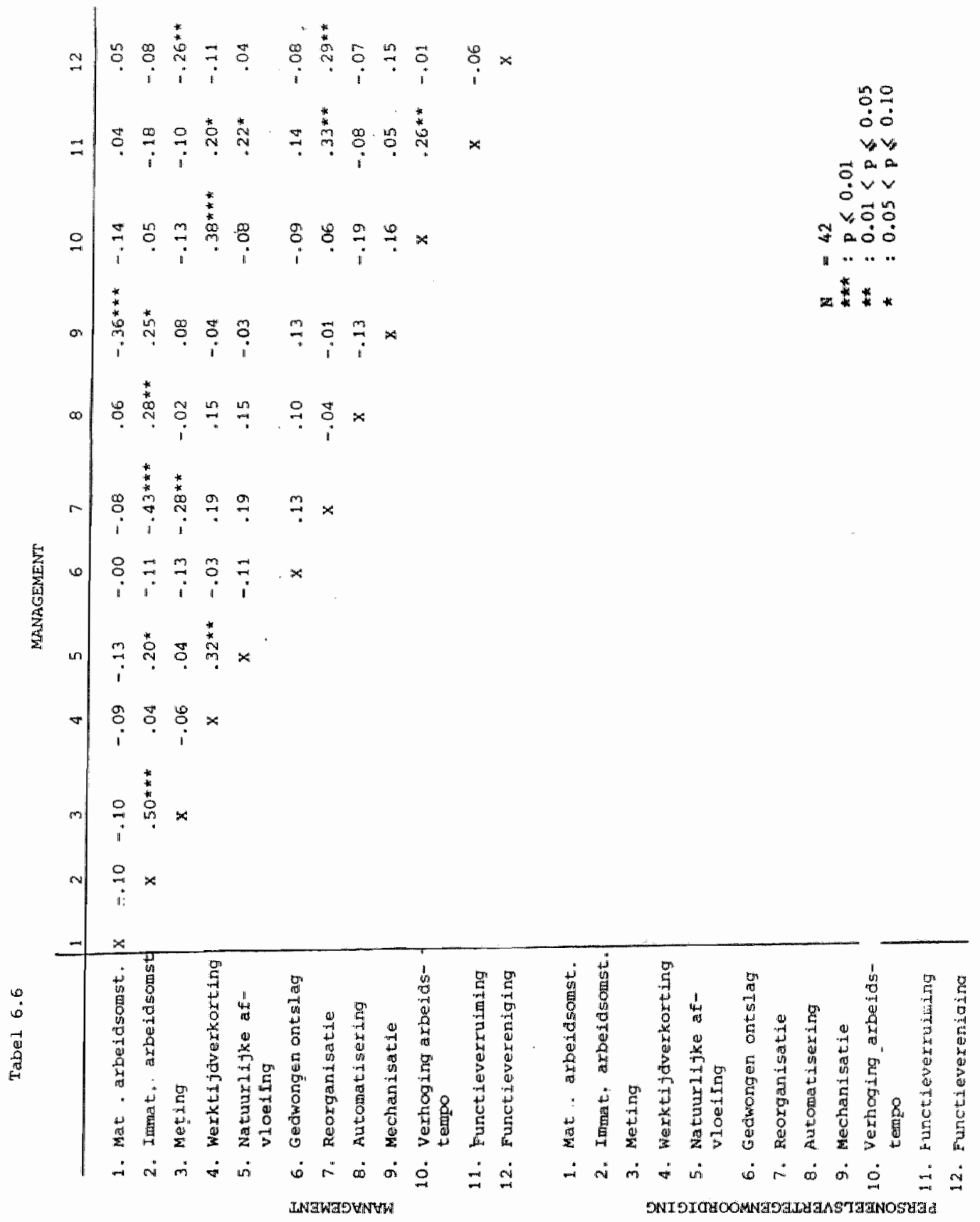




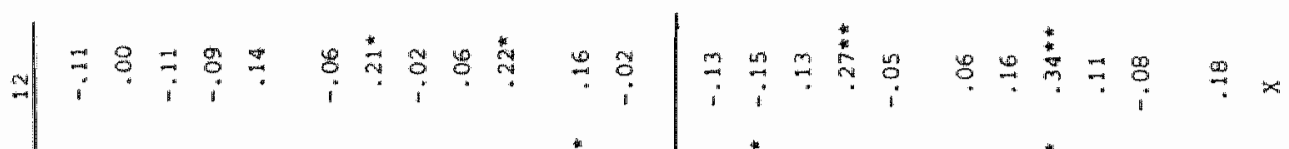

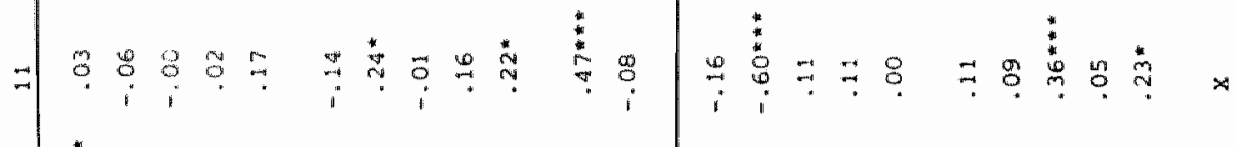

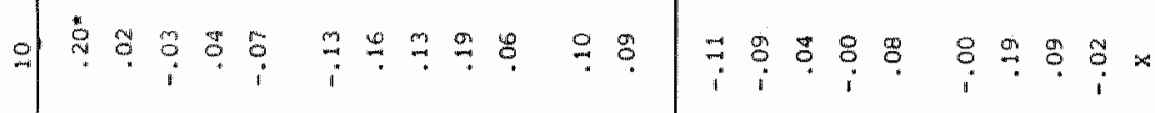

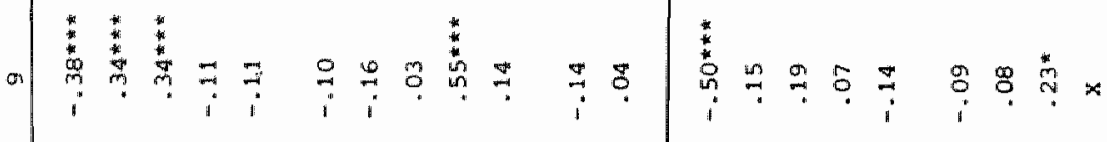

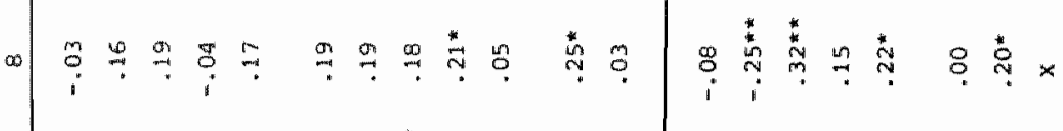

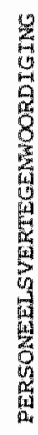

$\infty$

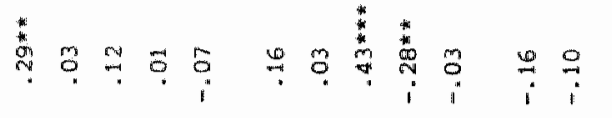

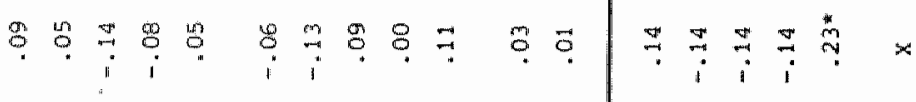

n

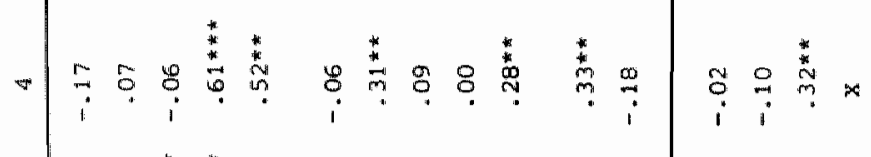

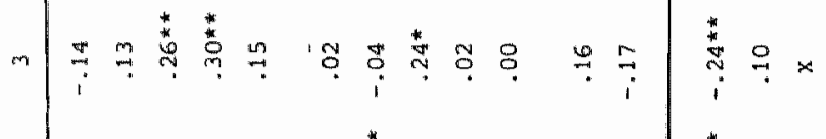

N

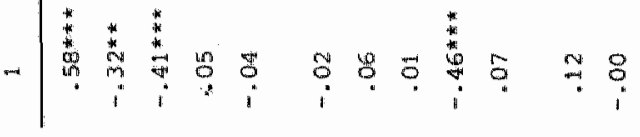

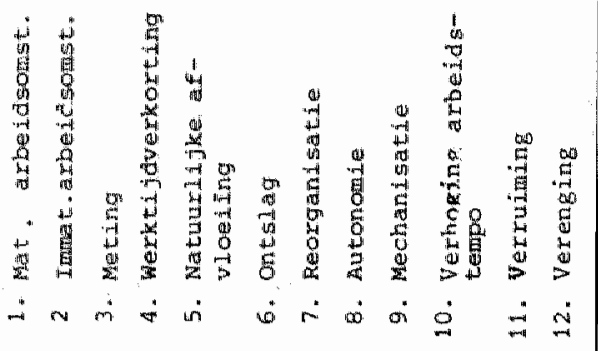

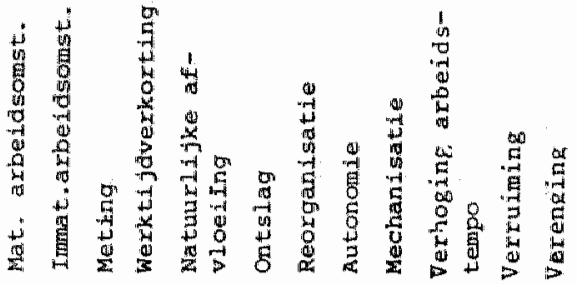

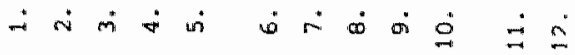


Bijlage 7: Matrices behorende bij tabe1 6.7 . 


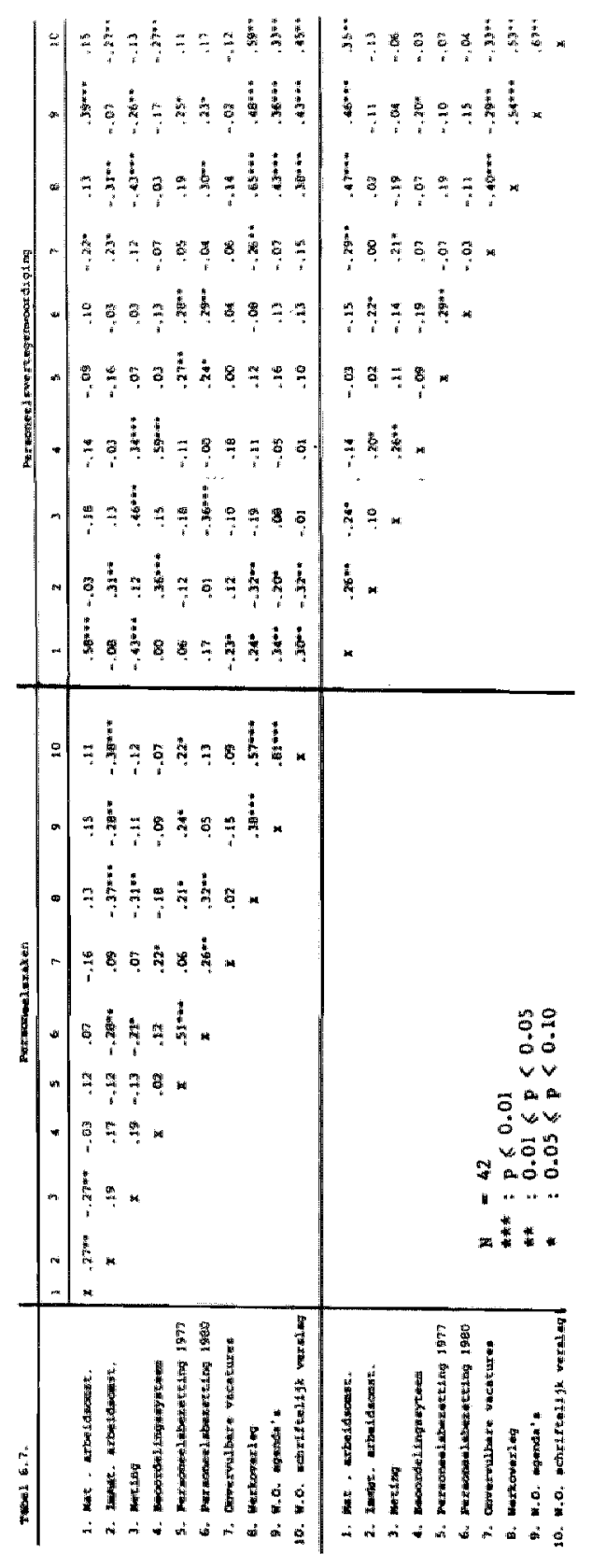




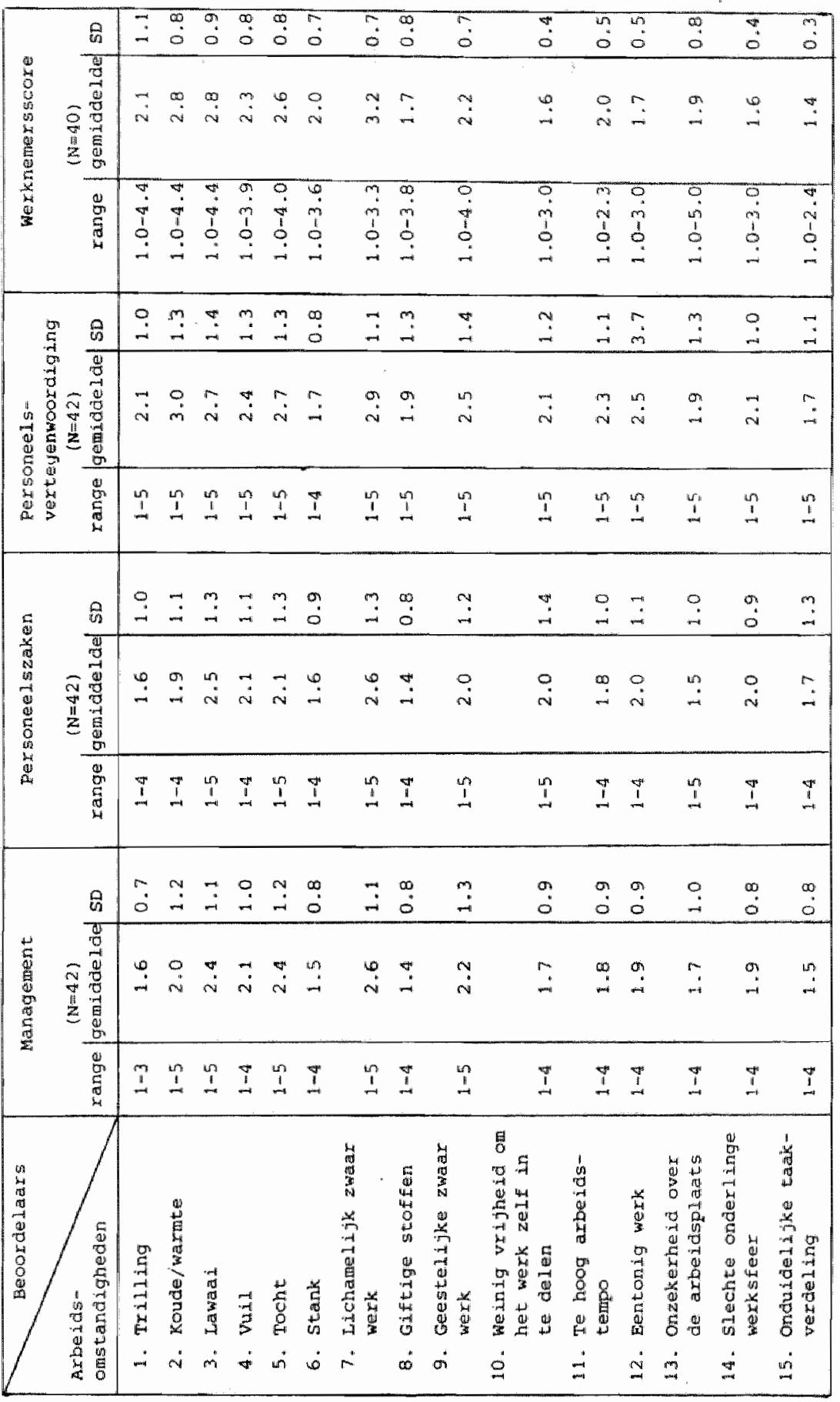


Bijlage 9: Correlatie Matrices behorende bij hoofdstuk 7 . 


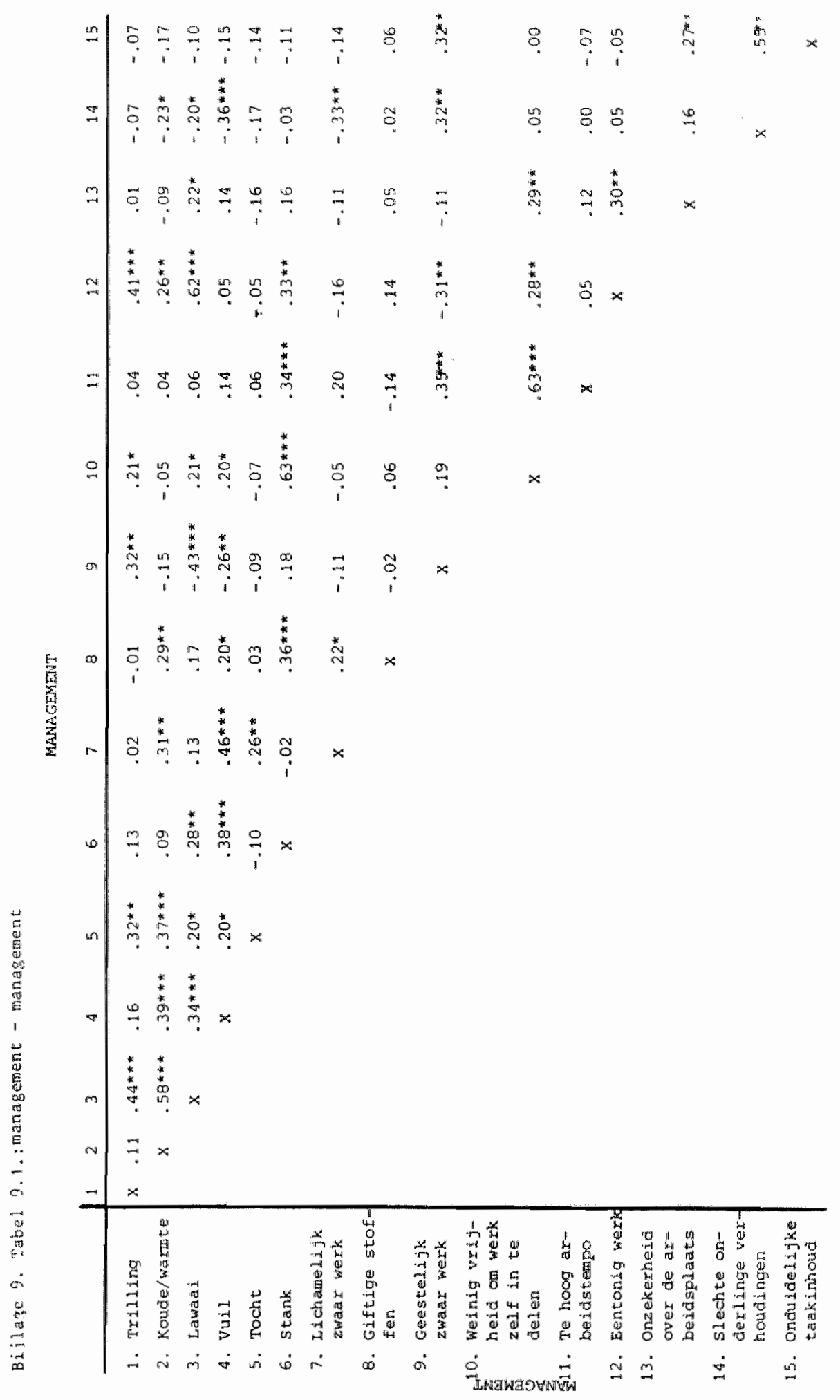




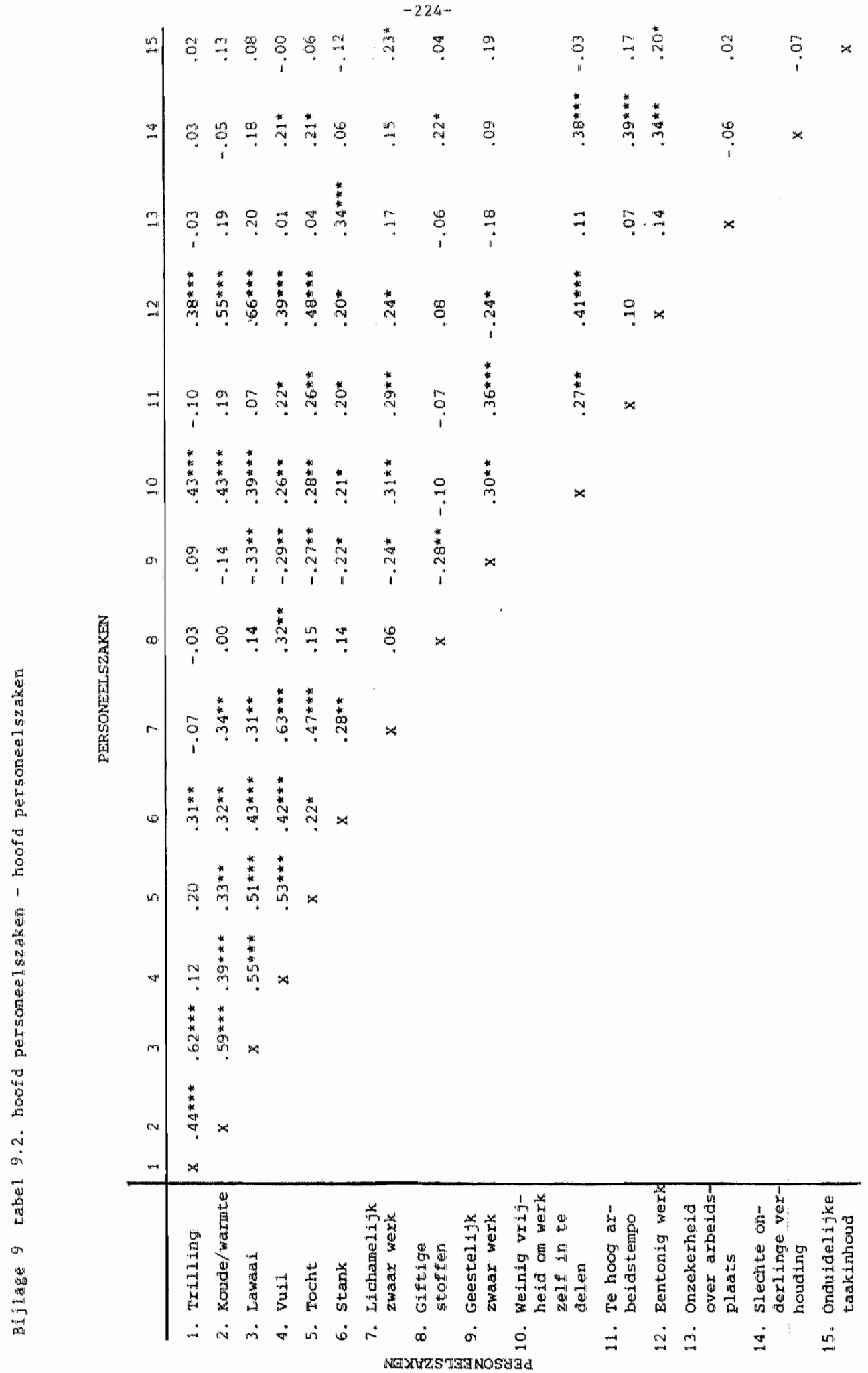




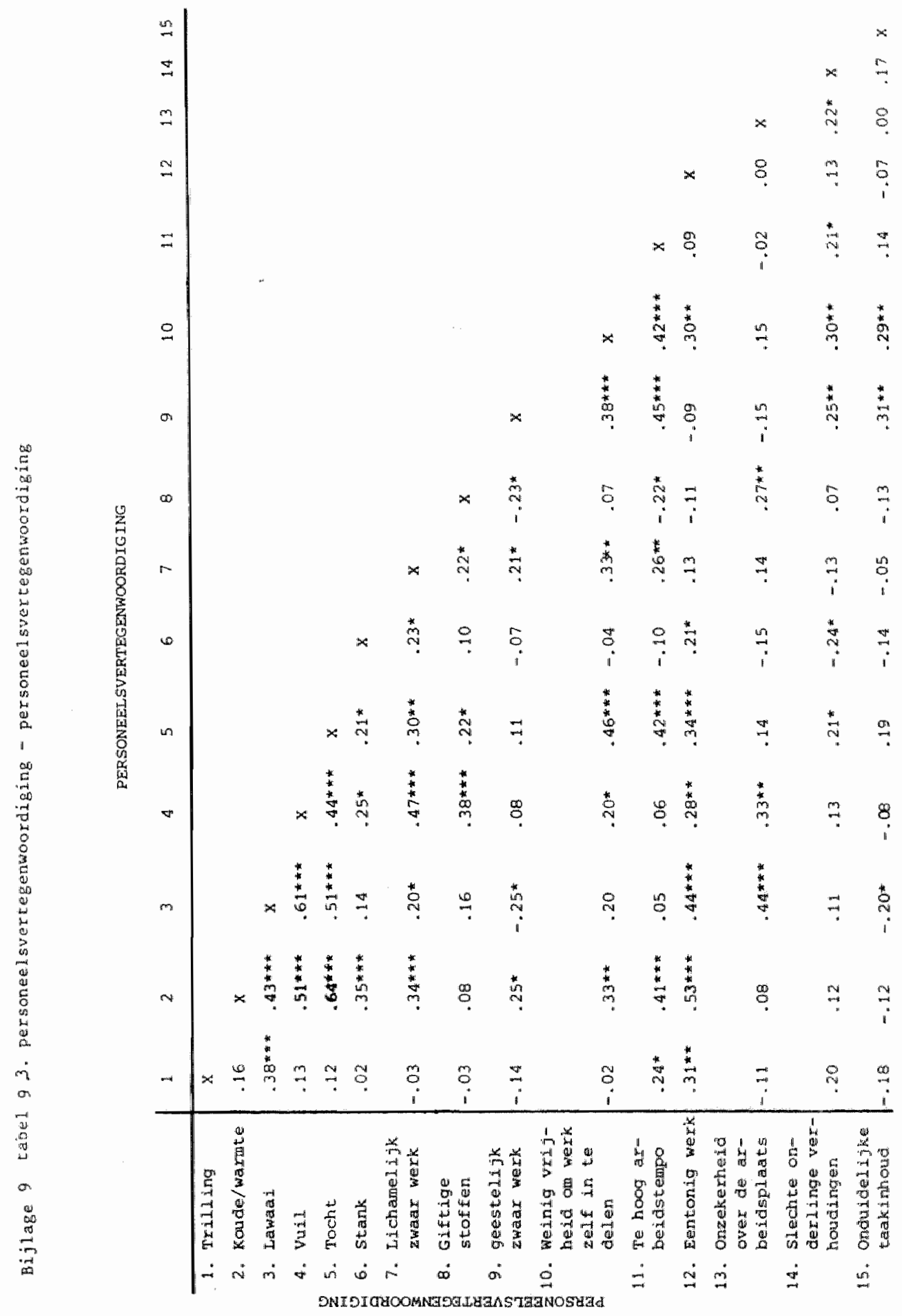




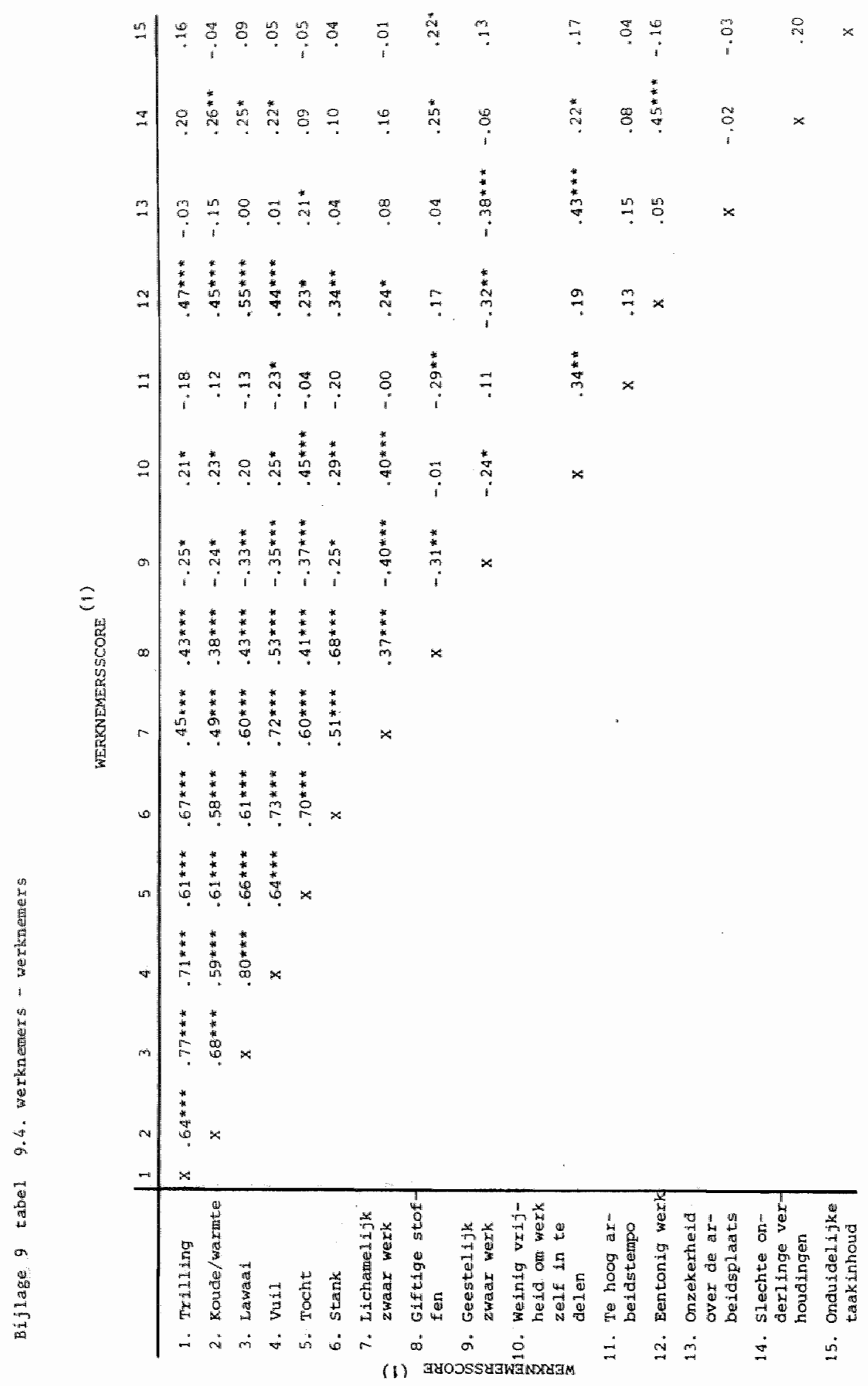




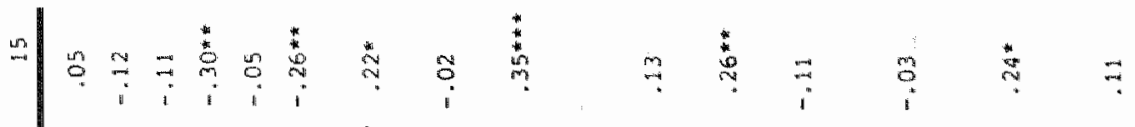

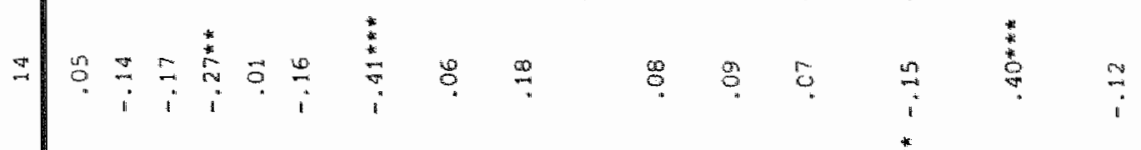

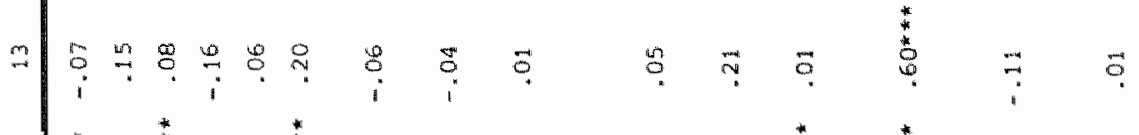

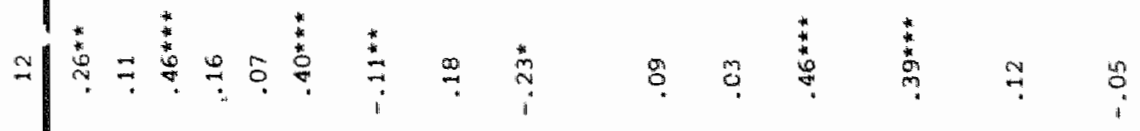

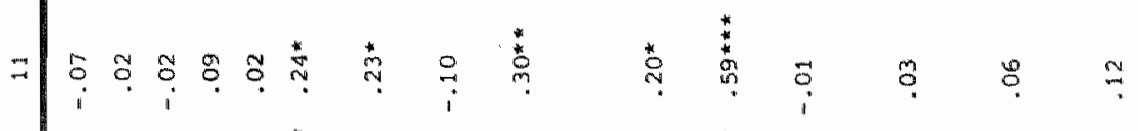

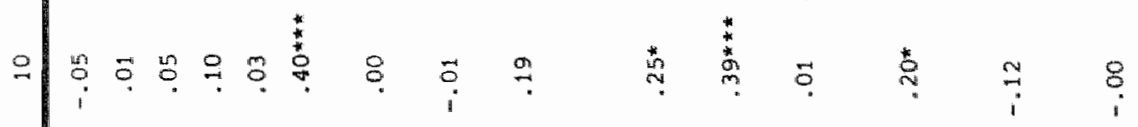

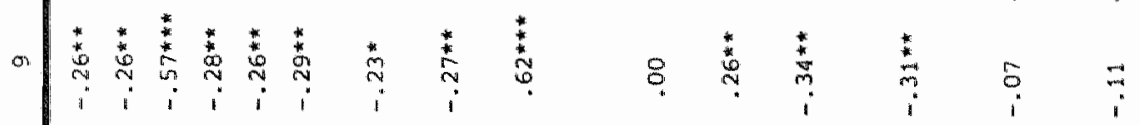

-

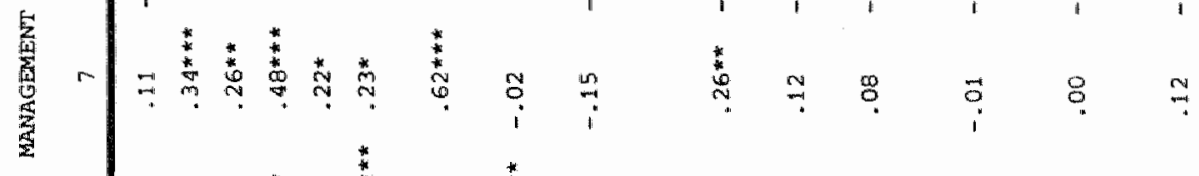

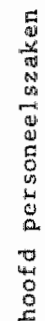

-

-

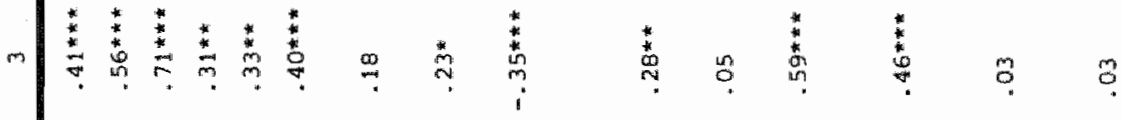

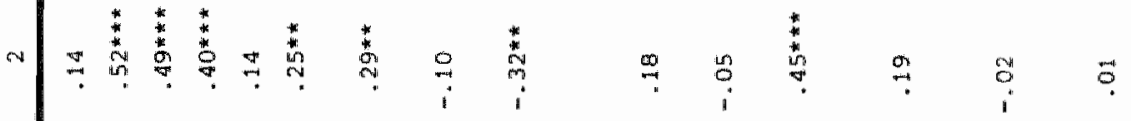

\%

索

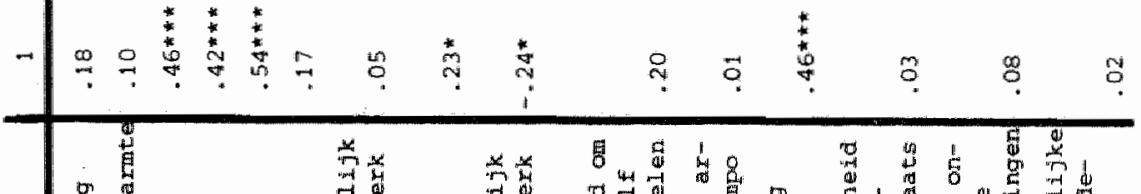

in

$\stackrel{\circ}{\rightarrow}$

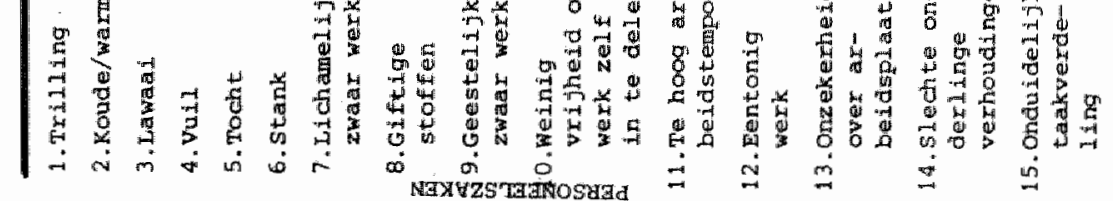




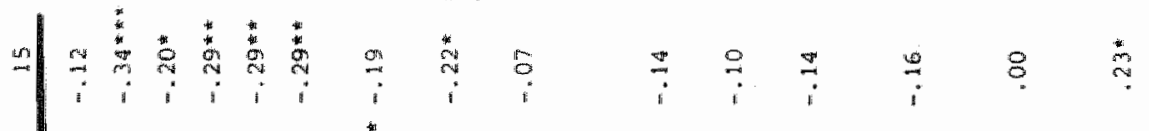

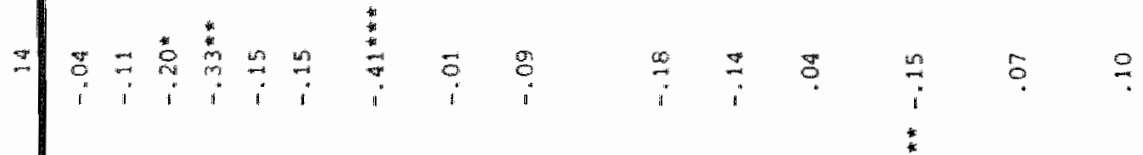

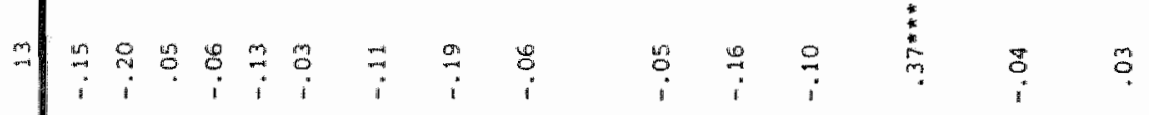

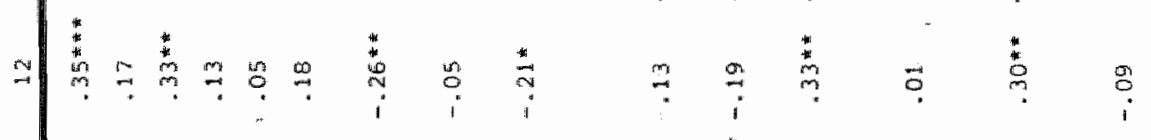

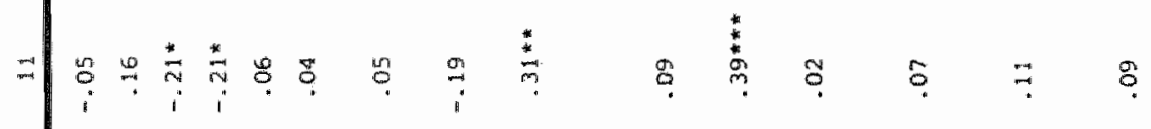

ำ

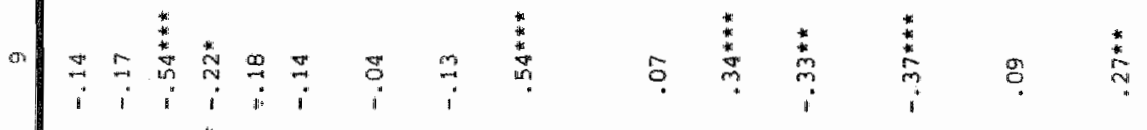

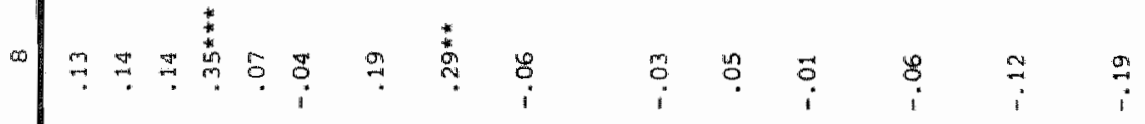

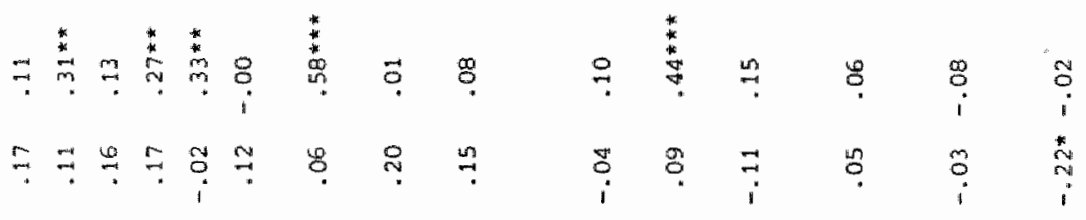

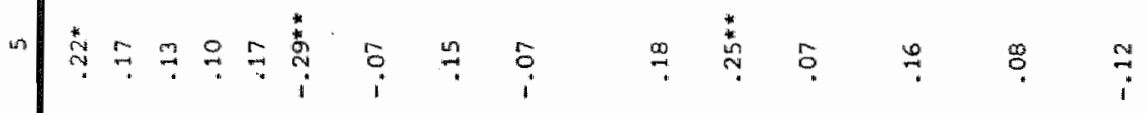

-

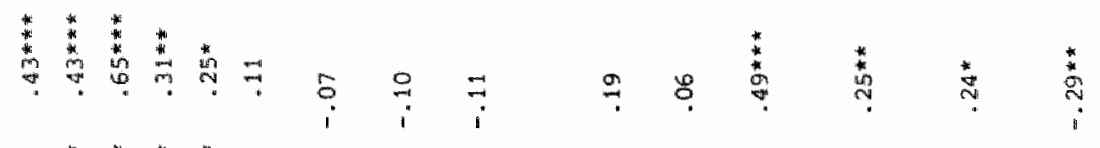

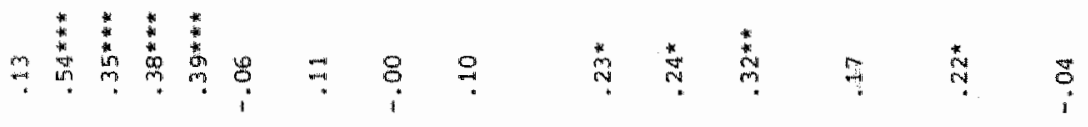

$\frac{1}{4}$

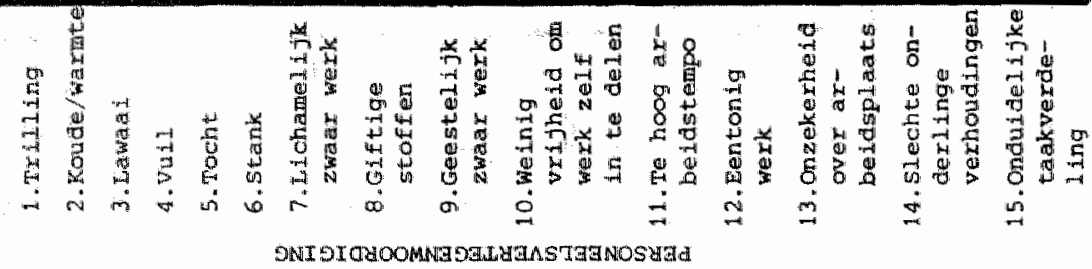




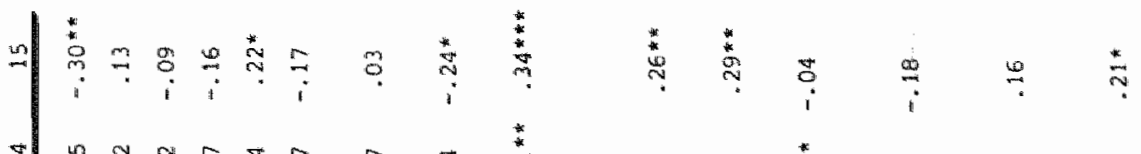

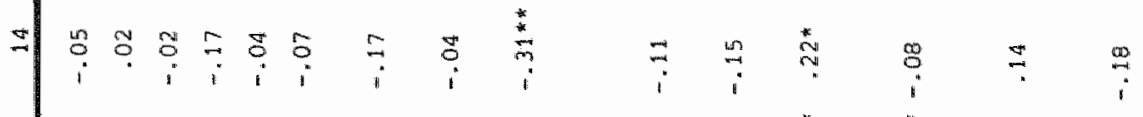

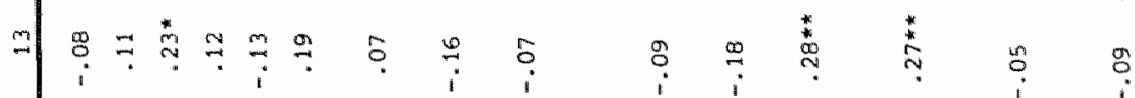

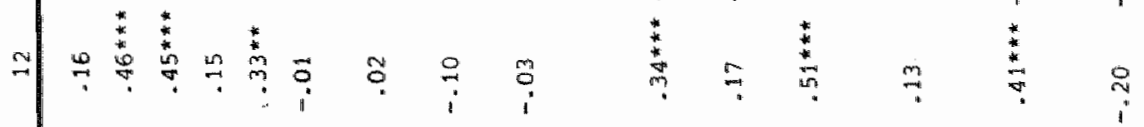

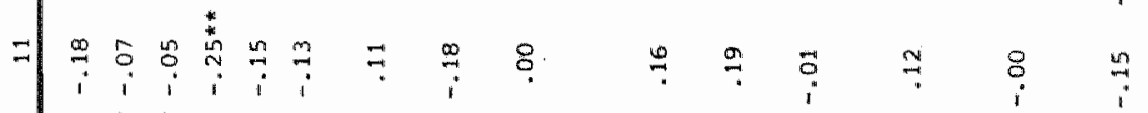

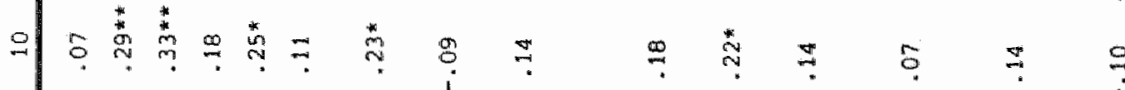

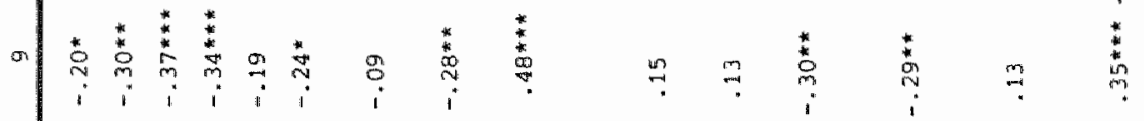

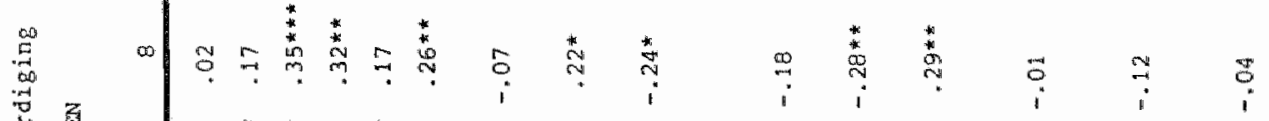

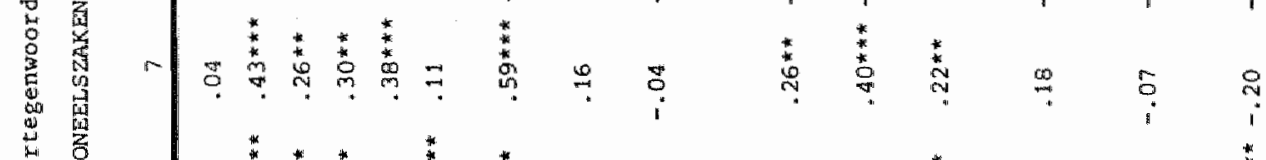

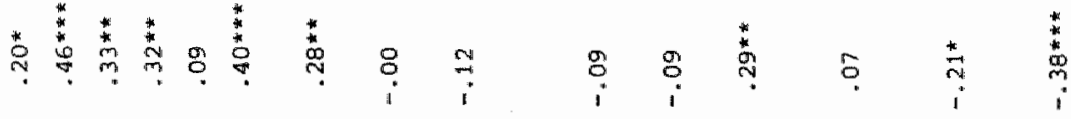

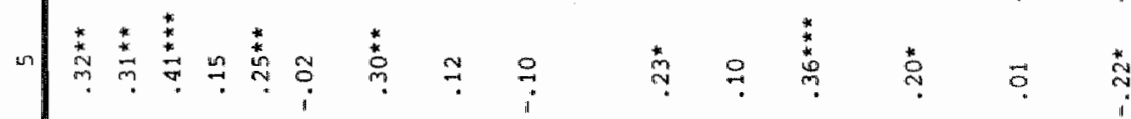

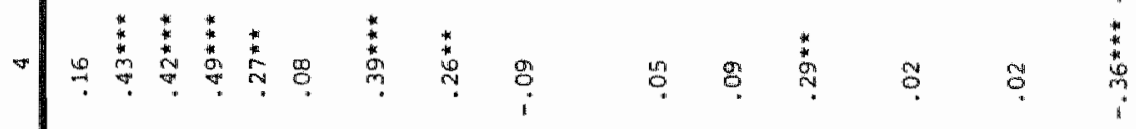

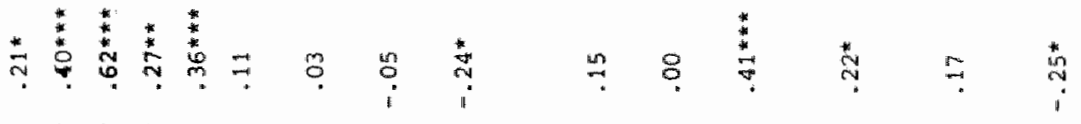

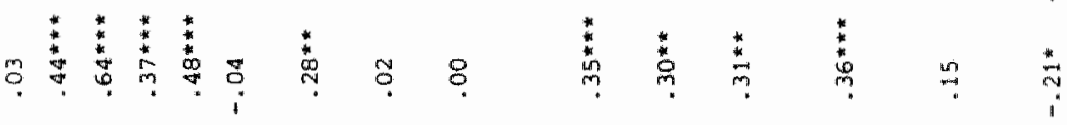

?.

ä

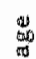

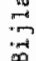

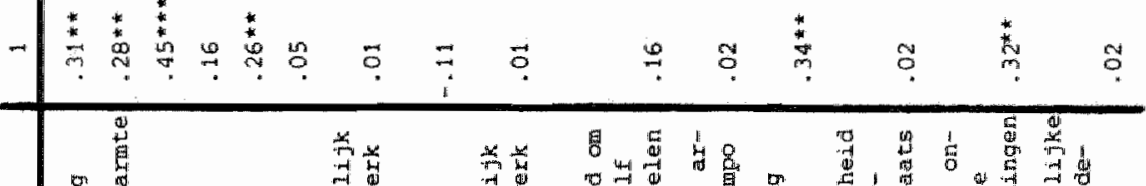

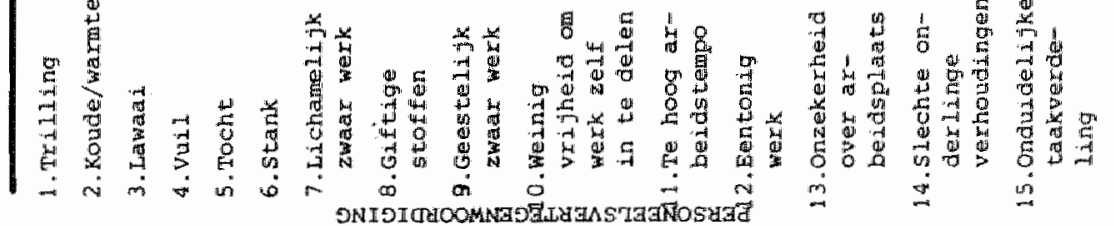




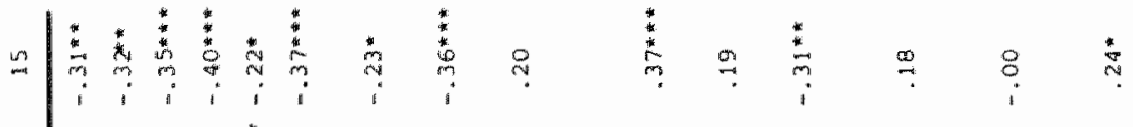

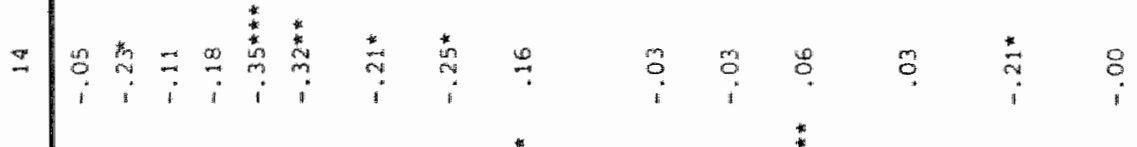

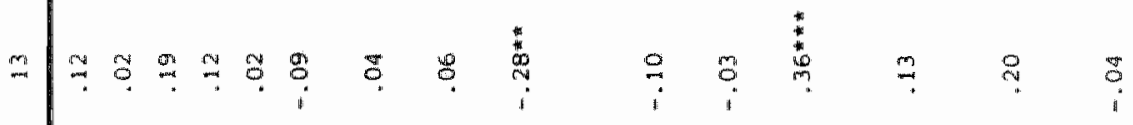

$\left.\simeq\right|_{m} ^{*}$

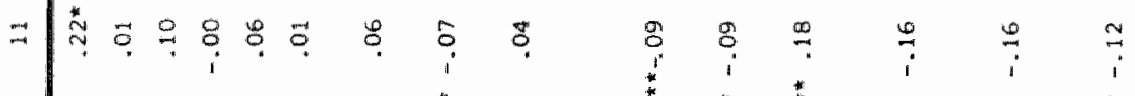

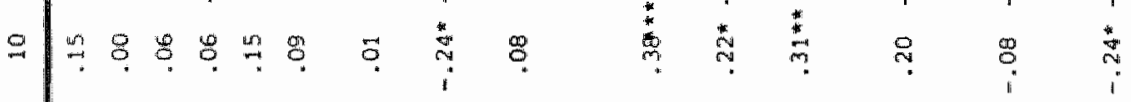

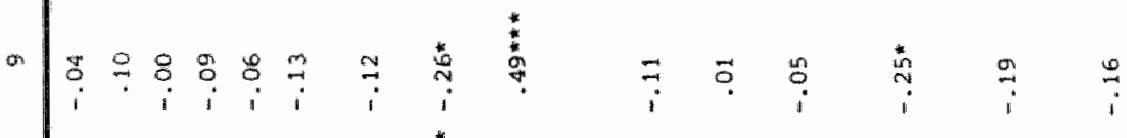

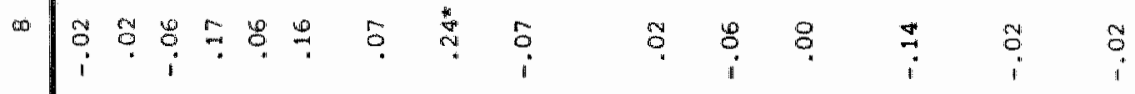

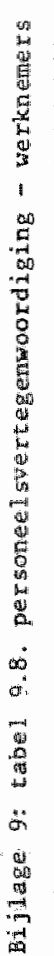

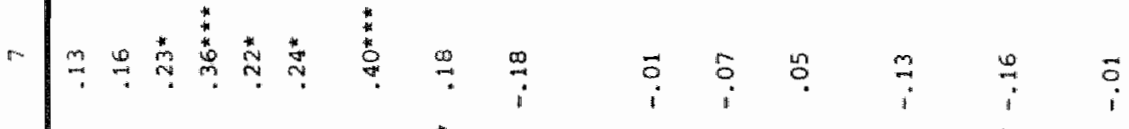

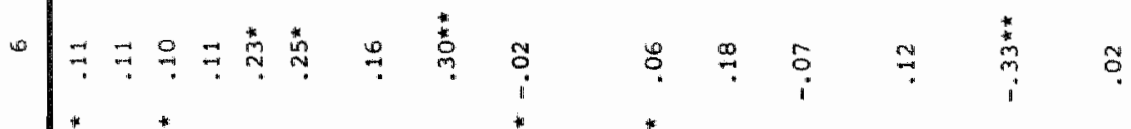

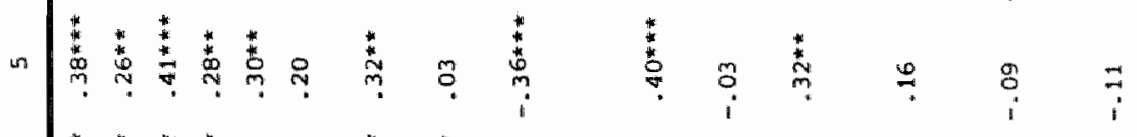

ง

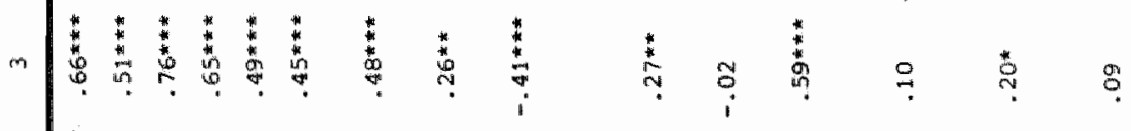

N

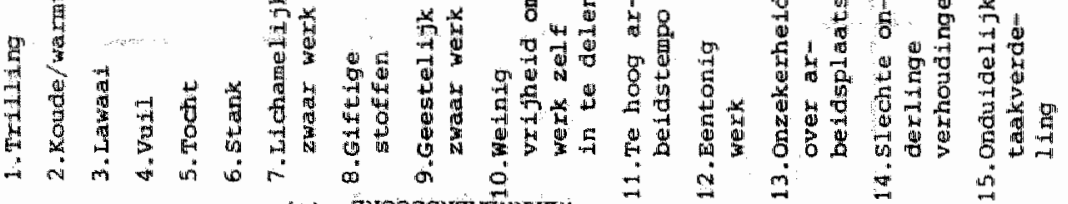

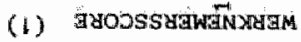


$N=42$

1) $\mathrm{N}=40$

$* * * \quad p \leqslant 0.01$

$* * \quad 0.01<\mathrm{p} \leqslant 0.05$

* $\quad 0.05<p \leqslant 0.10$ 
$-232-$ 
Nawoord

Velen hebben een bijdrage geleverd aan de totstandkoming van dit proefschrift. Hen allen ben ik veel dank verschuldigd. slechts enkelen wil ik hier afzonderlijk benoemen.

Allereerst mijn promotores: Prof.Dr. J.J.C.B. Bremer en Prof.Dr. H. Philipsen, die beïde op hun eigen wijze een belangrijke steun in de rug zijn geweest. Prof. Bremer die de voortgang bewakkte en zeer nauwgezet eerdere versies van commentaar voorzag en Prof. Philipsen, die als begeleider van het Zuld-Limburgse ziekteverzuimproject, voldoende vrijheid gaf om daarbinnen een eigen weg te bewandelen.

Voorts de referenten voor de manier waarop zij dit proefschrift beoordeelden. Prof.Dr. Ch. de Wolff voor zijn kritische vragen ten aanzien van enkele aspecten waar $1 \mathrm{k}$ lichtvoetig over heen gelopen was en Prof.Dr. Tj. de Boorder die een aantal onvolkomendheden in het manuscript wist aan te duiden.

Het Zuid-Limburgse ziekteverzuimonderzoek is uitgevoerd in samenwerking met $J$. Soeters en $C$. Schröer. De samenwerking in dit project is altijd zeer positief en stimulerend geweest.

Veel van het uitvoerende werk is ook op andere schouders dan de mijne terecht gekomen. Zo is het veldwerk mede uitgevoerd door P. Wolf en J. Soeters. Een groot deel van de statistische verwerking is op snelle en doeltreffende wijze uitgevoerd door J. van Houtem.

Van de eerste tot de laatste letter is de administratieve verwerking in handen geweest van A. Silanoe-Verweij, die telkens weer mijn aantekeningen en wijzigingen zeer precies verwerkte. Zij werd in het werk aan de soms omvangrijke tabellen bijgestaan door I. van Noppen.

Voorts wil ik A. Landeweerd, J. Spangenberg, T. N1jhuis en Th. Rieff bedanken voor hun commentaar op eerdere teksten en P. Falger voor zijn aantekeningen bij de summary.

En natuurlijk al diegenen die als respondent aan dit onderzoek hebben meegewerkt en de arbeidsorganisaties, die hen daartoe in staat hebben gesteld.

Maar tenslotte wil ik bovenal mijn ouders dankzeggen, die mijn studie hebben mogelijk gemaakt en die altijd een belangrijke bron van motivatie zijn geweest. 
$-234-$ 
De auteur van dit proefschrift werd op 5 december 1949 geboren te Oldenzaal. Na het behalen van zijn HBS-b diploma, aan de RK HBS "Marianum" te Groenlo in 1967, ging hif psychologie studeren aan de Katholleke Universiteit te Nijmegen. In okotober 1975 behaalde hij zijn doctoraalexamen psychologie, met als hoofdvak:

Godsdienst- en Kultuurpsychologie en als belangrijkste bijvak: Psychologie van arbeid en organisatie.

Sinds 1 april 1974 was hif als stafdocent sociale psychologie verbonden aan de School voor de Journalistiek te Utrecht. Vervolgens trad hij in augustus 1978 als cursusleider in dienst van het A.C. de Bruijn-instituut te Doorn (Scholings- en vormingsinstituut van het $\mathrm{NKV}$ ). En vanaf februari 1980 is hij werkzaam aan de Rijksuniversiteit Limburg. Hij behoort tot de capaciteitsgroep Medische Psychologie en is vanuit deze groep vooral werkzaam ten behoeve van de Algemene Faculteft, studierichting Soctale Gezondheldkunde. 